\title{
Intestinal development and inflammation : role of polyamines and nitric oxide
}

Citation for published version (APA):

ter Steege, J. C. A. (1998). Intestinal development and inflammation : role of polyamines and nitric oxide. [Doctoral Thesis, Maastricht University]. Febodruk b.v. https://doi.org/10.26481/dis.19981023js

Document status and date:

Published: 01/01/1998

DOI:

10.26481/dis.19981023js

Document Version:

Publisher's PDF, also known as Version of record

\section{Please check the document version of this publication:}

- A submitted manuscript is the version of the article upon submission and before peer-review. There can be important differences between the submitted version and the official published version of record.

People interested in the research are advised to contact the author for the final version of the publication, or visit the DOI to the publisher's website.

- The final author version and the galley proof are versions of the publication after peer review.

- The final published version features the final layout of the paper including the volume, issue and page numbers.

Link to publication

\footnotetext{
General rights rights.

- You may freely distribute the URL identifying the publication in the public portal. please follow below link for the End User Agreement:

www.umlib.nl/taverne-license

Take down policy

If you believe that this document breaches copyright please contact us at:

repository@maastrichtuniversity.nl

providing details and we will investigate your claim.
}

Copyright and moral rights for the publications made accessible in the public portal are retained by the authors and/or other copyright owners and it is a condition of accessing publications that users recognise and abide by the legal requirements associated with these

- Users may download and print one copy of any publication from the public portal for the purpose of private study or research.

- You may not further distribute the material or use it for any profit-making activity or commercial gain

If the publication is distributed under the terms of Article $25 \mathrm{fa}$ of the Dutch Copyright Act, indicated by the "Taverne" license above, 


\section{Intestinal development and inflammation Role of polyamines and nitric oxide}





\title{
Intestinal development and inflammation Role of polyamines and nitric oxide
}

\author{
PROEFSCHRIFT
}

ter verkrijging van de graad van doctor aan de Universiteit Maastricht, op gezag van de Rector Magnificus, Prof. dr. A.C. Nieuwenhuijzen Kruseman, volgens het besluit van het College van Decanen, in het openbaar te verdedigen op vrijdag 23 oktober 1998 om 12.00 uur

door

Jessica Catharina Anna ter Steege

geboren op 17 februari 1969

te Utrecht 
Promotor:

Prof. dr. R.A.M.G. Donckerwolcke

Co-promotores:

Dr. W.A. Buurman

Dr. P.Ph. Forget

\section{Beoordelingscommissie}

Prof. dr. E.F.M. Wouters (voorzitter)

Prof. dr. H.A. Büller (Erasmus Universiteit Rotterdan)

Prof. dr. G. Dandrifosse (University of Liège)

Prof. dr. P.B. Soeters

Prof. dr. R.W. Stockbruigger

ISBN: 90-9012021-1

NUGI: 743

Lay-out: K. Scheele, 's-Hertogenbosch

Onslag: G. van Zomeveld, Maastricht

Drukwerk: FEBODRUK bv

The financial support for publication of this thesis from Dr. J.H. van der Laar Stichting, Mead Johnson. Nutricia Nederiand B.Y. and SNS-bank Limburg is gratefully acknowledged. 
aan mijn ouders in herinmering aan $O m$ i 



\section{CONTENTS}

List of abbreviations

Preface

Chapter 1. Introduction and outline of the thesis

Chapter 2. The neonatal development of intraepithelial and lamina propria lymphocytes in the murine small intestine

Chapter 3. Spermine induces maturation of the immature intestinal immune system in neonatal mice

Chapter 4. Nitrotyrosine in plasma of coeliac disease patients as detected by a new sandwich ELISA

Chapter 5. Presence of inducible nitric oxide synthase, nitrotyrosine, CD68 and CD14 in the small intestine in coeliac disease

Chapter 6. The role of endogenous IFN- $\gamma$, TNF- $\alpha$, and IL-10 in LPSinduced nitric oxide release in a mouse model

Chapter 7. Regulation of LPS-induced iNOS expression in the major organs in a mouse model. Role of endogenous TNF- $\alpha$, IFN- $\gamma$ and IL-10

Chapter 8. The anti-inflammatory actions of polyamines are mediated by polyamine oxidase and are related to cytotoxicity

Chapter 9. Oral spermine administration inhibits NO-mediated intestinal damage and levels of systemic inflammatory mediators in a mouse endotoxin model

Chapter 10. General discussion

Chapter 11. Summary

Dankwoord

List of publications

Curriculum vitae 


\section{LIST OF ABBREVIATIONS}

\begin{tabular}{|c|c|c|}
\hline $\mathrm{ABC}$ & $=$ & avidin-biotin-peroxidase complex \\
\hline $\mathrm{AEC}$ & $=$ & amino-ethyllcarbazole \\
\hline $\mathrm{BCS}$ & $=$ & bovine calf serum \\
\hline BSA & $=$ & bovine serum albumin \\
\hline DAO & $=$ & diamine oxidase \\
\hline DFMO & $=$ & difluoromethylornithine \\
\hline ELISA & $=$ & enzyme linked immunosorbent assay \\
\hline eNOS & $=$ & endothelial nitric oxide synthase \\
\hline DTT: & $=$ & dithiothreitol \\
\hline HA & $=$ & hydroxylamine \\
\hline HS & $=$ & human serum \\
\hline IEL & $=$ & intraepithelial lymphocytes \\
\hline IFN- $\gamma$ & $=$ & interferon $-\gamma$ \\
\hline IL & $=$ & interleukin \\
\hline iNOS & $=$ & inducible nitric oxide synthase \\
\hline i.p. & $=$ & intraperitoneal \\
\hline IS & $=$ & isonicotinic acid \\
\hline i.v. & $=$ & intravascular \\
\hline KLH & $=$ & keyhole limpet hemocyanin \\
\hline LPB & $=$ & LPS binding protein \\
\hline LPL & $=$ & lamina propria lymphocytes \\
\hline L.PS & $=$ & lipopolysaccharide \\
\hline Mab & $=$ & monoclonal antibody \\
\hline MTT & $=$ & diphenyltetrazolium \\
\hline nNOS & $=$ & neural nitric oxide synthase \\
\hline NO & $=$ & nitric oxide \\
\hline $\mathrm{NO}_{\mathrm{x}}$ & $=$ & nitric oxide oxidation products (nitrite and nitrate) \\
\hline PAO & $=$ & polyamine oxidase \\
\hline PBS & $=$ & phosplhate buffered saline \\
\hline PBMCs & $=$ & peripheral blood mononuclear cells \\
\hline PHA & $=$ & phytohaemagglutinin \\
\hline PMNs & $=$ & polymorphonuclear leukocytes \\
\hline PP & $=$ & peyer's patches \\
\hline ODC & $=$ & ormithine decarboxylase \\
\hline r & $=$ & recombinant \\
\hline $\mathrm{RT}$ & $=$ & roomtemperature \\
\hline $\mathrm{s}$ & $=$ & soluble \\
\hline TCR & $=$ & T-cell receptor \\
\hline TMB & $=$ & tetramethylbenzidine \\
\hline TNF- $\alpha$ & $=$ & tumor necrosis factor $\alpha$ \\
\hline TNF-R55 & $=$ & TNF-receptor 55 \\
\hline TNF-R75 & $=$ & TNF-receptor 75 \\
\hline
\end{tabular}




\section{PREFACE}

Polyamines have been implicated in various aspects of the immune system. Whereas intracellular polyamines are essential for cell activation and proliferation, exogenous polyamines have been implicated to exert immunosuppressive effects.

Moreover, polyamines are involved in the metabolic route of the potent inflammatory mediator nitric oxide (NO). Both polyamines and $\mathrm{NO}$ are metabolized from the amino acid, L-arginine. L-arginine can be converted by NO synthase into NO and citrulline or by arginase into ornithine, the precursor of polyamine biosynthesis. Polyamines and NO are derived from the same precursor and both exert effects on the intestine. Whereas enhanced NO production is thought to be implicated in the intestinal damage observed during an inflammatory response in this organ, polyamines are required for intestinal repair. Intestinal inflammation as observed during an allergic reaction to food antigens or during systemic inflammation such as sepsis present an important clinical problem.

Therefore, in this thesis various aspects of polyamines and NO in relation with intestinal inflammation have been investigated. 
$-10$ 
CHAPTER 1

GENERAL INTRODUCTION AND OUTLINE OF THE THESIS 


\section{POLYAMINES}

\section{Origins and functions}

Polyamines are ubiquitous low-molecular-weight polycationic nonprotein nitrogenous bases that are present in virtually all cells (for reviews see refs 1-7). The four most common polyamines are cadaverine, putrescine, spermidine and spermine (Figure 1).

Spermine was the first polyamine to be discovered in 1678 by Antonie van Leeuwenhoek (8), however scientific research on these compounds was not conducted until 300 years later, after Herbst and Snell in 1949 observed that the polyamines spermidine and spermine were essential for the growth of certain microorganisms (9). The names of the polyamines spermidine and spermine, containing three and four amine groups respectively, refer to seminal fluid, from which these compounds were first isolated.

Figure 1 . The four most common polyamines

$$
\begin{gathered}
\mathrm{NH}_{2}\left(\mathrm{CH}_{2}\right)_{5} \mathrm{NH}_{2} \\
\text { cadaverine } \\
\mathrm{NH}_{2}\left(\mathrm{CH}_{2}\right)_{4} \mathrm{NH}_{2} \\
\text { putrescine } \\
\mathrm{NH}_{2}\left(\mathrm{CH}_{2}\right)_{3} \mathrm{NH}\left(\mathrm{CH}_{2}\right)_{4} \mathrm{NH}_{2} \\
\text { spermidine } \\
\mathrm{NH}_{2}\left(\mathrm{CH}_{2}\right)_{3} \mathrm{NH}\left(\mathrm{CH}_{2}\right)_{4} \mathrm{NH}\left(\mathrm{CH}_{2}\right)_{3} \mathrm{NH}_{2} \\
\text { spermine }
\end{gathered}
$$

Cadaverine ( 1,5 -diaminopentane) and putrescine (diaminobutane), which contain only two amine groups, were first isolated from decomposing animal material and were thought to be toxins. Their names originate from their smell, characteristic of putrefaction. In the literature the term polyamines usually also includes these diamines. In accordance, throughout this thesis the term polyamines includes the four amines described above (cadaverine, putrescine, spermidine and spermine), unless indicated otherwise.

Whereas prokaryotes mainly produce cadaverine, putrescine and spermidine, eukaryotes synthesize putrescine, spermidine and spermine (2). Polyamines are flexible polycations, since under physiological conditions they exhibit two, three or four positive charges and are able to rotate around the $\mathrm{C}-\mathrm{C}$ or $\mathrm{C}-\mathrm{N}$ bonds. They have a 
wide array of functions in cellular metabolism and are involved in DNA, RNA and protein synthesis (1-7). Because of their positive charge and flexibility polyamines bind tightly to nucleic acids, thereby neutralizing the negatively charged phosphate groups present in DNA and RNA which usually repel each other. Consequently, polyamines stabilize the secondary structure of the double helix of DNA, and protect the nucleic acids against thermal denaturation and enzymatic degradation $(5-6,10)$. Further, polyamines are able to bind covalently to proteins, thereby modifying proteins post-translationally (11).

\section{Polyamine biosynthesis}

Polyamine biosynthesis occurs in the cytoplasm of mammalian cells and is controlled by ornithine decarboxylase (ODC) activity $(\mathbb{1}-6,12-13)$. ODC is the rate limiting keyenzyme in polyamine biosynthesis and forms putrescine from the amino acid ornithine (Figure 2). Omithine is present in the plasma (14) and can also be produced within the cell by the action of arginase which forms ornithine from L-arginine (4). ODC is a highly regulated enzyme with control points at the level of transcription, translation and protein degradation (15). Spermidine is formed from putrescine by the addition of an aminopropyl group donated by decarboxylated S-adenosylmethionine, a reaction catalyzed by the aminopropyltransferase spermidine synthase. Addition of a second aminopropyl group to spermidine, catalyzed by spermine synthase, also an aminopropyltransferase, yields spermine (16). The source of the aminopropyl groups is $\mathrm{S}$-adenosylmethionine which is decarboxylated by $\mathrm{S}$-adenosylmethionine decarboxylase. The synthesis of spermidine and spermine is dependent on the availability of the aminopropyl donor. Therefore, next to ODC activity, S-adenosylmethionine decarboxylation may also be a rate-limiting step in polyamine biosynthesis (2).

In mammalian cells spermine and spermidine can be converted back to putrescine (Figure 2) $(2,17)$. The first step is the acetylation of an aminopropyl group of spermine or spermidine, catalyzed by the enzyme spermine/spermidine $N^{1}$ acetyltransferase, giving $N^{\prime}$-acetyl spermine or spermidine. These compounds are in turn degraded by by intracellular polyamine oxidase (PAO) with the formation of spermidine or putrescine and an aldehyde (3-acetamidopropanal), respectively. Aldehyde dehydrogenase will transform the aldehyde into $B$-alanine. Putrescine can then be recycled and used again for the formation of spermidine and spermine $(2,17)$. Degradation of spermine and spermidine to putrescine possibly represents a physiological mechanism to prevent spermine accumulation in cells. A third enzyme involved in the regulation of polyamine biosynthesis is diamine oxidase (DAO) (17, 18). DAO degrades putrescine and thereby controls the amount of putrescine available for polyamine synthesis. Furthermore, pollyamines exert an efficient negative feedback control on their own synthesis (13). 
Figure 2. A simplified figure of the role of intracellular $P A O(A)$ and serum $P A O(B)$ in the polyamine biosynthesis and conversion pathways $(B)$. The mumbers correspond to the enzymes involved, 1 =arginase, 2=ornithine decarboxylase, 3=spermidine synthase, $4=$ spermine synthase, $5=$ spermine/spermidine $N^{\prime}$-acetyltansferase, $6=$ intracellular polyamine oxidase, $7=$ aldehyde dehydrogenase, 8 -diamine oxidase, $9=$ serum polyamine oxidase, $10=\beta$ elamination; spantaneous reaction.
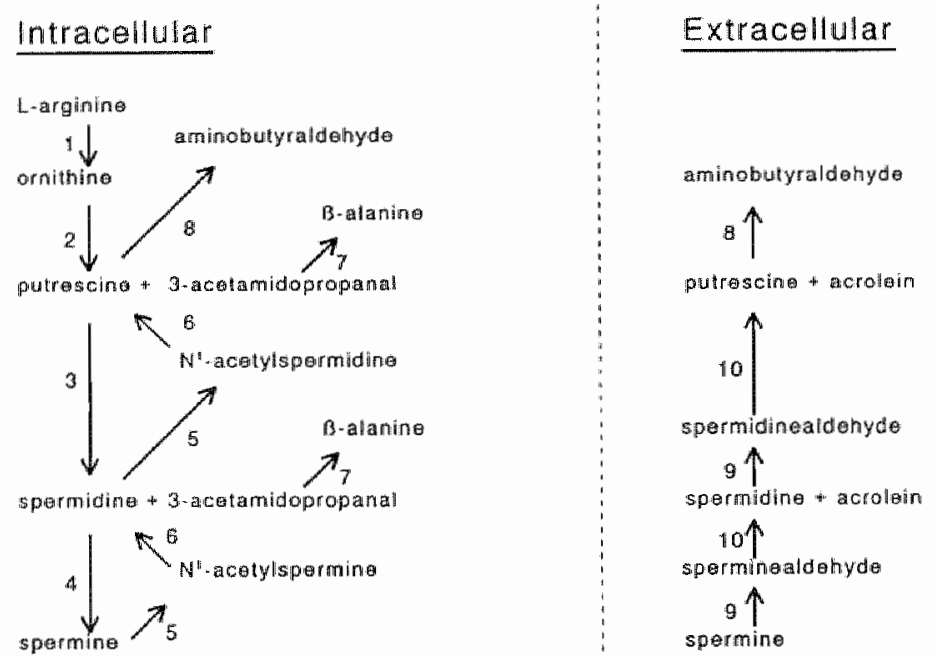

The concentration of polyamines present in the cell depends on the metabolic condition of the cell, i.e. the higher the metabolic activity of the cell the higher the amount of polyamines. Increases in DNA, RNA and protein synthesis are preceded by increases in ODC activity and consequently enhanced polyamine biosynthesis (1-7). In vitro studies with difluoromethylornithine (DFMO), an inhibitor of polyamine biosynthesis that irreversibly inhibits ODC activity, revealed that depletion of intracellular polyamine levels results in a decrease in protein and DNA synthesis and consequently in a reduction of cellular proliferation $(19,20)$. These findings indeed confirmed that polyamines are essential for normal, physiological cell functioning.

\section{Polyamine uptake}

It was previously believed that cellular polyamine biosynthesis was the only pathway to make polyamines available for cellular processes (21). However, since exogenous addition of polyamines to cells cultured in the presence of DFMO has been shown to abrogate the negative effects of DFMO on cell growth, it is clear that mammalian cells regulate their polyamine content by two different pathways. The first pathway involves cellular synthesis and interconversion, and the second pathway involves 
transmembrane uptake from the extracellular compartment $(4,22)$. The mechanisms by which cells can take up and use extracellular polyamines are not completely understood. Nevertheless, the presence of specific polyamine transport systems has been described for a wide range of mammalian cells (21). The physiological significance of the transport system is obvious from the finding that cellular uptake of polyamines is upregulated during inhibition of endogenous polyamine biosynthesis (23) and during the exponential phase of cell growth (24). In line with this, cancer research has revealed that tumor cells utilize the polyamine uptake system as a rescue mechanism to bypass polyamine deficiency induced by polyamine biosynthesis inhibitors $(25,26)$.

High levels of polyamines are found in the intestinal lumen (27). Euther the diet, gut bacteria or extruded enterocytes can be the source of intra-luminal polyamines. Using isolated rat enterocytes and enterocyte cell line cultures on permeable filters, it was shown that enterocytes are able to transport polyamines from the apical side to the basolateral side $(28,29)$. These studies are supported by in vivo studies using orally administered ${ }^{14} \mathrm{C}$-labelled polyamines, which revealed that the uptake of polyamines by the small intestine was linearly dependent on the total input (30). One hour after gastric administration only $11-15 \%$ of the labeled putrescine could be detected as the original polyamine. Taking conversion of putrescine to higher polyamines into account, $29-39 \%$ of the labeled putrescine was recovered. A small part was found in small intestinal tissue and the main part was taken up systemically. These data indicate that putrescine is largely metabolized, probably by $\mathrm{DAO}$ which is abundantly present in the intestinal tissue $(31,32)$. In contrast to putrescine, spermidine and spermidine were better conserved, i.e. about $80 \%$ of labeled spermidine and about $73 \%$ of spermine were detected in their original form. Taking conversion to other polyamines into account, $87-96 \%$ of spermidine and $85-93 \%$ of spermine was recovered (30). Further, these studies revealed that the radioactively labeled polyamines were absorbed from the intestinal lumen, released into the systemic circulation and distributed to various tissues according to their metabolic activity, i.e. the higher the tissue metabolic activity, the higher polyamine uptake $(27,30,33)$ Polyamines absorbed from the gastrointestinal tract seem to play an essential role in the maintenance of an adequate polyamine pool in the body (34). The importance of this polyamine pool for intestinal development, intestinal function and the (mucosal) immune system will be discussed below.

\section{INTESTINAL DEVELOPMENT}

\section{Development of the intestinal mucosa}

The general pattern of intestinal development is similar in all mammals (35). Many brush border properties are different in neonatal animals as compared to adults. For 
example, in most mammalian neonates macromolecules such as immunoglobulin can be transported across the intestinal epithelium into the circulation. The physiological function is probably associated with the transfer of passive immunity $(35,36)$. Intestinal maturation is characterized by a decline in intestinal permeability for these macromolecules $(35,36)$. In rodents most maturation changes occur during the third week of life, which corresponds to the weaning period. In general, the properties of the postweaning intestine are similar to those of the adult intestine. At weaning, the gastrointestinal tract undergoes substantial modifications which affect its structural and functional characteristics.

Between birth and day 1.6, crypt cell division occurs at a low rate in rats and mice. The enterocytes contain large supranuclear vacuoles (37) and exhibit high lactase activity, which is essential for the digestion of milk lactose $(35,38)$. During the third and fourth week after birth, crypt cell proliferation increases in the small intestinal epithelium and is even more rapid than in the adult (39). In parallel, with the increase in cell proliferation the large supra-nuclear vacuoles in the immature enterocytes disappear (37) and the mucosal brushborder enzyme activity adapts to the weaning diet by a decrease in lactase activity and an increase in maltase and sucrase activity, essential for the digestion of solid food carbohydrates $(35,38)$.

Although intestinal maturation in neonates has been the subject of intensive study, the triggers for the major biochemical and morphological changes during maturation are still poorly understood $(40,41)$. Intestinal maturation seems to be partly regulated by internal triggers and partly by external triggers such the change in food intake from milk to solid food $(40,42-44)$. As an example of the former, the time point of postnatal increase in sucrase activity has been shown to be independent of prolonged suckling. Further, the sucrase activity of an intestinal graft under the skin of a host younger than the donor will increase at the postnatal age of 18 days of the donor tissue independent of the age of the host (45). Similarly, in bypassed intestinal loops sucrase activity increases the 18th postnatal day. Likewise, removal of the pituitary, adrenal or thyroid gland in rats does not influence the timepoint of increase in sucrase activity. Together these observations suggest that the timepoint of increase in sucrase activity is regulated by an "internal clock" and is not influenced by both food antigens or hormones $(40,46)$. However, the level of sucrase activity reached in the fourth postnatal week is dependent on the change in diet. This is illustrated by the fact that sucrase activity in unweaned animals is upregulated to only $50 \%$ of the level observed in weaned animals (47). Similarly, several studies have indicated that, in contrast to the increase in sucrase activity, the time point of the decrease in lactase activity is dependent on dietary changes at the time of weaning $(40,43)$. For example, prolonged suckling delays the decrease in lactase activity (48). Likewise, lactase activity in intestinal grafts placed under the skin of a younger host will only decline after weaning of the host (45). 


\section{Polyamines and mucosal maturation}

An increase in intestinal ODC activity and consequently of polyamine concentrations is another striking characteristic of intestinal maturation during weaning. The importance of ODC activity and polyamine biosynthesis for intestinal development has been underscored by studies of various investigators. Luk et al. (41) and Alarcon et al. (49) revealed that inhibition of intestinal ODC activity by DFMO treatment, prevents the normal increase of polyamine concentrations in the intestinal mucosa at weaning. In parallel, the development of maturation characteristics such as the increase in brush border maltase activity was prevented by DFMO, indeed suggesting a relation between polyamine biosynthesis and intestinal maturation $(41,49)$. In addition, delayed postnatal intestinal maturation is observed in the relatively ODCdeficient sparse-fur mouse (50). Interestingly, exogenous administration of insulin (18, 51) or epidermal growth factor EGF (52-54) induces an increase intestinal ODC activity which is paralleled by precocious intestinal maturation of the intestine, suggesting that increased intestinal polyamine synthesis might be involved in insulinor EGF-mediated intestinal maturation. A relation between polyamines and intestinal maturation is supported by the observation that oral administration of the polyamines spermidine and spermine to neonatal rodents triggers precocious biochemical, morphological and functional maturation of the small intestine $(36,55-58)$. The exact mechanisms by which polyamines affect intestinal maturation still have to be elucidated. In contrast to oral spermine administration, intraperitoneal (i.p.) or intravascular (i.v.) administration of spermine does not affect intestinal maturation $(59,60)$. Interestingly, oral spermine administration induces the release of adrenocorticotrophin (ATCH) and glucocorticosteroids $(57,59,61)$, hormones which are essential for intestinal maturation $(62,63)$ whereas i.p. or i.v. spermine administration has no effect on the release of these hormones (60). These observations suggest a link between oral spermine administration and the pituitary-adrenal axis. In line with this, adrenalectomy abrogates the effect of oral spermine administration on lactase specific activity. However, a direct effect of polyamines on the enterocyte should not be excluded since adrenalectomy does not completely eliminate the spermine-induced increase in sucrase and maltase activity (57). Moreover, it has been shown that polyamines can act directly on gene expression at both transcriptional as well as posttranslational levels $(1-6,11,13)$.

\section{Intestinal immune system}

The intestinal immune system also called the gut associated lymphoid tissue (GALT) consists of three distinct compartments which contain lymphocytes unique to this mucosal site: the Peyer's patches (PP), the lamina propria and the epithelium (for reviews see ref 64-68). The PP are aggregates of lymphoid follicles, separated from the intestinal lumen by specialized epithelial cells, the so-called $M$ cells (69). The 
lamina propria contains diffusely distributed lymphocytes, the so called lamina propria lymphocytes (LPL). In the intestinal epithelium, the lymphocytes present between the epithelial cells are the intraepithelial lymphocytes (IEL).

There are distinct differences in phenotype and function between the lymphocytes in the epithelium and in the lamina propria. LPL are phenotypically and functionally similar to PP and peripheral lymphocytes (70). Similarly to peripheral blood lymphocytes, $L P L$ consist mainly of $\mathrm{CD}^{+}$(helper) cells, whereas most of the IEL are of the $\mathrm{CD} 8^{*}$ (cytotoxic/suppressor) phenotype (65).

IEL are present in an unusual immunological micro-environment in the sense that they are located in the epithelium between enterocytes, separated from the gut lumen by tight junctions between epithelial cells and from the lamina propria by the basal membrane. Interestingly, the intestinal epithelium shares with the thymic epithelium the same endodermic origin. Furthermore, it has been demonstrated that intestinal epithelial cells, like thymus epithelial cells, express MHC class II antigens in the absence of inflammation, suggesting that enterocytes act as antigen presenting cells for IEL $(71,72)$. This thymic analogy can even be extended further, as animal studies have indicated that substantial numbers of IEL mature extrathymically in the intestine $(42,44,67,73-75)$.

An adequate enteric mucosal immune system is important as a first line of immunological defense $(64,68)$. A wide variety of antigens, such as bacteria, viruses, parasites and food, all of which will provoke a different immune response, may be present in the intestinal lumen. While a limited protective immune response to potential pathogens is necessary, a deleterious inflammatory response to foreign dietary antigens must be suppressed. Normally the immune response to food antigens will not result in manifest intestinal inflammation. In contrast, in the case of food allergy such an immune response may result in severe clinical manifest inflammation. Consequently, in the intestine, perhaps more than in any other organ, immune reactivity must be tightly regullated (68). The question as to how the mucosal immune system categorizes antigens and selects a particular response is central to this process but remains largely unanswered $(68,69)$. However, the solution to this question is likely to hold the key for the prevention and control of pathological intestinal inflammation as observed in food intolerance, e.g. cow's milk intolerance and coeliac disease, and other inflammatory bowel disorders, including Crohn's disease and ulcerative colitis.

\section{Development of the intestinal immune system}

The newborn's gastrointestinal tract has to adapt to a variety of antigenic (food) substances and microbial organisms and must develop a mucosal barrier against penetration of these antigens (68). The observation that the risk of developing hypersensitivity reactions of the immediate or delayed type is increased in children in comparison with adults, suggests that developmental factors are likely to play an 
important, and as yet poorly understood, role in the development of food-sensitive enteropathies (68).

At weaning, the intestinal immune system undergoes alterations in parallel with the biochemical and morphological maturation. The number of intestinal lymphocytes, both IEL and LPL, increases. The number of lymphocytes present in the intestine at birth is approximately $10 \%$ of the number found in adult animals $(76,77)$. Further, FACS analysis of $\mathrm{CD}^{+} \mathrm{IEL}$ and LPL has indicated that in rodents the major increase in $\mathrm{CD}^{+} \mathrm{T}$ cells in both the lamina propria and the epithelium occurs between the first and $28^{\text {th }}$ postnatal day (78). Similarly to biochemical maturation, is immunological maturation also regulated by internal as well as external triggers. For example, the increase of $T C R \gamma \delta^{+}, C D 8^{+}$thymus-independent IEL starts before weaning and is therefore at least partly independent of the change of diet. In contrast, the increase of TCR $\alpha B^{+}, \mathrm{CD}^{+}$and $\mathrm{CDS}^{+}$thymus-dependent lymphocytes is particularly stimulated by the change of diet occurring at weaning, since the increase of these cells occurs only after weaning and has shown to be delayed by prolonged weaning $(42,77,79,80)$.

\section{POLYAMINES AND NITRIC OXIDE IN THE MATURE INTESTINE}

\section{Polyamines and mucosal integrity}

Several reports have indicated that polyamines play a central role in the development and regulation of hypo- and hyperplasia of the epithelium in the mature intestine. In mammals, the gut epithelium has the highest cell turn over rate and hence, the highest metabolic activity of the body (12). The intestinal lining of mammals is renewed every 2-3 days and the newly formed cells have to differentiate and mature in order to fulfill their digestive and absorptive functions properly. When compared to most other tissues, mucosal ODC in the small intestine shows a high basal activity when compared to most other tissues (2). ODC activity is present in cells of the villus as well as in proliferating crypt cells, suggesting that polyamines participate in intestinal celll differentiation as well as proliferation (81).

The notion that polyamines are essential for the maintenance of intestinal integrity is derived from studies in which oral administration of DFMO was shown to cause depletion of intestinal polyamines, paralleled by villus atrophy $(49,82,83)$.

Furthermore, polyamines have been shown to play a role in the maintenance of mitochondrial integrity in maturing enterocytes (84). As enterocytes migrate along the villus, mitochondrial function and polyamine concentration in these cells increase in order to handle the increased metabolic demands placed on the cell by nutrient absorption (84). DFMO treatment has been demonstrated to clisrupt mitochondrial function and is consequently cytotoxic for enterocytes. The effect of DFMO treatment on the intestine can be reversed by exogenous (oral) polyamine administration (83). Moreover, polyamine administration without DFMO treatment increases the rate of 
mucosal growth, as determined by an increase in mucosal DNA, RNA and protein concentrations in the small intestine, substantiating that under normal conditions polyamines are important stimulants of gastrointestinal mucosal growth in adult rats (83).

ODC activity and polyamine synthesis are enhanced when metabolic activity is increased. Consequently, ODC activity is enhanced during feeding and declines when intestinal metabolic activity decreases for example during fasting $(21,85)$ or during parenteral nutrition $(86,87)$. The decrease in polyamine levels during fasting is a result of reduced synthesis due to a decrease in ODC activity and of increased degradation due to an increase in diamine oxidase (DAO) activity. DAO metabolizes putrescine and thereby prevents its use in polyamine biosynthesis. The reverse occurs during refeeding, i.e. ODC increases and DAO decreases $(21,88)$. It is often assumed that the enhanced ODC activity is the principal mechanism of endogenous putrescine accumulation and subsequent polyamine synthesis. However, it is conceivable that diminished putrescine catabolism, as a result of reduced DAO activity $(89,90)$ may be as important in putrescine accumulation and in the stimulation of tissue growth, as enhanced putrescine synthesis resulting from increased ODC activity. The relative contributions of these reciprocative enzyme activities in polyamine metabolism remain to be established (91). DAO is synthesized in mature enterocytes and therefore mucosal DAO activity migth reflect the presence of mature enterocytes (92). DAO activity is also measurable in serum. In rat a possible correlation exists between plasma and intestinal DAO activity, suggesting that serum DAO activity reflects the total mass of mature entrocytes and consequently can be used as a marker for intestinal integrity (92). Further, in human a correlation between mucosal DAO activity and disaccharidase activity has been found suggesting a relation between DAO activity and enterocyte function (93). It has been estimated that, except during pregnancy, 95\% or more of the total body stores of DAO are located in the intestinal mucosa $(92,94)$, suggesting an important role for DAO in the regulation of intestinal polyamine metabolism. Although DAO is synthesized by enterocytes, approximately $66 \%$ of the total amount of DAO is translocated to the lamina propria where it is bound to endothelial cells of the capillaries (95). At this location DAO might prevent leakage of diamines from the intestine into the circulation (95). DAO might also play a role in the regulation of extracellular putrescine levels and thereby control the amount of putrescine available for uptake by intestinal cells.

As described earlier, intestinal epithelial ODC activity and luminal transport of polyamines to the intracellular compartments contribute to intestinal polyamine accumulation. However, Pusztai et al. (96) have suggested yet another source of polyamines. They showed that oral administration of phytohaemagglutinin (PHA), a kidney bean lectin, induced intestinal hyperplastic growth and accumulation of large amounts of polyamines in the intestinal tissue without a major increase in ODC activity. The observation that DFMO treatment does not prevent PHA-induced intestinal growth, confirms that ODC induction is not essential for intestinal 
polyamine accumulation in this setting (97). Using the same animal model, $B$ ardocz et al. (98) demonstrated that apical epithelial cell uptake of intraluminal polyamines was not enhanced after oral PHA administration. In contrast, the basolateral uptake of polyamines from the circulation was found to be enhanced after oral PHA administration $(98,99)$. At the same time PHA administration reduced intestinal DAO activity resulting in decreased polyamine degradation (100). Together, increased basolateral uptake and reduced degradation of polyanines, result in intestinal polyamine accumulation after PHA administration. Since under normal conditions the systemic concentrations of polyamines are not sufficient to account for the high levels of intestinal polyamines observed after PHA stimulation, Pusztai and Bardocz suggested that polyamines can be mobilized from body stores and transported to the site where needed $(99,101)$. The mainienance of the total polyamine pool is dependent of polyamines derived from exogenous sources as well as of those derived from de novo synthesis $(12,30,33)$.

\section{Polyamines and intestinal inflammation}

Conditions that are characterized by intestinal mucosal damage, such as waterimmersion-induced stress in rats (102), infection (103), ischemia-reperfusion (104, $105)$, burn injury $(106)$, sepsis $(106,107)$ and inflammatory diseases $(91)$ are all accompanied by increased intestinal ODC activity and increased intestinal polyamine levels, suggesting that polyamines are essential for repair of mucosal injury. Moreover, during intestinal adaptation in response to jejunectomy intestinal ODC activity and polyamine content are increased in parallel with the increase in cell proliferation $(91,108)$. Oral DFMO administration prevents this increase in ODC activity and polyamine levels and abrogates intestinal adaptation in this rat model (83, 108). In contrast, administration of aminoguanidine, which blocks DAO activity (89, $90)$, has been shown to increase intestinal putrescine concentrations and at the same time to enhance intestinal adaptation after jejunectomy in rats.

Intestinal damage and inflammation is, next to increased ODC activity, often associated with elevated intestinal concentrations of inflammatory mediators such as the cytokines TNF- $\alpha, \mathbb{I L}-1$ and IL-6 $(109,110)$. Particularly the pro-inflammatory cytokines TNF- $\alpha$ and $\mathrm{LL}-1$ seem to be involved in the upregulation of intestinal protein synthesis, since intraperitoneal injection of recombinant TNF- $\alpha$ or IL-1 enhanced intestinal protein synthesis in mice (111). Moreover, it was demonstrated that $I L-1$ is responsible for the upregulation of intestinal ODC activity and increase in intestinal putrescine and spermidine levels (112, 113).

Polyamines stimulate mucosal repair by activation of tissue transglutaminase activity which is predominantly present in enterocytes $(\mathbb{1 1 4}, 115)$. Tissue transglutaminase catalyzes cross-linking of proteins and uses polyamines as substrate (116). Transglutaminase activity is required for migration of intestinal epithelial cells in vitro (117) and for the maintenance of enterocyte adhesion to the basal membrane 
and for enterocyte proliferation in vivo (116). Inhibition of enterocytic polyamine biosynthesis decreases transglutaminase activity, i.e. protein crosslinking, and consequently reduces binding of the enterocytes to the extracellular matrix $(114,118)$. The importance of transglutaminase activity in mucosal repair is supported by the observation that administration of dansylcadaverine, a specific inhibitor of protein cross-linking, to DFMO-treated rats not only prevents transglutaminase activity but also decreases mucosal repair (115). The observation that this effect cannot be reversed by addition of exogenous polyamines supports the idea that polyamines induce mucosal repair by stimulation of transglutaminase activity (113). In conclusion, these observations show that similar to the neonatal intestine, the mature intestine is also largely dependent on polyamines for normal intestinal function and particularly for intestinal repair.

\section{NO and intestinal function}

Generally, NO can be synthesized from L-arginine by three different enzymes. Under basal, physiological conditions, $\mathrm{NO}$ is formed by two constitutively expressed isoforms of NO synthase (NOS). These two enzymes are commonly referred to as neural and endothelial NOS (nNOS and eNOS, respectively), named after the cell types initially found to express them. Both constitutive enzymes are dependent on calcium $\left(\mathrm{Ca}^{2+}\right)$ influx and produce a constant low amount of NO which is necessary for normal physiological functions $(119,120)$. Nitric oxide synthesized by eNOS and nNOS has been demonstrated to protect the intestine by inhibiting leukocyte adherence (121) and maintaining splanchnic blood flow $(122,123)$. Neural NOS derived NO seems to play a role in normal intestinal mobility which is illustrated by the fact that mobility disorders such as Hirschsprung's disease (124) and hypertrophic pyloric stenosis (125) are associated with lack of nNOS activity.

\section{NO and intestinal inflammation}

In contrast to both constitutive NOS, the inducible enzyme iNOS is independent of $\mathrm{Ca}^{2+}$ influx and is generally believed to be responsible for the highly elevated NO production during inflammation. The quiescent iNOS gene is only activated in states of severe immune activation (120). Although the ability of the gut to express iNOS may be of importance for cytotoxic protection, elevated production of NO is not without potential complications such as increased intestinal permeability $(126,127)$ with possible subsequent bacterial translocation $(128,129)$. Elevated local NO production has been reported to occur during intestinal inflammation in various animals models (130-133) as well as in man $(134,135)$.

Similarly to ODC activity, iNOS activity is induced by pro-inflammatory mediators such as cytokines $(136,137)$. Several in vitro studies indicated that particularly IFN- $\gamma$, TNF- $\alpha$, and IL-1 are involved in the regulation of enhanced NO production after 
endotoxin stimulation (120). For example, the presence of IFN- $\gamma$ is essential for the production and release of NO by most macrophage-like cells after endotoxin challenge (138). Furthermore, IFN- $\gamma$ has been shown to fully mediate IL-12 induced NO release (139). The role of TNF $\alpha$ in the regulation of NO release by macrophages is less clear, since some groups reported that anti-TNF- $\alpha$ treatment inhibits NO release $(140,141)$ whereas others reported that anti-TNF- $\alpha$ has no effect on NO release by a murine macrophage cell line $(141,142)$. Pretreatment of rodents with antibodies to TNF- $\alpha$ and $I L-1$ before LPS challenge has indicated that these cytokines, besides regulating polyamine synthesis, are also involved in the control of NO synthesis in vivo (120, 137).

Mechanisms of NO toxicity involve the interaction of NO with superoxide (143). This is illustrated by studies in which NO donors did not induce damage to epithelial or endothelial cells, unless a superoxide-generating hypoxanthine/xanthine oxidase system was added (144). Nitric oxide reacts with superoxide to form peroxynitrite which is a very potent oxidant (145-148). Peroxynitrite is highly cytotoxic due to its ability to oxidize sulfhydryl groups, lipids, proteins, enzymes and DNA (144, 145, 149). Moreover, evidence that peroxynitrite can destroy the gastrointestinal epithelium and induce severe colonic inflammation was provided by Rachmilewitz et al. (150), who showed that intrarectal peroxynitrite administration induced severe mucosal inflammation. Because of its strong reactivity resulting in a short half-life, peroxynitrite cannot be measured directly in vivo. However, peroxynitrite modifies tyrosine residues in proteins to form nitrotyrosine which is a stable product and can be detected immunohistochemically $(147,148)$. Inhibition of NO production prevents nitrotyrosine formation illustrating that NO production is essential for nitrotyrosine formation $(133,147)$. Thus, nitrotyrosine is a marker of NO and superoxide formation in vivo.

\section{Polyamines and nitric oxide}

As mentioned before, $\mathrm{NO}$ is formed from $\mathrm{L}$-arginine by the enzyme nitric oxide synthase. L-arginine can also be converted into ornithine by the enzyme arginase and in this way be used as a precursor for polyamine biosynthesis (Figure 3) (88). Although both polyamine biosynthesis and NO production have shown to be stimulated by pro-inflammatory cytokines, the control mechanisms that direct the use of arginine for either polyamine biosynthesis, i.e. stimulate arginase activity, or NO production, i.e. enhance NOS activity, in response to various stimuli are still unclear. Several studies indicated that polyamines can affect NO synthesis and vice versa. For example, it has been shown that polyamines inhibit NO production through inhibition of the induction of iNOS activity in LPS-stimulated murine macrophage cell line (151153). Spermine has been demonstrated to inhibit iNOS activity in the rat cerebellum (154). Further, it has been demonstrated that NO production by the enterocyte-like cell line HT-29 inhibits putrescine synthesis via inhibition of ODC activity in these cells 
(155). These observations suggest a reciprocal regulation of both compounds. Therefore, it is conceivable that the balance between polyamine and NO synthesis influences mucosal integrity and determines the extent of inflammatory intestinal damage.

Figure 3. Larginine is a precursor for both NO synthesis and ornithine biosynthesis. The numbers correspond to the enzymes involved; $1=$ nitric oxide synthase, $2=$ arginase

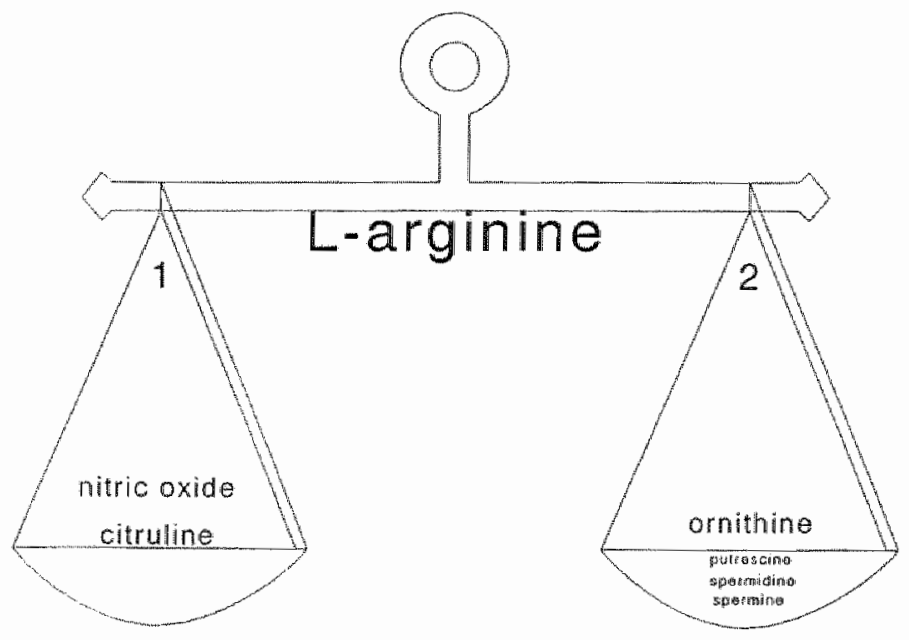

\section{Intestinal inflammation in coeliac disease}

Coeliac disease is a gluten-induced small bowel enteropathy that occurs in genetically susceptible individuals and is characterized by severe intestinal inflammation accompanied by enhanced intestinal metabolic activity and increased intestinal permeability. The small intestine of coeliac disease patients exhibits villous atrophy, crypt cell hyperplasia, infiltration of the lamina propria with lymphocytes, macrophages and plasma cells, and epithelial lymphocyte infiltration, all characteristics of severe inflammation (156-159). Besides increased serum levels of anti-gliadin antibodies, elevated levels of anti-endomysium antibodies are present in coeliac disease patients $(160,161)$, suggesting that next to the gluten peptide gliadin, another antigen, recognized by the anti-endomysium antibodies, is involved in the pathophysiology of coeliac disease.

The binding of gliadin to the mucosa with subsequent endocytosis and transport of gliadin to lysosomes is presumably an early event in gliadin toxicity $(162,163)$. Alternatively, an immunological reaction to gliadin fragments might occur (156-159) as a result of abnomal permeability of the intestinal mucosa $(164,165)$. Both of these 
hypotheses assume a selective binding of gliadin to cell surfaces. It has been suggested that gliadin can act as a lectin and bind to glycoproteins on enterocytes $(166,167)$. The demonstration that gliadin, similarly to polyamines, can be used as substrate for transglutaminase, present in enterocytes, could implicate a role of transglutaminase in the binding of gliadin to intestinal tissue (168). Interestingly transglutaminase is clearly enhanced in the intestine of patients with active coeliac disease as well as in patients in remission (168) and has recently been identified as the antigen recognized by anti-endomysium antibodies (169), which migth indicate a role of transglutaminase in the pathogenesis of coeliac disease.

The elevated expression of mRNA for several cytokines such as TNF- $\alpha, \| L-1$, IL-6, IL-2, IL-8, and monocyte chemoattractant protein-1 in the small intestine of untreated coeliac disease subjects points to the involvement of cytokines in the pathophysiology of this disease $(170,171)$. Of these cytokines, elevated production of IFN- $\gamma$ in the small intestine is considered most characteristic for coeliac disease (172174). Przemioslo et al. (174) demonstrated that the gliadin-induced histologica! changes in the small bowel mucosa can be prevented by anti-IFN- $\gamma$ antibodies, indicating that enhanced IFN- $\gamma$ production as observed in this condition is involved in the characteristic intestinal damage which occurs after a gluten challenge. Moreover, in vitro studies have shown that the increase in epithelial permeability induced by IFN- $\gamma$ is mediated by NO $(175,176)$ suggesting that intestinal NO production is increased in coeliac disease patients.

Further, in vitro experiments have demonstrated that IFN- $\gamma$ enhances the binding of gliadin to an intestinal epithelial cell line (177). Binding of food peptides such as gliadin to enterocytes may represent an important step in the initiation of food allergy. The binding capacity of the enterocyte cell membrane might determine the amount of food antigens delivered to intestinal lymphocytes. Furthermore, elevated levels of IFN- $\gamma$ have been shown to enhance MHC class II expression on enterocytes, which is even more upregulated in the presence of gliadin (178). Increased MHC class II expression will result in an elevation of antigen presentation to $\mathbb{E L L}$, resulting in increased stimulation of these cells to produce IFN- $\gamma$ and thereby initiating a vicious circle.

Because of the ethical problems of performing experiments with human in vivo, several in witro models have been developed to investigate the pathophysiology of coeliac disease. Culturing small intestinal biopsy tissue of coeliac disease patients is one of these models $(179,180)$. Intestinal biopsy tissues show morphological and biochemical recovery when cultured in gliadin-free medium in contrast to biopsy tissue cultured in the presence of gliadin (179-185). Another model is the culture of K562 (S) cells, a human myelogenous leukemia cell line, in the presence of gliadin. These cells normally grow as single cells, however, in the presence of gliadin they agglutinate. The toxic effect of gluten peptides in vitro as well as in vivo appears to correlate well with their capacity to induce agglutination of $\mathrm{K} 562$ (S) cells (185). A third model to examine the pathophysiology of coeliac disease is the in vitro culture of 
foetal rat small intestine, in the presence of gliadin. Gliadin inhibits the development of the foetal rat intestine and even induces degeneration of the intestinal tissue (184, 186). Interestingly, addition of polyamines, particularly spermidine, prevents gliadininduced cellular damage in these three coeliac disease models (187). It could be hypothesized, therefore, that polyamines inhibit gliadin-induced intestinal damage in coeliac disease patients, by competition with gliadin as substrate for transglutaminase. However, the exact mechanisms whereby polyamines prevent gliadin-induced tissue damage are still unclear.

Both intestinal and serum DAO activity are decreased in patients with untreated coeliac disease indicating a decrease in the number of enterocytes and therefore reflecting enhanced intestinal permeability, i.e. decreased mucosal integity, and a reduction in putrescine degradation $(91,188,189)$. The DAO activity returns to normal levels when a patient is on a gluten-free diet, indicating that intestinal integrity recovers when the patients are on a gluten free diet $(91,188)$.

\section{Intestinal inflammation in sepsis}

The important role of the intestine as a participant in the metabolic response to sepsis and other critical illnesses has been increasingly recognized during recent years (126). Several studies indicate that protein synthesis and polyamine synthesis are increased in the intestinal mucosa during sepsis (107, 111, 190-192). Interestingly, urinary excretion of polyamine degradation products is increased in septic patients, a finding that may reflect increased metabolic activity and an increased polyamine turnover in these patients (193). Next to increased intestinal ODC activity, increased ODC activity has also been observed in several other organs such as the liver, lung, spleen, kidney, brain and thymus after endotoxin challenge in rodents (1.94).

From a clinical perspective, changes in intestinal protein turnover during sepsis and other critical illnesses are important for several reasons. The high protein synthesis rate in the gut mucosa may significantly influence whole body protein balance. Furthermore, the intestine is the production site of a number of proteins with important biological functions, including gut hormones, digestive enzymes and cytokines. Therefore, dysregulation of the synthesis of these proteins can have several systemic effects $(195,196)$.

Next to the release of various pro-inflammatory cytokines $(109,110)$ of which TNF- $\alpha$ and IL- 1 have been shown to play a role in the enhanced protein metabolism observed during sepsis (see 1.3.2 polyamines and intestinal damage), enhanced NO production has been implicated in the pathogenesis of endotoxic shock in various animal models (197-200) as well as in human septic shock (201-203). Experimental endotoxemia leads to accumulation of nitrite and nitrate, stable end-products of NO synthesis, in urine and blood. As discussed before, NO is one of the most important mediators of gastrointestinal defence, influencing virtually every component of the mucosal defence network (144). The supra-physiological amounts of NO induced by 
cytokines and endotoxin have shown to mediate sepsis-induced intestinal damage, probably by peroxynitrite formation $(204,205)$. Since polyamines are essential for mucosal repair and inhibit endotoxin-induced NO release in witro, one might speculate that oral polyamine administration can inhibit sepsis-induced intestinal damage by stimulation of intestinal repair, inhibition of intestinal NO production and by inhibition of the release of pro-inflammatory cytokines.

\section{POLYAMINES AND (MUCOSAL) MMMUNE FUNCTION}

High concentrations of polyamines are found in cancer and foetal tissue as well as in seminal fluid. These tissues and fluids provoke antigenic challenges that generally do not elicit an immune response of the host organism, suggesting a possible immunosuppressive role of polyamines $(1,206)$. Nevertheless, the observation that DFMO inhibits proliferation of stimulated peripheral blood lymphocytes in human and in animall models points to the fact that a certain amount of polyamines is needed for pro-inflammatory cellular proliferation (207-211). Likewise, polyamines are believed to be involved in the regulation of the intestinal immune system. Difluoromethylornithine (DFMO) treatment of LPL inhibits con-A induced proliferation, ODC activity and DNA synthesis in LPL (212). On the other hand, it has been demonstrated that polyamines can also inhibit lymphocyte proliferation (213215). The intracellular mechanisms by which ODC and polyamines modulate lymphocyte proliferation are still unknown. One possible mechanism was reported by Thomas et al. (216), who revealed that putrescine blocks the transmembrane $\mathrm{Ca}^{2+}-$ influx in $\mathrm{CD}^{+}$cells. This $\mathrm{Ca}^{2+}$-influx precedes cellular activation, IL-2 production and cell proliferation (217). In line with this, polyamines have been shown to inhibit IL-2 production by human peripheral blood mononuclear cells (211), lymphocytes (208) and murine lymphocytes (210) which suggests that polyamines act as a negative feedback, i.e. an anti-inflammatory mechanism, on cytokine production. Next to the inhibition of lymphocyte proliferation and IL-2 production, several other antiinflammatory properties of polyamines have been reported which include inhibition of mixed lymphocyte reaction (213-215), of histamine release by mast cells (218), of neutrophil activation $(219,220)$, and of nitric oxide (151-153) and $\mathrm{TNF}^{-}-\alpha(221,222)$ release by a murine macrophage cell line after LPS stimulation.

Polyamine oxidase oxidizes polyamines (see polyamine biosynthesis) and is present in bovine calf serum (BCS), a component in the culture medium (151-153, 213-215, 218-221). Serum PAO oxidizes, in contrast to intracellular PAO, spermine and spermidine into spermine aldehyde and spermidine aldehyde respectively (17) (Figure 2). These aldehydes will transform into spermidine and putrescine by spontaneous $\beta$-elimination of acrolein (17). Elimination of BCS from the cultures or replacement of BCS by human serum, which lacks $\mathrm{PAO}$ activity, resulted in abrogation of the above mentioned immunosuppressive effects of polyamines, 
indicating that $\mathrm{PAO}$ is involved in the immunosuppressive effects of polyamines (153, $207,218,219$ ).

Similar to these in vitro experiments, several other studies have indicated that exogenous polyamines are involved in the regulation of the physiological immune response in vivo $(26,34)$. Most of these data originate from cancer research. Tumors consist of rapidly proliferating cells and polyamine concentrations are increased in rapidly dividing cells. It has therefore been hypothesized that polyamine synthesis inhibitors might inhibit or even prevent tumor growth $(25,26,34,223,224)$. In support of this hypothesis, treatment of cultured tumor cells with DFMO, an irreversible ODC inhibitor, has been shown to inhibit cell proliferation (223). However, it has been demonstrated that the anti-tumoral effect of DFMO in vivo was limited, due to the abundant availability of tissue polyamines, as well as polyamines present in the diet and produced by the intestinal flora $(25,26,34,224)$. A combination of treatments to minimize polyamine content was necessary, in order to inhibit tumor growth in vivo. Such a combined treatment consisted of a polyamine deficient diet, antibiotics for decontamination of the gastrointestinal tract, and inhibitors of both polyamine biosynthesis and of the interconversion pathway, i.e. $O D C$ and PAO inhibitors (225-229). Together, these studies underscore once again the important role of polyamines in cellular proliferation of many cell types and tissues and point to the fact that polyamines can originate from different sources.

Chamaillard et al, showed that after tumor inoculation in a mouse, splenic polyamine levels were increased and paralleled by an inhibition of the immune response of the host. This inhibition in immuno reactivity was characterized by a decrease in splenic IL-2 production, in NK toxicity, in the number of leukocytes and in the number $\mathrm{CD} 4^{+} \mathrm{CD}^{+}$lymphocytes in the spleen $(26,230)$. Complete polyamine deprivation not only prevented tumor growth but also restored splenic IL-2 production, NK cytotoxic activity and the number of leukocytes and $\mathrm{CD} 4^{+} \mathrm{CD} 8^{*}$ cells to normal values as detected in non-tumor-bearing animals. The effect of polyamine deprivation on NK activity and IL-2 production was dependent on additional inhibition of PAO activity, implying a role for polyamine oxidation products in the inhibitory effects of polyamines on NK activity and IL-2 production. Furthermore, Thomas et al. (231) observed that the abnormal development of lymphocytes in the thymus of MLR-Ipr/pr mice was paralleled by increased thymic levels of putrescine and spermidine. The increase in $\mathrm{CD} 4 \mathrm{CD} 8$ lymphocytes and the clinical signs of autoimmune disease were abrogated after treatment with DFMO, indicating that enlanced polyamine levels were involved in the development of autoimmune disease. These studies demonstrate that polyamine deprivation not only prevents tumorinduced immune suppression but also reverses established immunological disorders $(26,230,231)$. Therefore, it can be suggested that polyamines are not only autocrine growth factors but also natural immunoregulatory mediators. 


\section{OUTLINE OF THE THESIS}

From the previous introduction it can be concluded that polyamines play a central role in intestinal mucosal development and function as well as in the immune system. Polyamine concentrations are enhanced during intestinal development and have shown to be important for morphological and biochemical intestinal maturation. Another essential feature of intestinal maturation is the development of the mucosal immune system after birth. Since immaturity of the neonatal mucosal immune system might be associated with a higher incidence of food intolerance, and given the fact that $90 \%$ of infants with food allergy become tolerant by the age of 3 years, we hypothesized that induction of precocious maturation of the mucosal immune system by polyamines might prevent the development of food intolerance. The first objective of this thesis, therefore, was to determine the role of polyamines in the ontogeny of the mucosal immune system.

Accordingly, in chapter 2, we describe a murine model to investigate the nomal development of membrane antigen expression of intraepithelial and lamina propria lymphocytes in the neonatal period.

In chapter 3 , we investigate the effect of oral spermine administration on the membrane antigen expression of intraepithelial and lamina propria lymphocytes in neonatal mice, using the model described in chapter 2 .

Both polyamine and NO production are upregulated during inflammation and have been shown to be controlled by many factors including pro- and anti-inflammatory mediators such as TNF- $\alpha$, IFN- $\gamma$, IL-1, IL-10. Enhanced production of NO during inflammation has been suggested to be involved in the induction of intestinal damage. The second objective of this thesis was to gain more insight in the development of intestinal damage during inflammatory disorders. We therefore investigated the role of NO and inflammatory mediators in human coeliac disease and in a murine endotoxic shock model.

In chapter 4 , the development of monoclonal antibodies against nitrotyrosine is described. These antibodies can be used for immunohistochemical staining as marker for NO-mediated damage and are also used in a newly developed sandwich ELISA to measure nitrated proteins present in serum samples.

The role of NO-mediated tissue damage in a clinical setting of intestinal inflammation is investigated in chapter 5 . In this study small bowel biopsy tissues of coeliac disease patients were immunohistochemically stained for iNOS and nitrotyrosine.

The role of endogenous TNF- $\alpha$, IFN- $\gamma$ and $1 L-10$ in LPS-induced NO release is investigated in chapter 6 using a mouse endotoxemia model.

In chapter 7, this model is used for an immunohistological study to investigate the contribution of the intestine to $\mathrm{NO}$ release during sepsis and to determine the role of endogenous TNF- $\alpha$, IFN- $\gamma$ and IL-10 in LPS-induced INOS expression. 
Since polyamines are important for intestinal repair and might have anti-inflammatory properties, we evaluated the actions of exogenous polyamines on L.PS-induced release of pro- and anti-inflammatory mediators in vitro as well as in vivo. Moreover, we sought to determine the effects of exogenous polyamines on LPS-induced intestinal damage.

In chapter 8 , we investigate the effect of spermine, spermidine, putrescine and cadaverine on LPS- or PHA-induced TNF- $\alpha, I L-6, I L-8$ and IL-10 release by human PBMCs and monocytes in vitro.

In chapter 9 , the effects of spermine administration on LPS-induced intestinal damage and the systemic release of the pro-inflammatory mediators TNF- $\alpha$, IFN- $\gamma$, $\mathrm{NO}$ and the anti-inflammatory cytokine IL-10 are investigated in vivo.

\section{REFERENCES}

1. Morgan DML. Polyamines. Essays in Blochemistry 23: 82-115, 1987.

2. Pegg AE. Recent advances in the biochemistry of polyamines in eukaryotes. Biochem $J 234$ : 249-262, 1986.

3. Tabor CW, Tabor H. Polyamines. Anm Rev Biochem 53: 749-790, 1984.

4. Pegg AE, McCann PP. Polyamine metabolism and function. Am J Physiol 243: C212-C221, 1982.

5. Bachrach U. Metabolism and function of spermine and related polyamines. Annu Rev Microbiol: 109-134, 1970.

6. Tabor H, Tabor CW. Spermidine, spermine, and related amines. Pharmacol Rev 16: 245-300, 1964.

7. Tabor H, Tabor CW. Biosynthesis and metabolism of 1,4-diaminobutane, spermidine and spermine, and related amines. Advan Enzymol Relat Areas Mol Biol 36:203-268, 1972

8. Lewenhoeck A. Observationes D. Anthonii Lewenhoeck de Natis è semine genitali Animal.culis. In Translated in Alle de brieven van Antoni van Leetwenhoek. Phil Trans $\mathbb{R}$ Sac Lond 1678 ; 12:1040-1043. JJ Swart NV Swets \& Zeitlinger (Eds.). Amsterdam, 1941.

9. Herbst EJ, Snell EE. Putrescine and related compounds as growth factors for Hemophilus parianfluenzae 7901. J Biol Chem 181:47-54, 1949

10. Cohen SS. What do polyamines do ? Nature 274:209-210, 1978 .

11. Willams-Asham GH, Canellakis ZN. Polyamines in mammalian biology and medicine. In Perspectives in biology and medicine, Springer-Verlag, pp. 421-453, 1979.

12. Bardocz S. The role of dietary polyamines. Eur J Clin Nutr $47: 683-690,1993$.

13. Heby O, Persson L. Molecular genetics of polyamine synthesis in eukaryotic cells. Trends Biochem Sci 15: 153-158, 1990.

14. Liappis N. Geschlechtsspezifische unterschiede der freien aminosauren im serum von erdwachsenen. Z Klin Chem Klin Biochem 10: 132-135, 1972.

15. Davis RH, Morris DR, Coffino P. Sequestered end products and enzyme regulation: the case of ornithine decarboxylase. Microbiol Rev 56:280-290, 1992. 16. Pegg AE, Shuttleworth K, Hibasami H. Specificity of mammalian spermidine synthase and
spermine synthase. Biochem $J 197: 315-320,1981$.

17. Seiler N, Bolkenhuis FN, Rennert OM. Interconversion, catabolism and elimination of the polyamines. Med Biol 59: 334-346, 1981. 
18. Maudsley DV, Leif $J$, Kobayashi $Y$. Ornithine decarboxylase in rat small intestine: Stumulation with food or insulin. Am J Physiol 231: 1557-1561, 1976.

19. Rudkin BB, Mamont PS, Seiler N. Decreased protein-synthetic activity is an early consequence of spermidine depletion in rat hepatoma tissue-culture cells. Biochem $J 217: 731-741,1984$.

20. Metcalf $B W$, Bey $\mathbb{P}$, Danzin $C$, Jung $M J$, Casara $P$, Vevert $J P$. Catabolic irreversible inhibition of mammalian omithine decarboxylase (E.C.4.1.17) by substrate and product analogues. If $A m$ Chem Soc 100:2551-2553, 1978 .

21. Tabata $\mathrm{K}$, Johnson LR. Ornithine decarboxylase and mucosal growth in response to feeding. Am JPhysial 251: G270-G274, 1986.

22. Seiler N, Dezeure F. Polyamine transport in mammalian cells. Imt J Biochem 22: 211-218, 1990.

23. Alhonen-Hongisto L, Seppanen $\mathrm{P}$, Janne J. Intracellular putrescine and spermidine deprivation induces increased uptake of the natural polyamines and methylglyoxal bis(guanylhydrazone. Biochen J 192: 941-945, 1980.

24. Byers TL, Pegg AE. Properties and physiological function of the polyamine transport system. Am J Physiol 257: C545-C553, 1989.

25. Hessels J, Kingma AW, Ferwerda H, Keij J, Van Den Berg GAVD, Muskiet FAJ. Microbial flora in the gastrointestinal tract abolishes cytostatic effects of $\alpha$-difluoromethylomithine in vivo. Int J Cancer 43: 1155-1164, 1989.

26. Chamaillard $\mathrm{L}$, Catros-Quemener V, Delcros JG, Bansard JY, Havouis R, Desury D, Commeurec A. Genetet N, Moulinoux JP. Polyamine deprivation prevents the development of tumourinduced immune suppression. Br J Cancer 76: 365-370, 1997.

27. Osborne DL, Seidel ER. Gastrointestinal luminal polyamines: Cellular accumulation and enterohepatic circulation. Am J Physiol 258: G576-G584, 1990.

28. Scemama JL, Grabrié V, Seidel ER. Characterization of univectoral polyamine transport in duodenal crypt cell line. Am J Physiol 265: G851-G856, 1993.

29. Barlier AM, Benamouzig R, Tomé D. Putrescine transport in differentiated Caco-2 cells. Gastroenterol Clin Biol 20: 178-184, 1996.

30. Bardócz S, Duguid TJ, Brown DS, Grant G, Pusztai A, White A, Ralph A. The importance of dietary polyamines in cell regeneration and growth. Br J Nutr 73: 819-828, 1995.

31. Hölta E. Oxidation of spermidine and spermine in rat liver: purification and properties of polyamine oxidase. Biochemistry 16:91-100, 1977.

32. Seller N, Bolkenius FN, Knödgen B, Mammont P. Polyamine oxidase in rat tissues. Biochint Biophys Acta 615: 480 488, 1980.

33. Brachet $\mathrm{P}$, Debbabi $\mathrm{H}$, Tomé D. Transport and steady state accumulation of putrescine in brusl.border membrane vesicles of rabbit small intestine, Am J Physiol 269: G754-G762, 1995 .

34. Sarhan S, Knödgen B, Seiler N. The gastrointestinal tract as polyamine source for tumor growth. Anticancer Res 9:215-223, 1989.

35. Henning SJ, Kretchmer N. Development of intestinal function in manmals. Enzyme 15:3-23, 1973.

36. Harada E, Hashimoto Y, Syoto B. Orally administered spermine induces precocious intestinal maturation of macromolecular transport and disaccharidase development in suckling rats. Comp Biochem Physiol 109A: 667-673, 1994.

37. Veress $B$, Baintner $K$. Absorption of colostrum in the rat and the cat: A comparative electron microscopic study. Acta Morphol Acad Sci Hung 19:335-347, 1971.

38. Arthur $\mathrm{AB}$. Development of disaccharidase activity in the small intestine of suckling mouse. $N Z$ Med J67: 614-616, 1968.

39. Klein RM, McKenzie JC. The role of cell renewal in the ontogeny of the intestine. I. Cell proliferation patterns in the adult, fetal and neonatal intestine. $J$ Pediatr Gastroenterol Nutr 2 : $10-43,1983$. 
40. Diamond JM. Hard-wired local triggering of intestinal enzyme expression. Narure 324: 408, 1986.

41. Luk GD, Marton LJ, Baylin SB. Ornithine decarboxylase is important in intestinal mucosal maturation and recovery from injury in rats. Science 210: 195-198, 1980.

42. Ferguson A, Parrotf DM. Growth and development of "antigen-free" grafts of foetal mouse intestine. J Pathol 106: 95-101, 1972.

43. Bandeira $A$, Mota-Santos $T$, Itohara $S$, Degermann $S_{1}$ Heusser $C$, Tonegawa $S$, Coutinho $A$. Localization of $\gamma / \hat{0} \mathrm{~T}$ cells to the intestinal epithelium is independent of nomal microbial colonization. $J$ Exp Med 172: 239-244, 1990.

44. Mosley RL, Klein JR. Peripheral engraftnent of fetal intestine into athymic mice sponsors $\mathrm{T}$ cell development:. Direct evidence for thymopoietic function of murine small intestine. $J$ Exp Med 176: $1365-1373,1992$.

45. Yeh $\mathrm{KY}$, Holt PR Ontogenic timing mechanism initiates the expression of rat intestinal sucrase activity. Gastroenterology 90: 520-526, 1986.

46. Tsuboi K, Kwong $\mathbb{L}$ K, Ford WD, Colby T, Sunshine P. Delayed ontogenic development in the bypassed ileum of the infant rat. Gastroenterology 80:1550-1556, 1981.

47. Henning SJ. Postratal development : coordination of feeding, digestion, and metabolism. Am $J$ Physial 241: G199-G214, 1981.

48. Lebenthal $\mathbb{E}$, Sunshine P, Kretchmer $\mathbb{N}$ Effect of prolonged nursing on the activity of intestinal lactase in rats. Gastroenterology 64: 1136-1141, 1973.

49. Alarcon P. Lebenthal E, Lee PC. Effect of difluoromethylomithine (DFMO) on small intestine of adult and weanling rats. Dig Dis Sci 32: 883-888, 1987.

50. Malo C, Qureshi LA. Letarte J. Postnatal maturation of enterocytes in sparse-fur mutant mice. Ams IPhysiol 250: G177-G184, 1986.

51. Menard D, Malo C, Calvert R. Insulin accelerates the development of intestinal brush border hydrolytic activities of suckling mice. Dev Biol 85: 150-155, 1981.

52. Malo C, Ménard D. Influence of epidermal growth factor on the development of suckling mouse intestinal mucosa. Gastroenterology $83: 28-35,1982$.

53. Feldman EJ, Aures D, Grossman Ml. Epidermal growth factor stimulates ornithine decarboxylase activity in the digestive tract of mouse. Proc Soc Exp Biol Med 159: 400-402, 1978.

54. Fitzpatrick LR, Wang P, Johnson LR. Effect of epidermal growth factor on polyaminesynthesizing enzymes in rat enterocytes. Am J Physiol 252: G209-G214, 1987.

55. Dufour $C$, Dandrifosse $G$, Forget $P$, Vermesse $F$, Romain $N$, Lepoint $\mathbb{P}$. Spermine and spermidine induce intestinal maturation in the rat. Gastroenterology 95: 112-1.16, 1988.

56. Georges $\mathbb{P}$, Dandrifosse $\mathrm{G}$, Vemesse $F$, Forget P, Deloyer $P$, Romain $N$. Reversibility of spermine-induced intestinal maturation in the rat. Dig Dis Sci 35: 1528*1536, 1990.

57. Buts JP, De Keyser N, Kolanowski J, Sokal E, Van Hoof F. Maturation of villus and crypt cell functions in rat small intestine: Role of dietary polyamines. Dig Dis Sci 38: 1091-1098, 1993.

58. Wild GE, Daly AS, Sauriol N, Bennett $\mathrm{G}$. Effect of exogenously administered polyamine on the structural maturation and enzyme ontogeny of the postnatal rat intestine. Biol Neonate 63: 246 257,1993

59. Kaouass M, Sulon J, Deloyer P, Dandrifosse G. Spermine-induced precocious intestinal maturation in suckling rats; possible involvement of glucocorticoids. J Endocrinol 141:279-283, 1994.

60. Kaouass M, Deloyer P, Wery I, Romain N, Dandrifosse G. Methods of spermine administration for inducing precocious digestive tract maturation. In Polyamines in the Gastrointestinal tract. Dowling RH, Fölsch UR, and Löser C (Eds.) vol 62 pp. 516, 1991.

61. Kaouass $M$, Deloyer $\mathbb{P}$, Dandrifosse $\mathbf{G}$. Intestinal development in suckling rats: direct or indirect spermine action? Digestion 55: 160-167, 1994. 
62. Doell RG, Kretchmer N. Intestinal invertase: Precocious development of activity after injection of hydrocortisone. Science 143: 42-44, 1963.

63. Moog F, Yeh K. Pinocytose persists in the ileum of hypophysectomized rats unless closure is induced by thyroxine or cortisone. Dev Biol 69: 159-169, 1979.

64. Bienenstock J, Befus AD. Mucosal Immunology. Immunol 41:249-270, 1980

65. Trejdosiewicz LK. Intestinal intraepithelial lymphocytes and lymphoepithelial interaction in the human gastrointestinal mucosa. Immunol Lett 32:13-19, 1992

66. Rocha B, Vassalli P, Guy-Grand D. The extrathymic T-cell development pathway. Inmunol Today 13:449-454, 1992.

67. Poussier $P$, Julius $M$. Thymus independent $T$ cell development and selection in the intestinal epithelium. Anmu Rev Inumunol 12:521-553, 1994.

68. Strobel S. Immunologically mediated damage to the intestinal mucosa. Acta Paediar Scand Suppl 365: 46-57, 1990.

69. Stokes CR, Bailey M, Wilson AD. Imumunology of the porcine gastrointestinal tract. Vet Immunoi Immunop 43: 143-150, 1994.

70. GuyuGrand D, Cerf-Bensussan N, Malissen B, Malassis-Seris M, Briotter C, Vassalli P. Two gut intraepithelial $\mathrm{CD} 8^{*}$ lymphocyte populations with different $T$ cell receptors: a role for the gut epithelium in T cell differentiation. $J \operatorname{Exp} M e d 1.73: 471-481,1991$.

71. Mayer L, Panja A, Li Y, Siden S, Pizzimenti A, Gerardi F, Chandswang N. Unique features of antigen presentation in the intestine. An NY Acad Sci 664: 39-46, 1992.

72. Hoang $\mathrm{P}$, Crotty $\mathrm{B}$, Dalton HR, Jewell DP. Epithelial cells bearing class II molecules stinulate allogeneic human colonic intraepithelial lymphocytes. Gut 33: 1089-1093, 1992.

73. Bandeira A, Itohara S, Bonneville M, Burlen-Defranoux O, Mota-Santos T, Coutinho A, Tonegawa S. Extrathymic origin of intestinal intraepithelial lymphocytes bearing T-cell antigen receptor yó. Proc Natl Acad Sci USA 88: 43-47, 1991.

74. Rocha $B$, Vassalli $P$, Guy-Grand $D$. The VB repertoire of mouse gut homodimeric $\alpha$ CD8 ${ }^{\circ}$ intraepithelial $T$ cell receptor $\alpha / \beta^{*}$ lymphocytes reveals a major extrathymic pathway of $T$ cell differentiation. J Exp Med 173: 483-486, 1991.

75. Rocha B, Vassalli P, Guy-Grand D. Thymic and extrathynic origins of gut intraepithelial lymphocyte populations in mice. J Exp Med 180:681-686, 1994.

76. Lyscom N, Brueton MJ. The development of intraepithelial and Peyer's patch lymphacyte subtypes in the small intestine of newborn rats. Clin Exp Immunol 54: 158 162. 1983.

77. Rothkötter HJ. Kirchhoff T, Pabst R. Lymphoid and non-lymphoid cells in the eputhelium and lamina propria of intestinal mucosa of pigs. Gu $35: 1582-1589,1994$.

78. De Geus B, Rozing J Co-expression of TCR- 13 and TCR- 8 chains on intestinal lamina propria lymphocytes during neonatal development in euthymic and in athymic mice. In: thesis, Differentiation and characterization of murine intestinal epithelial lymphocytes. (" 3 -Gravenhage. Pasmans BV) pp. 90-109, 19992.

79. De Geus B, Shultz LD, van den Enden M, Coolen C, Rozing J. Analysis of intestinal intraepithelial lymphocytes in athymic (nude) and scid mice. In: Advances in Mucosal Immunology, Mc Donald TT et al. (Eds.) Kluwer academic publishers, Dordrech/Boston/London, pp. 71, 1990.

80. Machado CSM, Rodrigues MAM, Maffei HVL. Assessment of gut intraepithelial lymphocytes during late gestation and the neonatal period. Biol Neonate 66: 324*329, 1994 .

81. Johnson LR, Tseng CC, Wang P, Tipnis UR, Harldox MK. Mucosal om thine decarboxylase in the small intestine: Localization and stimulation. Am J Physio/ 256: G624-G630, 1989.

82. Yarrington IT, Sprinkle DJ, Loudy DE, Diekema KA, McCann PP, Gibson JP. Intestinal changes caused by DL-alpha-difluoromethylornithine (DFMO), an inhibitor of ornithine decarboxylase. Exp Mol Pathol 39: 300-316, 1983. 
83. Wang JY, McCormack SA, Viar MJ, Johnson LR. Stimulation of proximal small intestinal mucosal growth by luminal polyamines. Am J Physiol 261: G504-G511, 1991.

84. Madsen KL, Brockway PD, Johnson LR, Hardin JA, Gall DG. Role of ormithine decarboxylase in enterocyte mitochondrial function and integrity. Am J Physiol 270: G789-G797, 1996.

85. Alarcon $\mathrm{P}_{\text {, }}$ Lin $C H_{3}$ Lebenthal $E$, Lee $\mathrm{PC}$. Interaction of malnutrition and difluoromethylomithine-induced intestinal mucosal damage: degree of severity and subsequent recovery. Digestion $41 ; 68-77,1988$.

86. Bamba T, Vaja S, Murphy GM, Dowling RH. Effect of fasting and feeding on polyamines and related enzymes along the villus:crypt axis. Digestion 46 Suppl 2: 424-429, 1990.

87. Hosomi M, Stace NH, Lirussi $\mathbb{E}$, Smith SM, Murphy GM, Dowling RH. Role of polyamines in intestinal adaptation in the rat. Eur J Clin Invest 17: 373-385, 1987.

88. Cynober L. Can arginine and omithine support gut functions? Gut Suppl 1: S42-S45, 1994.

89. Erdman SH, Park JHY, Thompson IS, Grandjean CJ, Hart MH, Vanderhoof JA. Suppression of diamine oxidase activity enhances postresection ileal proliferation in the rat. Gastroenterology 96: 1533-1538, 1989 .

90. Rokkas T, Vaja S, Murphy GM, Dowling RH. Aminoguanidine blocks intestinal diamine oxidase (DAO) activity and enhances the intestinal adaptive response to resection in the rat. Digestion 46 Suppl 2: 447-457, 1990.

91. Dowling RH. Polyamines in intestinal adaptation and disease. Digestion 46 suppl 2: 331-344, 1990.

92. Luk GD, Bayless TM, Baylin SB. Diamine oxidase (histaminase). A circulating marker for rat intestinal mucosal maturation and integrity. $J$ Clin Invest 66: 66-70, 1980.

93. Forget P. Grandfils $C$, Van Cutsem JL, Dandrifosse G. Diamine oxidase and disaccharidase activities in small intestinal biopsies of children. Pediatr Res 18: 647-649, 1984.

94. DAgostino L, D'Argenio G, Ciacci C, Daniele B, Macchia V, Mazzacca G. Diamine oxidase in rat small bowel: distribution in different segments and cellular location. Enzyme 31:217-220, 1984.

95. Robinson- White A, Baylin SB, Olivecrona T, Beaven MA. Binding of diamine oxidase activity to rat and guinea pig microvascular endothelial cells. Comparisons with lipoprotein lipase binding. J Clin Invest 76: 93-100, 1985.

96. Pusztai A, Grant G, Brown DS, Ewen SWB, Bardocz S. Phaseolus vulgaris lectin induces growth and increases the polyamine content of rat small intestine in vivo. Med Sci Res 16: 12831284, 1988 .

97. Bardocz $\mathrm{S}$, Grant G, Brown DS, Wallace HM, Ewen sWB, Pusztai A. Effect of $\alpha-$ difluoromethylornithine on Phaseolus vulgaris lectin-induced growth of the rat small intestine. Med Sci Res 17: 143-145, 1989.

98. Bardocz S, Grant G, Brown DS, Ewen SWB, Nevison I, Pusztai A. Polyamine metabolism and uptake during Phaseolus valgaris lectin, PHA-induced growth of the rat small intestine. Digestion 46 Suppl: 360-366, 1990.

99. Pusztai A, Grant G, Williams LM, Brown DS, Bardocz S. Phaseolus vulgaris lectin induces growth and the uptake of polyamines by the rat small intestine in vivo. Med Sci Res 17: 215-217, 1989

100. Sessa A, Tumici P, Ewen SW, Grant G, Pusztai A, Bardocz S, Perin A. Diamine and polyamine oxidase activities in phytohaemagglutinin-induced growth of rat small intestine. Biochim Biophys Acta 1244: 198-202, 1995.

101. Bardocz S, Brown DS, Grant G, Pusztai A. Luminal and basolateral polyamine uptake by rat small intestine stimulated to grow by phaseolus vulgaris lectin phytohaemagglutinin in vivo. Biochim Biophys Acta 1034: 46-52, 1990.

102. Wang JY, Johnson LR. Induction of gastric and duodenal mucosal ornithine decarboxylase during stress. Am J Physial 257: G259-Gi265, 1989. 
103. Wang JY, Johnson LR, Tsai YH, Castro GA. Mucosal ornithine decarboxylase, polyamines and hyperplasia in infected intestine. Am J Physiol 260: G45-G51, 1991.

104. Fujimoto K, Granger DN, Price VH, Tso P. Omithine decarboxylase is involved in repair of small intestine after ischemia-reperfusion in rats. Am J Physiol 261: G523-G529, 1991.

105. Kummerlen C, Seiler N, Galluser M, Gossé F, Knodgen B, Hasselmann M, Raul F. Polyamines and the recovery of intestinal morphology and function after ischemic damage in rats. Digesion 55: $168-174,1994$.

106. Chung DH, Evers BM, Townsend CM, Huang KF, Shimoda I, Herndom DN, Thompson JC. Burn-induced transcriptional regulation of small intestinal ornithine decarboxylase. Am $J$ Surg 163: 157-162, 1992.

107. Noguchi $\mathrm{Y}$, Meyer TA, Tiao G, Ogle CK, Fischer JE, Hasselgren PO. Influence of sepsis and endotoxemia on polyamine metabolism in mucosa of small intestine in rats. Melabolism 45: 28 $33,1996$.

108. Luk GD. Baylin SB. Inhibition of intestinal epithelial DNA synthesis and adaptive hyperplasia after jejunectomy in rat by suppression of polyamine biosynthesis. $J$ Clin Imvest 74: 698-704, 1984.

109. Michalsky MP, Deitch EA, Ding J, Lu Q, Huang Q. Interleukin-6 and tumor necrosis factor production in an enterocyte cell model (Caco-2) during exposure to Escherichia Coli. Shock 7 : $139-146,1997$.

110. Ogle CK, Mao JX, Wu JZ, Ogle JD, Alexander JW. The production of numor necrosis factor, interleukin-1, interleukin-6 and prostgladin E2 by isolated enterocytes and gut macrophages. Effect of lipopolysaccharide and thermal injury. J Bum Care Rehab 15: 470-477, 1994.

11.1. von Allmen D, Hasselgren PO, Higashiguchi T, Frederick J, Zamir O, Fischer JE. Increased intestinal protein synthesis during sepsis and following the administration of tumour necrosis factor $\alpha$ or interleukin $1 \alpha$. Biochem $J 286: 585-589,1992$.

112. Noguchi $Y$, Meyer $T$, Tiao G, Fischer JE, Hasselgren PO. Sepsis increases putrescine concentration and protein synthesis in mucosa of small intestine in rats. Shock 5:333-340, 1996.

113. Chung DH, Evers BM, Townsend CM, Herndon DN, Ko TC, Uchida T, Thompson JC. Cytokine regulation of gut ornithine decarboxylase gene expression and enzyme activity. Surgery 112 : $364-369,1992$.

114. Wang JY, Viar MJ, Johnson LR. Regulation of transglutaminase activity by polyamines in the gastrointestinal mucosa of rats. PSEBM 205: 20-28, 1994.

115. Wang $\sqrt{ }$, Johnson $L R$. Role of transglutaminase and protein cross-linking in the repair of mucosal stress erosions. Am J Physiol 262: G818-G825, 1992.

116. Folk JE. Transglutaminases. Anmu Rev Biochem 49; 517-531, 1980.

117. McCormack SA, Wang IY, Viar MJ, Tague L, Davies PJ, Johnson LR. Polyamines influence transglutaminase activity and cell migration in two cell lines. Anw I physiol 267: C706-C714, 1994.

118. Santos MF, Viar MJ, McCormack SA, Johnson LR. Polyamines are important for attachment of IEC-6 cells to extracellular matrix. Am $J$ Physiol 36: G175-G183, 1997.

119. Wathan C. Nitric oxide as a secretory product of mammalian cells. FASEB J6: $3051-3064,1992$.

120. Nussler AK, Billiar TR. Inflammation, immunoregulation, and inducible nitric oxide synthase. $J$ Leukocyte Biol 54: 171-178, 1993.

121. Kubes P, Suzuki M, Granger DN. Nitric oxide: an endogenous modulator of leukocyte adhesion. Proc Nat Acad Sci USA 88: 4651-4655, 1991.

122. MacNaugthon WK, Cirino $G$, Wallace IL. Endothelium-derived relaxing factor (nitric oxide) has protective actions in the stomach. Life Sci 45: 1869-1876, 1989.

123. Pique JM, Esplugues JV, Whittle BJR. Endogenous nitric oxide as a mediator of gastric mucosal vasodilatation during acid secretion. Gastroenterology 102: 168-174, 1992. 
124. Vanderwinden MM, DeLaet MH, Schiffmann SN, Mailleux P, Lowenstein CI, Snyder SH, Vanderhaeghen $\mathbb{J}$. Nitric oxide synthase distribution in the enteric nervous system of Hirschsprung's discase. Gastroenterology 105: 969-973, 1993.

125. Huang PL, Dawson IM, Bredt DS, Snyder SH, Fishman MC. Target distuption of the neural nitric oxide synthase gene. Cell $75 ; 1273-1286,1993$.

126. Wilmore DW, Smith RJ, ODwyer ST, Jacobs DO, Ziegler TR, Wang XD. The gut: A central organ after surgical stress. Swrgery 104: $917-923,1988$.

127. Chen $K$, Inoue $M$, Okada $A$. Expression of inducible nitric oxide synthase mRNA in rat digestive tissues after endotoxin and its role in intestinal mucosal injury. Biochem Biophys Res Commun 224: 703-708, 1996.

128. Deitch EA, Berg R, Specian R. Endotoxin promotes the translocation of bacteria from the gut. Arch Surg 122: 185-190, 1987.

129. Hutcheson IR, Whittle BJR, Boughton-Smith NK. Role of nitric oxide in maintaining vascular integrity in endotoxin-induced acute intestinal damage in the rat. $B r J$ Phormacol 101: 815-820, 1990.

130. Miller MJS, Sadowska-Krowicka $H_{3}$ Chotinareumol S, Kakkis JL, Clark DA. Amelionation of chronic ileitis by nitric oxide synthase inhibition. I Pharmacol Exp Ther 264: 11-16, 1993.

131. Ribbons KA, Zhang XI, Thompson JH, Greenberg SS, Moore WM, Kommeier CM, Currie MG, Lerche N, Blanchard I, Clark DA, Miller MJS. Potential role of nitric oxide in a model of chronic colitis in rhesus macaques. Gastroenterology 108: 705-711, 1995.

132. Grisham MB. Animal models of inflammatory bowel disease. Curr Opin Gastroenterol 9: 524$533,1993$.

133. Miller MS, Thompson JH, Zhang XJ, Sadowska-Krowicka H, Kakkis JL, Munshi UK, Sandoval M, Rassi JL, Eloby-Childress S, Becknan JS, Ye YZ, Rodi CP, Manning PT, Currie $\mathrm{MG}$, Clark DA. Role of inducible nitric oxide synthase expression and peroxynitrite formation in guinea pig ileitis. Gastroenterology 109: 1475-1483, 1995.

134. Middleton SJ, Shorthouse $M$, Hunter JD. Increased nitric oxide synthesis in ulcerative colitis. Lancet 341: 456-466, 1993.

135. Roediger WEW, Lawson MJ, Nance SH, Radeliffe BC. Detectable colonic nitrite levels in inflammatory bowel disease-mucosal or bacterial malfunction ? Digestion 35: 199-204, 1986 .

136. Kilbourn RG, Gross SS, Jubran A, Adams J, Griffith OW, Levi R, Lodato RF. NG-methyl-Larginine inhibits tumor necrosis factor-induced hypotension: Implications for the irvolvement of nitric oxide. Proc Nafl Acad Sci USA 87: 3629-3632, 1990.

137. Cunha IFQ. Assreuy J, Moss DW, Rees D, Leal LMC, Moncada S, Carrier M, ODonnell CA, Liew FY. Differential induction of nitric oxide synthase in various organs of the mouse during endotoxaemia: role of TNF- $\alpha$ and IL-1-B. Immunology $81: 211-215,1994$.

138. Martin $\mathrm{E}$, Nathan $\mathrm{C}$, Xie $\mathrm{Q}$. Role of interferon regulatory factor 1 in induction of nitric oxide synthase. J Exp Med 180:977-984, 1.994.

139. Zidek Z, Lotzová E, Franková D, Savary CA. Indirect stimulatory effects of murine interleukin12 on in vitro production of nitric oxide by mouse peritoneal cells. I hrerferon Cytokine Res 16 : 389-393, 1996.

140. Asai K, Kato H, Kimura S, Mukai S, Kawahito Y, Sano H, Kondo M, Akaogi K, Hirose K. Induction of gen expression for nitric oxide by immunomodulating drugs in the RAW264.7 murine macroplage cell line. Cancer Immunol Immun 42: 275-279, 1996.

141. Chen B, Stout R, Campbell WF. Nitnic oxide production: a mechanism of Chlamydia rachomatis inhibition in interferon- $\gamma$-treated RAW264.7 cells. FEMS Immunol Med Microbiol 14: $109-120,1996$.

142. Yuhas $\mathrm{Y}$, Kaminsky $\mathbb{E}$, Mor M, Ashkenazi $S$. Induction of nitric oxide production in mouse macrophages by Shiga toxin. J Med Microbiol 45: 97-102, 1996. 
143. Kubes P, Reinhard PH, Payne D, Woodman RC. Excess nitric oxide does not cause cellular, wascular or mucosal dysfunction in the cat small intestine. Am JPhysiol 269: G34-G41, 1995.

144. Kubes?. Wallace JL. Nitric oxide as a mediator of gastrointestinal mucosal injury ? Say it aint so. Med Hinfanm 4: 397-405, 1995.

145. Beckman IS, Beckman TW, Chen J, Marshall PA, Freeman BA. Apparent hy droxyl radical production by peroxynitrite: implications for endothelial injury from nitric oxide and superoxide. Proc Nat ACad Sci USA 87: 1620-1624, 1990.

146. Beckman IS, Crow IP. Pathological implications on nitric oxide, superoxide and peroxynitrite formation. Biochem Soc Trans 211 : 330-334, 1993.

147. Beckmann JS, Ye YZ, Anderson PG, Chen J, Accavitti MA, Tarpey MM, White CR. Extensive nitration of protein tyrosines in human atherosclerosis detected by immunohistochemistry. Biol Chem 375:81-88, 1994.

148. Ischiropoulos H, Zhu L, Chen J, Tsia M, Martin JC. Smith CD, Beckman JS. Peroxynitritemediated tyrosine nitration catalyzed by superoxide dismutase. Arch Biochem Biophys 298: 431$437,1992$.

149. Radi R, Beckman JS, Bush KM, Freeman BA. Peroxynitrite oxidation of sulfhydryls. The cytotoxic potential of superoxide and nitric oxide. I Biol Chem 266: 4244-4250, 1991.

150. Rachmilewitz D, Stamler JS, Karmeli F, Mullins ME, Singel DJ, Loscalzo J, Xavier RJ, Podolsky DK. Peroxynitrite-induced rat colitis - A new model of colonic inflammation. Gastroenterology 105: 1681-1688, 1993.

151. Szabó C, Southan GJ, Wood E, Thiemermann C, Vane JR. Inhibition by spermine of the induction of nitric oxide synthase in $\$ 774.2$ macrophages: Requirement of a serum factor. $\mathrm{Br} J$ Pharmacol 112:355-356, 1.994 .

152. Southan GJ, Szabó $C$, Thiemermann $C$. Inhibition of the induction of nitric oxide synthase by spermine is modulated by aldehyde dehydrogenase. Biochem Biophys Res Comm 203: 16381644,1994 .

153. Szabó C, Southan GJ, Thiemermann C, Vane JR. The mechanism of the inhibitory effect of polyamines on the induction of nitric oxide synthase: Role of aldehyde metabolites. $B \mathrm{r} d$ Pharmacol 113: 757-766, 1994.

154. Das I, Khan NS. Differing effects of polyamines on nitric oxide synthase. Brochem Soc Trans 24 : $484 \mathrm{~S}, 1.996$.

155. Blachier F, Robert V, Selamnia M, Mayeur C, Duee PH. Sodium nitroprusside inhibits proliferation and putrescine synthesis in human colon carcinoma cells. FEBS Let 396: 315-318. 1996.

156. Marsh MN. Morphology and immunopathology of the jejunal lesion in gluten-sensitivity. Eur ,J Gastroenterol Hepatol 3: 108-114, 1992.

157. Marsh MN, Lof DE, Garner VG, Gordon DI. Time/dose response of coeliac mucosae to graded oral challenges with Frazer"s fraction III of gliadin. Eur J Gastroenterol Hepathol 4: 667-673, 1992.

158. Spencer J, MacDonald TT, Diss TC, Walker-Smith JA, Ciclitira PJ, Isaacson PG. Changes in intraepithelial lymphocyte subpopulations in coeliac disease and enteropathy associated $\mathrm{T}$ cell lymphoma (malignant histiocytosis of the intestine). Gut 30:339-346, 1989.

159. Brandzaeg P, Halstensen TS, Kett K, Krajci P, Kvale D, Rognum TO, Scott H, Sollid LM. Immunobiology and immunopathology of human gut mucosa: humoral immunity and intraepithelial lymphocytes, Gastroenterology 97: 1562-1584, 1989.

160. Volta U, Molinaro $N$, Fusconi $M$, Cassani $F_{3}$ Bianch FB. JgA antiendomysial antibody test: $A$ step forward in celiac disease screening. Dig Dis Sci 36: 752-756, 1991.

161. Lemer A, Kumar V, Iancu TC. Inmunological diagnosis of childhood coeliac disease: comparison between antigliadin, antireticulin and antiendomysial antibodies. Clin Exp Immurol $95: 78-82,1994$. 
162. Riecken EO, Stewart IS, Booth CC, Pearse AGE. A histochemical study on the rolle of lysosomal enzymes in idiopathic steatorthea before and during a gluter-free diet. Gut 7:317-332, 1966.

163. Peters TJ, Jones PE, Wells G. Analytical subcellular fractionation of jejunal biopsy specimens: enxyme activities, organelle pathology and response to gluten withdrawal in patients with coeliac disease. Clin Sci Mol Med 55: 285-292, 1978.

164. Bjarmason I, Peters TJ, Veall N. A persistent defect in intestinal permeability in coeliac disease demonstrated by a ${ }^{51}$ Cr-labelled EDTA absorption test. Lancel 1: 323-325, 1983.

165. Bjamason I, Peters TJ. In vitro determination of small intestinal permeability; demanstration of a persistent defect in patients with coeliac disease. Fut 25: 145-150, 1984.

166. Douglas AP. The binding of a glycopeptide component of wheat to intestinal mucosa of normal and coeliac human subjects. Clin Chim Acta 73: 357-361, 1976.

167. Kottgen E, Volk B, KJuge F, Gerok W. Gluten, a lectin with oligomannosyl specificity and the causative agent of gluten-sensitive enteropathy. Biochem Biophys Res Commun 109: 168-173, 1982.

168. Bruce SE, Bjarnason I, Peters TJ. Human jejunal transglutaminase: Demonstration of activity, enzyme kinetics and substrate specificity with special relation to gliadin and coeliac disease. Clin Sci 68: $573-579,1985$.

169. Dieterich W, Ehnis T, Bauer M, Donner P, Volta U, Riecken EO, Schuppan D. Identification of tissue transglutaminase as the autoantigen of celiac disease. Nature Med 3: 797-801, 1997.

170. Kontakou M, Przemioslo RT, Sturgess RP, Limb AG, Ciclitira PJ. Expression of tumor necrosis factor- $\alpha$, interleukin- 6 and interleukin- 2 mRNA in the jejunum of patients with coeliac disease. Scand J Gastroenterol 30: 456 463, 1995.

171. Chowers Y, Marsh MN, Degrandpre L, Nyberg A, Theofilopoulos AN, Kagnoff MF. Increased proinflammatory cytokine gene expression in the colonic mucosa of coeliac disease patients in the early period after gluten challenge. Clin Exp Immunol 107: 141-147, 1997.

172. Breese EJ, Kumar P, Farthing MJ, MacDonald TT. Interleukin-2 and interferon- $\gamma$ producing cells in the lamina propria in celiac disease. Dig Dis Sci 39:2243, 1994.

173. Nilsen EM, Lundin KEA, Krajci P, Scott H, Sollid LM, Brandtzaeg P. Gluten specific, HLA-DQ restricted $T$ cells from coeliac mucosa produce cytokines with Thl or Tho profile dominated by interferon $\gamma$. Gut 37: 766-776, 1995.

174. Przemioslo RT, Lundin KEA, Sollid LM, Nelufer J, Ciclitira PJ. Histological changes in small bowel mucosa induced by gliadin sensitive $T$ lymphocytes can be blocked by anti-interferon $\gamma$ antibody. Gur 36: 874-879, 1995.

175. Kubes P. Nitric oxide modulates epithelial permeability in the feline small intestine. A $m J$ Physial 262: G1138-G1142, 1992.

176. Unno N, Menconi MJ, Smith M, Fink MP. Nitric oxide mediates interferon- $\gamma$-induced hyperpermeability in cultured human intestinal epithelial monolayers. Crit Care Med 23: 1170$1176,1995$.

177. Bendix U, Lentz S, Rothschild M, Lehmann I, Osman AA, Mothes T. Effect of $\gamma$-interferon on binding of gliadin and other food peptides to the hurnan intestinal cell line HT-29. Clin Chim Acta 261: 69-80, 1997.

178. Mothes T, Bendix U, Pfannschmidt C, Lehmann I. Effect of gliadin and other food peptides on expression of MHC class II molecules by HT-29 cells. Gut 36: 548-552, 1995.

179. Falchuk $Z M$, Gebhard RN, Sessoms C, Strober W. An in vitro model of gluten sensitive enteropathy. J Clin Invest 53: 487-500, 1974.

180. Falchuk ZM, Gebhard RL, Strober W. The pathogenesis of gluten-sensitive enteropathy (coeliac sprue); organ culture studies. In Coeliac Disease. Proceedings of 2 nd International Symposium. Hekkens. WTHIM, Pena AS (Eds.), Stenfert Kroese, Leiden, the Netherlands pp. 107-117, 1974. 
181. Jos J, Lenoir G, De Ritis $G$, Rey J. In vitro pathogenetic studies of coeliac disease. Effect of protein digests on coeliac intestinal biopsy specimens maintained in culture for 48 hours. Scamd J Gastroenterol 10:121-128, 1975 .

182. Fluge G, Aksnes L. Morphological and morphometric assessment of human duodenal biopsies maintained in organ culture. Scand J Gastroenter ol 16: 555-567, 1981 .

183. Fluge G, Andersen KJ, Aksnes L, Thunold K. Brush border and lysosonal marker enzyme: profiles in duodenal mucosa from coeliac patients before and after organ culture. Scand $d$ Gastroenterol 17: 465-472, 1982.

184. Aurichio S, De Ritis G, De Vincenzi M, Occorsio P, Silano V. Effect of gliadin-derived peptides prepared from bread and durum wheats on small intestine cultures from rat fetus and coeliac children. Pediatr Res 16: 1004-1010, 1982.

185. Aurichio $S$, De Ritis G, De Vincenzi M, Mancini $\mathbb{E}$, Minetri $M$, Sapora $O$, Silano $V$. Agglutinating activity of gliadin-derived peptides from bread wheat: implications for coeliac disease pathogenesis. Biochem Biophys Res Commun 121:428-433, 1984.

186. De Ritis $G$, Occorsio $P$, Auricchilo $S$, Gramenzi $\mathbb{F}$, Morisi $G$, Silano V. Toxicity of wheat flour proteins and protein-derived peptides for in vitro developing intestine from rat fetus. Pedian Res 13: 1255-1261, 1979.

187. Auricchio $S$, De Ritis $G$, De Vincenzi M, Gentile V, Maiuri L, Mancini E, Porta R, Raia V. Amines protect in vitro the celiac small intestine from the damaging activity of gliadin peptides. Gastroenierology 99: 1668-1674, 1990.

188. Rokkas T, Vaja S, Murphy GM, Dowling RH. Post-heparin plasma diamine oxidase (DAO) in health and intestinal disease. Gastroenterology 98 : 1493-1501, 1990.

189. Forget P, Grandfils C, Van Cutsem $\Omega$, Dandrifosse G. Diamine oxidase in serum and small intestinal biopsy tissue in childhood celiac disease. J Pediatr Gastroenterol Nutr 5: 379-383, 1986.

190. Higashiguchi $\mathbb{T}$, Noguchi $Y$, O'Brien W, Wagner K, Fischer JE, Hasselgren PO. Effect of sepsis on mucosal protein synthesis in different parts of the gastrointestinal tract in rats. Clin Sci Colch 87: 207-211, 1994.

191. Yoshida S, Leskiw MJ, Schluter MD, Bush KT, Nagele RG, Lanza-Jacoby S, Stein TP. Effect of total parental mutrition, systemic sepsis, and glutamine on gut mucosa in rats. Am J Physiol 263: E368-E373, 1992.

192. Higashiguchi T, Noguchi Y, Meyer T, Fischer JE, Hasselgren PO. Protein synthesis in isolated enterocytes from septic or endotoxaemic rats: regulation by glutamine. Ciin Sci Colch 89: 311. 319,1995

193. Poyhonen MJ, Takala JA, Pitkanen O, Kari A, Alakuijala LA, Eloranta TO. Differential effects of sepsis and trauma on urinary excretion of polyamines. Nutrition $9: 406-410,1993$.

194. Endo Y. Simultaneous induction of histidine and ornithine decarboxylase and changes in their product amines following the injection of Escherichia Coli lipopolysaccharide into mice. Biochem Pharmacol 31: 1643-1647, 1982.

195. Meyer TA, Wang JJ, Tiao GM, Ogle CK, Fischer JE, Hasselgren PO. Sepsis and endotoxemia stimulate intestinal interleukin-6 production. Surgery 118: 336-342, 1995.

196. Higashiguchi $T$, Noguchi $\mathrm{Y}$, Noffsinger A. Fischer JE, Hasselgren PO. Sepsis increases production of total secreted proteins, vasoactive intestinal peptide, and peptide $Y Y$ in isolated rat. enterocytes. Am J Surg 168: 251-256, 1994.

197. Florquin S, Amraoui Z, Dubois C, Decuyper J, Goldman M. The protective role of endogenously synthesized nitric oxide in staphylococcal enterotoxin B-induced shock in mice. J Exp Med 180 : $1153-1158,1994$.

198. Tavares-Murta BM, Cunha FQ, Ferreira SH. Differential production of nitric oxide by endotoxin-stimullated rat and mouse neutrophils. Broz J Med Biol Res 29: 381-388, 1996. 
199. Buttery LDK, Evans TJ, Springdall DR, Carpenter A, Cohen J, Polak JM. Immunochemical localization of inducible nitric oxide synthase in endotoxin-treated rats. Lab Invest 71: 755-764, 1994.

200. Cook HT, Bune AJ, Jansen AS, Taylor GM, Loi RK, Cattell V. Cellular locallization of inducible nitric oxide synthase in experimental endotoxic shock in the rat. Clin Sci:87: 179-186, 1994.

201. Vallance P., Moncada S. Role of endogenous nitric oxide in septic shock. New Horizons 1: 77 $86,1993$.

202. Ochoa JB, Udekwu AO, Billiar TR, Curran RD, Cerra FB, Simmons RL, Peitzman AB. Nitrogen oxide levels in patients after trauma and during septic shock. Ann Supg 214:621-626, 1991.

203. Petros A, Bennett D, Vallance P. Effect of nitric oxide synthase imhibitors on hypotension in patients with septic shock. Lancet 338: 1557-1558, 1991.

204. Wright CE, Rees DD, Moncada S. Protective and pathological rolles of nitric oxide in endotoxin shock. Cardiovasc Res 26: 48-57, 1992.

205. Chamulitrat W, Skrepnik NV, Spitzer JJ. Endotoxin-induced oxidative stress in the rat small intestine: Role of nitric oxide. Shock 5: 217-222, 1996.

206. Morgan DM, Illei G. Polyamine-polyamine oxidase interaction: part of maternal protective mechanism against foetal rejection. Br Med J 280: 1295-1297, 1980.

207. Bowlin TL, McKown BJ, Sunkara PS. Omithine decarboxylase induction and polyamine biosynthesis are required for the growth of interleukin-2 and interleukin-3 dependent cell lines. Cell kmmunol 98: $341-350,1986$.

208. Bowlin TL, McKown BJ, Babcock GF, Sunkara PS. Intracellular polyamine biosynthesis is required for interleukin-2 responsiveness during lymphocyte mitogenesis. Cell Immunol 106: $420-427,1987$.

209. Bowlin TL, McKown BJ, Sunkara PS. Increased ornithine decarboxylase activity and polyamine biosynthesis are required for optimal cytolytic T lymphocyte induction. Cell Immunol 105: 110117,1987 .

210. Bowlin TL, McKown B., Sunkara PS. The effect of alpha-difluoromethylornithine, an inhibitor of polyamine biosynthesis, on mitogen-induced interleukin-2 production. Immunopharmacol 13 : 1.43-147, 1987.

21. Flescher E, Bowlin TL, Talal NJ. Polyamine oxidation down-regulates IL-2 production by human peripheral blood mononuclear cells. J Immunol 142: 907-912, 1989.

212. Elitsur Y. Strom J, Luk GD. Inhibition of ornithine decarboxylase activity decreases polyamines and suppresses DNA synthesis in human colonic lamina propria lymphocytes. Imminophamacol 25: 253-260, 1993.

213. Labib RS, Tomasi TB. Enzymatic oxidation of polyamines. Relationship to immunosuppressive properties. Eur J Immunol 1. 1: 266-269, 1981.

214. Byrd WJ, Jacobs DM, Amoss MS. Synthetic polyamines added to cultures containing bovine sera reversibly inhubit in vitro parameters of immunity. Nature 267:621-623, 1977.

215. Quan CP. Roux C, Pillot J, Bouvet JP. Delineation between $T$ and $B$ suppressive molecules from human seminal plasma: II. Spermine is the major suppressor of T-lymphocytes in witro. Am $J$ Reprod Inwumol 22: 64-69, 1990.

216. Thomas T, Gunnia UB, Yurkow EJ, Seibold JR, Thomas TJ. Inhibition of calcium signalling in murine splenocytes by polyamines: differential effects on CD4 and CD8 T-cells. Biochem $J 291$. $375-381,1993$.

217. Mills GB, Cheung RK, Grinstein S, Gelfand EW. Increase in cytosolic free calcium concentration is an intracellular messenger for the production of interleukin 2 but not for expression of the interleukin 2 receptor. J Immunol 134: 1640-1643, 1985.

218. Vliagoftis H, Boucher WS, Mak LL, Theoharides TC. Inhibition of mast cell secretion by oxidation products of natural polyamines. Biochem Pharmacol 43: 2237-2245, 1992. 
219. Ferrante A, Maxwell GM, Rencis VO, Allison AC, Morgan DML. Inhibition of the respiratory burst of human neutrophils by the polyamine oxidase-polyamine system. Int $d$ Immunopharmacol 8: 411-4417, 1986.

220. Ogata $K$, Nishimoto $N$, Uhlinger DJ, Igarashi $K$. Takeshita M, Tamura M. Spermine suppresses the activation of human neutrophil NADPH oxidase in cell-free and semi-recombinant systems. Biochem J 313: 549-554, 1996.

221. Zhang M, Caragine T, Wang H, Cohen PS, Botchkina G, Soda K. Bianchi M, Ulrich P* Cerami A. Sherry B, Tracey KJ. Spermine inhibits proinflammatory cytokine synthesis in human mononuclear cells: A counterregulatory mechanism that restrains the immune response. $J$ Exp Med 185: 1759-1768, 1997.

222. Wang $H$, Zhang M, Soda K, Sama A, Tracey KJ. Fetuin protects the fetus from TNF. Lancer $350: 861-862,1997$.

223. Mamont PS, Duchesne MC, Grove J, Bey P. Anti-proliferative properties of DL- $\alpha$ diflworomethylomithine in cultured cells. A consequence of the irreversible inhibition of omithine decarboxylase. Biochem Biophys Res Conmun 81: 58-66, 1978.

224. Quemener V, Blanchard Y, Chamaillard L, Havouis R, Cipolla B, Moulinoux JPH. Polyamine deprivation: A new tool in cancer treatment. Amicancer Res 14:443-448, 1994.

225. Seiler N, Sarhan S, Grauffel C, Jones $R$, Knödgen B, Moulinoux JP. Endogenous and exogenous polyamines in support of tumor growth. Cancer Res 50: 5077-5083, 1990.

226. Hessels J, Kingma AW, Muskiet FA, Sarhan S, Seiler N. Growth inhibition of two solid tumors in mice, caused by polyamine depletion, is not attended by alterations in cell-cycle phase distribution. Int I Cancer 48: 697-703, 1991.

227. Moulinoux JPH, Darcel F, Quemener V, Havouis R, Seiler N. Inhibition of the growth of U.25 human glioblastona in nudie mice by polyamine deprivation. Anticancer Res 11: 175-179, 1991.

228. Moulinoux JPH, Quemener V, Cipolla B, Guillé F, Havouis R, Martin C, Lobel B, Seiler N. The growth of MAT-LyLu rat prostatic adenocarcinoma can be prevented in vivo by polyamine deprivation. JUrol 146: 1408-1412, 1991.

229. Quemener V, Moulinoux JPH, Bergeron C, Darcel F, Cipolla B, Denais A, Havouis R, Martin C, Seiler N. Tumor growth inhibition by polyamine deprivation. In Polyamines in the Gastrointestinal Tract, Dowling RH, Fölsch UR and Löser C (Eds.), Klluwer Academic Press, Lancaster, UK, Dordrecht NL, pp. 375-385, 1992.

230. Chamaillard L, Quemener V, Havouis R, Moulinoux JP, Polyamine deprivation stimulates natural killer cell activity in cancerous mice. Anticancer Res 13: 1027-1034, 1993.

231. Thomas TJ, Gunna UB, Thomas T. Reversal of the abnormal development of T cell populations in the thymus of autoimmune MLR-lpr/lpr mice by a polyamine biosynthesis inhibitor. Autommunity $13: 275-283,1992$. 
$-42-$ 


\section{CHAPTER 2}

THE NEONATAL DEVELOPMENT OF INTRAEPITHELIAL AND LAMINA PROPRIA LYMPHOCYTES IN THE MURINE SMALL INTESTINE

Ter Steege JCA, Buurman WA, Forget PPh.

Developmental Immunology 5: 121-128, 1997 


\section{ABSTRACT}

During early neonatal life important changes occur in the gut. The intestine is challenged by both milk and a microbial flora. Later on, at weaning, the diet of mice changes from milk to pelleted food leading to changes in microbial contents. This period seems essential for a complete development of the mucosal immune system. We investigated the development of both intraepithelial (IEL) and lamina propria lymphocytes (LPL), from day 5 onwards, and every 5 days, up to day 30 after birth. IEL and LPL were isolated from the small intestine and the phenotype was assessed by FACS analyses, using antibodies for detection of T cell markers CD3, TCR $\alpha \beta$, TCR $\gamma \delta, C D 4, C D 8 \alpha, C D 8 \beta, C D 5, C D 18, C D 54$ and $C D 49 d$. Our data show a clear increase in the number of LPL just before weaning, while the number of IEL increased after day 15. A more mature pattern of membrane antigen expression of both IEL and LPL was observed at weaning. The adhesion molecules CD18, CD54 and CD49d, essential for cellular communication of lymphocytes, showed an expression peak at weaning. In conclusion, the mouse mucosal immune system develops during the first 3 weeks of neonatal life, leading to the formation of a more mature immune system at weaning.

\section{INTRODUCTION}

The gastrointestinal tract is one of the major sites of immunological challenge. Although a protective immune response against invading pathogenic micro-organisms is essential, the systemic immune response to foreign dietary antigens, must be suppressed. Therefore, in the intestine, perhaps more than in any other organ, immune reactivity must be tightly regulated. The question as to how the mucosall immune system categorizes antigens and selects a particular response is central to this process but remains largely unanswered (1-3).

The mucosal immune system mainly consists of two compartments with their own lymphocyte population separated by a basal membrane, the epithelium containing the intraepithelial lymphocytes (IEL) and the lamina propria containing the lamina propria lymphocytes (LPL). LPL are phenotypically and functionally similar to peripheral lymphocytes (4). Peyer's patches lymphocytes are considered as peripheral lymphocytes. Characterization of IEL has revealed a phenotypic and functional heterogeneity that is further observed only in the thymus (5).

Several lines of evidence have led to the conclusion that $T$-cell lymphopoiesis occurs within the intestinal epithelium, a tissue that shares the same endodermic origin as the thymus (5-10). These data are in accordance with data that showed that, in mice, mRNA for Recombination Activating Gene 1 (RAG1) was present in $\mathrm{CD}^{-}$IEL, suggesting that rearrangement of the gene to produce a functional TCR occurs in the 
Intestine (11). Recently, RAGI and RAG2 gene expression was also detected in the human intestine (12).

Intestinal maturation seems partly regulated by internal triggers $(6,10,13-14)$ but complete maturation of the intestinal immune system seems to occur only after the intestine is challenged postnatally with both microbial and nutritional antigens (14). Maturation at weaning is also characterized by biochemical and morphological changes in the small intestine adapting the intestine to changes in the diet from milk to pelleted food (15).

Detailed data on the mucosal immune system in mice have only been reported at the age of $1,3,28$ days (16) and in adult mice $(6-7,17)$. In the present study we aimed at describing the mouse mucosal immune system ontogenesis by analyzing in detail the gut lymphocytes populations from day 5 onwards, and every 5 days, up to day 30 .

\section{MATERIAL AND METHODS}

\section{Reagents and Antubodies}

EDTA, dithiothreitol (DTT), collagenase (Type IV) and bovine serum albumin (BSA) were obtained from Sigma (St. Louis, MO). Medium consisted of RPMI640 (Gibco BRL, Paisley, U.K.) supplemented with $10 \%$ heat-inactivated fetal calf serum (Hyclone, Logan, UT), $100 \mathrm{U} / \mathrm{ml}$ penicillin, $100 \mu \mathrm{g} / \mathrm{ml}$ streptomycin, $200 \mathrm{mM}$ glutamine (Gibco BRL) and $0.1 \mathrm{mg} / \mathrm{ml}$ DNAse (Sigma). Percoll was obtained from Pharmacia (Uppsala, Sweden), biotin-X-NHS was obtained from Calbiochem (La Jolla, CA) and streptavidin phycoerythrin (RPE) from Caltag (SO San Francisco, CA).

Antibodies were obtained from hybridoma lines GK1.5 (rat anti-mouse CD4, IgG2b) (18), 53-6.72 (rat anti-mouse CD8 $\alpha, \operatorname{IgG2a}$ ) (19), YN1/1.74 (rat anti-mouse CD54 (ICAM), IgG2a) (20), R1-2 (rat anti-mouse CD49d ( $\alpha 437$, LPAM), IgG2b) (21), 2E6 (hamster anti-mouse CD18, IgCi) (22), H57-597 (hamster anti-mouse TcR $\beta$. $\operatorname{lgG}$ ) (23) all from the ATCC (Rockville, MD). Hybridoma cell line $145-2 \mathrm{Cl} \rrbracket$

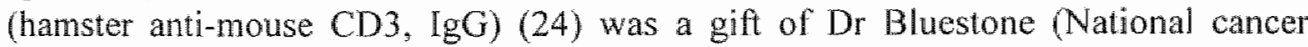
institute, Bethesda, MD). Hybridoma GL3 (hamster anti-mouse TcR $y, \operatorname{IgG}$ ) (17) was kindly provided by Dr. L. Lefrancois (UNCONN Health Center, Farmington, CT). Anti-mouse CD8B (Yb 156.7.7, IgG2b) (25) and CD5 (YTS 121.5.2, IgG2b) (26) antibodies were a gift of Dr. S.P. Cobbold (Department of Pathology, Oxford, UK). Monoclonal antibodies (mAbs) were purified from culture supernatant by affinity chromatography. All antibodies were conjugated with biotin.

\section{Animals}

Swiss mice were obtained from Charles River Breeding Laboratories (Heidelberg, FRG). They were maintained on a standard laboratory diet and wore allowed free 
access to water. Guidelines of the Committee for Care and Use of Laboratory Animals from the Maastricht University were followed throughout. Litters were reduced to 10 pups per lactating mother, with free access to the nipples. The mice were weaned on day 20 . From day 15 onwards they start to eat foodpellets.

\section{Isolation of intestinal lymphocytes}

IEL and LPL were isolated using a modification of the method of Van der Heijden and Stok (27). In short, the small bowel was immediately removed from the stomach to the appendix. The intestine was flushed with PBS $\left(4^{\circ} \mathrm{C}\right)$ to remove faecal content and trimmed of fat, mesentery and Peyer's patches. Subsequently, the intestine was cut longitudinally, washed twice with PBS supplemented with $50 \mathrm{mM}$ glucose and cut in pieces of $0.5-1.0 \mathrm{~cm}$. IEL were isolated by incubation of the pieces of intestine in an EDTA/DTT solution for 15 min after which the supernatant was removed and the pieces were incubated in medium for $30 \mathrm{~min}$ at $37^{\circ} \mathrm{C}$. Next, the cell suspensions obtained were passed over a $50 \mu \mathrm{m}$ nylon gauze, centrifuged $(5 \mathrm{~min}, 370 \mathrm{~g}$ ) and resuspended in medium. The pieces of the intestine remaining on the nylon gauze were used for isolation of LPL by incubation in $20 \mathrm{ml}$ medium supplemented with 7,000 Units collagenase in a shaking waterbath at $37^{\circ} \mathrm{C}$ for $30 \mathrm{~min}$. This procedure was repeated once after the supernatant with the freed cells was removed. Next, the cell suspensions obtained were passed over a $50 \mu \mathrm{m}$ gauze, pelleted and resuspended in medium. A further purification of the lymphocytes (both IEL and LPL) was obtained by density gradient centrifugation of the obtained epithelial and lamina propria cell fractions, using a discontinuous percoll gradient. The viability was always over $90 \%$ as assessed by trypan blue exclusion. Cells were kept at $4^{\circ} \mathrm{C}$ until further processing.

\section{FACS analysis}

For FACS analysis of young animals ( $<$ day 20 ), intestines of 3 mice were pooled to obtain sufficient numbers of lymphocytes for FACS staining. Cells $\left(10^{5}\right.$ in $\left.0.1 \mathrm{ml}\right)$ were washed with PBS containing 0.1\% BSA and azide and incubated with mAb at the appropriate dilution $(1-10 \mu \mathrm{g} / \mathrm{ml})$ in PBS containing $0.1 \%$ BSA and azide for $1 \mathrm{hr}$ at $4^{\circ} \mathrm{C}$. Subsequently, the cells were washed 3 times with cold PBS containing $0.1 \%$ $\mathrm{BSA}$ and azide $\left(4^{\circ} \mathrm{C}\right)$ and incubated with streptavidin-phycoerythrin for $1 \mathrm{hr}\left(4^{\circ} \mathrm{C}\right)$. After this incubation the cells were washed 3 times and analyzed using a FACSsort equipped with the LYSES II program (Becton and Dickinson, Sunnyvale, CA). Cells were gated out using forward versus side scatter to exclude aggregates, dead cells or debris. Fluorescence intensity was expressed as mean channel number. 


\section{RESULTS}

\section{Development of IEL}

The number of IEL and CD3 ${ }^{+}$IEL in the small intestine at the ages studied are shown in Figure 1 . On day 5 low numbers $\left(2.6 \times 10^{5}\right)$ of IEL were isolated per small intestine of which only $17.5 \%$ were $\mathrm{CD3}^{+}$(see also Figure 2). From day 5 onwards, the number of IEL increased, paralleled by a significant $(p<0.01)$ increase in the percentage of $\mathrm{CD}^{*}$ cells on day 15 . Levels of $90 \% \mathrm{CD}^{*}$ cells were reached on day 25 and stabilized thereafter. Before weaning (day 20) the intensity of the CD3 expression was low, however, from day 25 onwards a large $\mathrm{CD} 3^{\text {high }}$ and a small $\mathrm{CD} 3^{\text {low }}$ population was detected (Figure 3).

Figure 1. Total number and number of $C D 3^{+}$IEL (A) and LPL (B) recovered per small intestine increased during maturation. Open bars represent the number of $\mathrm{CD}^{+}$positive cells. Hatched bars represent the total amount of cells. Data are given as mean $\pm S E M$ of 6 experiments.
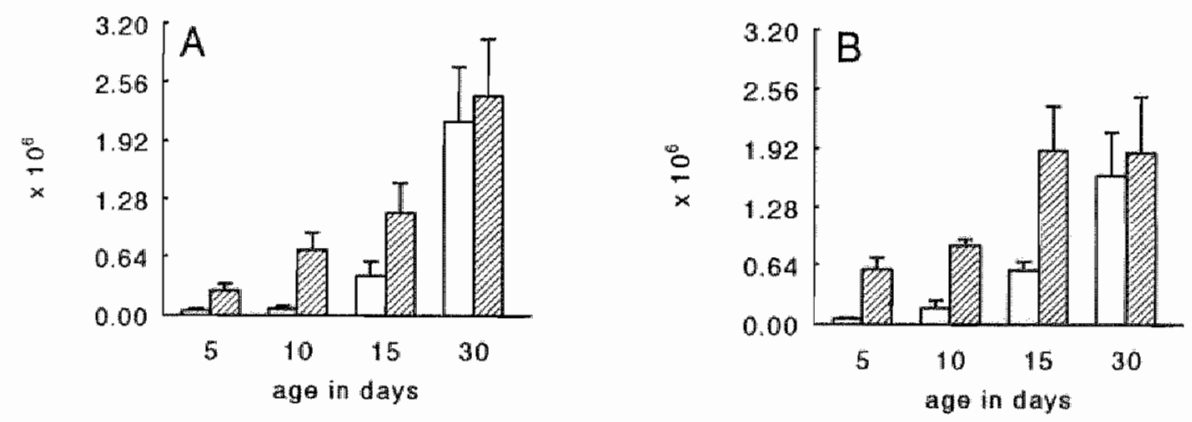

Next we studied the TCR gene usage during development. The data on TCR expression revealed that both number and percentage of TCR $\gamma \delta^{+}$thymic-independent IEL were very low shortly after birth (Figure 2). The percentage TCR $\gamma^{*}{ }^{+}$cells increased from day 10 onwards to $50 \%$ on day 20 . From day 15 onwards also the TCR $\alpha B$ expression increased, to reach $50 \%$ on day 25 .

In adult mice, the CD8 phenotype is characteristic of IEL. CD8 can consist of the thymus independent $\alpha \alpha$ homodimeric or the $\alpha \beta$ heterodimeric thymus dependent form. The number of CD $8 \alpha^{+}$IEL increased rapidly from day 15 onwards to reach adult 
levels on day 25 . Double staining with CD8B revealed that on day 15 most of the CD8 cells consisted of a CD $8 \alpha \beta$ phenotype and that on day 30 the thymic independent CD8 $\alpha \alpha$ cells were more prominent (Figure 2).

Figure 2. Phenotypic characierization of IEL during development. Data are given as percentage of total number of IEL recovered. At each time point the mean $\pm S E M$ of 6 experiments is given.
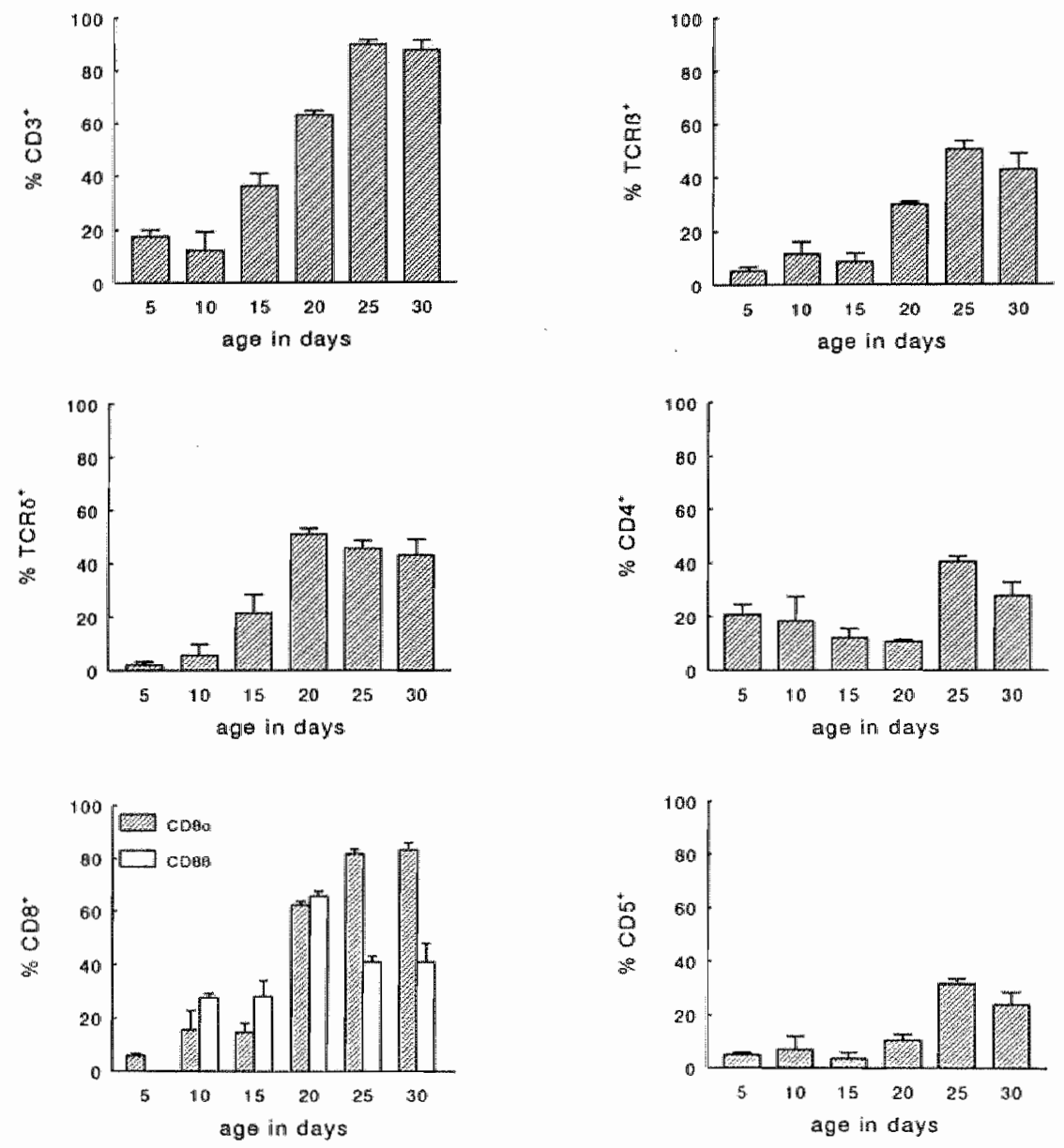
A minority of the IEL carried the thymus-dependent $\mathrm{CD} 4^{+}$phenotype. The percentage of $\mathrm{CD} 4^{+}$cells increased from $11 \%$ on day 20 to $30 \%$ on day 30 (Figure 2 ). To further analyze the thymus dependent population of IEL we assessed CD5 membrane expression (Figure 2). CD5 expression data revealed that the number of $\mathrm{CD}^{+}$cells was very low $(<7 \%)$ until day 20 , while thereafter the percentage $\mathrm{CD} 5^{+}$cells started to increase to reach $30 \%$ on day 25 .

Figure 3. FACS analyses show an increase in intensity of $C D 3$ expression on IEL $(A, B, C, D)$ and $L P L(E, F, G, H)$ during maturation of the mucosal immune system. The $X$-axis gives the relative fluorescence intensity and the Y-axis the number of cells. Similar results were obtained in 6 experiments.
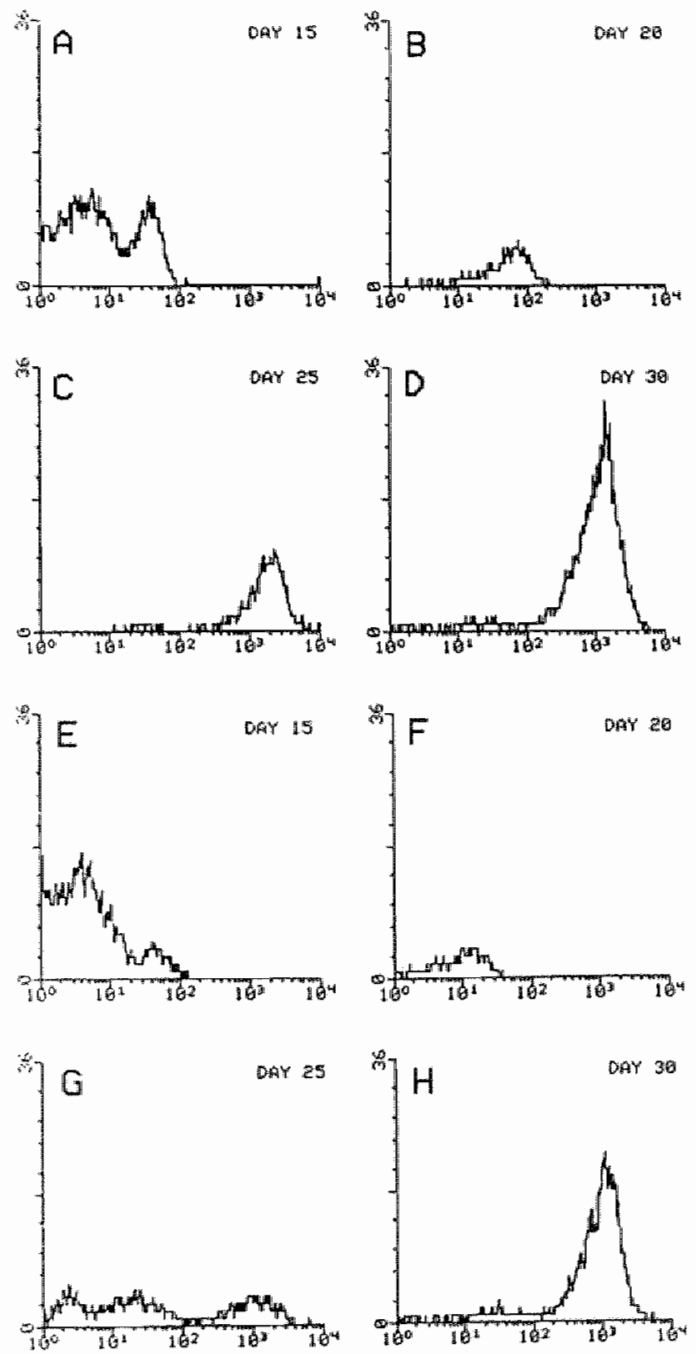


\section{Development of LPL}

The population of LPL during the neonatal period was studied, simultaneously, in the same animals. On day 5 , the number of LPL $\left(5.8 \times 10^{5}\right)$ was higher than the number of IEL (Figure1) but the percentage of CD3 was similarly low (12\%, Figure 4). The percentage of $\mathrm{CD}^{*}$ LPL increased rapidly from day 5 onwards to reach $90 \%$ on day 30. Similar to the intensity of CD3 expression in IEL, the intensity of the LPL CD3 expression increased with aging (Figure 3 ).

Figure 4. Phenotypic characterization of LPL during development. Data are given as percentage of total number of LPL recovered. At each time point the mean $\pm S E M$ of 6 experiments is given.
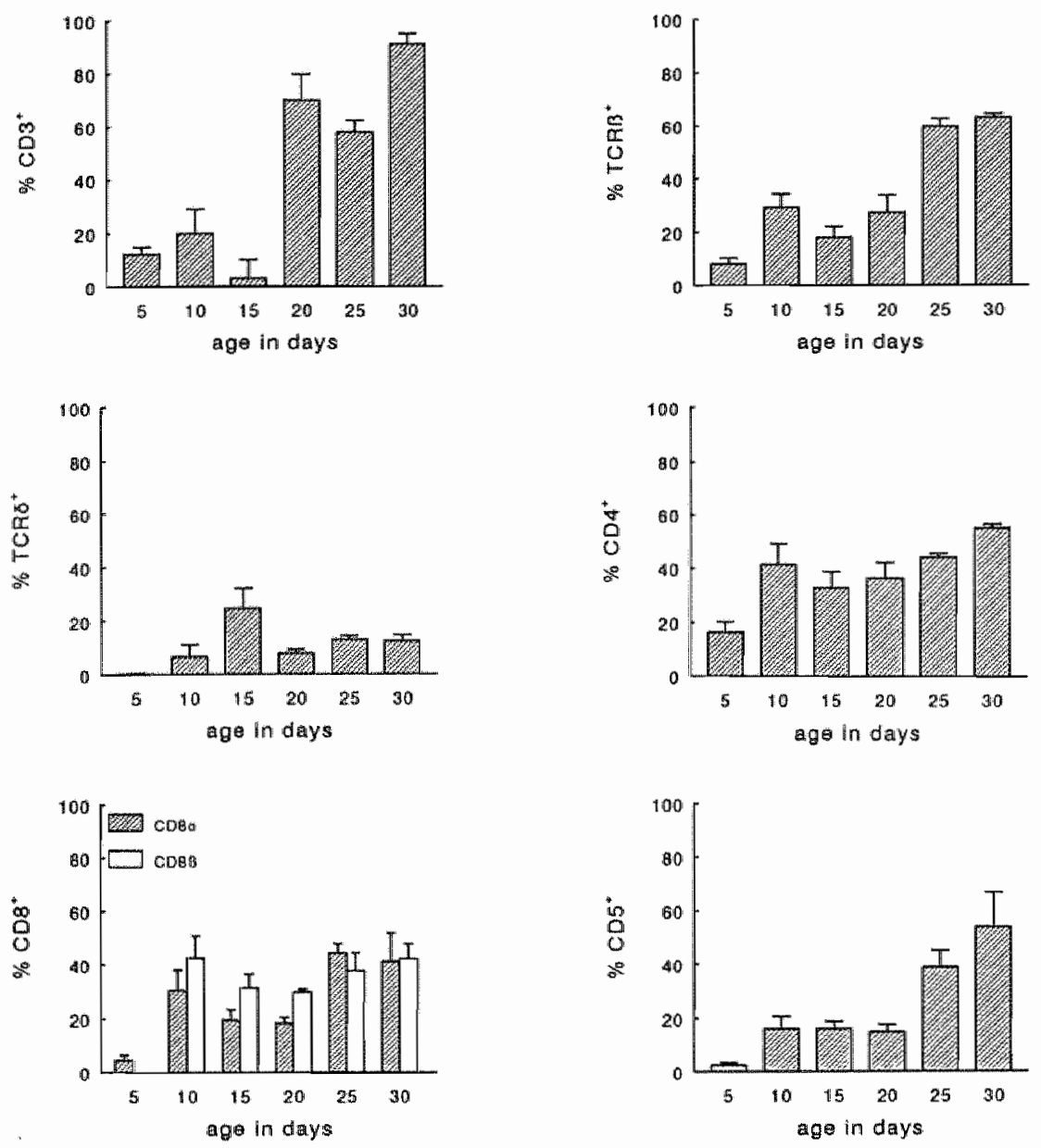
Assessment of the TCR type usage by LPL revealed an almost exclusive TCRaB expression, similar to that of peripheral $\mathrm{T}$ cells (Figure 4). No detectable TCR $\gamma \delta$ expression was found in the lamina propria on the fith postnatal day. A low percentage (1.0-15\%) of TCR $\gamma \delta$ was detected from day 10 onwards. In contrast to low TCR $\gamma \delta$ expression, usage of TCR $\alpha B$ increased rapidly to $60 \%$ on day 30.

In adult animals, the ratio of CD8 suppressor/cytotoxic to CD4 helper phenotype in the LPL population is similar to that of the peripheral $T$ cell population, being approximately $1: 1$ (3). The percentage of CD8 ${ }^{+}$LPL increased from day 5 rapidly to reach levels of $50 \%$ on day 25 . Double staining for $C D 8 \alpha$ and $C D 8 B$ revealed that the majority of the LPL expressed the thymus dependent CD $8 \alpha \beta$ heterodimeric form (Figure 4). The percentage of CD $4^{+}$LPL reached levels of $40 \%$ on day 10 (Figure 4 ). CD5 expression on LPL showed an increase from day 20 onwards to $54 \%$ CD 5 LPL on day 30 (Figure 4).

\section{Adhesion molecule expression of mucosal lymphocytes}

Adhesion molecules play an important role in cellular communication and migration of lymphocytes and their micro-environment. In this perspective, we studied the kinetics of the expression of the adhesion molecules CD18, CD54 and CD49d during early neonatal life. The data on CD18 expression by IEL showed, that $25 \%$ of the IEL express this adhesion molecule up to day 25 when the expression increased to $51 \%$ with a subsequent decrease to $35 \%$ on day 30 (Figure 5). CD54 IEL were detected before weaning $(20 \%)$ and increased to $40 \%$ after weaning. The homing receptor for the Peyer's Patches, CD49d was expressed on 20\% of the IEL and increased to $40 \%$ on day 25.

The micro-environment and the origin of LPL differs substantially from IEL; it was therefore expected that the cellular expression of adhesion molecules would differ from that of IEL. CD18 expression on the LPL increased from day 5 onwards. A peak of $68 \%$ CD 18 LPL was found at the age of 20 days, which subsequently decreased to $44 \%$ on day 30 . Similarly, the percentage of CD $44^{*}$ LPL increased from day 5 to reach $61 \%$ on day 20 followed by a decrease to approximately $45 \%$ on day 30 . The fraction. of CD49d LPL was $16 \%$ on day 5 and increased to $67 \%$ at the age of 25 days. A decrease to $52 \%$ was found at the age of 30 days (Figure 5). From day 15 onwards, the level of expression for all the adhesion molecules was in general higher on the L.PL population when compared to IEL. 
Figure 5. Adhesion molecule expression by $I E L(A)$ and $L P L(B)$ during developmen. Data are given as percentage of total IEL and LPL recovered. At each time point the mean \pm SEM of 6 experiments is given.
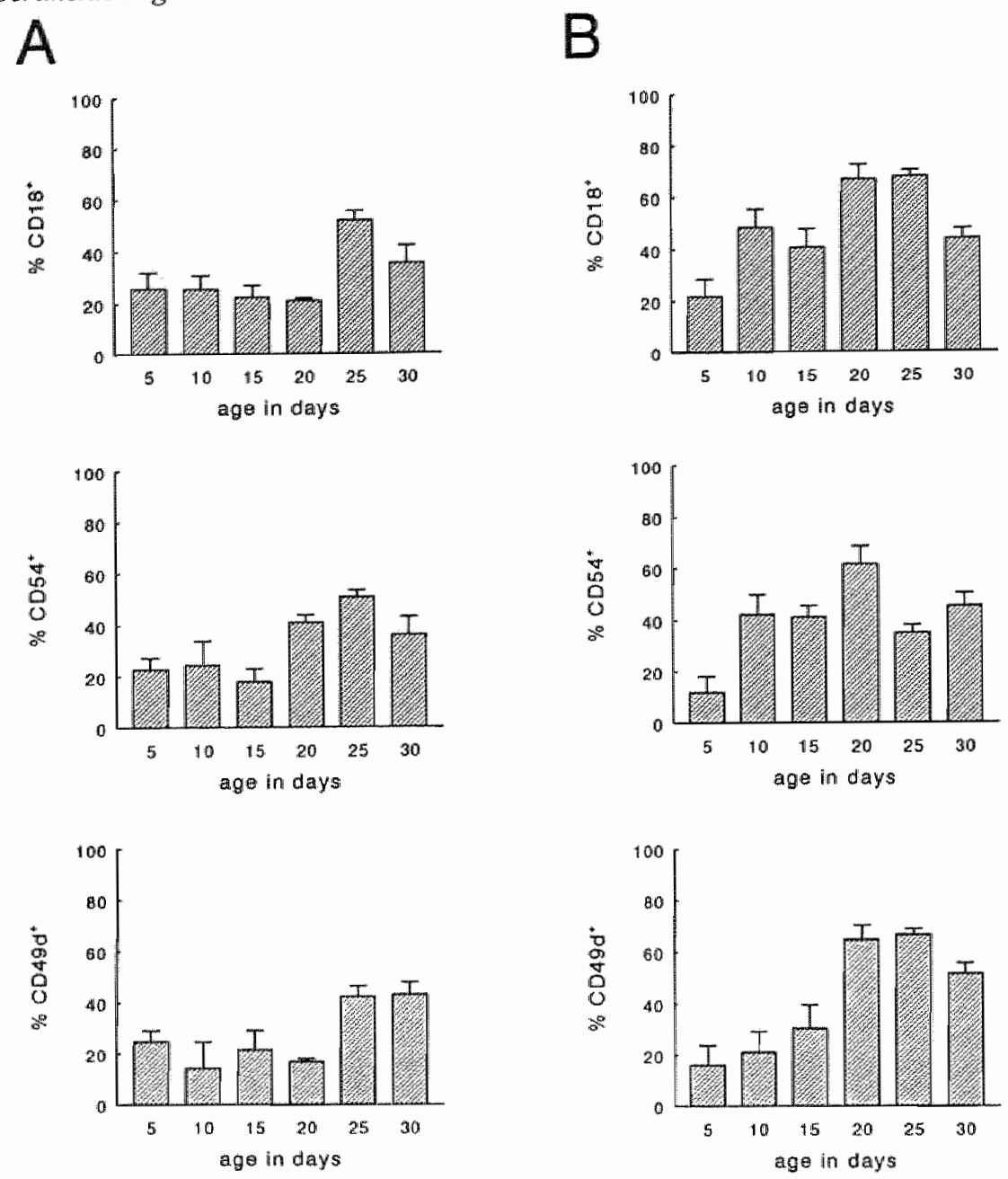

\section{DISCUSSION}

The data presented show that the murine intestine contains very low numbers of IEL and LPL shortly after birth. Similarly to the results in mice, the number of intestinal lymphocytes in young rats and pigs (5 days) were found to be $10 \%$ of that in adult animals (28-29). De Geus and Rozing (16) reported a majon increase in number of $\mathrm{CD}^{+}$IEL and LPL between the first and $28^{\text {th }}$ postnatal day. We show that the major increase in IPL takes place before weaning (between day 10 and 15) in contrast to the increase in IEL numbers which takes place after day 15. 
Another characteristic of mucosal lymphocytes in young mice is that both the number and the intensity of membrane antigen expression are very low. Consequently, during development, differentiation was characterized by both an increase in the number and intensity of membrane antigen expression.

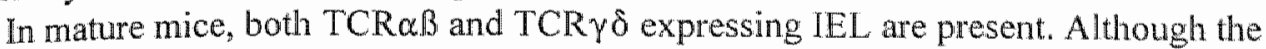
extent of TCR $\alpha \beta$ and TCRYó expression is known to be strain dependent (30), the presence of a large fraction of TCR $\gamma \delta^{+}$cells, as detected in our experiments, is characteristic of murine IEL (4). On day 5, a very small percentage of CD3 ${ }^{+}$, TCR $\alpha B^{+}$ and TCR $\gamma \delta^{+}$was detected which increased in parallel with the increase in number of IEL. Interestingly, the increase in the percentage of TCR $\gamma{ }^{*}$ IEL was detected on day 15 before the increase in TCR $\alpha 3^{+}$IEL which occurred at weaning (day 20). Our findings fits the hypothesis that TCR $\alpha \beta$ IEL, in contrast to TCR $\gamma \delta$, need antigen stimulation for their development in the intestinal epithelium since these cells seem to be stimulated by the change in diet occurring at weaning $(14,29,31-32)$.

Next to the increase in the percentage of CD ${ }^{+}$IEL, which started on day 20 , weaning also affected CD8 expression. Whereas the thymus dependent CD $8 \alpha \beta$ form was more prominently expressed before weaning, the thymus independent CD $\alpha \alpha \alpha$ form increased rapidly at weaning suggesting that luminal antigen stimulation favor the development of the thymus independent CD $8 \alpha \alpha$ form.

CD4 and CD5 expression increased somewhat later than CD8, in line with the observations of Lyscom and Brueton (28) in rat. From day 25 onwards, the total percentage of $\mathrm{CD}^{*}$ and $\mathrm{CD} 4^{+}$exceeded the percentage of $\mathrm{CD} 3^{+} \mathrm{IEL}$, indicating the presence of double positive (CD8 ${ }^{+} \mathrm{CD} 4^{+}$) IEL. Mosley et al. (33) reported that approximately $50 \%$ of the CD4 $4^{*}$ EL simultaneously expressed CD8. Both CD4 and CD5 are characteristic of thymus-dependent IEL. Their expression pattern was rather similar to that of TCR $\alpha \beta^{*}$ IEL.

The LPL population is known to be phenotypically and functionally different from IEL. LPL are thymus-dependent and are easily stimulated via the $T$ cell receptor (TCR) in contrast to IEL $(4,30,34)$. TCR expression of LPL revealed a low expression (10\%) of TCR $\gamma \delta$ and a high expression of the $\alpha B$ TCR in 30 days old mice. This TCR phenotype is characteristic of peripheral lymphocytes (3).

Adult CD4 expression was already reached on day 10. CD8 $\alpha B$ and CDS LPL were also present at this age but the increase to adult levels was found at weaning. In 30 days old mice, the LPL CD8 suppressor/cytotoxic and CD4 helper expression is about $1: 1$, which is characteristic for peripheral $\mathrm{T}$ cells (3).

Migration of lymphocytes to the intestine, mediated by adhesion molecules, plays an essential role in the development of the intestinal immune system $(21,35)$. From this perspective, we investigated the development of the expression of the adhesion molecules CD18, CD54 and CD49d during neonatal life.

The expression of the $\beta_{2}$ integrin CD18 was low on murine $1 E L$ peaking on day 25 . In contrast to IEL, we found a much higher expression on murine LPL, similar to what has been reported in humans (36-37). CDS4 expression on IEL was about 20\% and 
increased around weaning in parallel with an increase in the number of IEL, probably indicating IEL activation. CD54 on LPL also showed an expression peak around weaning, albeit earlier than for IEL.

As expected, only a small proportion of the IEL expressed the $\alpha 4 \beta 7$ integrin CD $49 \mathrm{~d}$, homing receptor for the Peyers Patches $(21,38)$, indicating that a small population of IEL migrated from the periphery. CD $49 \mathrm{~d}$ expression on LPL increased rapidly around weaning, suggesting an increase of LPL homing to the Peyers Patches. Boll and Reimann (39) reported similar levels of CD49d (LPAM) expression in adult mice and Trejdosiewicz (40) in humans.

In conclusion, our data show that not only the phenotype of IEL and LPL are different, but also the kinetics of changes in phenotype during development are different. LPL are present in the intestine early after birth and are almost completely differentiated before weaning in contrast to IEL which develop completely after weaning (day 20). The peak in expression of adhesion molecules around weaning indicate an important role during the development of the mucosal immune system especially in the lamina propria since, adhesion molecule expression was higher for LPL than for IEL.

\section{Acknowledgement}

This work was supported by a Grant from Nutricia Research Foundation (S155715), The Hague, the Netherlands.

\section{REFERENCES}

1. Strobel S. Immunologically mediated damage to the intestinal mucosa. Acta Paediatr Scand Suppl 365: 46-57, 1990 .

2. Trejdosiewicz LK. What is the role of human intestinal intraepithelial lymphocytes ? Clin Exp Immunol 94: 395-397, 1993.

3. Stokes $\mathrm{CR}, \mathrm{Bailey} \mathrm{M}$, Wilson $\mathrm{AD}$. Immunology of the porcine gastrointestinal tract. Veterinary Immumol and Immutopath 43: 143-150, 1994.

4. Guy-Grand D, Cerf-Bensussan N, Malissen B, Malassis-Seris M, Briottet C, Vassalli P. Two gut intraepithelial $\mathrm{CD}^{-1}$ lymphocyte populations with different $\mathrm{T}$ cell receptors: A role for the gut epithelium in T cell differentiation. I Exp Med 173: 471-481, 1991.

5. Poussier $\mathbb{P}$, Julius M. Intestinal intraepithelial lymphocytes: The plot thickens. I Exp Med 180: $1185-1189,1994$.

6. Ferguson A, Partott DM. Growh and development of "antigen-free" grafts of foetal mouse intestine. J Pathol 106: 95-101, 1972.

7. Bandeira A, Itohara $\mathrm{S}$, Bonneville $\mathrm{M}$, Burlen-Defranoux $\mathrm{O}$, Mota-Santos $\mathrm{T}$, Coutinho $\mathrm{A}$, Tonegawa $S$. Extrathymic origin of intestinal intraepithelial lymphocytes bearing T-cell antigen receptor $\gamma \delta$. Proc Natl Acad \$ci 88: 43-47, 1991.

8. Rocha B, Vassalli P, Guy-Grand D. The V $\beta$ repertoire of mouse gut homodimeric $\alpha \mathrm{CD}^{*}$ intraepithelial $T$ cell receptor $\alpha / \beta^{+}$lymphocytes reveals a major extrathymic pathway of $T$ cell differentiation. J Exp Med 173: 483-486, 1991 . 
9. Rocha B* Vassalli P, Guy-Grand D. Thymic and extrathymic origins of gut intraepithelial Jymphocyte populations in mice. I Exp Med 180: 681-686, 1994.

10. Mosley RL, Klein JR. Peripheral engrafument of fetal intestine into athymic mice sponsors 11 cell development: Direct evidence for thymopoietic function of murine small intestine. $J$ Exp Med 176: $1365-1373,1992$.

11. Guy-Grand D, Vanden Broecke C, Briottet C, Malassis-Seris M, Selz F, Vassalli P. Different expression of the recombination activity gene RAG-1 in various populations of thymocytes, peripheral $T$ cells and gut thymus-independent intraepithelial lymphocytes suggests two pathways of T cell receptor rearrangement. Eur J Immusol 22: 505-510, 1992.

12. Lynch $S$, Kelleher D, McManus $R$, O Farrelly $C$. RAG1 and RAG2 expression in human intestinal epithelium: evidence of extrathymic T cell differentiation. Eur J Immunol 25: 1143-1147, 1995.

13. Diamond JM. Hard-wired local triggering of intestinal enzyme expression. Nature 324: 408, 1986.

14. Bandeira A, Mota-Santos T, Itohara S, Degermann S, Huesser C, Tonegawa S, Coutinho A. Localization of $\gamma / \delta \mathrm{T}$ cells to the intestinal epithelium is independent of normal microbial colonization. J Exp Med 172: 239-244, 1990.

15. Henning $\mathrm{S}$, Kretchmer $\mathrm{N}$. Development of intestinal function in mammals. Enzyme 15:3-23, 1973.

16. De Geus $B$, Rozing J. Co-expression of TCR-B and TCR- $\delta$ chains on intestinal lamina propria lymphocytes during neonatal development in euthymic and athymic mice. In thesis, Differentiation and characterization of murine intestinal intraepithelial lymphocytes. Pasmans BV, 's-Gravenhage, the Netherlands, pp. $90-109,1992$.

17. Goodman T, Lefrancois L. Intraepithelial lymphocytes. Anatomical site, not T cell receptor form, dictates phenotype and function. $J \operatorname{Exp} M e d 170: 1569-1581,1989$.

18. Dialynas DP, Wilde DB, Marrack P, Pierres A, Wall KA, Harvan W, Otten G, Loken MR, Pierres $M$, Kappler J, Fitch FW. Characterization of the murine antigenic determinant, designated L $3 \mathrm{~T} 4 \mathrm{a}$, recognized by monoclonal antibody GK1.5: Expression of L3T4a by functional T cell clones appears to correlate primarily with class II MHC antigen reactivity. Immunological Rev 74: 29-56, 1983.

19. Ledbetter JA, Herzenberg LA. Xenogeneic monoclonal antibodies to mouse lymphoid differentiation antigens. Immunological Rev 47; 63-90, 1979.

20. Takei $F$. Inhibition of mixed lymphocyte response by a rat monoclonal antibody to a novel murine lymphocyte activation antigen (Mala-2). J Irmmol 134: 1403-1407, 1985.

21. Holzmann B, McIntyre BW, Weissman $\mathbb{I L}$. Identification of a murine peyer's patch-specific lymphocyte homing receptor as an integrin molecule with an $\alpha$ chain homologous to human VLA4a. Cell 56: 37-46, 1989 .

22. Metlay JP, Witmer-Pack MD, Agger R, Crowley MT, Lawless D, Steinman R.M. The distinct leukocyte integrins of mouse spleen dendritic cells as identified with new hamster monoclonal antibodies. J Exp Med 171: 1753-1771, 1990.

23. Kubo RT, Born W, Kappler JW, Marrack P, Pigeon M. Characterization of a monoclonal antibody which detects all murine $\alpha$ I T cell receptors. I Immunol 142: 2736-2742, 1989.

24. Oberdan L, Foo M, Sachs DH, Samelson LE, Bluestone JA. Identification of a monoclonal antibody specific for a murine T3 polypeptide. Proc Nat Acad Sci 84: 1374-1378, 1987.

25. Qin $S$, Cobbold $S$, Benjamin $R$, Waldmann $H$. Induction of classical transplantation tolerance in the adult. J Exp Med 169: 779-794, 1989.

26. Cobbold SP, Jayasuriya $A$, Nash A, Prospero TD, Waldmann H. Therapy with monoclonal antibodies by elimination of T-cell subsets in wivo. Nature $312: 548-551,1984$.

27. Van der Heijden PJ, Stok W. Lmproved procedure for the isolation of functionally active lymphoid cells from the murine intestine. J Immunol Methods 103:161-167, 1987.

28. Lyscom N, Brueton MJ. The development of intraepithelial and Peyer's patch lymphocyle sulbtypes in the small intestine of newborn rats. Clin Exp Immunol 54: 158-162, 1983. 
29. Rothkotter $\mathrm{H}_{\mathrm{z}}$ Kirchhoff $\mathrm{T}$, Pabst R. Lymphoid and non-lymphoid cells in the epithelium and lamina propria of intestinal mucosa of pigs. Gut 35:1582-1589, 1994.

30. Poussier $P$, Jullus $M$. Thymus independent $T$ cell development and selection in the intestinal epithelium. Annu Rev Immunol 12: 521-553, 1994.

31. De Geus B, Shultz LD, van den Enden M, Coolen C, Rozing J. Analysis of intestinal intraepithelial lymphocytes in athymic (nude) and scid mice. In Advances in Mucosal Immunology. Mc Donalld TT et al. (Eds.), Kluwer academic publishers, Dordrecht/Boston/London, pp. 71, 1990.

32. Machado CSM, Rodrigues MAM, Maffei HVL. Assessment of gut intraepithelial lymphocytes during late gestation and the neonatal period. Biol Neonate 66: 324-329, 1994.

33. Mosley RL, Styre D, Klein JR. CD4 $4^{+} \mathrm{CD} 8^{+}$murine intestinal intraepithelial lymphocytes. $/ \mathrm{m}$ t Immunol 2: 361-365, 1990.

34. Poussier $\mathbb{P}_{*}$ Edouard P, Lee $C$, Binnie $M$, Julius $M$. Thymus-independent development and negative selection of $T$ cells expressing $T$ cell receptor $\alpha / B$ in the intestinal epithelium: evidence for distinct circulation patterns of gut- and thymus-derived T lymphacytes. J Exp Med 176: 187$199,1992$.

35. Duijvestijn A, Hamann A. Mechanisms and regulation of lymphocyte migration. Immunology Today 10:23-28, 1989 .

36. Jarry A, Cerf-Bensussan N, Brousse N, Selz F, Guy-Grand D. Subsets of $\mathrm{CD}^{*}$ (T cell receptor $\alpha / \beta$ or $\gamma / \delta$ ) and $C D 3^{-}$lymphocytes isolated from normal human gut epithelium display phenotypical features different from their counterparts in peripheral blood. Eur I Immunol 20: $1097-1103,1990$.

37. Smart CJ, Callabrese A, Oakes DJ, Howdle PD, Trejdosiewicz LK. Expression of the LFA-1 B integrin (CDIla/CDI8) and ICAM-1 (CD54) in normal and coeliac small bowel mucosa. Scand $J$ Immunol 34: 299-305, 1991.

38. Boll G, Rudolphi A, Spieß S, Reimann I. Regional specialization of intraepithelial $T$ cells in the murine small and large intestine. Scand J Immunol 41: 103-113, 1995.

39. Boll $G$, Reimann $J$. Lamina propria $T$ cell subsets in the small and large intestine of euthymic and athymic mice. Scand J Immunol 42: 191-201, 1995.

40. Trejdosiewicz LK. Intestinal intraepithelial lymphocytes and lymphoepithelial interactions in the human gastrointestinal mucosa. Imwunol Let 32: 13-20, 1992. 


\section{CHAPTER 3}

SPERMINE INDUCES MATURATION OF THE IMMATURE INTESTINAL IMMUNE SYSTEM IN NEONATAL MICE

Ter Steege JCA, Buurman WA, Forget PPh.

Journal of Pediatric Gastroenterology and Nutrition 25: 332-340, 1997 


\section{ADSTRACT}

In mice, immunological adaptation of the gut to microbial and nutritional antigens occurs at weaning in parallel with biochemical and morphological maturation. Because oral administration of spermine to neonatal rats has been shown to induce biochemical and morphological maturation, we investigated whether spermine also affects maturation of the mucosal immune system. Swiss mice of 7,12 and 27 days were given spermine orally $(0.5 \mu \mathrm{mol} / \mathrm{g}$ body weight) during 3 days. Intestinal length was measured and lactase and sucrase activities were determined. The phenotype of intraepithelial and lamina propria lymphocytes was assessed by FACS analysis using markers for $\mathrm{CD} 3, \mathrm{TCR} \alpha \beta, \mathrm{TCR} \gamma \delta, \mathrm{CD} 4, \mathrm{CD} 8 \alpha, \mathrm{CD} 8 \beta, \mathrm{CD} 5, \mathrm{CD} 18, \mathrm{CD} 54$ and CD49d. Similar to what occurs during natural development, spermine treatment of neonatal mice increased intestinal length, decreased lactase and increased sucrase activities. The percentage of intraepithelial lymphocytes expressing TCR $\alpha B, C D 4$, CD5 and CD54 as well as the levels of expression of these antigens increased after spermine treatment on day 12 , similarly to natural maturation. The increase in expression of CD3, TCR $\gamma \delta, C D 18$ and $\mathrm{CD} 49 \mathrm{~d}$ did not reach statistical significance. No effect was observed on CD8 expression. The phenotype of lamina propria lymphocytes was not affected. Spermine administration to 7 and 27 days old mice had no effect on the phenotype of either intraepithelial or lamina propria lymphocytes. Oral spermine administration to neonatal mice induced, in parallel with biochemical maturation, precocious maturation of the murine intestinal immune system and particularly affected differentiation of the intraepithelial lymphocyte population.

\section{INTRODUCTION}

At weaning, the gastrointestinal tract has to adapt to a change from milk to solid food. The mucosal brushborder enzyme activity adapts to the weaning diet: lactase specific activity, which is essential for the digestion of milk lactose, decreases in contrast to maltase and sucrase activities, which increase. The latter enzymes are essential for the digestion of pelleted food carbohydrates (1-4). In parallel to digestive adaptation, immunological adaptation to the new microbial and nutritional antigenic contents of the gut occurs $(5,6)$.

The intestinal immune system is underdeveloped at birth (5). In man, intraepithelial lymphocyte (IEL) expansion starts during intrauterine development and continues after birth (7), in contrast to rodents, in which the intestine contains almost no IEL and only small numbers of lamina propria lymphocytes (LPL) at birth $(8,9)$. In rodents, maturation of the intestine takes place at weaning, when the diet changes from milk to weaning food; in parallel with the known increase in cell numbers, changes occur in the phenotypic characteristics of both IEL and LPL $(8,9)$. As an example of phenotypical maturation of mucosal lymphocytes, the number of lymphocytes 
expressing $\mathrm{CD} 3, \mathrm{~T}$-cell receptor (TCR) $\alpha 3$ and $\mathrm{TCR} \gamma \delta \delta$ membrane antigens increase and the intensity of expression of these membrane antigens increase from low to high intensity (8).

Although intestinal maturation in neonatal rats has been the subject of intensive study, the factors triggering the major biochemical and morphological changes during maturation are still poorly understood $(10,11)$. Exogenous administration of cortisone $(12,13)$, thyroxine $(14)$, insulin $(15)$, and epidermal growth factor (EGF) (16) have been shown to induce precocious biochemical and morphological maturation of the intestine to various degrees. Interestingly, both insulin (17) and EGF $(18,19)$ increase ornithine decarboxylase (ODC) activity in the gut, leading to increased polyamine synthesis (20). Difluoromethylornithine (DFMO), an irreversible inhibitor of ODC activity, prevents the normal increase of polyamine concentration in the intestinal mucosa at weaning and inhibits maturation characteristics such as the increase in brushborder maltase activity, suggesting a relation between polyamines and maturation (10). In addition, delayed postnatal intestinal maturation was observed in the relatively ODC deficient sparse-fur mouse (21). Furthermore, oral administration of polyamines (spermidine, spermine) was shown to induce precocious structural and biochemical maturation of the intestine in neonatal rats $(3-4,22-23)$. Polyamines are ubiquitous low-molecular-weight polycationic compounds that are involved in both cell proliferation and differentiation in many tissues (24).

Based on the observations that biochemical and morphological maturation of enterocytes and maturation of the epithelial intestinal immune system occurs simultaneously, we hypothesized that biochemical and morphological maturation of the intestinal epithelium and development of the epithelial mucosal immune system are driven by the same stimuli. Therefore, we investigated the effect of oral spermine administration on the phenotypic development of the IEL and LPL in the intestine of neonatal mice.

\section{MATERIALS AND METHODS}

\section{Reagents and Antibodies}

Spermine, EDTA, dithiothreitol (DTT), collagenase (Type IV) and bovine serum albumin (BSA) were obtained from Sigma (St. Louis, MO). Medium consisted of RPMI 1640 (Gibco BRL, Paisley, U.K.) supplemented with 10\% heat-inactivated fetal calf serum (Hyclone, Logan, UT), $100 \mathrm{U} / \mathrm{ml}$ penicillin, $100 \mu \mathrm{g} / \mathrm{ml}$ streptomycin, 200 $\mathrm{mM}$ glutamine (Gibco BRL) and $0.1 \mathrm{mg} / \mathrm{ml}$ DNAse (Sigma). Percoll was obtained from Pharmacia (Uppsala, Sweden), biotin-X-NHS was obtained from Calbiochem (La Jolla, CA) and streptavidin phycoerythrin (RPE) from Caltag (SO San Francisco, $\mathrm{CA})$. 
Antibodies were obtained from hybridoma lines GK1.5 (rat anti-mouse CD4, IgG2b) (25), 53-6.72 (rat anti-mouse CD8 $\alpha$, IgG2a) (26), YN1/1.74 (rat anti-mouse CD54, ICAM, IgG2a) (27), R1-2 (rat anti-mouse CD49d, a4 integrin, IgG2b) (28), 2E6 (hamster anti-mouse CD18, IgG) (29), H57-597 (hamster anti-mouse TcR $\beta$, IgG) (30) all from the ATCC (Rockville, MD). Hybridoma cell line 145-2Cll (hamster antimouse CD3, IgG) (31) was a gift of Dr. Bluestone (National Cancer Institute, Bethesda, MD). Hybridoma GL3 (hamster anti-mouse TcR8, IgG) (32) was kindly provided by Dr. L. Lefrancois (UNCONN Health Center, Farmington, CT). Antimouse CD8B (Yb 156.7.7, IgG2b) (33) and CD5 (YTS 121.5.2, IgG2b) (34) antibodies were a gift of Dr. S.P. Cobbold (Sir William Dunn School of Pathology, Oxford, UK). The control antibody GL113 (rat IgG) was a gift of Dr. Savelkool (Erasmus university, Rotterdam, the Netherlands). Monoclonal antibodies (mAbs) were purified from culture supernatant by affinity chromatography. All antibodies were conjugated with biotin.

\section{Animals}

Swiss mice were obtained from Charles River Breeding Laboratories (Heidelberg, FRG). They were maintained on a standard laboratory diet and were allowed free access to water. Guidelines of the Committee for Care and Use of Laboratory Animals from the Maastricht University were followed throughout. Litters were reduced to 10 pups per lactating mother, with free access to the nipples.

\section{Experimental design}

Spermine $(0.25 \mu$ moles/gram body weight in $50 \mu \mathrm{l}$ saline $)$ was given by gastric intubation. Spermine was given during 3 days, twice daily at 7.00 a.m. and 7.00 p.m. After spermine administration, the mice were immediately returned to their mother. The spermine dose was calculated on the basis of data of Dufour et al. (3), who showed that the maturational effect of spermine was dose dependent. Pilot experiments in mice indicated that the spermine dose chosen increased the intestinal sucrase activity and decreased the lactase activity in neonatal mice. Three experimental groups were made, each consisting of a subgroup treated with spermine and a subgroup treated with saline (control). Within one litter, half of the neonatal mice was given spermine and the other half saline.

Group 1: Either spermine $(n=18)$ or saline $(n=18)$ was given on days 7,8 and 9 . The mice were sacrificed on day 10 .

Group 2: Either spermine $(n=24)$ or saline $(n=24)$ was given on days 12,13 and 14. The mice were sacrificed on day 15 .

Group 3: Either spermine $(n=6)$ or saline $(n=6)$ was given on days 27,28 and 29 . The animals were sacrificed on day 30 . This group was used as a control for the effect of spermine administration after natural maturation. 


\section{Biochemical determinations}

Approximately $1 \mathrm{~cm}$ of small intestine was removed, flushed with $\mathrm{PBS}$, dried with paper, sealed in parafilm and kept at $-20^{\circ} \mathrm{C}$ until analysis of protein content and specific activity of lactase and sucrase. These analyses were performed at the Laboratory of General Biochemistry and Physiology, University of Liège, Belgium, according to Bradford and Dahlqvist (35). The enzyme activities were expressed as micromoles of substrate hydrolysed per minute per gram of intestinal proteins.

\section{Intestinall length measurements}

After sacrificing the animals, the entire small bowel from the stomach to the appendix was immediately removed. The intestine was flushed with PBS $\left(4^{\circ} \mathrm{C}\right)$ to remove the faecal contents and subsequently layered on wetted parafilm for length measurement.

\section{Isolation of intestinal lymphocytes}

IEL and LPL were isolated as described previously (8). Pilot experiments were performed to optimize the incubation time of each step of the isolation procedure for each Group. After IEL isolation we checked if the basement membrane was still intact. During the experiments it was randomly checked if the basement membrane was still intact after IEL isolation.

In short, the small intestine used for length measurements was trimmed of fat, mesentery and Peyer's patches. Subsequently, the intestine was cut longitudinally, washed twice with PBS supplemented with $50 \mathrm{mM}$ glucose, and cut in segments of $0.5-1.0 \mathrm{~cm}$. IEL were isolated by incubation of the segments of intestine in an EDTA/DTT solution for 7 (Group 1), 10 (Group 2) or 15 min (Group 3), after which the supernatant was removed and the segments were incubated in medium for 20,25 or $30 \mathrm{~min}$ at $37^{\circ} \mathrm{C}$, for Group 1,2 and 3 respectively. Next, the cell suspensions obtained were passed over a $50 \mu \mathrm{m}$ nylon gauze, centrifuged $(5 \mathrm{~min}, 370 \mathrm{~g}$ ) and resuspended in medium. LPL were isolated from the remaining intestine on the nylon gauze, by incubation in $20 \mathrm{ml}$ medium supplemented with 7,000 Units collagenase in a shaking waterbath at $37^{\circ} \mathrm{C}$ for 20 (Group 1), 25 (Group 2) or 30 min (Group 3). This procedure was repeated once after the supernatant with the freed cells was removed. Next, the cell suspensions obtained were passed over a $50 \mu \mathrm{m}$ gauze, pelleted and resuspended in medium. A further purification of the lymphocytes (both IEL and LPL) was obtained by density gradient centrifugation of the obtained epithelial and lamina propria cell fractions, using a discontinuous percoll gradient. The viability was always over $90 \%$ as assessed by trypan blue exclusion. Cells were kept at $4^{\circ} \mathrm{C}$ until further processing. 


\section{FACS analysis}

To obtain sufficient numbers of lymphocytes of young animals ( $<20$ days) for FACS analysis, intestines of 3 mice were pooled. Cells $\left(10^{5}\right.$ in $0.1 \mathrm{ml}$ ) were washed with PBS containing $0.1 \% \mathrm{BSA}$ and azide and incubated with mAbs at the appropriate dilutions $(1-10 \mu \mathrm{g} / \mathrm{ml})$ in PBS containing $0.1 \% \mathrm{BSA}$ and azide for $1 \mathrm{hr}$ at $4^{\circ} \mathrm{C}$. Subsequently, the cells were washed 3 times with cold PBS containing $0.1 \% \mathrm{BSA}$ and azide $\left(4^{\circ} \mathrm{C}\right)$ and incubated with streptavidin-phycoerythrin for $1 \mathrm{hr}\left(4^{\circ} \mathrm{C}\right)$. After this incubation, the cells were washed 3 times and analyzed using a FACSsort equipped with the LYSES II program (Becton and Dickinson, Sunnyvale, CA). Cells were gated out using forward versus side scatter to exclude aggregates, dead cells or debris. Fluorescence intensity was expressed as mean channel number. As check of purity of the IEL and LPL population the percentage of $\mathrm{CD} 4^{+}$cells in the IEL fraction $(<30 \%)$ and the percentage TCR $\gamma \delta^{+}$cells in the LPL fraction $(<20 \%)$ was evaluated before analysis.

\section{Statistical analysis}

The results were expressed as the mean \pm SEM or as individual dots, with a line indicating the mean. The Mann-Whitney U-test was used to determine the statistical significance between saline and spermine-treated mice, $p<0.05$ was considered statistically significant.

\section{RESULTS}

\section{Effects of spermine on biochemical maturation}

First, the effect of spermine administration on the brushborder enzyme activity was investigated. Lactase specific activity decreased during maturation in saline-treated animals and spermine administration from day 7 to 10 (Group 1) and day 12 to 15 (Group 2) significantly enhanced this decrease (Figure 1). Simultaneously, sucrase specific activity increased with maturation. Spermine administration to neonatal mice (Group 1 and 2) induced a precocious increase in sucrase activity; adult levels of sucrase activity, i.e. levels present on day 30, were reached in Group $2(p<0.003)$ (Figure 1). In Group 1, sucrase activity increased 2.5 fold, however, statistical significance was not reached. No effects on the brushborder enzyme activity were observed in mature mice receiving spermine from day 27 to 30 (Group 3). 
Table 1. Oral spermine administration leads to increased intestinal length in meonatal mice:

\begin{tabular}{llllll}
\multicolumn{1}{c}{ Group 1 } & \multicolumn{2}{c}{ Group 2 } & \multicolumn{2}{c}{ Group 3 } \\
\hline $\begin{array}{l}\text { saline } \\
(\mathrm{n}=18)\end{array}$ & $\begin{array}{l}\text { spermine } \\
(\mathrm{n}=18)\end{array}$ & $\begin{array}{l}\text { saline } \\
(\mathrm{n}=24)\end{array}$ & $\begin{array}{l}\text { spermine } \\
(\mathrm{n}=24)\end{array}$ & $\begin{array}{l}\text { saline } \\
(\mathrm{n}=6)\end{array}$ & $\begin{array}{l}\text { spermine } \\
(\mathrm{n}=6)\end{array}$ \\
\hline $18.9 \pm 1.9$ & $21.0 \pm 2.6^{\sharp}$ & $24.3 \pm 2.2$ & $25.7 \pm 2.3^{\sharp}$ & $40.1 \pm 3.9$ & $42.8 \pm 4.5$ \\
\hline
\end{tabular}

- Data are given in $\mathrm{cm}$ as the mean $\pm \mathrm{SD}$.

$" \mathrm{p}<0.02$ for spermine-treated in comparison with saline-treated mice.

Moreover, a significant increase in intestinal length after spermine-treatment was observed in mice of Group 1 and 2 but no effect on the intestinal length was observed in spermine-treated mature mice of Group 3 (Table 1). To confirm the increase in intestinal length in Group 1, dry weight of the intestines of 3 control animals with an average intestinal length of $16.1 \pm 0.6 \mathrm{~cm}$ and 3 spermine-treated mice with an average intestinal length of $18.3 \pm 0.6 \mathrm{~cm}$ was determined. A representative increase in dry weight from $0.044 \pm 0.003$ gram in control mice to $0.054 \pm 0.005$ gram in spermine-treated mice was observed.

Figure 1. Oral spermine administration decreased lactase specific activity (A) and enhances sucrase specific activity (B) in neonatal mice. The enzyme activity is expressed as micromoles of substrate hydrolysed per minute per gram of intestinal protein. Data are given as the mean \pm SEM of 6 animals. Open bars represent the saline-treated animals and the hatched bars represent the spermine-treated animals.
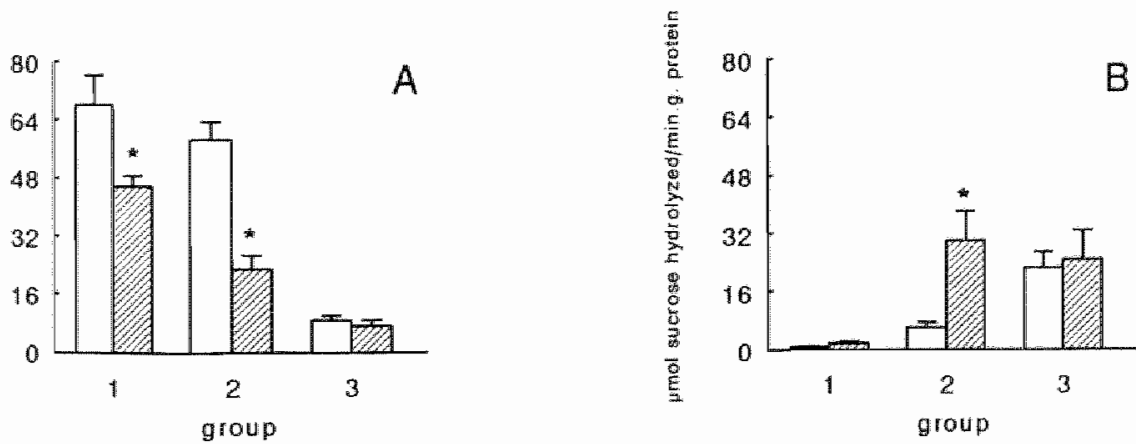


\section{Effect of spermine on phenotypic characteristics of IEL}

Natural maturation of the intestinal immune system is characterized by an increase in the number of IEL and LPL, and an increase in membrane antigen expression $(6,8,9)$. The effect of oral spermine administration on the mucosal immune system was investigated by assessing the phenotype of IEL and LPL, using FACS analysis.

Group 1. Spermine administration did effect neither the number of IEL nor the phenotype of IEL (data not shown).

Group 2. Spermine did not significantly affect the number of IEL, however, it induced a more mature IEL phenotype in comparison with saline-treated mice (Figures 2 and 3). CD3 IEL expression increased from 36 to $42 \%$. In parallel, an increase in expression of both TCR $\alpha \beta$ and TCR $\gamma \delta$ was detected. The increase in TCR $\gamma \delta^{+}$IEL was found in most experiments, but did not reach statistical significance, whereas the percentage TCR $\alpha \beta^{+}$IEL increased significantly from 8 to $21 \%(p<0.02)$. In addition, the percentage of $\mathrm{CD}^{+}$IEL $(22 \%)$ observed after spermine treatment was similar to the percentage found in 30 day old mice indicating an increase of $10 \%(\mathrm{p}<0.04)$ to adult levels. No effect was found on CD8 $\alpha$ and CD8ß (data not shown) expression. Moreover, a significant increase in CD5 expression from 3 to $10 \%$ was observed $(\mathrm{p}<$ 0.05 ) (Figure 2). These data clearly indicate that, although spermine does not lead to a precocious increase in cell numbers, it induces precocious differentiation of IEL, particularly $\mathrm{CD} 4^{+}, \mathrm{TCR} \alpha \beta^{+}$and $\mathrm{CD} 5^{+}$IEL.

Normal development of the mucosal immune system is characterized by both an increase in the percentage of IEL expressing a defined membrane antigen as well as an increase in the intensity of membrane antigen expression (8). Spermine administration from day 12 to 15 , induced an increase in both the percentage of cells expressing these membrane antigens and the intensity of antigen expression, a pattern that is similar to normal development (Figure 3). For both $\mathrm{CD} 4$ and CD5 the peak representing CD4 or $\mathrm{CD}^{+}$IEL was higher and shifted to the right in comparison with the peak of control animals, indicating an increase in both the number and the intensity of expression of these membrane antigens (Figure 3). The effect of spermine on TCR $\alpha \beta$ expression was characterized by an increase in the number of cells expressing TCR $\alpha \beta$ rather than an increase in the intensity of TCR $\alpha \beta$ expression, as appeared from the higher peak representing the TCR $\alpha \beta$ positive cells in comparison to the lower peak in control animals (Figure 3). 
Figure 2. Oral spermine administration induces precocious expression of certain IEL membrane antigens in neonatal mice. Data are given as individual dots with a line indicaing the mean. Open dots represent the saline-treated anmals and the black dots represent the spermine-treated animals. Group 2, illustrated by 1 and 2, consisted of two subgroups of 7 mice each and Group 3, whstrated by 3 and 4, consisted of wo subgroups of 6 mice each.
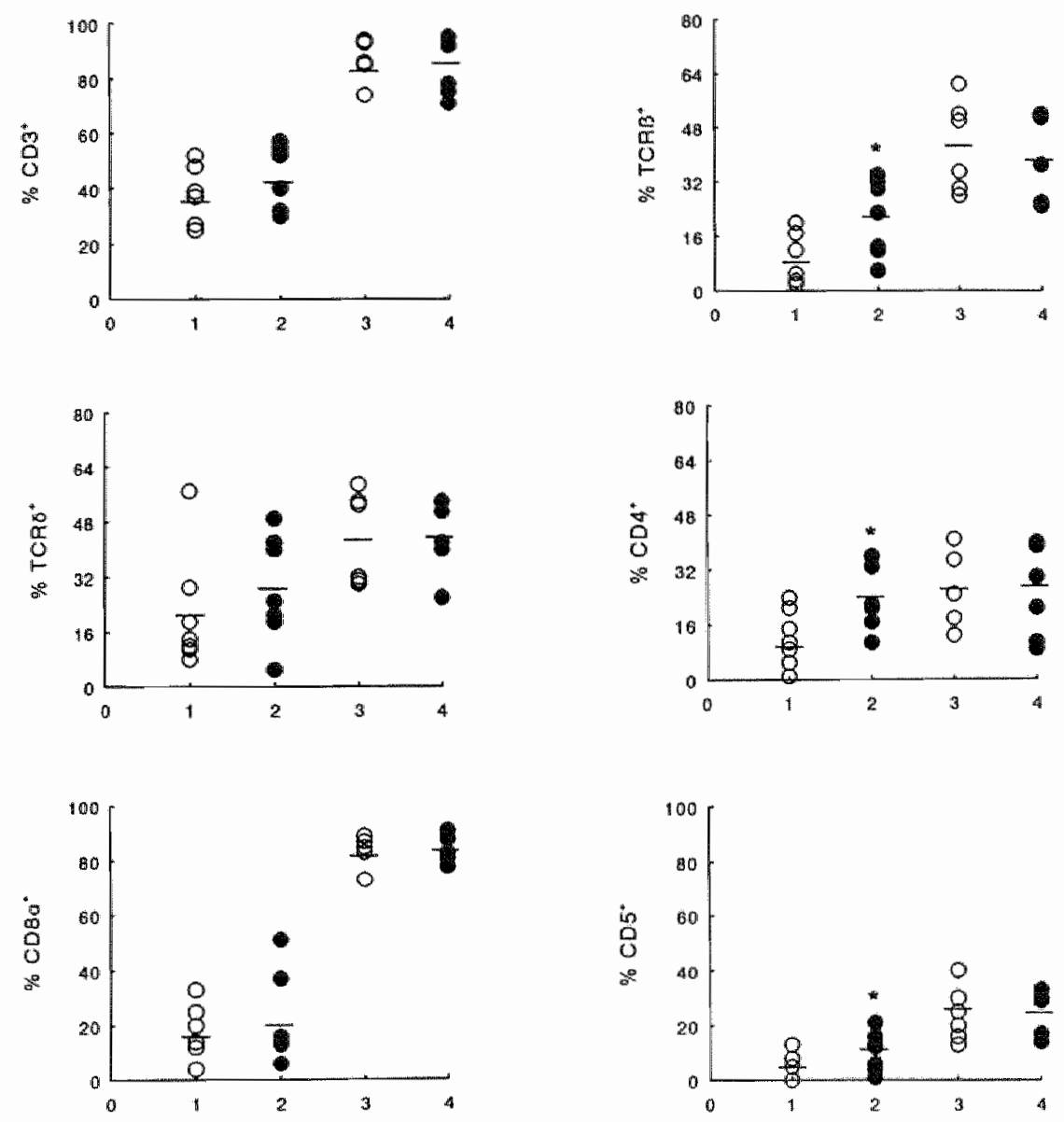

Furthermore, the adhesion molecule expression of IEL was also affected by oral spermine administration from day 12 to 15 . An increase from $22 \%$ in control animals to $36 \%$ in spermine-treated animals, corresponding with percentages found in 30 old mice, was observed for CD18 expression. Further, a significant increase, to adult levels, in the percentage of CD54. IEL from 18 to $29 \%(\mathrm{p}<0.05)$ was observed. Further, a consistent but not significant increase of CD49d expression was detected (Figure 4A). 
Group 3. Similar to Group 1, spermine administration did not affect membrane antigen expression, except for a slight non-significant decrease in expression of the adhesion molecules CD18, CD54 and CD49d (Figure 4A).

Figure 3. Oral spermine administration from day 12 to 15 changed CD4, CD5, and TCR ag expression by IEL. The X-axis gives the relative fluorescence intensity and the $Y$-axis the number of cells. The data of $I$ representative experiment out of 7 experiments are depicted.
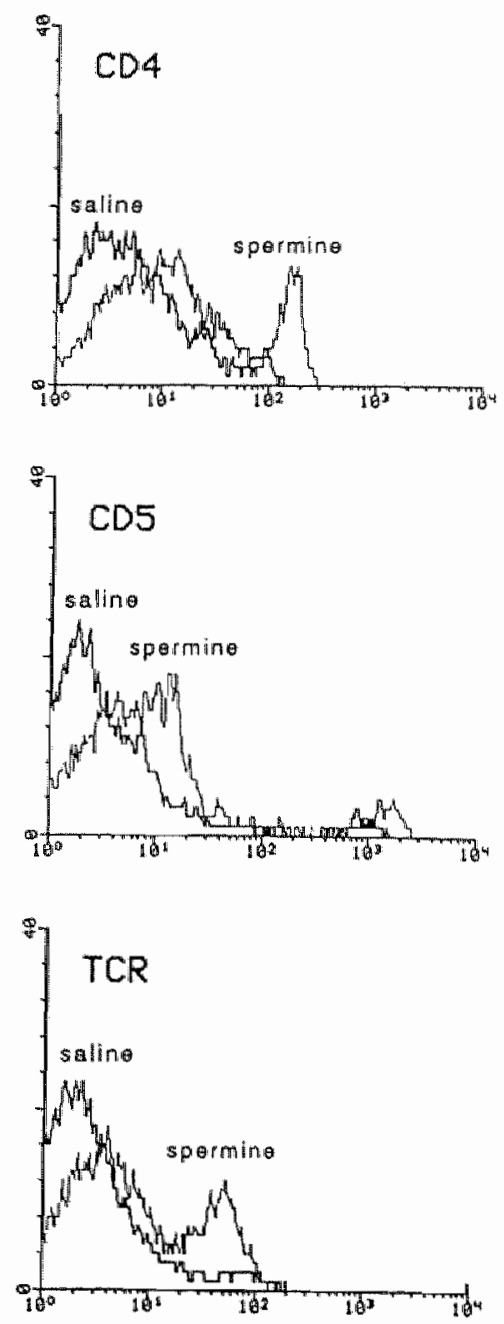
Figure 4. Orat spermine administration affects the expression of certain adhesion molecule by IEL (A) and LPL (B). Data are given as individual dots with a line indicating the mean. Open dots represent the saline-treated animals and the black dots represent the spermineireated animals. Group 2, illustrated by 1 and 2, consisted of two subgroups of 7 mice each and Grotu 3. Wlustrated by 3 and 4 , consisted of wo subgroups of 6 mice each. ${ }^{*} p<0,05$ by Mann-Whiney test)
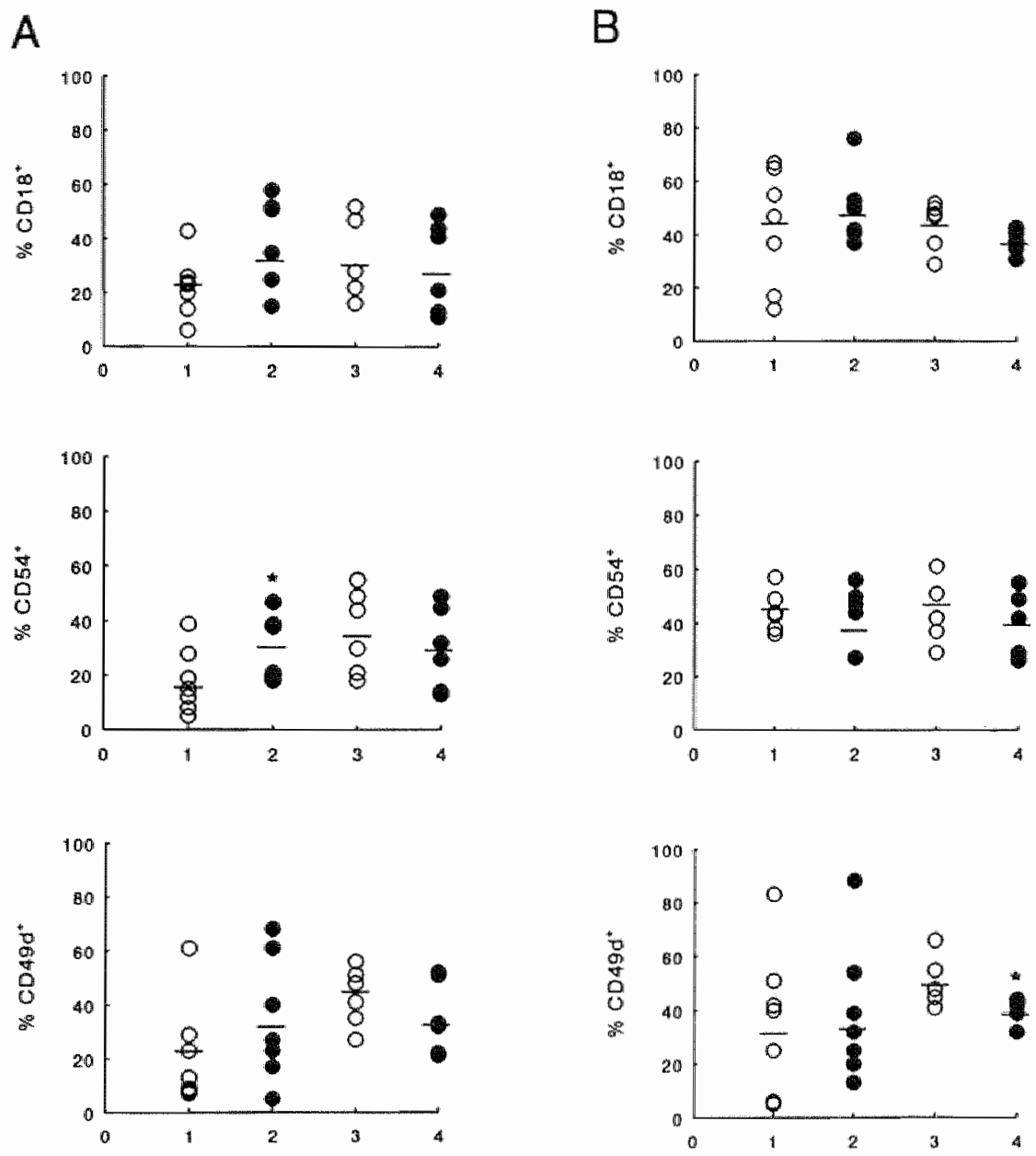

Effect of spermine on phenotype characteristics of LPL

Natural maturation of LPL was characterized by an increase in the number of LPL just before weaning and by an increase in the expression of membrane antigens like CD3, TCR $\alpha B, C D 4, C D 8, C D 5$ (data not shown), CD18, CD54 and CD49d (Figure 4B), and a decrease of the relative percentage "TCR $y \delta$. However, spermine treatment neither induced an increase in the number of LPL, nor phenotypically affected LPL in 
all Groups studied. In line with these results, no effect of spermine was found on the intensity of membrane antigen expression on LPL.

\section{DISCUSSION}

Our data show that oral administration of spermine in the mouse induces biochemical maturation of the small intestine, similarly to what has been reported for the rat (3-4, 22-23). Maturation was reflected by a decrease in lactase specific activity and an increase in sucrase specific activity. The increase in sucrase activity in neonatal mice, treated with spermine from day 12 to 15 , led to levels that equalled those in adult mice. Neonatal mice, treated from day 7 to 10 , also responded to oral spermine administration but only with a decrease in lactase activity, the effect was, however, less pronounced in comparison with Group 2. Furthermore, we observed a trophic effect of spermine on the small intestine both at 10 and 15 days, as determined by the increase in intestinal length. This effect has been previously reported for the rat (4).

Although spermine induced proliferation of crypt cells in the rat (36), it did not affect the number of IEL or LPL in our study. This indicates that spermine affected neither the proliferation of IEL or LPL, nor the migration of lymphocytes into the intestine. A clear phenotypic maturation of IEL, however, was induced by oral spermine administration from day 12 to 15 . The IEL expression of TCR $\alpha \beta, C D 4$, CD5, as well as CD54 in these mice resembled that of IEL in untreated mice of 25 to 30 days of age (8). In addition, similar to natural maturation, also an increase in the expression of CD3, TCR $\gamma \delta, C D 18$ and $\mathrm{CD} 49 \mathrm{~d}$ was observed, but statistical significance was not reached compared with saline-treated mice. No effect was detected on CD8 expression. Furthermore, natural maturation is characterized by a relative decrease in TCR $\gamma \delta^{+}$IEL compared with TCR $\alpha \beta^{+}$IEL (8). In Group 2, spermine administration induced a similar response. Taken together, these data show that oral spermine administration has a positive effect on the differentiation and developmental characteristics of IEL in neonatal mice. In contrast to the effect of oral spermine administration on lactase activity and intestinal length, the effect on the epithelial mucosal immune system appears to be related to the postnatal age of the mice.

Oral spermine administration from day 12 to 15 affected IEL differentiation but not LPL differentiation, which may indicate that the epithelium plays an important role in this maturation effect of spermine on IEL. This hypothesis is supported by our data showing no effect of spermine administration on IEL differentiation in mice of Group 1 (10 dlays). Spermine administration at this age did only significantly affect lactase activity and not sucrase activity. Further, the effect was less pronounced than that in Group 2 ( 15 days), indicating that a certain degree of maturation of the intestinal epithelium is required for IEL differentiation. It is of interest to note that $T$ cell 
lymphopoiesis occurs in thymic and intestinal epithelium, tissues that share the same endodermic origin (37).

Data indicating that polyamines play an important role in $T$ cell differentiation and particularly $T$-cell maturation were reported by Thomas et al. (38), using the MLR lpr/pr mouse model. The endogenous polyamine concentration in the thymus of these mice was found to be elevated. Reduction of the endogenous polyamine concentration by administration of DFMO prevented the characteristic accumulation of "immature" CD4 ${ }^{\circ} 8^{-}$(double negative) peripheral $\mathrm{T}$ cells in these mice.

In 30 day old mature mice, spermine treatment did neither affect the brushborder: enzymes nor membrane antigen expression of both IEL and LPL. However, the percentage of CD $49 \mathrm{~d}^{+}$LPL on day 30 was significantly decreased after spermine treatment. These data suggest that spermine administration to mature mice leads to activation of LPL and subsequent downregulation of CD $49 \mathrm{~d}$ expression, an adhesion molecule expressed by most unstimulated lymphocytes (28).

Mouse IEL mainly consist of two subpopulations of lymphocytes: thymusdependent and thymus-independent IEL. These IEL populations are phenotypically different (39-41) and develop via different pathways. Our results show that spermine affects mainly the thymus-dependent (TCR $\alpha \beta^{+}, \mathrm{CD} 4^{+}, \mathrm{CD} 5^{+}$) IEL population, and to lesser extent the thymus-independent (CD $8 \alpha \alpha^{+}$, TCR $\left.\gamma \delta^{+}\right)$IEL population. This might demonstrate that various $T$ cell subsets are differently affected by enhanced spermine concentrations, or by the effects of oral spermine administration. There are indications that polyamine biosynthesis and the expression of ODC protein is differentially regulated within subpopulations of thymic T cells (42). Moreover, Thomas et al. (43) demonstrated that high polyamine concentrations specifically affected the CD4 population.

Furthermore, the development of the mucosal immune system is regulated by internal as well as external triggers $(11,44-45)$. In particular, the complete development of thymus-dependent IEL (TCR $\alpha 3^{+}, \mathrm{CD}^{*}, \mathrm{CD} 5^{+}$) was shown to be dependent on external triggers, such as microbial and nutritional antigens $(8,46)$. Similarly, biochemical intestinal maturation (lactase, sucrase and maltase activity) is also dependent on internal as well as external triggers. The decrease in lactase activity in the third week after birth seems to be dependent on the external trigger of the luminal contents, in contrast to sucrase and maltase activity, which seem to be dependent on hormones of the adrenal gland $(11,47-48)$. Oral spermine administration affects both lactase and sucrase activity, showing that oral spermine administration acts on the intestine through different ways.

It is thus far unresolved whether endogenous polyamines trigger the normal maturation and differentiation of the intestine, and whether exogenous polyamines are also involved in these processes. We and others have shown that exogenous spermine induces precocious biochemical, morphological, and immunological maturation of the intestine $(3-4,13,23,36,49-50)$. The major source of exogenous polyamines, for mice, are food pellets (50). Just before weaning, the rodents start to eat food pellets 
containing a high concentration of exogenous polyamines, which might trigger intestinal maturation $(22,51)$. Furthermore, polyamine concentrations in rat and human milk increase during lactation (52-53).

The mechanisms by which oral administration of spermine affects the mucosal epithelium and the mucosal immune system have yet to be elucidated. There is some evidence that spermine acts indirectly through hormones of the pituitary-adrenal axis. First, adrenalectomy has been shown to reduce changes in specific activities of disaccharidases induced by spermine (49), and second, spermine enhances the secretion of ACTH and corticosterone, probably via released gastro-intestinal homones (50). However, only part of the effects of spermine on the intestine are regulated via the pituitary-adrenal axis, since adrenalectomy did not affect the spermine-induced decrease in lactase activity (48). These data confirm that sucrase and lactase activity are regulated via different mechanisms. It remains to be revealed whether the effect of spermine on IEL differentiation occurs via hormones of the pituitary-adrenal axis, or via maturation of the intestinal epithelium. A direct effect of spermine on IEL differentiation should, however, not be excluded.

In summary, the data presented indicate that spermine plays a role in the maturation of murine intestinal epithelium and differentiation of IEL, particularly TCR $\alpha B^{+}, \mathrm{CD}_{4}$, and $\mathrm{CD} 5^{+}$IEL. The functional aspects of the influence of spermine on IEI differentiation are subject of further studies.

\section{Acknowledgements}

The authors thank Prof. G. Dandrifosse of the Laboratory of General Biochemistry and Physiology, University of Liege, Belgium, for determination of the protein content, the lactase and sucrase activity of the spermine-treated and control mice.

This work was supported by a Grant from Nutricia Research, Zoetermeer, the Netherlands.

\section{REFERENCES}

1. Arthur $\mathrm{AB}$. Development of disaccharidase activity in the small intestine of suckling mouse. $N Z$ Med J 67: 614-616, 1968.

2. Hennings $\mathrm{SJ}$, Kretchmer N. Development of intestinal function in mammals. Enzyme 15: 3-23, 1973.

3. Dufour C, Dandrifosse G, Forget P, Vermesse F, Romain N, Lepoint P. Spermine and spermidine induce intestinal maturation in the rat. Gastroenterology 95: 112-116, 1988.

4. Georges P. Dandrifosse G, Vermesse F, Forget $P$, Deloyer $P$, Romain N. Reversibility of spermine-induced intestinal maturation in the rat. Dig Dis Sci 35: 1528-1536, 1990.

5. Strobel S. Immunologically mediated damage to the intestinal mucosa. Acta Paediatr Scand Suppl 365: $46-57,1990$.

6. Lyscom N, Brueton MJ. The development of intraepithelial and Peyer's patch lymphocyte subtypes in the small intestine of newborn rats. Clin Exp Immunol 54: 158-162, 1983. 
7. Machado CSM, Rodrigues MAM, Maffei HVL. Assessment of gut intraepithelial lymphocytes during late gestation and the neonatal period. Biol Neonate 66: 324-329, 1994.

8. ter Steege JCA, Buurman WA, Forget PP. The neonatal development of intraepithelial and lamina propria lymphocytes in the murine intestine. Dev Irmmunol 5: 121-128, 1997.

9. de Geus $\mathbb{B}$, Rozing $J$. Co-expression of TCR- $B$ and TCR- $\delta$ chains on intestinal lanina propria lymphocytes during neonatal development in euthymic and athymic mice. In thesis. Differentiation and characterization of murine intestinal epithelial lymphocytes. Pasmans BV", "sGravenhage, pp. 90-109, 1992.

10. Luk GD, Marton LJ, Baylin SB. Ornithine decarboxylase is important in intestinal mucosal maturation and recovery from injury in rats. Science 210: 195-8, 1980.

11. Diamond JM. Hard-wired local triggering of intestinal enzyme expression. Nature 324:408, 1986.

12. Doell $R G$, Kretchmer N. Intestinal invertase: Precocious development of activity after injection of hydrocortisone. Science 143: 42-44, 1963.

13. Capano G, Bloch KJ, Schriffrin EJ, Dascoli JA, Israel EJ, Harmatz PR. Influence of the polyamine, spermidine, on intestinal maturation and dietary antigen uptake in the neonatal rat. $J$ Pediatr Gastroenterol Nutr 19: 34-42, 1994.

14. Moog F, Yeh K. Pinocytosis persists in the ileum of hypophysectomized rats unless closure is induced by thyroxine or cortisone. Dev Biol 69: 159-169, 1979.

15. Menard D, Malo $C$, Calvert $R$. Insulin accelerates the development of intestinal brush border hydrolytic activities of suckling mice. Dev Biol 85: 150-5, 1981.

16. Malo C, Ménard D. Influence of epidermal growth factor on the development of suckling mouse intestinal mucosa. Gastroenterology 83: 28-35, 1982.

17. Feldman EJ, Aures D, Grossman MI. Epidermal growth factor stimulates ornithine decarboxylase activity in the digestive tract of mouse. Proc Soc Exp Biol Med 159: 400-400, 1978.

18. Maudsley DV, Leif J, Kobayashi Y. Omithine decarboxylase in rat small intestine. Stimulation with food or insulin. Am I Physiol 231: 1557-1561, 1976.

19. Seidel ER. Hormonal regulation of postprandial induction of gastrointestinal omithine decarboxylase activity. Am J Physiol 251: G460-G466, 1986.

20. Fitzpatrick LR, Wang P, Johnson LR. Effect of epidermal growth factor on polyaminesynthesizing enzymes in rat enterocytes. Am J Physiol 252: G209-G214, 1987.

21. Malo C, Qureshi IA, Letarte J. Postuatal maturation of enterocytes in sparse-fur mutant mice. $A m$ JPhysiol 250: G177-G184, 1986.

22. Buts. JP, De Keyser N, Kolanowski $J$, Sokal E, Van Hoof F. Maturation of willus and erypt cell functions in rat small intestine. Role of dietary polyamines. Dig Dis Sci 38: 1091-1098, 1993.

23. Wild GE, Daly AS, Sauriol N, Bennett G. Effect of exogenously administered polyamine on the structural maturation and enzyme ontogeny of the postnatal rat intestine. Biol Neonate 63." 246$257,1993$.

24. Janne J, Poso H, Raina A. Polyamines in rapid growth and cancer. Biochim Biophys Acta 1473: $241-293,1978$.

25. Dialynas DP, Wilde DB, Marrack P, Pierres A, Wall KA, Harvan W, Otten G, Loken MR, Pierres M, Kappler J, Fitch FW. Characterization of the murine antigenic determinant, designated L3T4a, recognized by monoclonal antibody GK1.5: Expression of L3T4a by functional T cell clones appears to correlate primarily with class II MHC antigen reactivity. Immunol Rev 74:29-56, 1983.

26. Ledbetter JA, Herzenberg LA. Xenogeneic monoclonal antibodies to mouse lymphoid differentiation antigens. Immunol Rev 47: 63-90, 1979.

27. Takei $\mathrm{F}$. Inhibition of mixed lymphocyte response by a rat monoclonal antibody to a novel murine lymphocyte activation antigen (Mala-2). J Immunol 134: 1403-1407, 1985.

28. Holzmann B, Mclntyre BW, Weissman IL. Identification of a murine Peyer's Patch-specific lymphocyte homing receptor as an integrin molecule with an $\alpha$ chain homologous to human VLA4a. Cell 56: $37-46,1989$. 
29. Metlay JP, Witmer-Pack MD, Agger R, Crowley MT, Lawless D, Steinman RM. The distinct leukocyte integrins of mouse spleen dendritic cells as identified with new hamster monoclonal antibodies. J Exp Med 171: 1753-1771, 1990.

30. Kubo RT, Born W, Kappler JW, Marrack P, Pigeon M. Characterization of a monoclonal antibody which detects all murine ogf T cell receptors. J Inmwnol 142: 2736-2742, 1989.

31. Oberdan L. Foo M, Sachs DH, Samelson LE, Bluestone JA. Identification of a monoclonal antibody specific for a murine T3 polypeptide. Proc Natl Acad Sci. USA 84: 1374-1378, 1987.

32. Goodman T, Lefrancois L. Intraepithelial lymphocytes. Anatomical site, not $T$ cell receptor form, dictates phenotype and function. $J$ Exp Med 170:1569-1581, 1989.

33. Qin $S$, Cobbold $S$, Benjamin $R$, Waldmann $H$. Induction of classical transplantation tolerance in the adult. J Exp Med 169: 779-794, 1989.

34. Cobbold S??, Jayasuriya A, Nash A, Prospero TD, Waldmann H. Therapy with monoclonal antibodies by elimination of T-cell subsets in vivo. Nature 312: $548-551,1984$.

35. Dathlquist A. Method for assay of intestinal disaccharidases. Anal Biochem 7: 18-25, 1964.

36. Harada E, Hashimoto $Y$, Syuto B. Orally administered spermine induces precocious intestinal maturation of macromolecular transport and disaccharidase development in suckling rat. Comp Blocherv Physiol 109A: 667-673, 1994.

37. Poussier P, Julius M. Intestinal intraepithelial lymphocytes: The plot thickens. I Exp Med 180: $1185-1189,1994$.

38. Thomas TJ, Gunnia UB, Thomas T. Reversal of the abnormal development of $T$ cell subpopulations in the thymus of autoimmune MLR-lpr/pr mice by a polyamine biosynthesis inhibitor. Autoimmunity 13:275-83, 1992.

39. Guy-Grand D, Cerf-Bensussan N, Malissen B, Malassis-Seris M, Briottet C, Vassalli P. Two gut intraepithelial $C D 8^{*}$ lymphocyte populations with different $T$ cell receptors: $A$ role for the gut epithelium in T cell differentiation. J Exp Med 173: 471-481, 1991.

40. Lefrancios L. Phenotypic complexity of intraepithelial lymphocytes of the small intestine. $J$ Immunol 147: 1746-1751, 1991.

41. Poussier P, Julius M. Thymus independent T cell development and selection in the small intestinal epithelium. Anmu Rev Immunol 12: 52 1-553, 1994.

42. Ehrke MJ, Porter CW, Eppoliti C, Mihich E. Selective modulation by $\alpha$-difluoromethylomithine of T-lymphocyte and antibody mediated cytotoxic responses to mouse tumor allografts. Cancer Res 46:2798 2803, 1986.

43. Thomas TJ, Gunnia UB, Yurkow EJ, Seibold JR, Thomas TJ. Inhibition of calcium signalling in murine splenocytes by polyamines: differential effects on CD4 and CD8 T-cells. J Biochem 291 : $375-381,1993$.

44. Ferguson A, Parrott DM. Growth and development of "antigen-free" grafts of foetal mouse intestine. J Pathol 106: 95-101, 1972.

45. Mosley RL, Klein JR. Peripheral engraftment of fetal intestine into athymic mice sponsors $\mathrm{T}$ cell development: Direct evidence for thymopoietic function of murine small intestine. $J \operatorname{Exp} M e d$ 176: $1365-1373,1992$.

46. Bandeira $A$, Itohara $S$, Bonneville $M$, Burlen-Defranoux $O$, Mota-Santos $T$, Coutinho $A$, Tonegawa S. Extrathymic origin of intestinal intraepithelial lymphocytes bearing T-cell antigen receptor yó. Proc Nal Acad Sci USA 88: 43-47, 1991.

47. Yeh KY, Holt PR. Rat milk maintains intestinal lactase activity in rat pups whereas artificial formulas do not. Pediatr Res 19: 963-967, 1985.

48. Tsuboi KK, Kwong LK, Ford WD, Colby T, Sunshine P. Delayed ontogenic development in the bypassed illewm of the infant rat. Gastroenterology 80: 1550-1556, 1981.

49. Kaouass M, Deloyer P, Dandrifosse G. Intestinal development in suckling rats: direct or indirect spermine action?. Digestion 55: 160-167, 1994. 
50. Kaouass $M$, Sulon J, Deloyer $P$, Dandrifosse G. Spermine-induced precocious intestinal maturation in suckling rats: possible involvement of glucocorticoids. $J$ Endocrinol 141:279-283, 1994.

51. Bardocz S. The role of dietary polyamines. Eur J Clin Nutr 47:683-690, 1993.

52. Romain $N$, Dandrifosse $G$. Jeusette $F$, Forget P. Polyamine concentration in rat milk and food, human milk, and infant formulas. Pediarr Res 32: 58-63, 1992.

53. Buts JP, De Keyser N, De Raedemaeker L, Collette E, Sokal EM. Polyamine profiles in human milk, infant artificial formulas and semi-elemental diets. $J$ Pediarr Gastroenterol Nutr $21: 44-49$, 1995. 
.74 


\section{CHAPTER 4}

NITROTYROSINE IN PLASMA OF COELIAC DISEASE PATIENTS AS DETECTED BY A NEW SANDWICH ELISA

Ter Steege JCA, Koster-Kamphuis L, Van Straaten EA, Forget PPh, Buurman WA. Free Radical Biol Med; In Press 


\section{ABSTRACT}

Inflammation is characterized by increased nitric oxide production. Nitrotyrosine has recently been suggested to be useful as a marker for NO-mediated tissue damage. In context of the development of an ELISA for detection of nitrotyrosine in plasma. monoclonal anti-nitrotyrosine antibodies were developed by injecting mice with nitrated keyhole limpet hemocyanin. The specificity of the antibodies was determined by binding to nitrated BSA, lack of binding to unmodified BSA, tyrosine, 3chlorotyrosine or phenylalanine and inhibition of binding by nitrotyrosine. The antibodies developed are useful for Western blot analysis and immunohistochemical staining. Using these antibodies a nitrotyrosine sandwich ELISA was developed with a lower detection limit of approximately $0.2 \mathrm{nM}$. The intra- and interassay variance were $2.4 \%$ and $11.9 \%$, respectively. Using this newly developed ELISA, $1.27 \pm 1.03$ $\mu \mathrm{M}$ nitrotyrosine was detected in plasma samples of coeliac disease patients whereas nitrotyrosine was undetectable in controll samples. Elevated nitrotyrosine levels were paralleled by an increase in plasma concentrations of $\mathrm{NO}$-oxidation products $\left(\mathrm{NO}_{\mathrm{x}}\right)$, nitrite and nitrate from $15.1 \pm 6.1 \mu \mathrm{M}$ in controls to $61.0 \pm 28.2 \mu \mathrm{M}$ in coeliac disease patients. Both nitrotyrosine and $\mathrm{NO}_{\mathrm{X}}$ levels declined when the patients were on a gluten free diet, suggesting a relation between intestinal inflammation and plasma nitrotyrosine and $\mathrm{NO}_{\mathrm{x}}$ levels.

\section{INTRODUCTION}

The production of nitric oxide (NO), a diffusible gas with a short half life, is enhanced during inflammation. In an aqueous solution as plasma, the reaction of NO and oxygen yields nitrite (1). Serum nitrite is in turn rapidly oxidized to nitrate, which is subsequently eliminated by renal excretion (2). Therefore, serum nitrate and nitrite $\left(\mathrm{NO}_{\mathrm{x}}\right)$ levels are used as markers for NO synthesis. However, considering the relatively short half life of approximately 1.5 hour in plasma, increased concentrations of $\mathrm{NO}_{\mathrm{x}}$ will only indicate ongoing $\mathrm{NO}$ production $(2,3)$.

Recently, nitrotyrosine has been identified as a additional marker of inflammation and enhanced NO production. Nitrotyrosine is the stable endproduct of nitration of tyrosine by peroxynitrite or NO in combination with other radicals. Peroxynitrite is a very strong oxidant and product of the reaction of NO with superoxide, which is also produced during inflammation (4). Peroxynitrite is highly toxic due to its ability to oxidize sulfhydryl groups, lipids, proteins, enzymes and DNA $(5,6)$. Nitration of the ortho position of tyrosine is a major product of peroxynitrite attack on proteins (7), leading to nitrotyrosine. Since nitrotyrosine is a stable endproduct of peroxynitrite oxidation, assessment of its plasma concentration may be useful as a marker of NOdependent damage in vivo (7-9). Since $\mathrm{NO}_{x}$ is only an indicator for enhanced $\mathrm{NO}$ production, protein associated nitrotyrosine might be a more suitable marker for 
damage induced by reactive nitrogen intermediates derived from NO. Furthermore, most proteins have a longer half life in the circulation than $\mathrm{NO}_{X}$ levels.

Several studies have shown the presence of nitrotyrosine in various tissues in inflammatory disorders (10-12). Using immunohistochemical techniques, we have demonstrated the presence of nitrotyrosine in intestinal biopsy tissue from patients with coeliac disease (13). However, the detection of nitrotyrosine in biological fluids such as blood and urine has only been sporadically investigated. Elevated levels of free nitrotyrosine in the synovial fluid of patients with rheumatoid arthritis and in plasma of patients with both chronic renal failure and septic shock have been demonstrated $(14,15)$. We report here the generation of two anti-nitrotyrosine monoclonal antibodies which can be used for immunohistochemical staining and Western blot analyses. Furthermore, we describe the development of a highly sensitive ELISA with these antibodies for the determination of nitrated proteins in biological fluids such as plasma or serum. Using this sandwich ELISA, we observed elevated levels of nitrated proteins in plasma samples of patients with coeliac disease, which is characterized by a severe inflammation of the small intestine (16-19).

\section{MATERIAL AND METHODS}

\section{Reagents}

Keyhole limpet hemocyanin (KLH), bovine serum albumin (BSA), lipopolysaccharide (LPS) from E. Coli (O55:B5), 3-chlorotyrosine, phenylalanine, tyrosine, sodium hydrosulfite (dithionite), sodium nitrite and Tween-20 were obtained from Sigma (St Louis, MO); 3-nitro-L-tyrosine was from Janssen Chimica (Geel, Belgium). Specoll was from the Central Veterinary Institute (Lelystad, The Netherlands). Biotin was from Calbiochem (La Jolla, CA); 96-wells microtitre ELISA plates were from Nunc (Roskilde, Denmark); tissue culture plates were from Costar (Cambridge, MA). RPMI 1640, Penicillin, Streptomycin, glutamine, and HAT supplement $(100 \mu \mathrm{M}$ sodiumhypoxanthine, $400 \mathrm{nM}$ aminopterin, $16 \mu \mathrm{M}$ thymidine) were obtained from Gibco BRL (Gaithersburg, MD). Bovine calf serum (BCS) was acquired from Hyclone (Logan, UT). Mouse monoclonal antibody isotyping kit (dipstick format) and rat IFN- $\gamma$ were from Hbt (Uden, The Netherlands). Human IgG was obtained from the CLB (Amsterdam, the Netherlands). B-mercaptoethanol, sulphuric acid, hydrogen peroxide were obtained from Merck (Darmstadt, FRG), 3,3-diaminobenzidine was obtained from Serva (Heidelberg, FRG). NADPH and nitrate reductase were obtained from Boehringer Mannheim (Mannheim, FRG). Peroxidase conjugated anti-human albumin was from Cappel (West Chester, PA). Peroxidase conjugated anti-human IgG and peroxidase conjugated goat anti-mouse IgG were from Jackson Immuno-Research (Westgrove, PA). Murine ABC kit was from Vectastain (Vector Laboratories Inc, Burlingame, CA). Rabbit anti-mouse iNOS antiserum was kindly provided by Dr. J. 
Cohen, Royal Postgraduate Medical School (London, UK) (20). Human serum was kindly provided by the Red Cross Blood Bank Zuid-Limburg (Maastricht, The Netherlands). Blood was donated after informed consent for research was obtained. Phastgels 10-15 and the LMW electrophoresis calibration kit were obtained from Pharmacia (Upsala, Sweden) and Immobilon-P transfermembranes for protein (Western) blotting applications from Müllipor Corporation (Bedford, MA).

\section{Nitrotyrosine formation in proteins}

Proteins were nitrated according to Ohshima et al. (21) with minor modifications. In short, the $\mathrm{pH}$ of $5 \mathrm{mg} / \mathrm{ml} \mathrm{KLH}$, IgG, BSA or $5 \%$ plasma in bidest was adjusted to $\mathrm{pH}$ 3.5 with acetic acid. Sodium nitrite $(200 \mathrm{mM})$ was added to a final concentration of 1 $\mathrm{mM}$ and the solution was incubated ratating at $37^{\circ} \mathrm{C}$ for 24 hours. The solutions changed colour from colourless to yellow after this incubation, indicating the presence of nitrotyrosine. Subsequently, the solutions were dialyzed overnight to PBS. The amount of nitrated proteins was determined spectrophotometrically.

\section{Spectrophotometric analysis}

3-Nitrotyrosine is a stable product and can easily be determined spectrophotometrically. Its absorbance maximum ranges from 350 to $450 \mathrm{~nm}$, shifting from $365 \mathrm{~nm}$ at acidic $\mathrm{pH}(\mathrm{pH}<3$, colourless) to $428 \mathrm{~nm}$ at basic $\mathrm{pH}(\mathrm{pH}>9$, yellow) $(8,22,23)$. The absorbance spectrum of a series of known concentrations of nitrotyrosine at acidic $\mathrm{pH}$ and basic $\mathrm{pH}$ were used as reference to determine the concentration of nitrotyrosine in our nitrated BSA, IgG and plasma samples. This method is accurate for samples containing a single pure protein such as BSA and IgG. Nitrated BSA and $\operatorname{IgG}(5 \mathrm{mg} / \mathrm{ml})$ give the same absorbance peaks as pure nitrotyrosine at acidic and basic $\mathrm{pH}$. However, for plasma samples containing multiple proteins this method is less suitable, because serum contains compounds that absorb light at 365 $\mathrm{nm}$ and because of the absorbance spectrum of these various nitrated proteins results in a less clear absorbance spectrum as compared to a single pure protein (24). The nitrotyrosine concentration in our nitrated $\operatorname{IgG}$ sample was approximately $136 \mu \mathrm{M}$ nitrotyrosine, and two different batches of nitrated BSA contained $175 \mu \mathrm{M}$ and 220 $\mu \mathrm{M}$ nitrotyrosine, respectively. The absorbance spectrum of plasma at acidic $\mathrm{pH}$ could not be determined accurately. The concentration of nitrotyrosine in plasma determined at $\mathrm{pH}>9$ was approximately $540 \mu \mathrm{M}$, which was confirmed by using nitrated IgG as standard curve in the newly developed nitrotyrosine ELISA.

\section{Animals}

Female BALB/C mice (2-6 months) were obtained from Charles River Breeding Laboratories (Heidelberg, FRG), maintained on standard laboratory diet and allowed 
free access to water. Guidelines of the Committee for Care and Use of Laboratory Animals from the Maastricht University were followed throughout.

\section{Monoclonal antibody production}

Mice were immunized with $10 \mu \mathrm{g}$ nitrated $\mathrm{KLH}$ in PBS. For the first two immunizations, the KLH solution was emulsified with an equal volume of Specoll. Each mouse received $0.5 \mathrm{ml}$ intraperitoneally. This treatment was repeated every week. Ten days after the thirth immunization blood was sampled by an orbital punction and the serum was tested by ELISA for binding to nitrated BSA, the lack of binding to unmodified BSA and blockage of binding by preincubation with $5 \mathrm{mM}$ nitrotyrosine.

After a high titer of anti-nitrotyrosine antibodies was detected in the serum, mice were immunized with nitrated KLH in the spleen. Five days after this immunization the mice were sacrificed and the spleen cells were fused with the non-secreting cell line SP20. After fusion cells were seeded into 96-wells tissue culture plates, containing $\mathrm{BALB} / \mathrm{C}$ mouse peritoneal macrophages in culture medium consisting of RPMI 1640 with $20 \% \mathrm{BCS}, 5^{*} 10^{-4} \mathrm{M} B$-mercaptoethanol, $100 \mathrm{U} / \mathrm{ml}$ penicillin, 100 $\mu \mathrm{g} / \mathrm{ml}$ streptomycin, $2 \mathrm{mM}$ glutamine and $\mathrm{HAT}$, and incubated at $37^{\circ} \mathrm{C}$ with $5 \% \mathrm{CO}_{2}$. The supernatants were screened for binding to nitrated BSA, lack of binding to unmodified BSA and blockage of binding by preincubation with $5 \mathrm{mM}$ nitrotyrosine. Positive cells were cloned by limited dilution. The antibodies were designated monoclonal after at least three limited dilutions which showed a $100 \%$ of the clones positive for the antigen. Two suitable clones, HM.11 and HM.12, both murine $\operatorname{IgG}_{1}$ producers, were cultured and monoclonal antibodies were purified with protein $\mathrm{G}$ chromatography. The elution fraction was dialyzed to PBS, filtered $(0.2 \mu \mathrm{M})$ and stored sterile. Antibody binding to nitrated BSA was prevented by preincubation with $5 \mathrm{mM}$ nitrotyrosine whereas no inhibition of binding to nitrated BSA was observed after preincubation with $5 \mathrm{mM}$ tyrosine, 3-chlorotyrosine or phenylalanine.

\section{Stimulation of RAW264.7 cells}

RAW264.7 cells (a murine macrophage cell line) were cultured in RPMI containing $10 \% \mathrm{BCS}, 100 \mathrm{U} / \mathrm{ml}$ penicillin, $100 \mu \mathrm{g} / \mathrm{ml}$ streptomycin and $2 \mathrm{mM}$ glutamine. Cells were plated in a 24 -wells plate at $2 * 10^{5}$ cells/well the day before stimulation. Cells were stimulated with rat IFN- $\gamma(100 \mathrm{u} / \mathrm{ml})$ and LPS $(1 \mu \mathrm{g} / \mathrm{ml})$ for 24,48 or 120 hours. Nitrite levels were determined in the supernatant and immunohistochemical staining for NOS and nitrotyrosine was performed on the cells. 


\section{Plasma $\mathrm{NO}_{\mathrm{X}}$ (nitrite and nitrate) levels}

After reducing nitrate to nitrite with bacterial nitrate reductase, plasma nitrite levels were determined as indicator of NO synthesis, using a microtitre plate assay method, based on the Griess reaction (25). In short, $30 \mu$ plasma, $10 \mu \mathrm{N}$ NDPH $(0.75 \mathrm{U} / \mathrm{ml})$ and $10 \mu 1$ nitrate reductase $(0.5 \mathrm{U} / \mathrm{ml})$ were incubated in a 96 -well microtitre plate for 20 min at room temperature (RT). Next, $50 \mu$ ] Griess reagent, which consists of 1 part $0.1 \% N-(1-n a p h t h y l)$-ethylenediamine dihydrochloride in distilled water and 1 part $1 \%$ sulfanilamide in $5 \%$ concentrated $\mathrm{H}_{3} \mathrm{PO}_{4}$, was added and incubated for 10 min at $\mathrm{RT}$. The absorbance at $540 \mathrm{~nm}$ was determined using a microwell plate reader. The amount of nitrite was calculated from a $\mathrm{NaNO}_{2}$ standard curve prepared in plasma.

\section{Immunohistochemical staining}

Cytospins of approximately $10^{5}$ cells were made, fixed with acetone $\left(-20^{\circ} \mathrm{C}\right)$ for 10 min and air dried. Endogenous peroxidase was blocked by immersing the slides in $0.3 \% \mathrm{H}_{2} \mathrm{O}_{2}$ in PBS (or methanol for intracellular staining) for $30 \mathrm{~min}$ followed by washing in PBS (three washes, 5 min each). After blocking non-specific binding by incubation with $5 \% \mathrm{BSA}$ for $30 \mathrm{~min}$ and subsequent washing, slides were incubated for 2 hours with biotin labeled murine anti-nitrotyrosine monoclonal antibodies (HM.11 and HM.12). Next, the slides were washed and incubated with freshly prepared avidin-biotin-peroxidase for $45 \mathrm{~min}$.

For iNOS staining slides were incubated for 1 hour with rabbit anti-iNOS serum. Normal rabbit serum was used as negative control. Next, the sections were washed with PBS and incubated for 1 hour with biotin labeled goat anti-serum to rabbit lgG and subsequently incubated for $45 \mathrm{~min}$ with freshly prepared avidin-biotin-peroxidase. Peroxidase activity was detected using diaminobenzidine as substrate. Slides were counterstained with hematoxylin, dehydrated, and mounted.

\section{SDS-PAGE and Western blotting}

Reduced normal and nitrated plasma and IgG samples were separated using the Phastsystem of Pharmacia (Upsala, Sweden) on a Phastgel with a continuous gradient from 10 to $15 \%$ polyacrylamide according to the manufacturers instructions. Two identical gels were run at the same time. One was submitted to Coomassie blue staining and the other was used for blotting onto a transfer membrane. Blotting was performed using the semi-dry electrophoric Phastransfer system of the Phastsystem according to the manufacturers instructions. Non-specific sites of the membrane were blocked with $5 \% \mathrm{BSA}$ for 1 hour shaking at $37^{\circ} \mathrm{C}$. Next, the membrane was incubated with anti-nitrotyrosine antibody for 1 hour shaking at $37^{\circ} \mathrm{C}$. After washing the blots with PBS containing $0.1 \%$ BSA and $0.05 \%$ Tween, the blots were incubated with 
peroxidase-conjugated goat anti-murine antibodies. After subsequent washings, peroxidase activity was detected using diaminobenzidine as substrate.

\section{Nitrotyrosine ELISA}

Plates were coated with $1 \mu \mathrm{g} / \mathrm{ml} \mathrm{HM} .12$ in PBS $\left(100 \mu \mathrm{l} /\right.$ well) overnight at $4^{\circ} \mathrm{C}$. After blocking with $1 \% \mathrm{BSA}(150 \mu \mathrm{l} /$ well) and washing with bidest containing $0.1 \%$ tween, the plates were incubated with nitrated proteins as antigen $(100 \mu / /$ well $)$ for one hour. Next, the plates were incubated with biotin labeled HM.12 diluted 1:1000 in PBS containing $0.1 \%$ BSA ( $100 \mu \mathrm{l} /$ well) for 1 hour. Subsequently, plates were incubated with streptavidin peroxidase conjugate followed by TMB. The reaction was stopped after 10 to 15 min by addition of $1 \mathrm{mM} \mathrm{H}_{2} \mathrm{SO}_{4}$.

\section{Samples of coeliac disease patients and controls}

In total 19 plasma samples were obtained from 12 children with coeliac disease. Five samples were obtained from acute coeliac clisease patients (mean age 18.2 \pm 7.8 months) and three samples were obtained from patients submitted to a gluten challenge for 3 months (mean age $52.3 \pm 15.9$ months). Three samples were obtained from patients screened for coeliac disease but without the classical symptoms of coeliac disease (mean age of $70.7 \pm 25.8$ months). One of these patients was screened because a family member was diagnosed with coeliac disease and the other two were screened because of failure to grow and aspecific abdominal complaints. Eight further samples were taken after at least 6 months of gluten free diet (mean age $45.8 \pm 18.3$ months). Duodenal biopsy material of all above mentioned patients on a gluten containing diet showed total atrophy of the intestine which recovered on a gluten free diet. Furthermore, all patients showed elevated levels of anti-gliadin and antiendomysium antibodies, which disappeared on gluten free diet. Plasma samples were obtained from 4 control subjects (mean age $32.8 \pm 13.9$ months), who were screened for coeliac disease because of failure to grow or aspecific abdominal complaints. After histological examination no intestinal abnormalities were observed in these subjects and they were all negative for anti-gliadin and anti-endomysium antibodies. Further, plasma samples from 4 adults kindly provided by the Red Cross Blood Bank ZuidLimburg (Maastricht, the Netherlands) were used as controls.

\section{Statistical analysis}

The Mann-Whitney test was used to determine the statistical significance of difference found between coeliac disease patients and controls. $P<0.05$ was considered statistically significant. 


\section{RESULTS}

\section{Immunohistochemical staining with HM.11 and HM.12}

Two different hybridoma clones HM.11 and HM.12, which showed binding to nitrated BSA, lack of binding to unmodified BSA and inhibition of binding to nitrated BSA after preincubation with $5 \mathrm{mM}$ nitrotyrosine were selected and IgG was purified by affinity chromatography. The usefulness of these anti-nitrotyrosine monoclonal antibodies for histological staining of nitrated proteins in tissues and cells was determined by staining cytospins of stimulated RAW cells, a murine macrophage like cell line. RAW cells are capable of producing nitric oxide and superoxide after IFN- $\gamma$ and LPS stimulation and are, therefore, expected to contain nitrotyrosine after activation. In culture medium of unstimulated RAW cells a constant level of approximately $3 \mu \mathrm{M}$ nitrite was observed whereas, after LPS stimulation for 24,48 , and 72 hours, nitrite levels were elevated to $18.77,22.1$ and $22 \mu \mathrm{M}$, respectively (not shown). Elevated levels of iNOS expression were demonstrated by staining with rabbit anti-murine iNOS antiserum (Figure $1 \mathrm{~A}$ and $\mathrm{C}$ ).

Figure 1. Immunohistochemical staining of cytospins of RAW cells with (A) normal rabbit serum (negative control iNOS), (B) with biotin labeled murine nonsense antibody (negative control nitrotyrosine), (C) rabbit anti-murine iNOS antiserum and (D) murine antinitrotyrosine monoclonal antibody HM.11. Original magnification $400 x$.
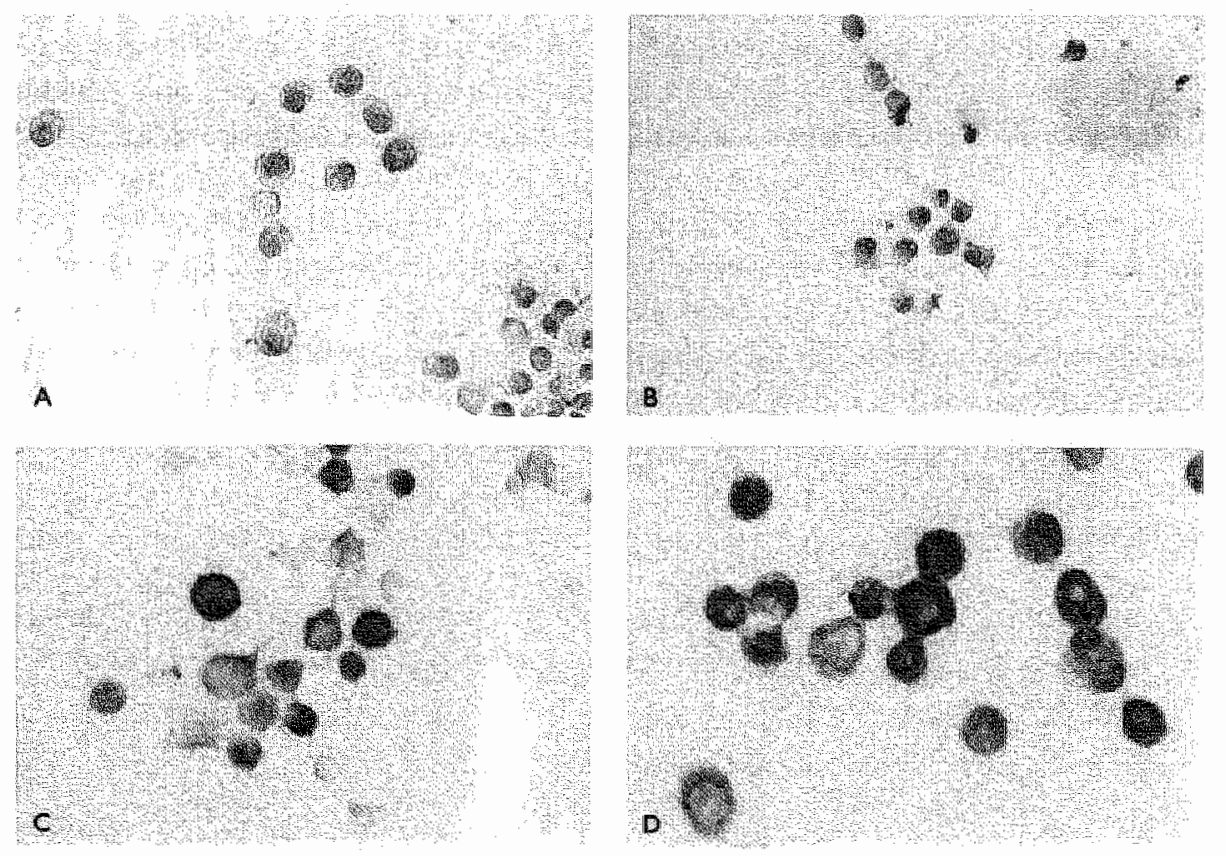
Intra-cellular as well as membrane nitrotyrosine staining were detected using biotin labeled HM.11 and HM.12 (data not shown) after 24, 48 and 72 hours after stimulation (Figure $1 \mathrm{~B}$ and D). Staining was prevented by preincubation of the monoclonal antibodies with $5 \mathrm{mM}$ nitrotyrosine (data not shown).

\section{Western blot analyses of nitrated proteins}

Nitration of plasma proteins was confirmed by SDS-PAGE and Western blotting. Figure 2 shows an example of a Coomassie blue stained gel and the twin immunoblot stained with the anti-nitrotyrosine antibody HM.12. Nitrotyrosine is undetectable in normal human plasma (lane F) and human $\operatorname{IgG}$ (lane $\mathrm{H}$ ). In contrast a clear signal is observed in nitrated plasma (lane G) and IgG (lane I) samples. Most nitrated plasma proteins have a relatively high molecular weight $(>66 \mathrm{kDa}$ ). Surprisingly, no nitrotyrosine staining is detected at approximately $66 \mathrm{kDa}$ which should represent serum albumin. Since albumin contains 19 tyrosine residues and is the most abundant protein in serum this result might suggest that nitrotyrosine formation in serum mainly affects proteins with a relatively high molecular weight. Positive staining of the blots was blocked by preincubation of HM. 12 with $5 \mathrm{mM}$ nitrotyrosine and by treatment of the blot with $10 \mathrm{mM}$ dithionite, which is known to reduce nitrotyrosine to aminotyrosine, illustrating the specificity of the anti-nitrotyrosine antibodies $(10,24$, 26,27).

Figure 2. Representative Coomassie blue stained gel and Western blot of normal human plasma and IgG and nitrated human plasma and $\lg G$ stained with HM.12. Protein gel; lane A: molecular weight markers, B: normal human serum (diluted 1:40). C: nitrated human serum (1:40), D: normal human $\lg G(2.5 \mathrm{mg} / \mathrm{ml})$, E: nitrated human $\lg G(2.5 \mathrm{mg} / \mathrm{ml})$. Western blot twin gel; $F$; normal human serum $G$ : nitrated human serwm, H: normal human $\lg G$, I: nitrated human $\lg G$.

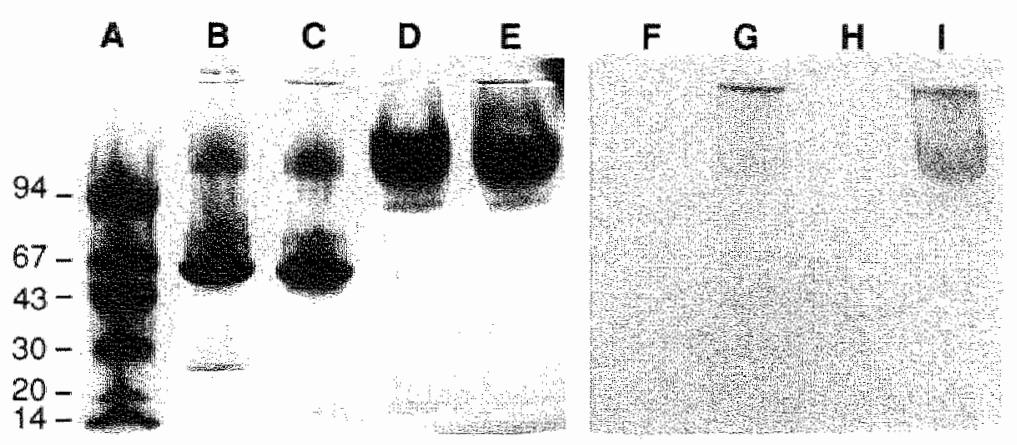




\section{Development of a nitrotyrosine ELISA}

To determine the usefulness of these antibodies in an ELISA, the use of both antibodies as coating antibody was tested. Plates were coated with HM.11 and HM.12 overnight at $4^{\circ} \mathrm{C}$. After blocking the plates with $1 \% \mathrm{BSA}$ and subsequent washings, the plates were incubated with a concentration curve of biotin-labeled nitrated BSA or nitrated IgG as antigen. A streptavidin peroxidase conjugate incubation was followed by TMB. Both antibodies were useful to detect biotin-labeled nitrated BSA and nitrated $\operatorname{IgG}$ in a concentration dependent manner (data not shown).

Figure 3. Both HM.II and HM.12 (I $\mu \mathrm{g} / \mathrm{ml})$ are useful as coatings antibody for nitrated proteins present in plasma. Open circles represent HM.ll as coating antibody, closed circles represent HM. 12 as coating antibody, open diamond represents the background of the ELISA for both antibodies. (A) Dilution of nitrated IgG (highest concentration $5 \mu \mathrm{g} / \mathrm{ml}$ ) in normal serum (l\%) with peroxidase conjugated anti-human IgG as detection antibody, (B) dilution of nitrated serum (start 1\%) with peroxidase conjugated anti-human albumin as detection antibody.
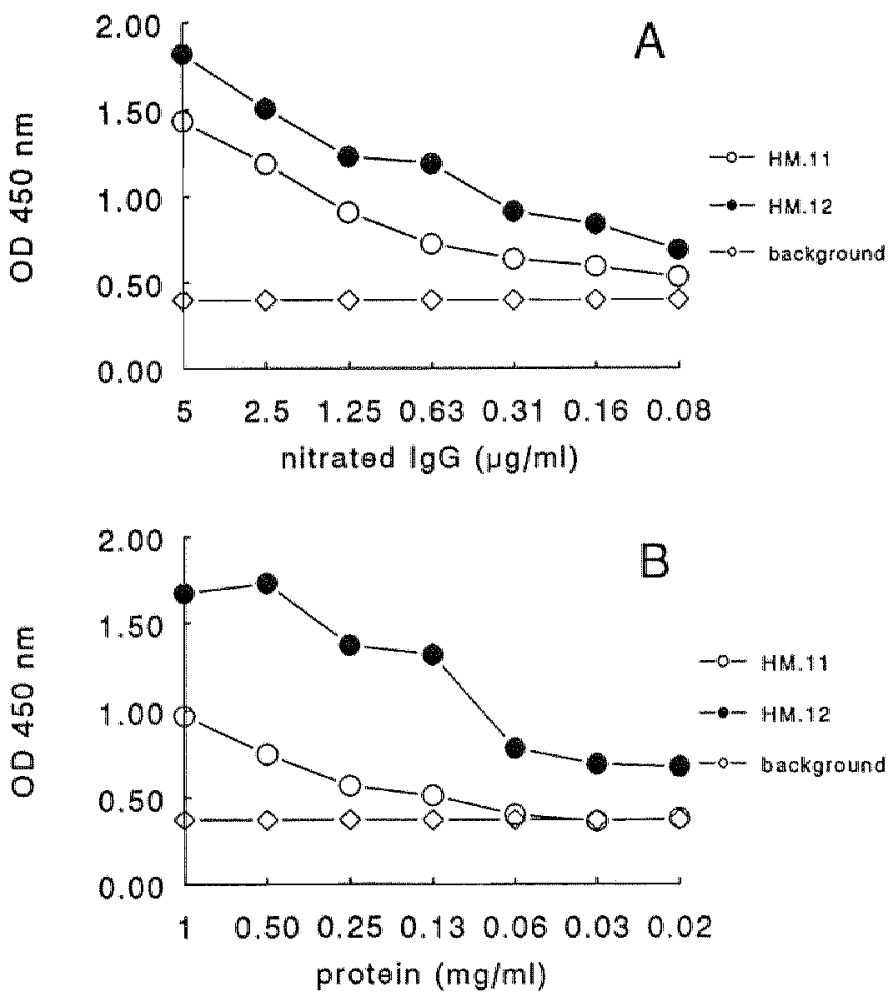
Next, the efficacy of these antibodies to detect nitrated proteins in human plasma was investigated. The plates were coated, blocked and washed as described for the first experiment. A concentration curve of nitrated human plasma or nitrated human $\operatorname{lgG}$ diluted in normal human plasma was used as antigen. Peroxidase conjugated antihuman albumin and anti-human IgG were used as detection antibodies. As shown in Figure 3, HM.11 as well as HM.12 was able to detect nitrated albumin and nitrated $\mathrm{IgG}$ from human plasma samples in a concentration dependent manner.

Since proteins can contain more than one tyrosine residue, it is conceivable that nitrated proteins contain several nitrotyrosine molecules. Based on this assumption and on our finding that both antibodies are useful as coatings as well as detector antibody (see material and methods) of nitrated proteins, we set out to develop a sandwich ELISA for the detection of nitrated proteins in plasma samples. To this end, all combinations of HM.11 and HM.12 as coating as well as detector antibody were evaluated. Usage of HM.12 both as coating and detector antibody resulted in an ELISA with a detection limit of approximately $0.2 \mathrm{nM}$ nitrotyrosine (Figure 4).

Figure 4. Representative standard curve of nitrated human plasma (open circles) in the newly developed nitrotyrosine ELISA. Values were determined in duplicate. One representative experiment is shown. Mean background $A_{450}+3 \times S D$ (dashed line) is indicated as the background.

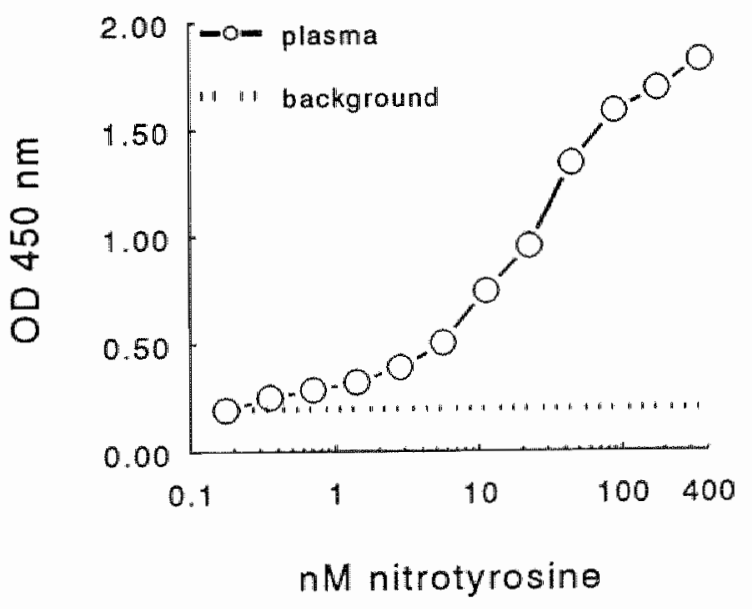

To verify the specificity of the ELISA two control experiments were performed. The first control experiment consisted of preincubation of the samples with different concentrations of nitrotyrosine (data not shown). The second control involved preincubation of the detection antibody with different concentrations of nitrotyrosine 
before addition to the ELISA (Figure 5). In both control experiments a concentration dependent inhibition of the signal was observed, indeed demonstrating the specificity of the nitrotyrosine sandwich ELISA. Plasma samples tested in this nitrotyrosine ELISA were diluted 10 to 20 times.

Figure 5. Preincubation of biotin labeled HM.12 with a concentration range of nitrotyrosine before addition of the detection antibody in the newly developed nitrotyrosine ELISA inhibits the signal in a concentration dependent way, confirming the specificity of the detection antibody.

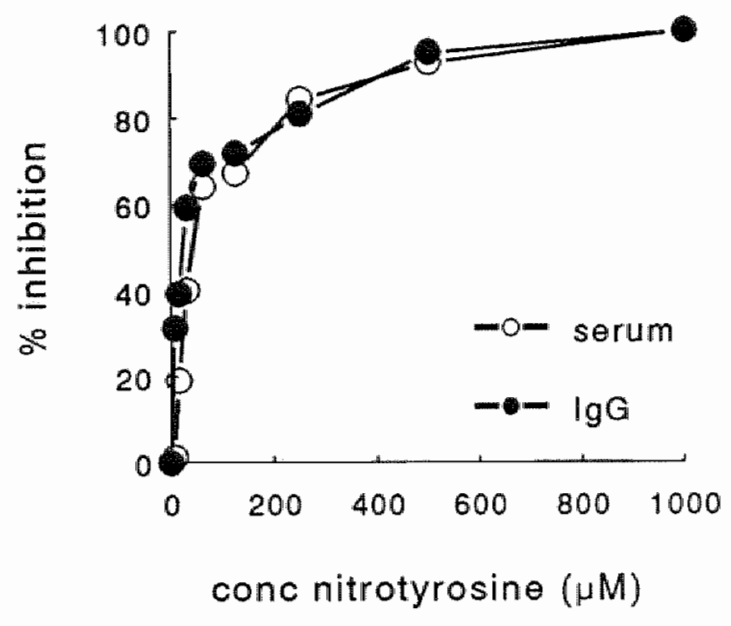

For validation of the ELISA, the inter- and intra-assay variance was determined, by comparison of the reproducibility of the nitrotyrosine (nitrated plasma) standard within individual experiments and between experiments, respectively. The interassay variance was determined by calculation of the average $A_{450}$ of the first two standard curves in each plate and use it as a reference curve to calculate the nitrotyrosine concentrations of the next three standard curves in the same microtitre plate (Table 1). The intra-assay variance was determined by calculating the coefficients of the variance of the mean nitrotyrosine levels measured in five separate microtitre plates. The mean interassay variance of this nitrotyrosine ELISA is $11.9 \%$ and the mean intra-assay variance is $2.4 \%$ (Table 1 ). 
Table 1. Inter-and intra-assay variance of nitrotyrosine ELISA

\begin{tabular}{|c|c|c|c|c|c|c|}
\hline $\begin{array}{l}\text { nitrotyrosine } \\
\text { niM }\end{array}$ & $\begin{array}{l}\text { Intra-assay } \\
\text { Mean (nM) }\end{array}$ & $\mathrm{SD}$ & $\begin{array}{l}C V^{c} \\
(\%)\end{array}$ & $\begin{array}{l}\text { Interassay } \\
\text { Mean (nM) }\end{array}$ & SD & $\begin{array}{l}\mathrm{CV}^{\mathrm{C}} \\
(\%)\end{array}$ \\
\hline 270 & 271.8 & 3.2 & 1.1 & 280.7 & 15.3 & 5.6 \\
\hline 135 & 135.1 & 5.2 & 3.8 & 131.1 & 7.6 & 5.7 \\
\hline 675 & 67.0 & 1.3 & 1.9 & 63.2 & 4.4 & 6.9 \\
\hline 338 & 34.8 & 1.4 & 4.0 & 32.6 & 3.0 & 9.2 \\
\hline 169 & 16.8 & 0.06 & 0.3 & 16.3 & 0.52 & 3.1 \\
\hline 844 & 7.22 & 1.2 & 1.6 & 7.50 & 1.0 & 13.2 \\
\hline 422 & 3.57 & 1.4 & 3.9 & 3.63 & 0.88 & 24.3 \\
\hline 211 & 1.63 & 0.52 & 3.1 & 1.90 & 0.51 & 27.0 \\
\hline
\end{tabular}

${ }^{3}$ Results of one representative experiment from a series of five experiments is shown. Mean and SD of nitrotyrosine concentrations in concentration curve of nitrated human plasma measured in triplicate, in one 96-well microtitre plate, are presented.

${ }^{b}$ Mean and SD of nitrotyrosine concentrations measured in five separate experiments are shown.

${ }^{c}$ Coefficient of variance $\mathrm{CV}=\mathrm{SD} / \mathrm{mean} \times 100 \%$

Table 2. Serum NO and nitrotyrosine levels in coeliac disease patients and controls ${ }^{\text {. }}$.

\begin{tabular}{lccc} 
& $\mathrm{N}^{\mathrm{b}}$ & $\mathrm{NO} \mu \mathrm{M}$ & nitrotyrosine nM \\
\hline controls (infants) & 4 & $15.1 \pm 6.1$ & not detectable \\
controls (adults) & 4 & $12.8 \pm 5.6$ & not detectable \\
gluten containing diet & 10 & $61.0 \pm 28.2^{\mathrm{c}}$ & $1272.6 \pm 1031.7$ \\
gluten free diet & 8 & $21.8 \pm 12.6^{\mathrm{d}}$ & $5.46 .4 \pm 746.8$ \\
\hline
\end{tabular}

a determined with Mann-Whitney test

bumber of samples

"p $<0.004$ as compared to control values

${ }^{2}<0.002$ as compared to coeliac disease patients on a gluten containing diet 


\section{Plasma $\mathrm{NO}_{\mathrm{X}}$ and nitrated protein levels in coeliac disease patients}

Plasma $\mathrm{NO}_{x}$ levels in coeliac disease patients on a gluten containing diet were found to be significantly elevated to $61.0 \pm 28.2 \mu \mathrm{M}$ as compared with levels detected in controls $15.1 \pm 6.1 \mu \mathrm{M}(\mathrm{p}<0.004$, Table 2). Plasma $\mathrm{NO}$ levels significantly decreased to normal levels on a gluten free diet for at least 6 months $(21.8 \pm 12.6 \mu \mathrm{M}$, Table 2). In three patients sequential plasma $\mathrm{NO}_{\mathrm{x}}$ levels could be determined first on a glluten containing diet and subsequently on gluten free diet. Results from these determinations confirm that plasma $\mathrm{NO}_{\mathrm{X}}$ levels decrease with time after elimination of gluten from the diet (Figure 6A).

Figure 6. Elevated serum NO levels (A) and nitrotyrosine (B) in patients with acute coeliac disease decline to normal levels on a gluten free diet. Serum $\mathrm{NO}_{x}$ and nitrotyrosine levels of 3 individual patient on gluten containing diet $(0)$ and at different time points after the start of a glwen free diet are depicted. Open symbols represent the patients and closed symbols represent the mean 2 SD of the controls.
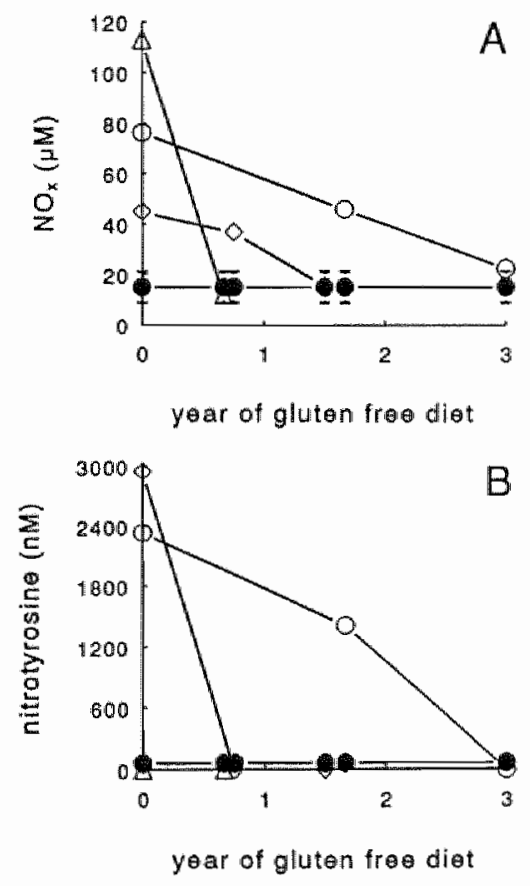

In a previous study, we demonstrated that elevated iNOS expression correlates with expression of nitrotyrosine in the small intestine of coeliac disease patients (13). Here, we investigated whether nitrotyrosine is also detectable systemically in these patients. 
From the 10 patients on a gluten containing diet 6 were positive for plasma nitrotyrosine as detected by ELISA with a mean value of $1272.4 \pm 1031.7 \mathrm{nM}$ nitrotyrosine with a range from $73.4 \mathrm{nM}$ to $2.3 \mu \mathrm{M}$ (Table 2). Three of these 10 patients were screened for coeliac disease, without showing any of the classical symptoms. In two of these three patients plasma nitrotyrosine could not be detected. In summary, five of the seven $(71.4 \%)$ coeliac disease patients with severe and characteristic symptoms showed elevated nitrotyrosine levels in plasma. In contrast, in the control population ( 4 infant and 4 adult plasma samples) nitrotyrosine could not be detected using this ELISA, supporting that the concentrations of nitrated proteins are significantly elevated in blood of patients with coeliac disease. Further, from the 8 samples obtained from 6 different patients on a gluten free diet for at least 6 months only $3(37.5 \%)$ were positive for plasma nitrotyrosine, suggesting that plasma levels of nitrated proteins decline slowly on a gluten free diet (Figure 6B and Table 2). Two of these three positive samples were obtained from the same patient after a gluten free dietary period of 1.5 and 2 years, respectively. The other positive sample originated from a patient on a gluten free diet for 14 months. A sample of this last patient obtained after 3 years on a gluten free diet was found to be negative for nitrotyrosine, supporting earlier results that plasma nitrotyrosine levels decrease in time on a gluten free diet.

\section{DISCUSSION}

Ohshima et al. (21) were the first to propose nitrotyrosine as an in vivo marker for nitration. Subsequently, polyclonal and monoclonal anti-nitrotyrosine antibodies were developed and the presence of nitrotyrosine was demonstrated immunohistologically in various tissues such as atherosclerotic plaques (10), lung tissue of infants with acute lung injury and sepsis (28), lung tissue of adults with respiratory distress syndrome (ARDS) (12) and intestinal tissue of coeliac disease patients (13). Although the use of antibodies is very helpful in localizing nitrotyrosine in tissues and identifying nitrated proteins in Western blots, it is difficult to quantitate nitrotyrosine using these techniques.

It would, therefore, be of interest to determine whether the local formation of nitrotyrosine during the above mentioned inflanmatory processes is also systemically detectable which would simplify quantification. Nitrotyrosine has been identified in biological fluids, such as plasma and urine, using various expensive and time consuming techniques like HPLC and gaschromatography $(14,15,21,27,29)$. The advantage of these methods is that they can be very sensitive allowing quantification in the pM range. However, the disadvantage of these methods is that the samples have to undergo extensive processing which can give rise to artifacts. For example, the presence of a small amount of contaminating nitrite during acid hydrolysis necessary 
to release free tyrosine may result in additional nitration and consequently overestimation of the nitrotyrosine content (27).

We purified and characterized two monoclonal antibodies, HM.11 and HM.12, that specifically recognize nitrotyrosine. These antibodies can be used for immunohistological staining of cytospins of cells, of paraffin embedded tissue and of frozen tissue (data not shown). Specificity of these antibodies was determined by inhibition of staining by preincubation of the antibodies with $5 \mathrm{mM}$ nitrotyrosine. Furiher, these antibodies do not recognize other antigens with a nitrotyrosine like structure such as tyrosine, 3-chlorotyrosine and phenylalanine, illustrating the specificity of the antibodies.

Western blot analyses of nitrated human plasma samples demonstrated the presence of unknown nitrotyrosine containing proteins with a molecular weight above $66 \mathrm{kDa}$. Further, we did not detect nitrotyrosine in normal human plasma or IgG samples by Western blot analyses. Although in contrast with Khan et al. (30) who demonstrated that normal human plasma contains nitrotyrosine and that albumin $(66 \mathrm{kDa})$ was the main nitrated protein in human plasma, our results are supported by others who demonstrated that normal human plasma does not contain nitrotyrosine, using various other detection methods such as HPLC $(14,15,27)$. These contradictory results might be explained by the fact that Khan et al. (30) used a polyclonal antibody which in general shows substantially more cross reactivity than highly specific monoclonal antibodies. The specificity of our monoclonal antibodies is further illustrated by the fact that treatment of the blots with $10 \mathrm{mM}$ dithionite, which is know to reduce nitrotyrosine into aminotyrosine, completely blocks staining with our antibodies (10, $24,26,27)$.

With these monoclonal antibodies we developed an ELISA to determine nitrotyrosine present in plasma or serum. Using nitrated plasma or nitrated $\operatorname{IgG}$ as reference curve the sensitivity of this ELISA is approximately $0.2 \mathrm{nM}$ of nitrotyrosine. The relativaly high amount of nitrotyrosine $(400 \mu \mathrm{M})$ necessary for inhibition of the biotin labeled detection antibody HM.12 in comparison with the lower detection limit of $0.2 \mathrm{nM}$ of nitrotyrosime in proteins, suggests that the antibodies recognize nitrated proteins with clearly higher affinity than free nitrotyrosine. To further confirm the specilicity of this nitrotyrosine sandwich ELISA, plasma or serum samples were preincubated with nitrotyrosine $(5 \mathrm{mM})$ for $30 \mathrm{~min}$ before addition in the ELISA plates. Nitrated proteins and nitrotyrosine will compete for binding to the coating antibody and because of the fact that the amino acid nitrotyrosine is to small to bind both the coating antibody and the detection antibody, addition of nitrotyrosine should inhibit the signal. As expected preincubation with nitrotyrosine inhibited the signal in the ELISA confirming the specificity. Quantification of nitrotyrosine using this sandwich ELISA has the advantage of high sensitivity with a lower detection limit of $2 \mathrm{nM}$ in plasma and does not require sample processing. This assay allows simultaneous analysis of experimental and control samples, in contrast to other detection methods such as HPLC. Further, evaluation of the intra- and interassay 
coefficients of variance achieved with this ELISA demonstrated that these are comparable with those reported for other immunoassays (30-33). It is recognized that this ELISA only allows semi-quantitative quantification since human plasma samples are a composition of various nitrotyrosine containing proteins to which our antibodies might have different affinity. Moreover tyrosine, 3-chlorotyrosine and phenylalanine do not interfere with the ELISA, illustrating the specificity of this ELISA for nitrotyrosine.

Recently, Khan et al. (30) reported the development of a inhibition assay for determination of nitrotyrosine in plasma. In contrast to our results and those of others $(14,1.5,27,29)$, they detected nitrotyrosine levels in normal human plasma $(0.12 \mu \mathrm{M})$ using this ELISA. This difference might be explained by the highly specific monoclonal antibodies in our assay as compared to the polyclonal antibody in Khan's assay. Furthermore, in an inhibition assay as used by Khan et al. (30) every inferference with the polyclonal binding to coated nitrotyrosine leads to positive reading. On the other hand, our ELISA determines protein bound nitrotyrosine and not free nitrotyrosine. Free tyrosine is abundantly present in plasma and therefore is a major target for peroxynitrite oxidation (24). Skinner et al. (24) showed that the extent of nitrotyrosine formation by peroxynitrite in human plasma increased in a dose depend manner in both free and protein associated tyrosine. However, in contrast to protein associated nitrotyrosine is free nitrotyrosine rapidly cleared by renal excretion (15). Because of the fact that our antibodies exhibit a much higher affinity for protein associated nitrotyrosine than for free nitrotyrosine (inhibition $>400 \mu \mathrm{M}$ free nitrotyrosine) we expect that free plasma nitrotyrosine does not interfere in our ELISA. Further, because of the relatively short half life of free nitrotyrosine, is protein associated nitrotyrosine a more stable of nitrated tyrosine than free tyrosine, providing a more accurate determination of the extent of nitration.

Tyrosine nitration caused by peroxynitrite has been shown to inactivate enzymes and receptors that depend on tyrosine residues for their activity $(7,34)$. Further, peroxynitrite has been shown to decrease plasma anti-oxidant concentrations (35). In addition, it has been demonstrated that peroxynitrite has the ability to cause protein fragmentation and in this way induce tissue damage $(36,37)$. Recent studies indicated the existence of several peroxynitrite independent pathways by which $\mathrm{NO}$ and other radicals yield nitrotyrosine as a stable endproduct (10, 38-42). Therefore, quantification of nitrotyrosine provides insight into the importance of NO-derived metabolites in cellular toxicity rather than that of peroxynitrite mediated toxicity.

In a previous study, we demonstrated the presence of iNOS and nitrotyrosine in intestinal biopsy tissue of coeliac disease patients by immunohistochemical staining. Further, highly elevated urinary $\mathrm{NO}_{x}$, have been demonstrated in these patients (43). In this study, we report elevated plasma $\mathrm{NO}_{\mathrm{x}}$ and nitrotyrosine levels in these patients on a gluten containing diet. The existence of nitrotyrosine in plasma samples of coeliac disease patients is important indirect evidence which confirms our earlier hypothesis that NO is involved in the pathophysiologic processes of coeliac disease 
$(13,23)$. Both plasma $\mathrm{NO}_{\mathrm{x}}$ as well as nitrotyrosine levels normalize when these patients are on a gluten free diet and the intestinal inflammation disappears confirming the relation of enhanced NO and nitrotyrosine synthesis with intestinal inflammation.

To our surprise we were not able to detect nitrotyrosine in plasma (serum) samples of septic patients although we observed elevated plasma levels of $\mathrm{NO}_{\mathrm{x}}$ and increased nitrotyrosine expression in the lung were reported in these patients $(25,44-46)$. This might suggest that elevated nitrotyrosine levels depend on both increased NO and other radical levels and the duration thereof. In patients with acute conditions such as sepsis the duration of protein exposure may be to short for nitrotyrosine formation to appear in the circulation. This is in contrast with coeliac disease patients who have a long history of gluten exposure and thereby elevated NO and radical production before blood samples are screened and the diagnose is made.

This semi-quantitative assay for nitrated plasma proteins is a valuable completion of the existent immunohistological determination of nitrotyrosine. This assay quantitates the NO mediated systemical damage, thereby potentially extending the number of experiments designed to investigate the relation between NO production and various pathological conditions characterized by enhanced NO production. Measurement of protein associated nitrotyrosine with this sandwich ELISA might be a simple and useful method for demonstrating NO-mediated tissue damage and testing the effectiveness of therapeutic agents in preventing such damage.

\section{Acknowledgment}

This work was supported by a grant (1997-E5) from the Nutricia Research Foundation, The Hague, the Netherlands.

\section{REFERENCES}

1. Ignarro LJ, Fukuto JM, Griscavage JM, Rogers NE, Byrns RE. Oxidation of nitric oxide in aqueous solution to nitrite but not nitrate: Comparison with enzymatically formed nitric oxide from L-arginine. Proc Nal Acad Sci USA $90: 8103-8107,1993$.

2. Veszelovszky $\mathrm{E}$, Holford $\mathrm{NHG}$, Thomson $\mathrm{LL}$, Knowles $\mathrm{RG}$, Baguley BC. Plasma nitrate clearance in mice: modeling of the systemic production of nitrate following the induction of nitric oxide synthesis. Cancer Chemolher Phamacol 36:155-159, 1995.

3. Castillo L, Beammier L, Ajami AM, Young VR. Whole body nitric oxide synthesis in healthy men determined from [15] Narginine-to-[ $\left[{ }^{15} \mathrm{~N}\right]$ citrulline labeling. Proc Natl Acad Sci USA 93: 11460$11465,1996$.

4. Szabó C. The pathophysiological role of peroxynitrite in shock, inflammation, and ischemiarepertusion injury. Shock 6: 79-88, 1996.

5. Kubes $\mathbb{P}$, Wallace $\Omega$. Nitric oxide as a mediator of gastrointestinal injury ? - Say it ain't so. Med Inflamm 4: 397-405, 1995 .

6. Radi R, Beckman JS, Bush KM, Freeman BA. Peroxynitric oxidation of sulfhydryls. The cylotoxic potential of superoxide and nitric oxide. J Biol Chem 266:4244-4250, 1991. 
7. Ischiropoulos $\mathrm{H}$, Zhu L, Chen J, Tsai M, Martin JC, Smith CD, Beckman JS. Peroxynitritemediated tyrosine nitration catalyzed by superoxide dismutase. Arch Biochen Biophys 298:431$437,1992$.

8. Van der Vliet A, Eiserich JP, Kauer H, Cross CE, Halliwell B. Nitrotyrosine as a biomarker for reactive nitrogen species. Meth Enzymol 269: 175-184, 1996.

9. Salman-Tabcheh S, Guerin MC, Torreilles J. Nitration of tyrosyl-residues from extra-and intracellular proteins in human whole blood. Free Radical Biol Med 19: 695-698, 1995.

10. Beckmann JS, Ye YZ, Anderson PG, Chen J, Accavitti MA, Tarpey MM, White CR. Extensive nitration of protein tyrosines in human atherosclerosis detected by immunohistochemistry. Biol Chem 375: 81-88, 1994.

11. Kooy NW, Royall JA, Ye YZ, Kelly DR, Beckman JS. Evidence for in wivo peroxinitrite production in human acute injury. Am J Respir Crit Care Med 151: 1250-1254, 1995.

12. Haddad IY, Pataki G, Hu P, Galliani C, Beckman JS, Matalon S. Quantification of nitrotyrosine levels in lung sections of patients and animals with acute lung injury. $J$ Clin Imest $94: 2407-2413$, 1994.

13. Ter Steege J, Buurman W, Arends JW, Forget Ph. Presence of inducible nitric oxide synthase, nitrotyrosine, CD68 and CD14 in the small intestine in celiac disease. Lab lwwest 76: 1-8, 1997.

14. Kuar $H$, Halliwell B. Evidence for nitric oxide-mediated oxidative damage in chronic inflammation. Nitrotyrosine in serum and synovial fluid from rheumatoid patients. FEBS Lerters $350: 9-12,1994$.

15. Fukuyama N, Takebayashi $Y$, Hida M, Ishida H, Ichimori K, Nakazawa H. Clinical evidence of peroxynitrite formation in chronic renal failure patients with septic shock. Free Radical Bial Med 22: $771-774,1997$.

16. Marsh MN. Morphology and immunopathology of the jejunal lesion in gluten sensitivity. Eur $J$ Gastroenterol Hepathol 3: 108-1.14, 1992.

17. Marsh MN, Loft DE, Garner VG, Gordon DI. Time/dose response of coeliac mucasae to graded oral challenges with Frazer's fraction III of gliadin. Eur $J$ Gastroenterol Hepathol 4: 667-673, 1996.

18. Spencer J, MacDonald TT, Diss TC, Walker-Smith JA, Ciclitira PJ, Isaacson PG. Changes in intraepithelial Jymphocyte subpopulations in coeliac disease and enteropathy associated 'T cell lymphoma (malignant histiocytosis of the intestine). Gut 30:339-346, 1989.

19. Brandzaeg P. Halstensen TS, Kett K, Krajči P, Kvale D. Rognum TO, Scott H, Sollid LM. Immunobiology and immunopathology of human gut mucosa: humoral immunity and intraepitheliall lymphocytes. Gastroenterology $97: 1562-1584,1989$.

20. Buttery LDK. Evans TJ, Springdall DR, Carpenter A, Cohen J, Polak JM. Immunohistichemical locallization of inducible nitric oxide synthase in endotoxin-treated rats. Lab Invest 71: 755-764. 1994.

21. Ohshima H. Friesen M, Brouet I, Bartsch H. Nitrotyrosine as new marker for cndogenous nitrosation and nitration of proteins. Food Chem Toxicol 28; 647-652, 1990.

22. Crow JP, Ischiropoulos H. Detection and quantification of nitrotyrosine residues in proteins: in wiwo marker of peroxynitrite. Meth Enzymol 269:185-194, 1996.

23. Ye YZ, Strong M, Huang ZQ, Beckman JS. Antibodies that recognize nitrotyrosine. Meth Ensymol 269: 201-209, 1996.

24. Skinner KA, Crow JP, Skinner HB, Chandler RT, Thompson JA, Parks DA. Free and proteinassociated nitrotyrosine formation following rat liver preservation and transplantation. Arch Biochem Biophys 342: 282-288, 1997.

25. Green LC, Wagner DA, Glogowski J, Skipper PL, Wishnok JS, Tannenbaum ST. Analysis of nitrate, nitrite, and ( ${ }^{15} \mathrm{~N}$ )nitrate in biological fluids. Anal Biochem 126:131-138, 1982.

26. Haddad IY, Crow JP, Hu P, Ye X, Beckman J, Matalon S. Concurrent generation of nitric oxide and superoxide damages surfactant protein A. Am J Physiol 267: L242 L249, 1994. 
27. Shigenaga $\mathrm{MK}$, Lee $\mathrm{HH}_{4}$ Blount $\mathrm{BC}$, Shigeno $\mathrm{ET}$, Yip $\mathrm{H}$, Ames $\mathrm{BN}$. Inflammation and $\mathrm{NO}_{\mathrm{X}}$ induced nitration: Assay for 3-nitrotyrosine by HPLC with electrochemical detection. Proc Natl Acad Sci USA 94: 3211-3216,1997.

28. Wizemann TM, Gardner CR, Laskin JD, Quinones S, Durham SK, Goller NL, Ohnishi ST, Laskin DL. Production of nitric oxide and peroxynitrite in the lung during acute endotoxemia. $J$ Leukac Biol 56: 759-768, 1994.

29. Kamisaki $Y$, Wada K, Nakamoto $K$, Kishimoto $Y$, Kitano $M$, Itoh $T$. Sensitive determination of nitrotyrosine in human plasma by isocratic high-performance liquid chromatography. of Chromatography $B$ 685: 343-347, 1996.

30. Khan J, Brennan DM, Bradley N, Goa B, Bruckdorfer $R$, Jacobs M. 3-Nitrotyrosine in the proteins of human plasma determined by an ELISA method. Biochem J 330: 795-801, 1998.

31. Bouma MG, Laan MP, Denterner MA, Buurman WA. Analysis of soluble adhesion molecules. In A pracitcal approach Immunochemistry 2. Johnstone AP, Turnar MW, (Eds) Oxford University Press, Oxford pp. 181-196, 1997.

32. Engelberts 1, Möller A, Schoen GJM, Van der Linden CJ, Buurmann WA. Evaluation of measurement of human TNF in plasma by ELISA. Lymphokine Cytokine Res 10:69-76, 1991.

33. Secchi $C$, Berrini $A$, Borromeo $V$. An enzyme-linked immunosorbent assay for the determination of bovine prolactin in plasma. $J$ Immunol Methods 136: 1.7-22, 1991.

34. Martin BL, Wu D, Jakes $\mathrm{S}$, Graves DJ. Chemical influences on the specificity of ryrosine phasphorylation. J Biol Chem 265: 71.08-71 11, 1990.

35. Van der Vliet A, Smith D, ONeill CA, Kaur H, Darley-Usmar V, Cross CE, Halliwell B. Interactions of peroxynitrite with human plasma and its constituents: oxidative damage and antioxidant depletion. Biochem J 303: 295-301, 1994.

36. Ischiropoulos $H_{3}$ Al-Mehdi AD. Peroxynitrite-mediative protein modification. FEBS Letters 364 : $279-282,1995$.

37. Gow AJ, Duran D, Malcom $\mathrm{S}$, Ischiropoulos $\mathrm{H}$. Effects of peroxymitrite-induced protein modifications on tyrosine phosphorylation and degradation. FEBS Letfers 385: 63-66, 1996.

38. Halliwell $B$. What nitrates tyrosine ? Is nitrotyrosine specific as a biomarker of peroxynitrite formation in vivo? FEBS Letters 411: 157-160, 1997.

39. Eiserich JP, Cross CE, Jones AD, Halliwell B, Van der Vliet A. Formation of nitrating and chlorinating species by reaction of nitrite with hypoclorous acid. J Biol Chem 271: 19199-19208, 1996.

40. Van der Vliet A, Eiserich JP, Halliwell B, Cross CE. Fomation of reactive nitrogen species during peroxidase-catalyzed oxidation of nitrite. J Biol Chem 272: 761.7-7625, 1997.

41. Gunther MR, Hsi LC, Curtis JF, Gierse JK, Marnett LJ, Eling TE, Mason RP. Nitric oxide trapping of the tyrosyl radical prostaglandin $H$ synthase-2 leads to tyrosine iminoxyl radical and nitrotyrosine formation. J Biol Chem 272: 17086-17090, 1997.

42. Eiserich JP. Hristova M, Cross CE, Jones AD, Freeman BA, Halliwell B, Van der Vliet A. Formation of nitric oxide-derived inflammatory oxidants by myeloperoxidase in neutrophils. Nature 391: 393-397, 1998.

43. Van Stranten EA, Koster-Kamphuis L, Bovee-Oudenhoven IM, Van der Meer R, Forget PPL. Increased urinary nitric oxide oxidation products in children with active coeliac disease. Submitted to Acta Paediatr Scand.

44. Vallence P, Moncada S. Role of endogenous nitric oxide in septic shock. New Horizons 1: 77-86, 1993.

45. Ochoa JB, Udekwu AO, Billiar TR, Curran RD, Cerra FB, Simmons RL, Peitzman AB. Nitrogen oxide levels in patients after trauma and during septic shock. Ant Surg 214: 621-626, 1991.

46. Petros A. Bennett D, Vallence P. Effect of nitric oxide synthase inhibitors on hypotension in patients with septic shock, Lancet 338: 1557-1558, 1991. 


\section{CHAPTER 5}

PRESENCE OF INDUCIBLE NITRIC OXIDE SYNTHASE, NITROTYROSINE, CD68 AND CD14 IN THE SMALL INTESTINE IN COELIAC DISEASE

Ter Steege JCA, Buurman WA, Arends JW, Forget PPh.

Lab Invest 77: 29-36, 1997 


\section{ABSTRACT}

Coeliac disease is characterized by severe inflammation of the small intestine. Furthermore, inflammation is known to be often associated with enhanced nitric oxide (NO) production. The present study we aimed at investigating whether or not children with active coeliac disease show increased cluodenal inducible nitric oxide synthase (iNOS) expression by immunohistochemistry. Further, NO activity was assessed by detection of nitrotyrosine, which is an indicative marker for the formation of the No and superoxide-derived oxidant peroxynitrite. Serial staining with the macrophage markers CD68 and CD14 was performed to assess whether intestinal macrophages are involved in intestinal NO production. Duodenal biopsies from 7 children with normal biopsy findings were used for comparison. In ten out of 11 coeliac disease biopsies intense iNOS staining of enterocytes was observed whereas this was the case for only 1 out of 7 controls $(p<0.002)$. Also, nitrotyrosine staining was detected in the enterocytes of coeliac disease patients and was associated with iNOS staining. Further, the number iNOS-positive cells in the lamina propria was significantly $(p<0.002)$ enhanced in coeliac disease. Serial staining for iNOS, CD68 and CD14 revealed an increase in $\mathrm{CD} 68 / \mathrm{CD} 14$ double positive monocytes in coeliac disease, and colocalization of iNOS and CD14 expression. These data suggest that in patients with active coeliac disease iNOS is induced in the intestine and is associated with the formation of peroxynitrite and nitration of cellular proteins. Further, the increase in intestinal CD14-positive macrophages suggest a role for these cells in the pathophysiology of the disease.

\section{INTRODUCTION}

The small bowel of coeliac disease patients exhibits villous atrophy, crypt cell hyperplasia, lamina propria infiltration with lymphocytes, macrophages and plasma cells, and epithelial lymphocyte infiltration, all characteristic of severe inflammation $(1-4)$. There is increasing evidence that cell-mediated immunity is involved in the pathogenesis of coeliac disease (5). Infiltration of the epithelium by intraepithelial lymphocytes (IEL), particularly of the $\gamma \delta \mathrm{TCR}^{+}$phenotype, is the earlies! morphological feature of the coeliac lesion (6-9). An increase in these lymphocytes is also observed in the lamina propria $(8,10)$ and the periphery $(11)$. The precise function of these cells has still to be unraveled, however, Jones-Carson et al. (12) showed that the presence of TCR $\gamma \delta^{+}$lymphocytes in the intestine is essential for inducing NO synthesis by intestinal macrophages in a mouse model.

Another well-recognized feature of this enteropathy is an increase in the number of activated $\left(\mathrm{CD} 25^{+}\right) \mathrm{T}$ cells in the jejunal lamina propria, which are predominantly CD4 ${ }^{+}$TCR $\alpha \beta^{+}$(T helper) in origin, and whose major function is to secrete cytokines and to modulate immune responses (13-14). In line with this, elevated expression of 
mRNA for tumor necrosis factor- $\alpha$, interleukin- 6 and interleukin- 2 in the small intestine of untreated coeliac disease subjects has been reported (15). Still more characteristic for coeliac disease is the elevated production of interferon- $\gamma$ (IFN- $\gamma$ ) (16-17). The involvement of IFN- $\gamma$ in the pathophysiology of coeliac disease was demonstrated by Przemioslo et al. (18), who showed that IFN- $\gamma$ induced the intestinal injury characteristic for coeliac disease. Furthermore, the increase of epithelial permeability, an important feature of coeliac disease, induced by IFN- $\gamma$ has been shown to be NO mediated in in vitro studies (19-20).

A pilot study showed that urinary NO oxidation products are highly elevated in our pediatric patients with active coeliac disease (van Straaten, personal communications). These data and both the reported increase in the number of TCR $\gamma \delta$-positive lymphocytes as well as the enhanced IFN- $\gamma$ production -both characteristic features of coeliac disease- led us to hypothesize that the induction of elevated NO synthesis in the inflammatory lesions in the intestine of coeliac disease patients could play a role in the pathophysiology of the disease.

Inducible NOS (iNOS) is the enzyme responsible for NO production during inflammatory processes. The quiescent iNOS gene, mainly present in macrophages, is only activated in states of immune activation and inflammation, and can be detected by immunohistochemistry. Formation of peroxynitrite, a strong oxidizing agent that initiates lipid peroxidation, sulfhydry] oxidation of proteins and nitration of aromatic amino acids from NO and superoxide, might be the way through which NO induces tissue damage (21-23). A stable product of peroxynitrite oxidation is nitrotyrosine, which can be detected with immunohistochemistry (24-25). Thus, presence of nitrotyrosine is an indicator of the formation of peroxynitrite and its interaction with tyrosine residues in proteins.

In the present study, we investigated the putative cellular origin of NO production by staining small bowel biopsy tissue of active coeliac disease patients for iNOS and nitrotyrosine. Further, serial staining with the macrophage markers CD68 and CD14 was performed to assess whether intestinal macrophages are involved in NO production during intestinal inflammation.

\section{MATERIAL AND METHODS}

\section{Reagents}

Avidin-biotin-peroxidase $(\mathrm{ABC})$ kits were obtained from Vectastain (Vector Laboratories, Burlingame, CA). Aceton, methanol, hydrogen peroxidase and entellan were acquired from Merck (Darmstadt, FRG). Coated Starfrost object glasses were obtained from Klinipath (Duiven, the Netherlands). 3,3-diaminobenzidine was obtained from Serva (Heidelberg, FRG). Rabbit anti-human iNOS antiserum was kindly provided by Dr. I. Cohen, Royal Postgraduate Medical School (London, UK). 
The antibody to human iNOS was produced by immunizing rabbits with keyhole limpet hemocyanin conjugated to a synthetic peptide corresponding to amino acids 54 to 76 of the human iNOS sequence (26-28). Anti-iNOS activity was titrated by an ELISA using the peptide conjugated to BSA as the solid phase antigen. No cross reactivity to endothelial or neural NOS was observed (27). Further, it has been shown, by western blotting, that in crude homogenates of atherosclerotic aorta, the iNOS antiserum reacted with a band of approximately $130 \mathrm{kD}$ (the known molecular weight of iNOS), but no such band was seen in normal aorta (26). In addition, immunoreactivity in heart tissue of patients with dilated cardiomyopathy (28) and iNOS expression in the primary granules of stimulated neutrophils was observed using this antiserum (26). The anti-nitrotyrosine antibody $1 \mathrm{~A} 6\left(\mathrm{IgG}_{2}\right)$ was a kind gift of $\mathrm{Dr}$. J.S. Beckman, Department of Anesthesiology, UAB School of Medicine, Birmingham, AL. Mouse $\left(\mathrm{IgG}_{1}\right)$ anti-human macrophage marker $\mathrm{CD} 68$ was obtained from DAKO (Denmark). $3 \mathrm{C} 10$, a mouse anti-human $\mathrm{CD} 14$ antibody $\left(\operatorname{lgG}_{2 \mathrm{~b}}\right)$ was a kind gift from Dr. R. Steinmann, Rockefeller University (New York, NY). The nonspecific mouse antibody MOPC21 ( $\left.\operatorname{IgG}_{1}\right)$ was provided by Celltech (Slough, UK).

\section{Patients}

Biopsies of 11 coeliac disease patients ( 5 males and 6 females) were examined, and all showed subtotal villous atrophy on histo-pathological examination. Further, high titers of anti-gliadin and anti-endomysial were observed in all patients. The mean age of the patients was 5.2 years, with a range of 1.3 to 12.8 years. Six of these 11 children were newly diagnosed patients with active coeliac disease, while 5 patients were examined after a 3 month period of gluten challenge, containing approximately 4 gram of gluten each day. Duodenal biopsies of seven children with recurrent abdominal pain were used as control material. After intensive investigation, these children appeared to have normal duodenal histology and to be free of organic disease. This group consisted of 7 female patients, with a mean age of 6.9 years (range 2.1 to 13.1 years).

\section{Immunohistochemistry}

Frozen tissue sections $(5 \mu \mathrm{m})$ were cut, thaw-mounted onto coated glass slides, fixed in aceton for $10 \mathrm{~min}\left(-20^{\circ} \mathrm{C}\right)$ and air dried. Endogenous peroxidase was blocked by immersing the slides in $0.03 \%$ hydrogen peroxidase in methanol for $30 \mathrm{~min}$, followed by washing in PBS (three washes, 5 min each). After blocking nonspecific binding by incubation with $5 \% \mathrm{BSA}$ for $30 \mathrm{~min}$ and subsequent washing, sections were incubated for 1 hour with either rabbit anti-iNOS antiserum or with normal rabbit serum (negative control) diluted in PBS containing $0.1 \% \mathrm{BSA}$ and $2 \%$ normal human serum. Next, the sections were washed with PBS and incubated for 1 hour with biotinylated goat antiserum to rabbit $\operatorname{IgG}$ and subsequently incubated for $45 \mathrm{~min}$ with freshly prepared avidin-biotin-peroxidase. Peroxidase activity was detected using diamino- 
benzidine as substrate. Sections were counterstained with hematoxylin, dehydrated, and mounted in entellan. The same method was used to stain for nitrotyrosine, CD68, and CD14 except that a biotinylated goat anti-mouse antibody was used as second antibody. MOPC21 was used as negative control.

\section{Histological analysis}

The slides were scored blindly by two independent observers. iNOS and nitrotyrosine staining in the epithelium were scored on either presence (1) or absence (0). Three different values were given for the number of iNOS $^{+}$cells in the lamina propria: $0=$ not detectable, $1=0-10 \%$ iNOS $^{+}$cells, $2=>10 \%$ iNOS $^{*}$ cells. CD68 staining was scored as follows: $1=$ normal subepithelial $C D 68^{+}$band, $2=$ additional presence of $\mathrm{CD} 68^{+}$cells in the lamina propria. The scoring system used for the number of CD14 ${ }^{+}$ cells was as follows: $0=$ no $\mathrm{CD} 14^{+}$cells detected, $1=$ only a few $\mathrm{CD} 14^{+}$cells present, $2=$ clear presence of $\mathrm{CD} 14^{+}$cells. The results are presented as the mean score, median and range. The Mann-Whitney test was used to determine the statistical significance of differences found between coeliac patients and controls, $\mathrm{p}<0.05$ was considered statistically significant.

\section{RESULTS}

\section{iNOS immunohistochemistry}

All, except one, of the 11 biopsies from children with coeliac disease showed intense epithelial iNOS expression in the enterocytes of the crypts, villous enterocytes were not present in these patients as demonstrated by histo-pathological examination. No staining was observed when normal rabbit serum was used (negative control) instead of the iNOS antiserum. Other cells in the epithelium like Goblet cells and Paneth cells did not show iNOS expression. In the vast majority of these crypt enterocytes a supranuclear iNOS expression was observed. In contrast, in biopsy material of control children, only 1 out of 7 showed iNOS expression in enterocytes (Figure 1A and B, Table 1). However, in this biopsy, only about $60 \%$ of the enterocytes showed iNOS expression and the observed staining was more nuclear than supranuclear. Furthermore, low numbers of iNOS expressing cells $(<10 \%)$ were detected in the lamina propria of duodenal biopsy tissue of control children. These iNOS-positive cells showed a diffuse distribution throughout the lamina propria. Biopsy tissue of children with active coeliac disease showed a significant $(p<0.002)$ increase in the number of iNOS positive cells in the lamina propria in comparison with the controls (Figure $1 \mathrm{~A}$ and $\mathrm{B}$, Table 1). The iNOS-positive cells showed a macrophage like morphology, the staining did not colocalize with lymphoid cell aggregates but showed a tendency to be present in small groups of 2 to 4 cells frequently adjacent to blood 
vessels in the lamina propria. In general, iNOS staining was more intense in enterocytes as compared with the adjacent inflammatory cells in the lamina propria; the number of iNOS-positive cells was only a small fraction of the total inflammatory cell population.

Table 1. iNOS, CD68, CDI4 and nitrotyrosine staining of biopsy tissue in active coeliac disease and controls

\begin{tabular}{|c|c|c|c|}
\hline & $\begin{array}{l}\text { control } \\
\mathrm{n}=7\end{array}$ & $\begin{array}{l}\text { coeliac } \\
\mathrm{n}=11\end{array}$ & p. value ${ }^{s}$ \\
\hline DOS in epithelium & $1 / 7$ & $10 / 11$ & $<0.002$ \\
\hline nitrotyrosine in epithelium ${ }^{\text {t }}$ & $0 / 6$ & $5 / 6$ & $<0.015$ \\
\hline $\begin{array}{l}\text { ¿NOS in lamina propria: mean score" (median; } \\
\text { range) }\end{array}$ & $0.28(0 ; 0-1)$ & $1.4(2 ; 1-2)$ & $<0.002$ \\
\hline CD68 expression: mean score (median; range) & $1(1 ; 1)$ & $1.6(2 ; 1-2)$ & $<0.05$ \\
\hline CD14 expression: mean score ${ }^{\#}$ (median; range) & $0.17(0 ; 0-1)$ & $1.4(1 ; 1-2)$ & $<0.002$ \\
\hline
\end{tabular}

${ }^{\$}$ by Mann-Whitney

- $0=$ not detectable, $1=0-10 \%$ iNOS cells, $2 \Rightarrow 10 \%$ iNOS ${ }^{+}$cells

${ }^{+} 1=$ normal subepithelial $\mathrm{CD} 68^{+}$band, $2=$ clear presence of $\mathrm{CD} 68^{+}$cells in lamina propria additionally to the subepithelial band

" $0=$ no $C D 14^{*}$ cells, $1=$ a few $\mathrm{CD} 14^{+}$cells, $2=$ clear presence of $\mathrm{CD} 14^{+}$cells

"biopsy tissue of only 6 controls and 6 patients was available for nitrotyrosine staining

\section{Nitrotyrosine staining}

Nitrotyrosine was used as a marker for the presence of locally produced $\mathrm{NO}$ in intestinal tissue. As mentioned before, nitrotyrosine is a marker for the interaction between tissue proteins and peroxynitrite, the latter being a reaction product of NO and superoxide. Biopsy material of 6 patients and 6 controls was subjected to immunohistochemistry for nitrotyrosine. In control biopsy tissue, no nitrotyrosine staining could be detected. In contrast, positive staining for nitrotyrosine was observed in biopsy tissue of all, except 1, patients with active coeliac disease. Nitrotyrosine staining was observed mainly in the crypt enterocytes and in a few cells in the lamina propria. The staining in the enterocytes was supranuclear and colocalized with iNOS expression (Figure 1C and D, Table 1). The number of nitrotyrosine positive cells in the lamina propria was too small to draw conclusions on colocalization with iNOSpositive cells. 
Figure 1. Immunosiaining of iNOS $(A, B)$ and nitrotyrosine $(C, D)$ in nomal $(A, C)$ and coeliac disease (B,D) duodenal biopsy tissue. Note iNOS $(B)$ expression in enterocyes and lamina propria of dwodenal tissue in children with coeliac disease. An identical distribution is seen for witrotyrosine (D). Detection of CDI 4 expression in (E) control and $(F)$ coeliac disease biopsies. Norice the intense expression of $\mathrm{CDI} 4$ by macrophages scattered whough the lamina propria in coeliac disease (original magnification $400 x$ ).
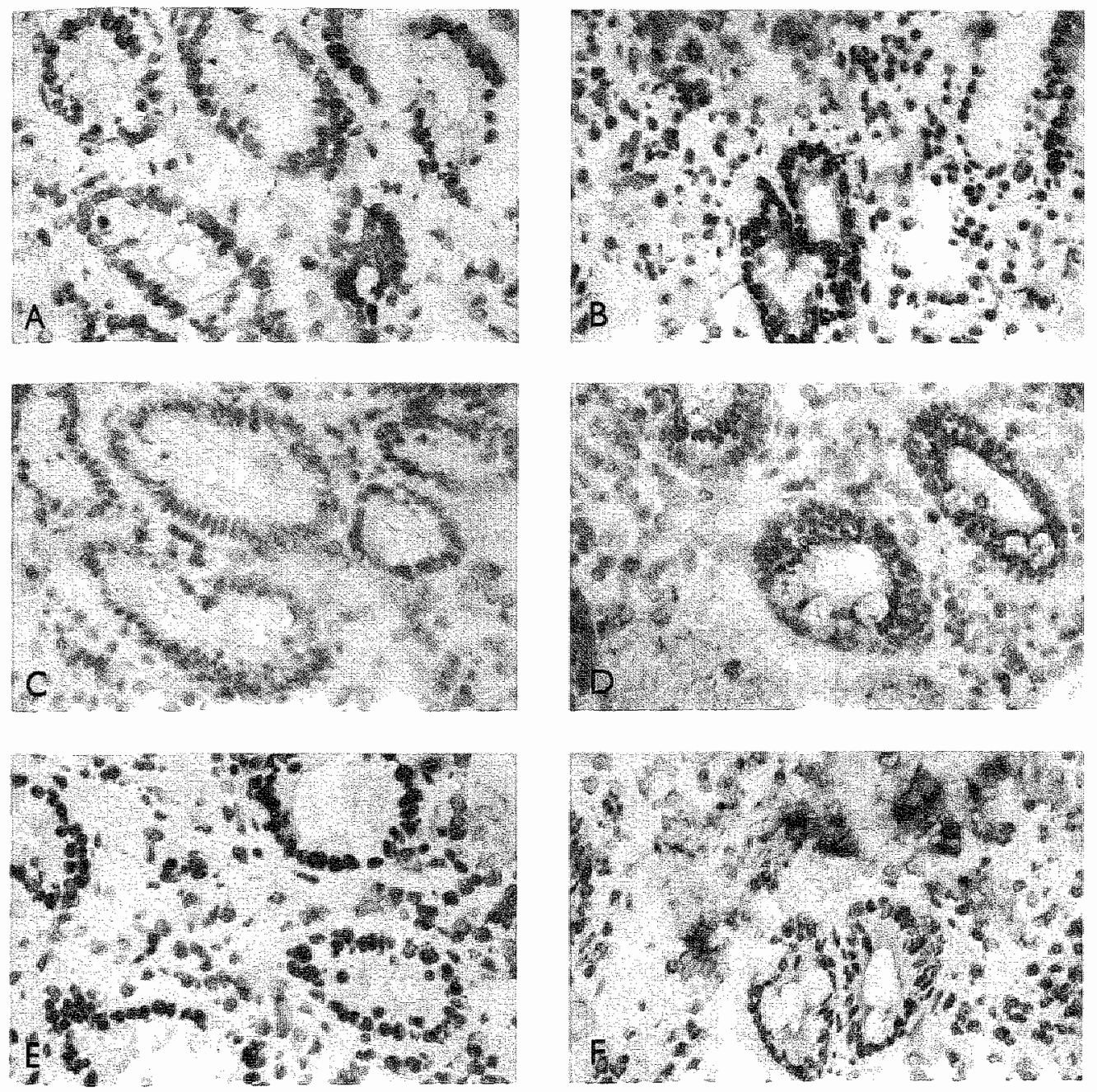


\section{CD68 and CD14 immunohistochemistry}

Since macrophages are known to be a major source of NO production through NOS in inflammation, we stained for the macrophage/monocyte marker CD68 to ascertain the monocytic nature of the iNOS-positive cells in the lamina propria. Immunohistochemical staining of uninflamed intestine in control subjects demonstrated a characteristic subepithelial band of $\mathrm{CD} 68^{+}$macrophages and a few CD68-positive cells dispersed through the lamina propria. Inflamed tissue of coeliac disease patients showed in addition to the subepithelial band of $\mathrm{CD} 68^{+}$macrophages an increased number of $\mathrm{CD} 68^{4}$ macrophages scattered throughout the lamina propria but mostly concentrated around the crypts. As the CD $68^{*}$ cells in the intestine by far outnumbered the iNOS-positive cells, no firm conclusion could be drawn about the nature of these iNOS-positive cells.

Normal residing intestinal macrophages do not express $\mathrm{CD14}$, whereas tissue infiltrating macrophages do. Since mucosal macrophage infiltration is characteristics of coeliac intestinal inflammation staining for CDI4 was performed to examine whether or not this macrophage subpopulation represents the lamina propria iNOSpositive cells. In controls, very low numbers of $\mathrm{CD} 14^{+}$cells scattered through the lamina propria were detected (Figure 1E). In contrast, $\mathrm{CD} 14^{+}$cells were present in elevated numbers in biopsies of coeliac disease patients (Figure 1F, Table 1) pointing to the presence of tissue infiltrating macrophages. These CD14 ${ }^{+}$cells were scattered throughout the lamina propria, but most of them were present in the subepithelial $\left(\mathrm{CD} 68^{*}\right)$ layer and frequently in small groups adjacent to blood vessels. Serial staining demonstrated some colocalization of $\mathrm{CD} 14^{+}$and iNOS-positive cells indicating that $\mathrm{CD} 14^{+}$cells also showed iNOS expression (Figure 1B and F).

\section{DISCUSSION}

The present study demonstrates enhanced iNOS expression in intestinal tissue, especially the epithelium, in patients with active coeliac disease in comparison with control subjects. The specificity of the antiserum used for the detection of iNOS expression is described elsewhere (26-28). In short, these studies demonstrated that the antiserum displayed no cross reaction with endothelial and neural NOS. Further, it has been shown, by western blot, that the iNOS antiserum strongly reacts with a specific $130 \mathrm{kD}$ band corresponding to the known molecular weight of iNOS.

As demonstrated by histo-pathological examination villous epithelium was not present in coeliac disease biopsy tissue, therefore enterocytic expression of inducible NOS was mainly observed in the crypt epithelium. In these biopsies, nitrotyrosine, the stable product of the action of peroxynitrite on tyrosine-containing proteins, was also locallized in the enterocytes, indicating that the iNOS enzyme detected is active. 
To explain the colocalization of iNOS and nitrotyrosine staining in the intestinal epithelium Singer et al. (29) suggested that NO produced by epithelial cells and superoxide produced by inflammatory cells, such as neutrophils and macrophages (27) in the lamina propria react within the epithelium to form peroxynitrite, which in turn, reacts with epithelial cell proteins to produce nitrotyrosine. It may, however, be questioned whether the lability of superoxide, originating from the lamina propria, will allow it to reach the epithelium to react with NO to form peroxynitrite. Therefore, an alternative hypothesis might be that the superoxide necessary for the formation of peroxynitrite is produced in the intestinal epithelium itself. Interestingly, Deitch et al. (30) reported recently that intestinal epithelial cells exert bactericidal activity through an oxidant-dependent pathway which is inhibited by superoxide dismutase, indicating that intestinal epithelial cells are capable of superoxide production.

Staining for iNOS and nitrotyrosine was, in contrary to the inflamed biopsy tissue of coeliac disease patients, not present in control biopsy tissue, which showed no histological evidence for inflammation. Thus, some element of the inflammatory response in coeliac disease, possibly IFN- $\gamma$, induces iNOS expression in duodenal enterocytes, leading to NO production which reacts with superoxide to produce peroxynitrite, subsequently forming nitrotyrosine and impairing cellular function. This suggestion is supported by data of Tepperman et al. (31) who showed that iNOS expression in epithelial cells was associated with diminished cell viability, suggesting that $\mathrm{NO}$, possibly via peroxynitrite formation, may lead to irreversible cellular injury. Moreover, evidence that peroxynitrite can destroy the gastrointestinal epithelium and induces severe colonic inflammation was provided by Rachmilewitz et al. (32).

The functional role of NO produced by epithelial iNOS in coeliac disease is unknown. Because the epithelial barrier is the front line of defence against luminal flora, it is conceivable that iNOS upregulation is initiated in these cells to establish a chemical barrier in order to limit bacterial translocation. Furthermore, there are also data that suggest that NO might diminish epithelial damage. Inhibition of NO synthesis has been shown to promote ethanol and LPS induced tissue damage, implying that $\mathrm{NO}$ also might have some protective effect when the intestine is injured (33-34). On the other hand, increased epithelial permeability is a well known biological effect of $\mathrm{NO}$, and is characteristic of coeliac disease. It might be speculated that the high amount of NO produced via iNOS is responsible for the injurious effects of NO whereas the small amounts of NO produced via the neural and constitutive NOS might have a protective effect in the intestine (35).

Our second finding is that, besides in the epithelium, the number of iNOS expressing cells in the lamina propria was also significantly increased in children with active coeliac disease, suggesting the presence of an active immune process in this mucosal compartment. Furthermore, staining for CD68 revealed an increase of CD68 ${ }^{+}$ macrophages in the lamina propria of coeliac disease patients. These data are in line with the earlier reported increase in macrophage infiltration in the lamina propria in coeliac disease (2-3). It is therefore conceivable that lamina propria macrophages 
express iNOS. However, no definite conclusion could be drawn concerning the nature of the iNOS-positive cells since serial staining for CD68 and iNOS showed that the CD6 $8^{+}$cells by far outnumber the iNOS-positive cells.

The presence of $\mathrm{CD} 14^{+}$as well as $\mathrm{CD} 14^{-}$macrophages in coeliac intestinal tissue demonstrates that in coeliac disease mucosal macrophages consist of two distinct populations. CD14 serves as the receptor for the Gram-negative bacterial cell wall product lipopolysaccharide (LPS) and the LPS binding protein (LBP) and renders cells sensitive to LPS stimulation (36-37). Macrophages residing in the intestine have been shown to be different from peripheral monocytes and tissue-infiltrating macrophages, since they are tolerant for LPS stimulation (38) because they lack the membrane antigen CD14 (39). The CD $14^{+}$macrophage subpopulation found in our patients with coeliac disease would therefore indicate that these macrophages represent infiltrating macrophages probably recently recruited from the circulation (39-40). The presence of lamina propria $\mathrm{CD} 14^{+}$cells that are susceptible to stimulation by LPS suggests a mechanism for the continuous inflammation in the coeliac diseased intestine. Because intestinal permeability is increased in coeliac disease, bacterial products can activate $\mathrm{CD} 14^{*}$ macrophages, resulting in increased production of $\mathrm{NNOS}$ as well as pro-inflammatory and chemotactic cytokines, such as interleukin-2, interleukin- 6 , and tumor necrosis factor- $\alpha$ (15). Colocalization of CDI 4 and iNOS positive cells, as observed in this study, is consistent with the hypothesis above. Although production of NO by iNOS in human monocytes/macrophages has been demonstrated (41), its potential role in human pathology remains controversial (42). Also, expression of iNOS in human macrophages appears to be differently regulated from that in rodents $(41,42)$. In addition, not all iNOS-positive cells in the lamina propria in the intestine of coeliac disease patients showed CD14 expression, indicating that other cell types, such as granulocytes, may also show iNOS expression.

While our data indicate that NO plays a role in intestinal inflammation there are several lines of evidence that support this. First, in ulcerative colitis iNOS expression has been detected in macrophages, granulocytes and crypt epithelial cells $(29,43)$. Further, increased intestinal levels of citrulline, a byproduct of NO formation from $\mathrm{L}$ arginine, have been reported in patients with ulcerative colitis and Crohn's disease (44-46). Furthermore, slightly elevated serum and urinary levels of nitrite/nitrate, the oxidation product of $\mathrm{NO}$ in these conditions have been demonstrated $(44,47)$. Interestingly, the increase in nitrite/nitrate concentrations in the urine of children with active coeliac disease was clearly higher than in inflammatory bowel disease, which might indicate that NO is produced in higher amounts in coeliac disease (van Straaten, personal communications; 44)

In conclusion, these results show that in children with active coeliac disease the intestinal mucosa is characterized by increased iNOS and nitrotyrosine expression mainly in epithelial cells. Further, an increase in iNOS expression was also obserwed in the expanded $\mathrm{CD} 68^{+}$and $\mathrm{CD} 14^{+}$macrophage population in the lamina propria. Increased understanding in the pathophysiology of coeliac disease would provide a 
better inside in the mechanism of development of food tolerance and intolerance in the intestine.

\section{Acknowledgment}

This work was supported by a grant (1996-20) from the Nutricia Research Foundation, The Hague, the Netherlands. Further, the authors thank Geertjan van Zonineveld for preperation of the pictures.

\section{REFERENCES}

1. Brandtzaeg P, Halstensen TS, Kett K, Krajc̈i P, Kvale D, Rognum TO, Scott H, Sollid LM. Immunobiology and inmunopathology of human gut mucosa: humoral immunity and intraepithelial lymphocytes. Gastroenterology 97: 1562 1584, 1989.

2. Marsh MN. Morphology and immunopathology of the jejunal lesion in gluten-sensitivity. Eur $J$ Gastroenterol Heparol 3: 108-114, 1992.

3. Marsh MN, Loft DE, Garner VG, Gordon DI. Time/dose response of coeliac mucosae to graded oral challenges with Frazer's fraction III of gliadin. Eur $J$ Gastroenterol Hepathol 4: 667-673, 1992.

4. Spencer I, Isaacson PG, Diss TC, MacDonald TT. Expression of disulfide-linked and nondisulfide-linked forms of the $T$ cell receptor $\gamma / \delta$ heterodimer in human intestinal intraepithelial Jymphocytes. Eur J Immunol 19: 1335-1338, 1989.

5. OFarrelly C, Gallagher RB. Intestinal gluten sensitivity: snapshots of an unusual autoimmune-like disease. Immunol Today 13: 474-476, 1992.

6. Halsiensen TS, Brandtzaeg P. Activated T lymphocytes in the celiac lesion: non-proliferative activation (CD25) of $\mathrm{CD} 4^{+} \alpha / \beta$ cells in the lamina propria but proliferation (Ki-67) of $\alpha / \beta$ and $\gamma / \delta$ cells in the epithelium. Eur J Immonol 23: 505-510, 1993.

7. Marsh MN. Mucosal pathology in gluten sensitivity. In, Celiac disease Marsh MN, (Ed.), Blackwell Scientific Publications, Oxford, pp. 136-191, 1996.

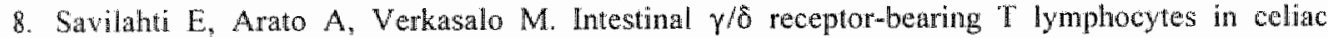
disease and indammatory bowel disease in children. Constant increase in celiac disease. Pedictr Res 28: 579-581, 1990 .

9. Spencer J, MacDonald TT, Diss TC, Walker-Smith JA, Ciclitira PJ, Isaacson PG. Changes in intraepithelial lymphocyte subpopulations in coeliac disease and enteropathy associated T cell lymphoma (malignant histiocytosis of the intestine). Gut 30: 339-346, 1989.

10. Russell GJ, Winter HS, Fox VL, Bhan AK. Lymphocytes bearing the yô T-cell receptor in nornal human intestine and celiac disease. Hum Pathol 22: 690-694, 1991.

11. Klemola T, Tarkkanen J, Örmälä T, Saxen H, Savilahti E. Peripheral $\gamma \delta \mathrm{T}$ cell receptor-bearing lymphocytes are increased in children with celiac disease. J Pediatr Gastr Nutr 18: 435-439, 1994.

12. Jones-Carson J, Vazquez-Torres A, van der Heyde HC, Wamer T, Wagner RD, Balish $\mathbb{E}$, $\gamma \delta$ T cell-induced nitric oxide production enhances resistance to mucosal candidiasis. Nature Med 1 : $552-557,1995$.

13. Maiuri L, Picarelli A, Boirivant M, Colletta S. Mazzilli MC, De Vincenzi M, Londei $M$, Auricchio. Definition of the initial immunologic modifications upon in vitro gliadin challenge in the small intestime of celiac patients. Gastroenterology 110:1368-1378, 1996. 


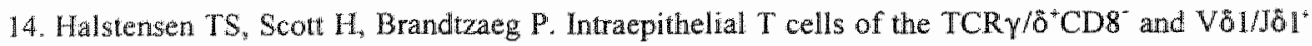
phenotypes are increased in coeliac disease. Scand I Immunol 30:665-672, 1989.

15. Kontakou M, Przemioslo RT, Sturgess RP, Limb AG, Ciclitira PJ. Expression of tumor necrosis factor- $\alpha$, interleukin-6, and interleukin-2 mRNA in the jejunum of patients with coeliac disease. Scand I Gastroenterol 30: 456-463, 1995.

16. Breese E., Kumar $P$, Farthing $M J$, MacDonald TT. Interleukin- 2 and interferon- $\gamma$ producing cells in the lamina propria in celiac disease. Dig Dis Sci 39: 2243, 1994.

17. Nilsen EM, Lundin KEA, Krajči P, Scott H, Sollid LM, Brandtzaeg P. Gluten specific, HLA-DQ restricted $T$ cells from coeliac mucosa produce cytokines with $T h 1$ or Tho profile dominated by interferon $\gamma$. Gut 37: 766-776, 1995 .

18. Przemioslo RT, Lundin KEA, Sollid LM, Nelufer $J$, Ciclitira PJ. Histological changes in small bowel mucosa indaced by gliadin sensitive T lymphocytes can be blocked by anti-interferon 1 antibody. Gut 36:874-879, 1995.

19. Kubes $\mathrm{P}$. Nitric oxide modulates epithelial permeability in the feline small intestine. Am $J P h y$ wol 262: G1138-G1142, 1995 .

20. Unno N, Menconi MI, Smith M, Fink MP. Nitric oxide mediates interferon- $\gamma$-induced hyperpermeability in cultured human intestinal epithelial monolayers. Crit Care Med 23: 1170$1176,1995$.

21. Beckman IS, Beckman TW, Chen J, Marshall PA, Freeman BA. Apparent hydroxyl radical production by peroxynitrite: Implications for endothelial injury from nitric oxide and superoxide. Proc Nat Acad Sci USA 87: 1620-1624, 1990.

22. Kubes $P$, Wallace $\int$. Nitric oxide as a mediator of gastrointestinal mucosal injury?-Say it ain't so. Med Inflamm 4: 397-405, 1995.

23. Radi R, Beckman JS, Bush KM, Freeman BA. Peroxynitrite oxidation of sulfhydryls. The cytotoxic potentiall of superoxide and nitric oxide. J Biol Chem 266:4244-4250, 1991.

24. Beckmann JS, Ye YZ, Anderson PG, Chen J, Accavitti MA, Tarpey MM, White CR. Extensive nitration of protein tyrosines in human atherosclerosis detected by inmunohistochemistry. Biol Chem 375: 81-88, 1994.

25. Miller MJS, Thompson JH, Zhang XJ, Sadowska-Krowicka H, Kakkis JL, Munshi UK, Sandoval M, Rossi JL, Eloby-Childress S, Beckman JS, Ye YZ, Rodi CP, Manning PT, Currie MG, Clark DA. Role of inducible nitric oxide synthase expression and peroxynitrite formation in guinea pig ileitis. Gastroenterology 109: 1475-1483, 1995.

26. Buittery LDK, Springdall OR, Chester AH, Evans TI, Standfield N, Parums DV, Yacoub MH, Polak JM. Inducible nitric oxide synthase is present within human atherosclerotic lesions and promotes the formation and activity of peroxynitrite. Lab lnvest 75: 77-85, 1996.

27. Evans TJ, Buttery LDK, Carpenter A, SpringdalI DR, Polak JM, Cohen J. Cytokine-treated human neutrophils contain inducible nitric oxide synthase that produces nitration of ingested bacteria. Proc Nort Acad Sci USA 93: 9553-9558, 1996.

28. Habib FM, Springdall DR, Davies GJ, Oakley CM, Yacoub MH, Polak JM. Tumor necrosis factor and induible nitric oxide synthase in dilated cardiomyopathy. Lancet 347: 1151-1154, 1996.

29. Singer 11, Kawka DW, Scott S, Weidner JR, Mumford RA, Riehl TE, Stenson WF. Expression of inducible nitric oxide synthase and nitrotyrosine in colonic epithelium in inflammatory bowel disease. Gastroenterology $\| 11: 871-885,1996$.

30. Deitch EA, Haskel Y, Cruz N, Xu D, Kvietys PR. Caco-2 and IEC-18 intestinal epithelial cells exert bactericidal activity through an oxidant-dependent pathway. Shock 4: 345-350, 1995.

31. Tepperman BL, Brown JF, Whittle BJR. Nitric oxide synthase induction and intestinal epithelial cell viability in rats. Am J Physiol 265: G214-G218, 1993.

32. Rachmilewilz D, Stamler IS, Bachwich D, Karmeli F, Ackerman Z, Podolsky DK. Enhanced colonic nitric oxide generation and nitric oxide synthase activity in ulcerative colitis and Crohn's disease. Gut 36: 718-723, 1995. 
33. Hutchenson $\mathbb{R}$, Whittle $\mathbb{B} J \mathbb{R}$, Bougthon-Smith $\mathrm{NK}$. Role of nitric oxide in maintaining vascular integrity in endotoxin-induced acute intestinal damage in the rat. Br J Pharmocol 101: $815-820$, 1990.

34. MacNaugthon WK, Cirino G, Wallace JL. Endothelium-derived relaxing factor (nitric oxide) has protective actions in the stomach. Life Sci 4589: 1869-1876, 1989.

35. Nussler AK, and Billiar TR (1993). Inflammation, immunoragulation, and inducible nitric oxide synthase. J Leukoc Biol 54:171-178

36. Schumann RR, Leong SR, Flaggs GW, Gray PW, Wright SD, Mathison JC, Tobias PS, Ulevitch RU. Structure and function of lipopolysaccharide binding protein. Science 249: 1429-1431, 1990 .

37. Wright SD, Ramos RA, Tobias PS, Ulevitch RJ, Mathison JC. CD14, a receptor for complexes of lipopolysaccharide (LPS) and LPS binding protein. Science 249: 1431-1433, 1990.

38. Stephens RW, Golder JP, Fayle DRH, Hume DA, Hapel AJ, Allan W, Fordham CJ, Doe WF. Minactivin expression in human monocyte and macrophage populations. Blood 66: 333-337, 1985.

39. Grimm MC, Pavli P, Van De Pol E, Doe WF. Evidence for a CD14 population of monocytes in inflammatory bowel disease mucosa-implications for pathogenesis. Clin Exp Immunol 100: 291$297,1995$.

40. Grimm MC, Pullman WE, Bennett GM, Sullivan PJ, Palvi P, Doe WF. Direct evidence of monocyte recruitment to inflammatory bowel disease mucosa. J Gastroenterol Hepatol 10: $387-$ $395,1995$.

41. Dugas B, Mossalayi MD, Damais C, Kolb JP. Nitric oxide production by human monocytes: evidence for a role of CD23. Immunol Today 12:574-580, 1995.

Albina JE. On the expression of nitric oxide synthase by human macrophages. Why no NO? I Leukocyle Biol 58: 643-649, 1995.

43. Mourelle M, Casellas F, Guarner F, Salas A, Riveros-Moreno V, Moncada S, Malagelada JR. Induction of nitric oxide synthase in colonic smooth muscle from patients with toxic megacolon. Gastroenterology 109: 1497-1502, 1995.

44. Melichar B, Karliček $R$, Tichy $M$. Increased urinary nitrate excretion in inflammatory bowel disease. Eur J Clin Chem Clin Biochem 32: 3-4, 1994.

45. Middleton SJ, Shorthouse M, Hunter JO. Increased nitric oxide synthesis in ulcerative colitis. Lancet 341: 465-466, 1993.

46. Rachmilewitz D, Stamler JS, Karmeli F, Mullins ME, Singel DJ, Loscalzo J, Xavier RJ, Podolsky DK. Peroxymitrite-induced rat colitis - A new model of colonic inflammation. Gastroenteroiogy $105: 1681-1688,1993$.

47. Oudekerk Pool M, Bouma G, Visser Jd, Kolkman JJ, Tran DD, Meuwissen SGM, Peña AS. Serum nitrate levels in ulcerative colitis and Crohn's disease. Scand J Gastroenterol 30: 784-788, 1995. 
$-108-$ 


\section{CHAPTER 6}

THE ROLE OF ENDOGENOUS IFN- $\gamma$, TNF- $\alpha$ and IL- 10 IN LPS-INDUCED NITRIC OXIDE RELEASE IN A MOUSE MODEL

Ter Steege JCA, Van de Ven WCM, Forget PPh, Brouckaert P, Burman WA. Cytokine 10:115-123,1998 


\section{ABSTRACT}

Mice injected with lipopolysaccharide develop lethal septic shock, accompanied by elevated serum $\mathrm{NO}_{x}, \mathrm{IFN}-\gamma, \mathrm{TNF}-\alpha$ and TNF-receptor levels. Elevated NO levels are thought to play a central role in tissue damage observed during septic shock. In witro data indicate that IFN- $\gamma$ and TNF $\alpha$ play an important role in LPS-induced NO release. Further, IL-10 has been shown to inhibit the release of pro-inflammatory cytokines such as IFN- $\gamma$ and TNF- $\alpha$. Therefore, in the present study, we investigated the role of IFN- $\gamma$, TNF $-\alpha$, and IL-10 in LPS-induced NO release. To this end, mice were pretreated with anti-IFN- $\gamma$, anti-TNF $\alpha$, anti-IL-10 mAbs or combinations there of two hours before LPS-challenge. Our results indicate that IFN- $\gamma$, TNF- $\alpha$ as well as IL-10 are involved in the regulation of LPS-induced NO release. Blocking either IFN- $\gamma$ or TNF- $\alpha$ has no effect on LPS-induced NO release, however, blocking both IFN- $\gamma$ and TNF- $\alpha$ nearly completely prevents NO release after LPS challenge, suggesting that the presence of either TNF $-\alpha$ or IFN- $\gamma$ is essential for induction of NO release after LPS challenge. Further, our results obtained with anti-IL-10 treatment suggest the presence of an IL-10 inducible factor which together with IFN- $\gamma$ and TNF- $\alpha$ regulates $L P S-i n d u c e d ~ N O$ release.

\section{INTRODUCTION}

Injection of lipopolysaccharide (LPS) in rodents induces a sigmificant increase in serum nitrite and nitrate $\left(\mathrm{NO}_{\mathrm{X}}\right.$ ) levels, indicating elevated production of nitric oxide (NO). Inducible nitric oxide synthase (iNOS) is the enzyme responsible for the enthanced NO production during inflammation (1). Although increased NO synthesis during experimental endotoxemia has been shown to have beneficial effects, high concentrations of NO can also have deleterious effects (1-5). Therefore, the production of NO needs to be tightly regulated. Pro-inflammatory cytokines, such as interferon-gamma (IFN- $\gamma$ ) and tumor necrosis factor- $\alpha$ (TNF- $\alpha$ ), released during endotoxemia are likely to be involved in the regulation of $\mathrm{NO}$ production since in vitro data show that these cytokines play an important role in the upregulation of $\mathrm{NO}$ synthesis (6-8). Further, anti-inflammatory cytokines such as interleukin-10 (IL-10) and interleukin-4 (IL-4), also released during endotoxemia, may be involved in the downregulation of $\mathrm{NO}$ production (9).

In wiro results have demonstrated that the Th1-derived cytokine IFN- $\gamma$ regulates the LPS-induced NO release $(6,10)$. The presence of IFN- $\gamma$ is essential for production and release of NO by most macrophage-like cells after LPS challenge (11). Furthermore, the NO inducing effect of interleukin- 12 has been shown to be fully mediated by IFN- $\gamma$ production (12). In addition, TNF- $\alpha$ has been demonstrated to be a mediator of induction of NO synthesis in vitro since anti-TNF- $\alpha$ antibody treatment reduced the LPS-induced NO release by a murine macrophage cell line $(7,13)$. 
Others, however, have reported that murine macrophage NO production is not inhibited by anti-TNF- $\alpha$ antibody treatment (13-14).

The anti-inflammatory Th2-derived cytokine IL-10 was shown to inhibit NO production by activated macrophages. Recent data indicate that $I L-10$ might inhibit macrophage function directly and thereby suppress NO production in these cells (15). This inhibition, however, could also be an indirect effect of IL-10, mediated through inhibition of release IFN- $\gamma$ and/or TNF- $\alpha$ which are both potent macrophage activators (15-16). In line with these observations, treatment with anti-IL-10 has been shown to enhance NO and TNF- $\alpha$ production $(15,17)$. Furthermore, IL-10 is known to increase serum levels of soluble TNF-receptors (sTNFRs) which neutralize circulating TNF- $\alpha$ (18-19). In addition, IL-4, another Th2 cytokine, is involved in the downregulation of $\mathrm{NO}$ synthesis in vitro as well as in vivo (9-1-, 20-21).

Taken together, evidence exists that IFN- $\gamma$, TNF- $\alpha$ and IL-10 are involved in the regulation of NO production in vitro, but their role in the early regulation of NO release after LPS challenge in vivo has not yet been elucidated. Therefore, in the present study we investigated the role of endogenous IFN- $\gamma$, TNF- $\alpha$ and $1 \mathrm{~L}-10$ as proximal mediators in LPS-induced NO release in a mouse model. Two hours before LPS injection mice were treated with anti-IFN- $\gamma$ monoclonal antibody (mAb), antiTNF- $\alpha$ mAb, anti-IL- $10 \mathrm{mAb}$, or a combination thereof. The effects of these interventions on serum $\mathrm{NO}_{\mathrm{x}}$ levels 6 hours after LPS challenge were determined. As control on mAb pretreatment, systemic levels of IFN- $\gamma$, TNF- $\alpha$, sTNFRs, and interleukin-6 (IL-6) were evaluated in parallel.

\section{MATERIALS AND METHODS}

\section{Reagents}

Lipopolysaccharide (LPS) E.coli OB55:B5, 3-[4,5-dimethylthiazol-2-yl]-2,5 diphenyltetrazolium bromide (MTT) and bovine serum albumin (BSA) were obtained from Sigma (St Louis, MO); sulphuric acid was obtained from Merck (Darmstadt, FRG). 3,3',5,5'-tetramethylbenzidine (TMB) was from Kirkegaard \& Perry Laboratories Inc. (Gaithersburg, MD). NADPH and nitrate reductase were obtained from Boehringer Mannheim (Mannheim, FRG). Polyclonal rabbit anti-murine TNF antibodies (RaMT) were produced by injecting rabbits with murine TNF. Polyclonal rabbit anti-murine TNF-R55 and rabbit anti-murine TNF-R75 antibodies were raised by immunizing rabbits with the soluble extracellular domain of the corresponding receptors, kindly provided by Prof. W. Fiers (Laboratory of Molecular Biology, University of Gent, Gent, Belgium) and Prof. M. Feldman (Kennedy Institute of Rheumatology, London, UK) respectively.

The following agents were obtained through the courtesy of the respective companies or persons: Chimeric TN 319.12 is a CDR-grafted antibody of hamster 
origin of murine $\mathrm{IgGl}$ isotype specific for murine TNF by Celltech (Slough, UK); recombinant murine TNF by BASF/Knoll (Ludwigshafen, FRG); Anti-murine IFN-y (F3) by Dr. H. Heremans (Rega Institute, Leuven, Belgium); anti murine IL-10 (JES52A5) and the mouse IFN- $\gamma$ elisa kit by Hbt (Uden, the Netherlands).

\section{Animals}

Female Swiss mice (2-6 months) were obtained from Charles River Breeding Laboratories (Heidelberg, FRG), maintained on standard laboratory diet and allowed free access to water. Guidelines of the Committee for Care and Use of Laboratory Animals from the University of Limburg were followed throughout.

TNF-R55 knock out mice and their original strain were obtained from Dr. $\mathrm{H}$. Bluethmann (22) (Hoffman La Roche, Basel, Switzerland), TNF-R75 knock out mice and their original strain were from Dr. M. Moore (23) (Genentech Inc., South San Francisco, CA) and the TNF/LT- $\alpha$ knock out mice were from Dr. H.P. Eugster (24) (University Hospital Zurich, Dept. of Internal Medicine, Zurich, Switzerland). These mice were bred at the Laboratory of Molecular Biology, University of Gent (Gent, Belgium) according to Belgian and European Union guidelines for the use and care of laboratory animals.

\section{Experimental protocol}

LPS ( $250 \mu \mathrm{g}$ in $0.5 \mathrm{ml}$ PBS) was given by i.p. injection to mice. Two hours before LPS injection the mice were treated by i.p. injection with either $0.5 \mathrm{ml}$ PBS (LPS control group, $n=10$ ), $100 \mu \mathrm{g} \mathrm{F} 3$ (anti-IFN- $\gamma, \mathrm{n}=10$ ) in $0.5 \mathrm{ml}$ PBS, $750 \mu \mathrm{g}$ TN3 (antiTNF- $\alpha, n=10$ ) in $0.5 \mathrm{ml} \mathrm{PBS}, 1 \mathrm{mg}$ JES-2A5 (anti-IL-10, $\mathrm{n}=10$ ) in $0.5 \mathrm{ml}$ PBS or a combination of these antibodies $(n=5)$ at the same concentration and endvolume $(0.5$ $\mathrm{ml}$ ). The results were compared with a non-treated control group which received two times $0.5 \mathrm{ml}$ PBS. Six hours after LPS injection, blood was sampled by orbital punction after which the mice were sacrificed by cervical dislocation.

\section{Serum $\mathrm{NO}_{\mathrm{x}}$ (nitrite and nitrate) levels}

Nitrite and nitrate $\left(\mathrm{NO}_{\mathrm{X}}\right)$ levels, indicators of $\mathrm{NO}$ synthesis were measured in serum, after reducing nitrate to nitrite with bacterial nitrate reductase, using a microplate assay method, based on the Griess reaction (25). In short, $30 \mu 1$ serum, $10 \mu 1$ NADPH $(0.75 \mathrm{U} / \mathrm{ml})$ and $10 \mu \mathrm{l}$ nitrate reductase $(0.5 \mathrm{U} / \mathrm{mll})$ were incubated in a 96-well microplates for $20 \mathrm{~min}$ at room temperature (RT) after which $50 \mu \mathrm{l}$ Griess reagents, which consists of 1 part $0.1 \% N$-(1-naphthyl)-ethylenediamine dihydrochloride in distilled water and 1 part $1 \%$ sulfanilamide in $5 \%$ concentrated $\mathrm{H}_{3} \mathrm{PO}_{4}$, was added and incubated for $10 \mathrm{~min}$ at RT. The absorbance at $540 \mathrm{~nm}$ was determined using a 
microwell plate reader. The amount of nitrite was calculated from a $\mathrm{NaNO}_{2}$ standard curve prepared in serum.

\section{Enzyme linked immunosorbent assay (ELISA) for murine TNF}

Elisa for murine TNF was performed as described earlier by Dentener et al. (26). A hamster anti-murine monoclonal (TN3) was used as capture antibody and a polyclonal rabbit anti-murine TNF as secondary antibody. The elisa has a lower detection limit of $50 \mathrm{pg} / \mathrm{ml}$.

\section{WEHI 164 cytotoxicity bioassay}

Biologic TNF activity was measured using the murine fibrosarcoma WEHI 164 cell line (27-28). The MTT-method was used to assess cell killing as described previously (29). A standard titration curve was obtained by making serial dilutions of a known quantity of a murine rTNF sample. The dilution giving rise to $50 \%$ lysis was correlated with the $\mathrm{LD}_{50}$ of the standard curve. This method was used for determination of TNF- $\alpha$ serum levels in all anti-TNF- $\alpha$ treated animal because TN3 used as the anti-TNF- $\alpha$ treatment interferes in the TNF- $\alpha$ elisa.

\section{ELISA for murine TNF-Receptors}

ELISA for murine sTNF-Rs was performed as described earlier by Bemelmans et al. (18) A rabbit anti-soluble murine TNF-R55 or rabbit anti-soluble murine TNF-R75, was used as capture antibody. Serum samples $(50 \mu l)$ were diluted ten times and correlated to a standard titration curve of recombinant murine TNF-R55 or TNF-R75, respectively. A biotinylated polyclonal rabbit anti-soluble mTNF-R55 or anti-soluble mTNF-R75 was used as secondary antibody. A streptavidin peroxidase conjugate incubation was followed by TMB. The reaction was stopped with $1 \mathrm{M} \mathrm{H}_{2} \mathrm{SO}_{4}$. Optical density was read by $450 \mathrm{~nm}$. The detection limit for murine STNF-R55 was $5 \mathrm{pg} / \mathrm{m}$ l and for murine sTNF-R75 $50 \mathrm{pg} / \mathrm{ml}$.

\section{Bioassay for IL-6}

Serum IL-6 was measured by bioassay using an IL-6 dependent B9 hybridoma cellline (30) (a generous gift of Dr. L. Aarden, CLB, Amsterdam, the Netherlands) and proliferative activity was estimated using the MTT method (29). 


\section{Statistical analysis}

The Mann-Whitney test was used to determine the statistical significance of difference found between the various groups. Differences showing a $p<0.05$ were considered statistically significant.

\section{RESULTS}

\section{Effect of anti-IFN $\gamma$ on LPS-induced serum $\mathrm{NO}_{x}$ levels}

Initial experiments revealed significantly elevated concentrations of serum $\mathrm{NO}_{X}$ in mice 6 hours after LPS injection. Further, serum levels of IFN- $\gamma$, TNF- $\alpha$, sTNF-Rs and IL-6 were also increased (Table 1).

Table 1. Serum NO, IFN- $\gamma$, TNF- $\alpha$, sTNFRs and IL-6 levels in animals treated with $250 \mathrm{\mu g}$ LPS are significantly elevated 6 hours after LPS challenge in comparison with untreated mice.

\begin{tabular}{llll} 
serum levels & untreated & LPS-treated & p value \\
\hline $\mathrm{NO}_{\mathrm{x}}(\mu \mathrm{M})$ & $16.9 \pm 13.6$ & $108.2 \pm 59.1$ & $<0.0001$ \\
$\mathrm{IFN}-\gamma(\mathrm{ng} / \mathrm{ml})$ & $1.6 \pm 0.8$ & $7.8 \pm 7.2$ & $<0.005$ \\
$\mathrm{TNF}-\alpha(\mathrm{ng} / \mathrm{ml})$ & $\mathrm{ND}^{*}$ & $1.6 \pm 0.9$ & $<0.0001$ \\
$\operatorname{sTNF}-\mathrm{R} 55(\mathrm{ng} / \mathrm{ml})$ & $0.9 \pm 0.6$ & $1.5 \pm 0.9$ & $<0.05$ \\
$\mathrm{sTNF}-\mathrm{R} 75(\mathrm{ng} / \mathrm{ml})$ & $19.5 \pm 18.7$ & $77.6 \pm 21.9$ & $<0.0001$ \\
$\mathrm{IL}-6(\mathrm{ng} / \mathrm{ml})$ & $\mathrm{ND}^{*}$ & $33.6 \pm 25.5$ & $<0.001$ \\
\hline
\end{tabular}

Data are expressed as mean $\pm \mathrm{SD}(\mathrm{N}=10)$. The Mann-Whitney test was used to determine statistical significance between the LPS and non-treated group. Differences showing a $\mathrm{p}<0.05$ were considered statistically significant. *ND: not detectable.

The role of IFN- $\gamma$ in the induction of LPS-induced NO release was investigated by pretreatment with MAb F3 (anti-IFN- $\gamma$ ). Anti-IFN- $\gamma$ treatment did not significantly affect serum $\mathrm{NO}_{\mathrm{x}}$ levels after LPS challenge (Figure 1A), suggesting that LPSinduced NO release is not exclusively dependent on an IFN- $\gamma$ mediated pathway. The efficacy of $\mathrm{mAb} \mathrm{F3}$ was confirmed by measuring serum IFN- $\gamma$, TNF- $\alpha$ and sTNFRs. 
IFN- $\gamma$ could only be detected in one out of ten mice (Figure 1B), whereas no effect of anti-IFN- $\gamma$ was observed on serum TNF- $\alpha$ (Figure 1C) and sTNF-R concentrations (Figure 2). These data suggest that anti-IFN- $\gamma$ treatment was effective.

Figure 1. Pretreatment with either anti-IFN-y or anti-TNF-a does not affect LPS (250 $\mu \mathrm{g})$ induced seram $N O_{x}$ levels after 6 hours whereas combined pretreatment with anti-IFN- $\gamma$ and anti-TNF- $\alpha$ inhibits LPS-induced levels of serum $N O_{X}$ almost completely (A). Serum IFN- $\gamma$ (B) and TNF- $\alpha$ (C) levels were undetectable in the pretreated animals. Data are expressed as mean percentage of LPS-control values $\pm S D$. For normal and LPS-induced serum NO ${ }_{x}$ IFN$\gamma$ and TNF- $\alpha$ levels see Table 1. 1: LPS-control group $(n=10) ; 2$ : anti-IFN- $\gamma+L P S(n=10) ; 3$ : anti-TNF- $\alpha+L P S(n=10) ; 4$ : anti-IFN- $\gamma+$ anti-TNF- $\alpha+L P S(n=5) . * ;<<0.05$ as compared with LPS control group; ND: not derectable.
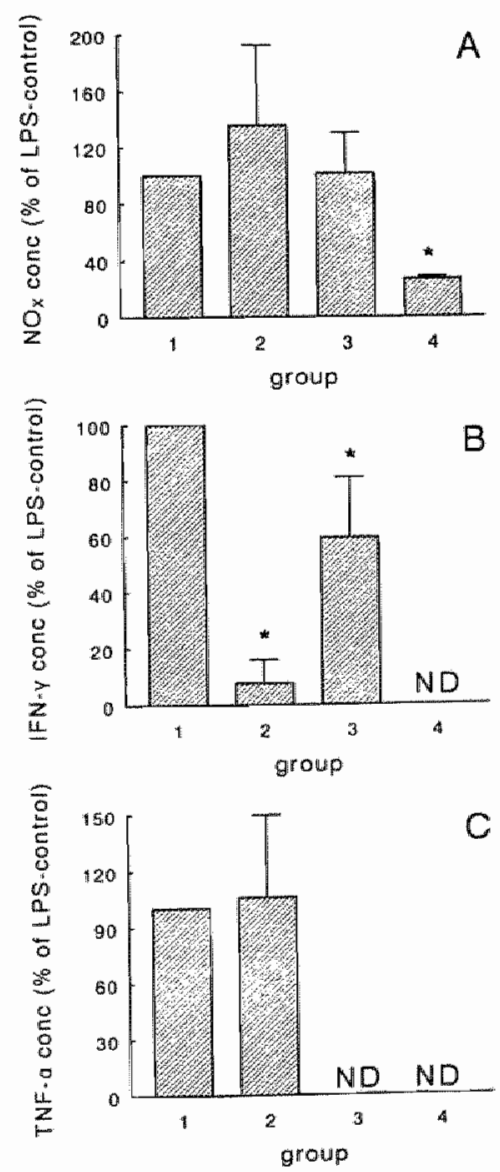


\section{Effect of anti-TNF- $\alpha$ on LPS-induced serum $\mathrm{NO}_{\mathrm{X}}$ levels}

Next, we investigated the role of TNF- $\alpha$ in LPS-induced NO release. Pretreatmem with mAb TN3 (anti-TNF- $\alpha$ ) did not significantly influence serum $N O_{x}$ levels; suggesting that $\mathrm{NO}$ release induced after LPS challenge is not solely mediated through increased TNF- $\alpha$ levels (Figure 1A). To confirm the effectiveness of the anti-TNF - . treatment, serum TNF- $\alpha$, IFN- $\gamma$, sTNF-R and IL-6 levels were determined in parallel. As expected, using a bioassay for TNF- $\alpha$, bioactive TNF- $\alpha$ was not detectable in serum of these mice (Figure 1C). Further, IFN- $\gamma$ levels were significantly inhibited as compared to the LPS-control animals (Figure IB). Inactivation of TNF- $\alpha$ in the circulation led to a small, statistically non-significant increase in levels of both sTNFRs (Figure 2). In order to further confirm the effectiveness of the anti-TNF- $\alpha$ pretreatment serum IL-6 levels were determined. Anti-TNF- $\alpha$ pretreatment reduced serum IL-6 concentrations in these mice in comparison with LPS-control mice (data not shown), indeed supporting the efficacy of the anti-TNF- $\alpha$ treatment (21).

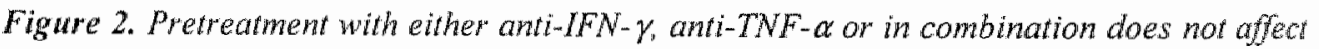
LPS-induced senm levels of STNF-R75 (A) and STNF-RS5 (B), 6 hours affer LPS (250 $\mu \mathrm{g})$ challenge by pretreatment with either anti-IFN- $\gamma$, anti-TNF- $\alpha$ or in combination. Data are expressed as mean percentage of LPS-control values \pm SD. For normal and LPS-induced serum STNFR levels see Table 1. 1: LPS-control group $(n=10) ; 2$ : anti-IFN- $\gamma+L P S(n=10)$; 3: anti-TNF- $\alpha+L P S(n=10) ; 4:$ anti-IFN- $\gamma+a n t i-T N F-\alpha+L P S(n=5)$.
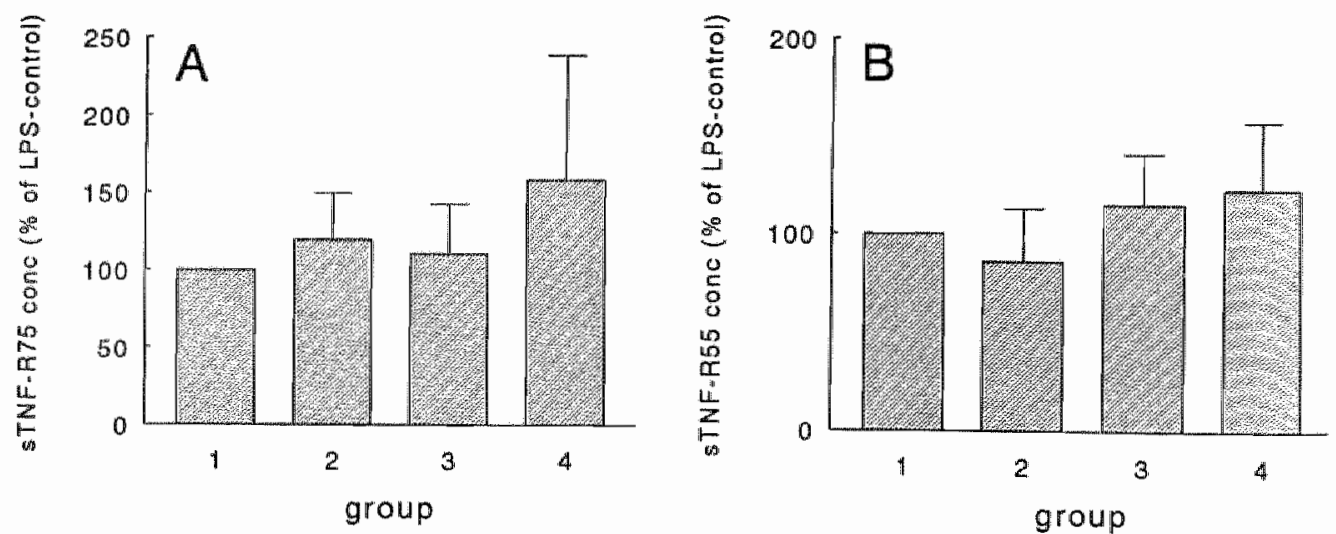

Taken together, these data indicate that LPS-induced NO release is not exclusively dependent on a TNF $\alpha$ mediated pathway. To further confirm that absence of circulatory TNF- $\alpha$ does not affect $\mathrm{NO}$ release after LPS challenge in vivo, we administrated LPS to TNF, TNF-R55 and TNF-R75 knock-out mice and their wild 
type strains, and determined serum $\mathrm{NO}_{\mathrm{x}}$ levels. The knock-out mice showed similar elevations of serum $\mathrm{NO}_{\mathrm{x}}$ levels 6 hour after LPS injection as compared to their wild type strains (Figure 3), supporting our conclusion that LPS-induced NO release in wivo is not solely mediated through enhanced TNF- $\alpha$ levels.

Figure 3. LPS $(250 \mu \mathrm{\mu g})$ induces elevated serum NO levels in TNF knock out, TNF-R55 and TNF-R75 knock mice (B) similar to what occurs in the wild type strains (A) 6 hours after challenge. Data are expressed as mean values $\pm S D$. Each group consisted of 5 mice. $1:$ TNF$R 55+/+$ and $-/ 2: T N F-R 75+/+$ and $\% ; 3: T N F+/+$ and $-/-$ mice.
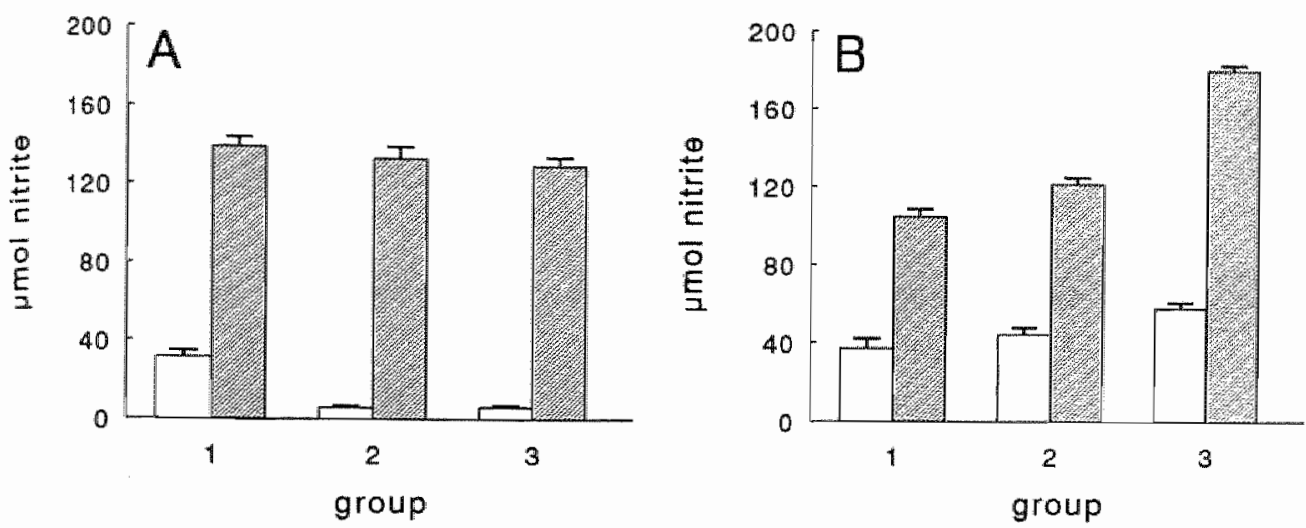

Effect of combined treatment with anti-IFN- $\gamma$ and anti-TNF- $\alpha$ mAbs on LPSinduced serum $\mathrm{NO}_{\mathrm{X}}$ levels.

To further elucidate the role of endogenous IFN- $\gamma$ and TNF- $\alpha$ in NO release after LPS challenge, mice were treated with anti-IFN- $\gamma$ and anti-TNF- $\alpha$ simultaneously 2 hours before LPS injection. As compared to LPS-control animals combined treatment with anti-IFN- $\gamma$ and anti-TNF- $\alpha$ nearly completely prevented LPS-induced NO release (Figure 1A). Taken together, these observations show that LPS-induced NO release is mediated by at least two pathways comprising either IFN- $\gamma$ or TNF- $\alpha$. Blocking either the IFN $-\gamma$ or TNF- $\alpha$ NO inducing pathway has no effect on NO release 6 hours after LPS challenge. However, blocking both the IFN- $\gamma$ and TNF- $\alpha$ pathway nearly completely inhibits LPS-induced NO release, indicating that the presence of elevated levels of either IFN- $\gamma$ or TNF- $\alpha$ is essential for the induction of NO release after LPS challenge. Further, serum levels of IFN- $\gamma$ and TNF- $\alpha$ were undetectable in these mice (Figure $1 \mathrm{~B}$ and $\mathrm{C}$ ) and no significant effect of this combined treatment on serum levels of both sTNFRs was observed (Figure 2). 


\section{Effect of anti-M-10 on LPS-induced serum $\mathrm{NO}_{x}$ levels}

The role of the anti-inflammatory cytokine $\mathrm{IL}-10$ in the induction of NO release after LPS challenge was investigated using mAb JES-2A5 (anti-IL-10). Pretreatment with anti-IL-10 induced a two-fold increase in LPS-induced serum $\mathrm{NO}_{\mathrm{x}}$ levels (Figure 4A). Further, serum IFN- $\gamma$, TNF- $\alpha$, sTNF-R and IL-6 levels were changed as well. IFN-y levels showed a five-fold increase in comparison with LPS-control animals (Figure 4B). Most striking were the seventeen-fold increase in $\mathrm{IL}-6$ from $33.64 \pm 25.46$ to 581 $\pm 214 \mathrm{ng} / \mathrm{ml}$ and the approximately thirty-fold increase in serum TNF- $\alpha$ levels (Figure $4 C$ ). In line with earlier data (19), anti-IL-10 pretreatment inhibited the LPS-induced increase in concentrations of both sTNFRs. Soluble TNF-R55 levels decreased nonsignificantly to $74.2 \pm 21.1 \%$ of LPS-control values and sTNF-R75 levels decreased significantly to $74.2 \pm 10.2 \%$ of LPS-control values (Figure 5). Together, these results demonstrate that endogenous $I L-10$ is involved in the regulation of $N O, \mathbb{L}-6$, IFN $-\gamma$, TNF $-\alpha$ and sTNFR release after LPS challenge.

\section{Effect of combined treatment with anti-IL-10 and anti-IFN- $\gamma$ or anti-IL-10 and anti-TNF- $\alpha$ on LPS induced serum $\mathrm{NO}_{\mathrm{x}}$ levels}

While a direct inhibitory effect of IL-10 on NO synthesis could be hypothesized, alternatively it is conceivable that IL-10 might indirectly inhibits NO release by suppressing the release of IFN- $\gamma$ and/or TNF- $\alpha$ or other inflammatory mediators. The latter hypothesis is supported by the fact that the increase in serum $\mathrm{NO}_{\mathrm{x}}$ levels observed after inactivation of IL-10 is paralleled by highly elevated TNF- $\alpha$ and IFN- $\gamma$ levels. Therefore, to further elucidate the role of IL-10 in LPS-induced NO release the effects of combined treatment with anti-IL-10 and either anti-IFN- $\gamma$ or anti-TNF- $\alpha$ on serum $\mathrm{NO}_{\mathrm{X}}$ levels were determined.

Whereas anti-IL-10 treatment significantly enhanced serum $\mathrm{NO}_{\mathrm{X}}$ levels in comparison with LPS-control mice, combined treatment with anti-IL-10 and antiIFN- $\gamma$ inhibited this increase in serum $\mathrm{NO}_{\mathrm{X}}$ (Figure 4A). No serum IFN- $\gamma$ was detectable in the animals treated with anti-IL-10 and anti-IFN- $\gamma$ simultaneously (Figure 4B). Furthermore, TNF- $\alpha$ serum levels were decreased from $3402 \pm 786 \%$ of LPS-control values in mice treated with anti-IL-10 alone to $368 \pm 56 \%$ of LPScontrol values in mice treated with both anti-IL-10 and anti-IFN- $\gamma$ (Figure 4C). Together these data suggest that the increase in serum $\mathrm{NO}_{x}$ after anti-IL-10 pretreatment could be mediated by an increase in both IFN- $\gamma$ and TNF- $\alpha$. Further, addition of anti-IFN- $\gamma$ to anti-IL-10 treatment abrogates the decrease in STNF-R75 levels induced by anti-IL- 10 , even a two-fold increase in serum levels of sTNF-R75 was observed (Figure 5A). No effect was observed on serum levels of sTNF-R55 (Figure 5B), suggesting that IFN- $\gamma$ is only involved in the regulation of the release of STNF-R75. 
Figure 4. Anti-IL-10 enhances LPS-induced serum $N O_{x}(A)$, as well as IFN- $(B)$ and $T N F-\alpha$ (C) whereas combined treatment with anti-IL-10 and anti-IFN- $\gamma$ or anti-IL-10 and anti-TNF$a$ inhibits this elevation in serum NO 6 hours after LPS challenge. Data are expressed as mean percentage of LPS-control values $\pm S D$. For normal and LPS-induced serum NOX, IFN$\gamma$ and TNF- $\alpha$ levels see Table 1. 1: LPS treated $(n=10) ; 2$ : anti-IL-10+LPS $(n=10) ; 3$; antiIL-10+anti-IFN $\gamma+L P S \quad(n=5) ;$ 4: anti-IL-10+anti-TNF- $\alpha+L P S \quad(n=10)$. *: $p<0.05$ as compared to treatment with anti-IL-10 mAb alone; \#: $p<0.05$ as compared to LPS-control mice; ND: not detectable.
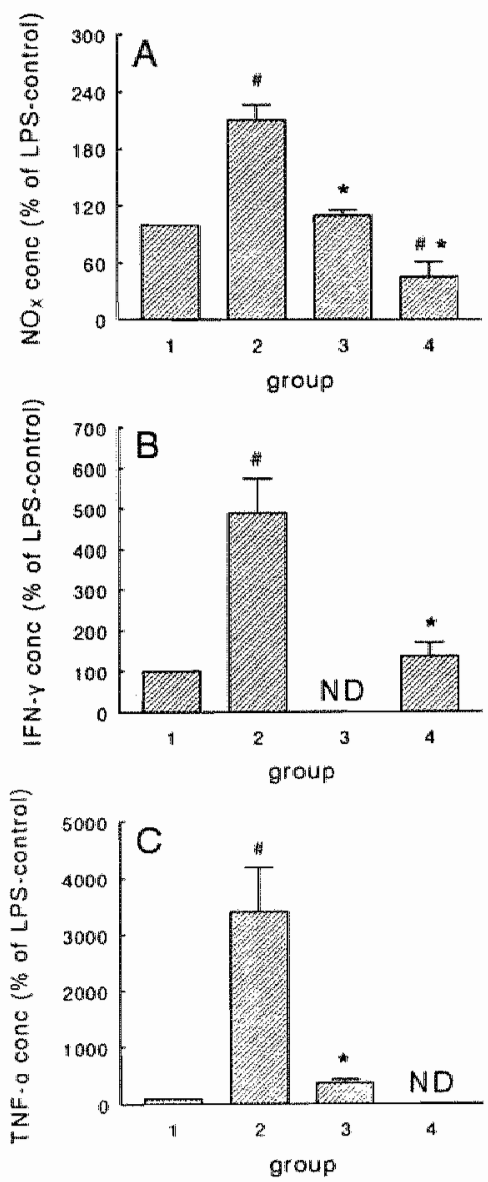

Combined treatment with anti-IL-10 and anti-TNF- $\alpha$ inhibited the increase in serum $\mathrm{NO}_{\mathrm{X}}$ levels as detected in mice treated with anti-IL-10 alone to levels even below that observed in LPS-control mice (Figure 4A). These data suggest involvement of TNF- $\alpha$ in the upregulation of the LPS-induced NO production in the presence of anti-IL-10. 
A low concentration of TNF- $\alpha$ was detected in only one out of ten mice in the combined treated group (Figure $4 \mathrm{C}$ ). Moreover, the fact that simultaneous treatment of anti-IL-10 and anti-TNF- $\alpha$ prevented the increase in serum IFN- $\gamma$ levels as observed in mice treated with anti-IL-10 alone (Figure 4B) support our earlier observation that the increase in serum $\mathrm{NO}_{x}$ after treatment with anti-IL-10 alone is mediated through an upregulation of TNF- $\alpha$ as well as IFN- $\gamma$. These experiments do not elucidate the significance of the increase in IFN- $\gamma$ and/or TNF- $\alpha$ by anti-LL-10 treatment, however, these results strongly suggest that TNF- $\alpha$ plays a more important role than IFN-w. Further, the decrease in \$TNF-R75 levels induced by anti-IL-10 is abrogated by addition of anti-TNF- $\alpha$ to anti-1L-10 treatment (Figure 5A). However, addition of anti-TNF- $\alpha$ to anti-IL-10 treatment strengthens the inhibition of effect of anti-IL-10 on serum levels of STNF-R55 (Figure 5B). These data suggest that TNF- $\alpha$ is involved in the regulation of the release of both $S T N F-R s$.

Figure 5. Anti-1L-10 treatment thhibits LPS-induced serum levels of STNF-R75 (A) and STNF-R5S (B) whereas combined treatment with anti-IFN- $\gamma$ enhances $S T N F-R 75$ levels and combined ireatment with anti-TNF-a amplifies the anti-lL-10 effect on STNF-R55 levels 6 howrs after LPS challenge. Data are expressed as mean percentage of LPS-control values SD. For normal and LPS-induced serum STNFR levels see Table 1. $1:$ LPS treated $(n=10) ; 2$ : anti-LL-10+LPS $(n=10) ; 3:$ anti-LL-10+anti-IFN $\gamma+L P S(n=5) ; 4:$ anti- $L-10+$ anti-TNF$\alpha+L P S(n=10)$. * $p<0.05$ as compared to treatment with ant $-1 L-10 \mathrm{mAb}$ alone. $\#$ : $p<0.05$ as compared to LPS-control mice.
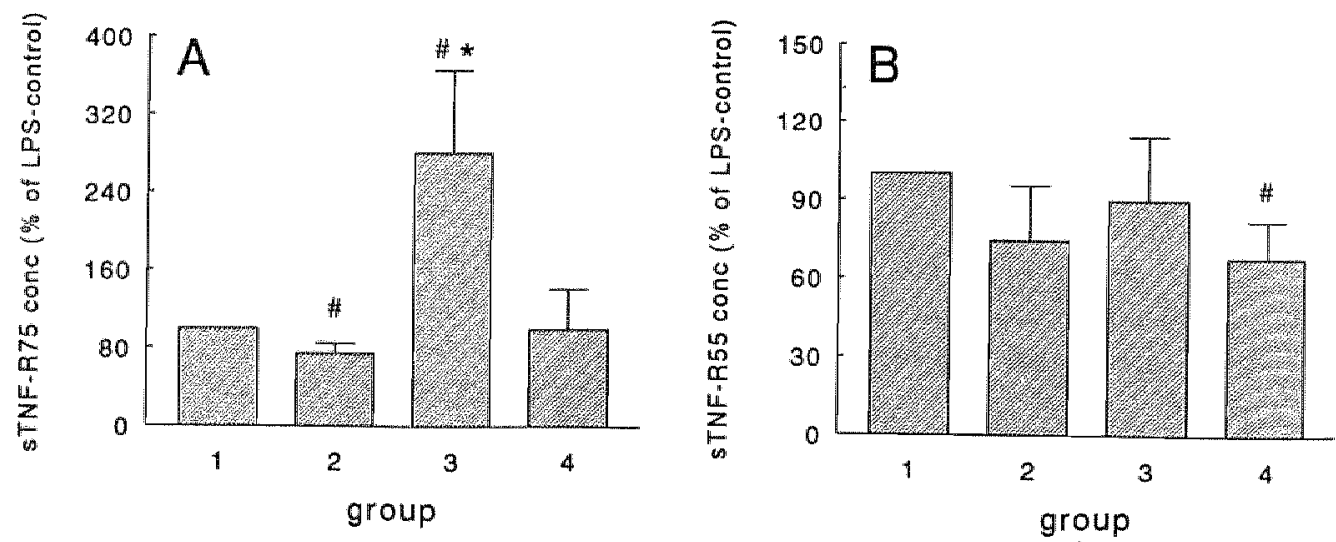


\section{DISCUSSION}

In this study, we investigated the role of endogenous IFN- $\gamma$, TNF- $\alpha$ and IL-10 as proximal mediators in LPS-induced NO release in vivo.

In contrast to in vitro data, blocking of IFN- $\gamma$ alone did not affect LPS-induced NO release 6 hours after LPS administration, suggesting that LPS-induced NO production in wivo is not solely mediated through IFN- $\gamma$. These data are supported by results of Jacobs et al. (32) who showed that during malaria infection in mice blocking of IFN- $\gamma$ did not alter NO release. Further, as reported earlier (18), an increase in STNF-R75 levels was observed after anti-IFN- $\gamma$ treatment, however, statistical significance was not reached.

Although our results indicate that anti-TNF- $\alpha$ treatment was effective since no bioactive TNF- $\alpha$ could be detected and serum $\mathbb{L}-6$ levels were inhibited (3I), no effect of anti-TNF- $\alpha$ mAb pretreatment on LPS-induced serum $\mathrm{NO}_{\mathrm{x}}$ levels was observed. This observation suggests that NO release after LPS challenge is not exclusively mediated through TNF- $\alpha$. Moreover, the experiments with TNF, TNFR55 and TNF-R75 knock out mice confirmed that circulating TNF- $\alpha$ is not crucial for the formation of NO in response to LPS. In line with these data, Vieira et al. (33) showed that TNF-R55 knock out mice were able to produce NO after an infection with Leishmania major. In contrast, Cunha et al. (34) observed a $50 \%$ inhibition of serum $N O_{x}$ levels with anti-TNF- $\alpha$ treatment, 12 hours after LPS injection. We could confirm the effect of anti-TNF- $\alpha$ treatment on late inhibition of serum $\mathrm{NO}_{\mathrm{x}}$ in an additional experiment where serum $\mathrm{NO}_{\mathrm{x}}$ levels were reduced by approximately $20 \%$ at 12 hours (data not shown). These data indicate that TNF- $\alpha$ plays a role in the regulation of the late phase of LPS-induced NO production. However, because considerable tissue damage has already occurred after 12 hours our study focused on the early phase of LPS-induced NO release. Also, murine models using Staphyllococcal Enterotoxin B (SEB) to induce NO production have similarly presented evidence for a role of TNF- $\alpha$ and IFN- $\gamma$ in the late regulation of $\mathrm{NO}$ production (35). However, in the latter study it was not clear whether SEB induced NO release directly through macrophage activation or indirectly via $T$ cell activation. Further, our observation that anti-TNF- $\alpha$ treatment does not affect sTNFR levels 6 hours after LPS challenge are in line with data of Bemelmans et al. (18), who showed that anti-TNF- $\alpha$ treatment affects sTNFR levels until 4 hours after LPS challenge.

Our results obtained by blocking either IFN- $\gamma$ or TNF- $\alpha$ alone indicate that LPSinduced NO release is not solely mediated through either cytokine. However, our results obtained after combined treatment with anti-IFN- $\gamma$ and anti-TNF- $\alpha$ suggest that NO release after LPS challenge is mediated through IFN- $\gamma$ as well as TNF- $\alpha$. Thus, these observations indicate that the presence of either IFN- $\gamma$ or TNF- $\alpha$ is essential for NO production after LPS challenge. These data are supported by Salwkowski et al. (36), who demonstrated that IFN- $\gamma$ knock out as well as TNF-R55 knock out mice produce NO after LPS challenge. 
Interleukin-10, an anti-inflammatory cytokine, is known to downregulate the production of pro-inflammatory cytokines, such as IFN- $\gamma$ and TNF-a (15-16, 37). We investigated whether $\mathrm{L}-10$ inhibits NO release either directly, or indirectly via its. inhibitory effect on the release of pro-inflammatory mediators. Our experiments demonstrated that anti-IL-10 treatment in vivo results in a substantial and significant increase in LPS-induced serum $N O_{X}$ levels. In parallel, significant increases in $\mathbb{L N}-\gamma$, TNE $-\alpha$ and $\mathrm{ML}-6$ levels were observed. These findings are supported by in vitro data of Romani et al. (15), who showed that anti-IL-10 treatment of murine macrophages exposed to yeast enhanced the NO production by these cells. Further, in the latter study, it was demonstrated that anti-IL-10 treatment of mice infected with Candida abicans enhanced the number of IFN- $\gamma$ producing spleen cells. Moreover, previous reported results from in vitro studies support the inhibitory effect of anti-IL-10 on the release of STNF-Rs $(19,38)$. These STNF-Rs are thought to protect the host against the systemic toxicity of TNF- $\alpha$ (18). It is, however, unclear whether the increase in serum $\mathrm{NO}_{\mathrm{x}}$ observed with anti-IL-10 treatment is a direct effect on $\mathrm{NO}$ production by removal of active $1 \mathrm{~L}-10$ from the circulation or an indirect effect, possibly mediated via reduced inhibition of pro-inflammatory mediators e.g. IFN- $\gamma$ and TNF- $\alpha$. To investigate this, mice were pretreated with anti-IL-10 combined with either anti-IFN-y or anti-TNF- $\alpha$. In LPS injected mice, combined treatment with anti-IL-10 and antiIFN- $\gamma$ prevented the increase in serum levels of $\mathrm{NO}_{\mathrm{X}}$ seen after treatment with antiIL 10 alone, suggesting that the increase in serum $\mathrm{NO}_{\mathrm{X}}$ by anti-IL-10 treatment is at least in part mediated by highly elevated IFN- $\gamma$ levels. However, it must be noted that TNF- $\alpha$ levels were also significantly decreased as compared to the levels observed after anti-IL-10 treatment alone, indicating that inhibition of TNF- $\alpha$ could also play a role in the observed inhibition of the $\mathrm{NO}$ release after this combined treatment. Further, these results confirm the observation of our first experiment, using anti-IFN- $y$ alone, which suggested that elevated levels of TNF- $\alpha$ alone are enough for LPSinduction of NO release. Surprisingly, addition of anti-IFN- $\gamma$ to anti-IL-10 treatment abrogates the inhibitory effect of anti-IL-10 on STNF-R75 serum levels. Soluble TNFR75 levels were even significantly enhanced suggesting that IFN- $\gamma$ is involved in the regulation of serum sTNF-R75 levels.

Combined pretreatment with anti-IL-10 and anti-TNF- $\alpha$ mAbs also prevented the increase in serum $\mathrm{NO}_{\mathrm{x}}$ levels as observed after pretreatment with anti- $\mathrm{IL}-10$ alone. Further, serum IL-6 levels were inhibited by this combined treatment as compared to anti-IL- 10 treatment alone confirming that anti-TNF- $\alpha$ treatment was effective. Thus, it appears that inactivation of high levels of TNF- $\alpha$, present after anti-IL-10 $\mathrm{mAb}$ treatment, inhibits the enhanced LPS-induced NO release. Surprisingly, after combined treatment with anti-IL-10 and anti-TNF- $\alpha$ even lower $(<55 \%)$ serum $\mathrm{NO}_{K}$ levels were observed than those in LPS-control mice. This might be explained by the fact that in these mice, serum IFN- $\gamma$ levels were significantly lower compared with the increased levels after anti-IL-10 treatment alone, and even equalled those detected in LPS-control mice. Taken together, our data indicate that both TNF- $\alpha$ and IFN- $\gamma$ are 
involved in the induction of NO release after LPS injection, and that TNF- $\alpha$ is an important mediator involved in the induction of IFN- $\gamma$ production, as demonstrated previously (39).

However, in addition to IFN- $\gamma$ and TNF- $\alpha$ an IL-10 induced factor, which stimulates NO production, seems to be involved in the regulation of LPS-induced NO release. This conclusion is based on the observation that IFN- $\gamma$ levels in mice treated with anti-TNF- $\alpha$ alone were lower than those observed in the group treated with both anti-IL-10 and anti-TNF- $\alpha$ and the fact that treatment with anti-TNF- $\alpha$ alone had no effect on LPS-induced NO release. The observation that addition of anti- $\mathbb{L}-10$ to antiTNF- $\alpha$ treatment led to an inhibition of the NO response whereas IFN- $\gamma$ levels remained near LPS-induced levels, indicates that an IL-10 induced mechanism is abrogated. This IL-10 induced mechanism is not abrogated in the mice treated with either anti-IFN- $\gamma$, anti-TNF- $\alpha$ or both anti-IFN- $\gamma$ and anti-TNF- $\alpha$ simultaneously. Further, addition of anti-TNF- $\alpha$ to anti-IL-10 treatment amplifies the effect of anti-IL10 on sTNF-R55 levels and abrogates the inhibitory effect of anti-IL-10 on STNF-R75 levels, supporting previous reported data that TNF- $\alpha$ is involved in the regulation of both sTNF-Rs (18).

In conclusion, this study demonstrates that IFN- $\gamma$, TNF- $\alpha$ as well as IL-10 are involved in the regulation of NO release after LPS challenge. Our data suggest that LPS injection induces increased TNF- $\alpha$ levels which stimulates next to LPS the observed increase in IFN- $\gamma$ production. Further, LPS-induced NO release is mediated through both TNF- $\alpha$ and IFN- $\gamma$. However, increased serum levels of either TNF- $\alpha$ or IFN- $\gamma$ are sufficient for NO release after LPS challenge, indicating that LPS-induced NO release is mediated through at least two pathways. Interleukin-10 production induced after LPS challenge regulates the LPS-induced NO release by inhibition of the LPS-induced TNF- $\alpha$ and IFN- $\gamma$ production. In addition, evidence was obtained for a thusfar unknown factor upregulated by IL-10 is involved in the induction of NO release after LPS challenge.

\section{Acknowledgement}

This work was supported by a grant (1996-20) from the Nutricia Research Foundation, The Hague, the Netherlands.

\section{REFERENCES}

1. Nussler AK, Billiar TR. Inflammation, immunoregulation, and inducible nitric oxide synthase. $J$ Lewkocyle Biol 54: 171-178, 1993.

2. Worall NK, Lazenby WD, Misko TP, Lin TS, Rodi CP, Manning PT, Tilion RG, Williamson JR, Ferguson TB jr. Modulation of in vivo alloreactivity by inhibition of inducible nitric oxide synthase. J Exp Med 181: 63-70, 1995. 
3. Vallance P. Moncada S. Role of endogenous nitric oxide in septic shock. New Horizons 1: 77-86, 1993.

4. Tiao G, Rafferty J, Ogle C. Fischer JE, Hasselgren PO. Detrimental effect of nitric oxide synthase inhibition during endotoxemia may be caused by high levels of nmor necrosis factor and interleukin-6. Surgery 116: 332-338, 1994.

5. Moilanen E, Vapaatalo $\mathrm{H}$. Nitric oxide in inflammation and immune response. Ann Med 27: 359 $367,1995$.

6. Jorens PG, Van Overveld FJ, Bult $H_{*}$ Vermeire PA, Herman AG. L-arginine-dependent production of nitrogen oxides by rat pulmonary macrophages. Eur $J$ Pharmacol 200: 205-209, 1991.

7. Asai K, Kato H, Kimura S, Mukai S, Kawahito Y, Sano H, Kondo M, Akaogi K, Hirose K. Induction of gene expression for nitric oxide by immunomodulating drugs in the RAW264.7 murine macrophage cell line. Cancer Immunol tromun 42: 275-279, 1996.

8. Feinstein DL, Galea $\mathrm{E}$, Roberts $\mathrm{S}$, Berquist $\mathrm{H}$, Wang $\mathrm{H}$, Reis DJ. Induction of nitric oxide synthase in rat C6 glioma cells. J Neurochem 62: 315-321, 1994.

9. Maru A, Jackson SK. Opposite effects of interleukin-4 and interleukin-10 on nitric oxide production in murine macrophages. Mediators Inflam 5: 110 112, 1996.

10. Modolell M, Corraliza IM, Link F, Soler G, Eichmann K. Reciprocal regulation of the nitric oxide synthase/arginase balance in mouse bone marrow-derived macrophages by $\mathrm{TH} 1$ and $\mathrm{TH} 2$ cytokines. Eur I Immunol 25: 1101-1104, 1995.

11. Martin E, Nathan C, Xie Q. Role of interferon regulatory factor 1 in induction of nitric oxide synthase. J Exp Med 180: 977-984, 1994.

12. Zídek Z, Lotzová $\mathbb{E}$, Franková D, Savary $C A$. Indirect stimulatory effects of murine interleukin-12 on in vitro production of nitric oxide by mouse peritoneal cells. I Interferon Cytokine Res 16 : $339-346,1996$.

13. Chen B, Stout R, Campell WF. Nitric oxide production: A mechanism of Chlamydia machomati inhibition in interferon- $\gamma$-treated RAW264.7 cells. FEMS Immumol Med Mic 14 : 109-120, 1996.

14. Yuhas Y, Kaminsky E, Mor M, Ashkenazi S. Induction of nitric oxide production of mouse macrophages by shiga toxin. J Med Microbiol 45: 97-102, 1996.

15. Romani L, Puccetti P, Mencacci A, Cenci E, Spaccapelo R, Tonnetti L, Grohmann U, Bistoni $\mathbb{F}$. Neutralization of IL-10 up-regulates nitric oxide production and protects susceptible mice from challenge with Cardida abicans. J Jmmunol 152: 3514-3521, 1.994.

16. Gérard C, Bruyns C, Marchan A, Abramowicz D, Vandenabeele P, Delvaux A, Fiers W, Goldman $M$, Velu $T$. Interleukin 10 reduces the release of tumor necrosis factor and prevents lethality in experimental endotoxemia. $J \operatorname{Exp} \mathrm{Med} 177$ : 547-550, 1993.

17. Standiford TJ, Strieter RM, Lukacs NW, Kunkel SL. Neutralization of IL-10 increases lethality in endotoxemia, J Immumol 155:2222-2229, 1995.

18. Bemelmans MHA, Gouma DJ, Burman WA. LPS-induced STNF-Receptors release in vivo in a murine model. Investigation of the role of tumor necrosis factor, IL-1, leukemia inhibiting factor, and IFN- $y$. J Immonol $151: 5554-5562,1993$.

19. Leeuwenberg JFM. Jeunhomme TMAA, Bunrman WA. Slow release of soluble TNF receptors by monocytes in vitro. J Immunol $152: 4036-4043,1994$.

20. Perretti $M$, Szabó C. Thiemermann C. Effect of interleukin-4 and interleukin-10 on leucocyte migration and nitric oxide production in the mouse. BrJ Pharmacol 1.16:2251-2257, 1995.

21. Sands WA, Bulut $V$, Severn A, Xu D, Liew FY. Inlibition of nitric oxide synthesis by interleukin-4 may involve inhibiting the activation of protein kinase $\mathrm{C}$ epsilon. Eur I Immunol 24 : 2345-2350, 1994. 
22. Rothe $\mathrm{J}$, Lesslauer $\mathrm{W}$, Lotscher $\mathrm{H}$, Lang $\mathrm{Y}$, Koebel $P$, Kontgen $F$, Althage A, Zinkernagel $\mathbb{R}$, Steinmetz $M$, Bluethmann $H$. Mice lacking the tumour necrosis factor receptor 1 are resistant to TNF-mediated toxicity but highly susceptible to infection by Listeria monocytogenes. Natwre 364: $789-802,1993$.

23. Erickson SL, de Sauvage FJ, Kikly K, Carver Moore K, Pitts Meek S, Gillet N, Sheehan KC, Schreiber $\mathbb{R D}$, Goeddel DV, Moore MW. Decreased sensitivity to tumour-necrosis factor but normal T-cell development in TNF receptor-2-deficient mice. Nature 372:560-563, 1994.

24. Eugster HP, Muller M, Karrer U, Car BD, Schnycler B, Eng VM, Woerly G, Le Hir M, di Padova F, A guet $M$, Zinkernagel $R$, Bluethmann $H$, Ryffel $B$. Multiple immune abnormalities in tumor necrosis factor and lymphotoxin- $\alpha$ double deficient mice. Int Immunol 8: 23-36, 1996.

25. Green LC, Wagner DA, Glogowski J, Skipper PL, Wishnok JS, Tannenbaum ST. Analysis of nitrate, nitrite, and $\left({ }^{15}\right.$ N)nitrate in biological fluids. Anal Biochem 126:131-138, 1982.

26. Dentener MA, Greve JW, Maessen JG, Butuman WA. Role of tumor necrosis factor in the enhanced sensitivity of mice to endotoxin after exposure to lead. Inmunopharm Immunor 11:321$324,1989$.

27. Röllinghoff $M$, Wamer NL. Specificity of in vivo tumor rejection assessed by mixing immune spleen cells with target and unrelated tumor cells. PSEBM 144: 813-818, 1973.

28. Espevik T, Nissen-Meyer J. A highly sensitive cell line, WEHI 164 clone 13, for measuring cytotoxic factor/tumor necrosis factor from human monocytes. I Immunol Methods 95: 99-105, 1986.

29. Hansen $M B$, Nielsen SE, Berg $\mathbb{K}$. Re-examination and further development of a precise and rapid dye method for measuring cell growth/cell kill. J Immunol Methods 119: 203-210, 1989.

30. Aarden LA, De Groot ER, Schaap OL, Lansdorp PM. Production of hybridoma growth factor by human monocytes. Eur J Immunol 17: 1411-1416, 1987.

31. EngeJberts I, Von Asmuth EJU, Van Der Linden CJ, Buurman WA. The interrelation between TNF- $\alpha$, IL-6 and PAF secretion induced by LPS in an in vivo and in vitro murine model. Lymphokine Cytok Res 10: 127-131, 1991.

32. Jacobs P, Radzioch D, Stevenson MM. In wivo regulation of nitric oxide production by tumor necrosis factor alpha and gamma interferon, but not by interlenkin-4 during blood stage malaria in mice. Infect Immun 64: 44-49, 1996.

33. Vieira LQ, Goldschmidt M, Nashleanas M, Pfeffer K, Mak T, Scott P. Mice lacking the TNF receptor $\mathrm{P} 55$ fail to resolve lesions caused by infection with Leishmania major, but control parasite replication. J Immunol 157: 827-835, 1996.

34. Cunha FQ. Assreuy J, Moss DW, Rees D, Leal LMC, Moncada S, Carrier M, O'Donnell CA, Liew $\mathbb{F} Y$. Differential induction of nitric oxide synthase in various organs of the mouse during endotoxaemia: Role of TNF-a and IL-1-13. Intmunol 81:211-215, 1994.

35. Florquin S, Amraoui Z, Dubois C, Decuyper J, Goldman M. The protective role of endogenously synthesized nitric oxide in Staphylococcal Enterotoxin B-induced shock in mice. I Exp Med 180: 1153-1158, 1994.

36. Salkowski CA, Detore G, McNally R, Van Rooijen N, Vogel SN. Regulation of inducible nitric oxide synthase messenger RNA expression and nitric oxide production by lipopolysaccharide in vivo. The roles of macrophages, endogenous IFN- $\gamma$, and TNI receptor-1-mediated signaling. J Immwnol 158: 905-912, 1.997.

37. Barsig J, Küsters $S$, Vogt $K$, Volk HD, Tiegs $G$, Wendel A. Lipopolysaccharide-induced interleukin-10 in mice: role of endogenous tumor necrosis factor- $\alpha$. Eur $J$ Immunol 25: 2888$2893,1995$.

38. Joyce DA, Gibbons DP, Green P, Steer JH, Feldmann M, Brennan FM. Two inhibitors of proinflammatory cytokine release, interleukin-10 and interleukin-4, have contrasting effects on release of soluble p75 tumor necrosis factor receptor by cultured monocytes. Eur J limmunol 24 : $2699-2705,1994$. 
39. Doherty GM, Lange JR, Langstein HN, Alexander HR, Buresh CM, Norton JA. Evidence for IFN$\gamma$ as a mediator of the lethality of endotoxin and tumor necrosis factor- $\alpha$. I Immunol 149: 1666$1670,1992$. 


\section{CHAPTER 7}

REGULATION OF LPS-INDUCED INOS EXPRESSION IN THE MAJOR ORGANS IN A MOUSE MODEL.

THE ROLES OF ENDOGENOUS IFN- $\gamma$, TNF- $\alpha$ AND IL-10.

Ter Steege JCA, Van de Ven WCM, Forget PPh, Buurman WA.

Submitted 


\section{ABSTRACT}

Septic shock induced by injection with lipopolysaccharide (LPS) is known to be accompanied by enhanced nitric oxide (NO) production via activation of the enzyme inducible NO synthase (iNOS). Elevated NO production is thought to play a central role in the development of tissue damage observed during septic shock. IFN- $\gamma$, TNF- $\alpha$ and $1 \mathrm{~L}-10$ have been shown to be involved in the regulation of LPS-induced serum levels of the NO-oxidation products nitrate and nitrite. Therefore, in the present study, we investigated the role of endogenous IFN- $\gamma$, TNF- $\alpha$ and IL-10 in the regulation of LPS-induced tissue iNOS expression in all major organs. To this end, mice were pretreated with anti-IFN- $\gamma$, anti-TNF- $\alpha$, anti-IL-10 monoclonal antibodies (mAbs), or combinations of these, two hours before intraperitoneal LPS-challenge. The results obtained by immunohistochemical staining for iNOS indicate that the small intestine, lung and heart are the major organs involved in NO production and that IFN- $\gamma$, TNF. $\alpha$ as well as $1 \mathrm{~L}-10$ are involved in the regulation of iNOS expression in these organs after LPS-challenge. Blocking either IFN- $\gamma$ or TNF- $\alpha$ has no effect on LPS-induced iNOS expression, whereas blocking both mediators nearly completely prevents iNOS expression after LPS challenge, suggesting that the presence of either IFN- $\gamma$ or TNF- $\alpha$ is essential for LPS-induced iNOS expression in these organs. Anti-IL-10 treatment significantly enluanced iNOS expression in the small intestine and lung. Combined treatment of anti-IL-10 with anti-[FN- $\gamma$ or anti-TNF- $\alpha$ revealed that whereas on the one hand IL-10 inhibits LPS-induced iNOS expression through inhibition of IFN- $\gamma$ and TNF- $\alpha$ release, on the other hand IL-10 or an IL-10 inducible factor is also involved in the upregulation of iNOS expression after LPS challenge.

\section{INTRODUCTION}

Septic shock may result from Gram-negative bacterial infection and is characterized by hypotension, inadequate tissue perfusion, and vascular damage, eventually leading to multiple organ failure and death $(1,2)$. Increased serum levels of the NO oxidation products $\left(\mathrm{NO}_{x}\right)$ nitrite and nitrate have been implicated in the pathogenesis of endotoxic shock in various animal models (3-7) as well as in human septic shock (810). There is considerable evidence that elevated production of $\mathrm{NO}$, a potent vasodilator, plays a central role in the hypotension that characterizes endotoxic shock (10-13). Further, enhanced NO levels are thought to play a central role in endotoxininduced tissue damage, particularly of the intestine (14-17), and increased vascular permeability $(8,18,19)$. Increased iNOS mRNA levels, iNOS expression and enhanced iNOS enzymatic activity have been reported in different organs of LPSchallenged rodents $(4,5,7,17,20,21)$.

Increased production of cytokines, such as TNF- $\alpha$, IFN- $\gamma$ and IL-10 also plays a central role in the pathophysiology of sepsis. Whereas endogenous TNF- $\alpha$ and IFN- $\gamma$ 
are involved in endotoxin-induced tissue injury and lethality (22-25), IL-10 has been shown to inhibit endotoxin-induced TNF- $\alpha$ production and mortality $(26,27)$. Several in vitro studies revealed that TNF- $\alpha$, IFN- $\gamma$ and $I L-10$ are involved in the regulation of NO release after LPS challenge (28-31). In a previous study we have demonstrated that both endogenous IFN- $\gamma$ and TNF- $\alpha$ mediate LPS-induced NO production in vivo as determimed by serum $\mathrm{NO}_{x}$ levels, and that the single presence of either one of these pro-inflammatory mediators is essential for induction of NO production after LPS challenge. Further, it has been demonstrated that IL-10 inhibits LPS-induced NO release by inhibition of IFN- $\gamma$ and TNF- $\alpha$ release (3).

There are indications that iNOS activity is differently regulated in various organs $(5,21,32)$. For example, LPS-induced iNOS activity in the lung has been shown to be significantly higher than in the spleen and heart. Further, iNOS activity in the lung is, in contrast to iNOS activity in the spleen and heart, independent of TNF- $\alpha$ and IL-1. (21). Therefore, in the present study, we investigated the relative contributions of various tissues to NO production by immunohistochemical staining for the enzyme iNOS in a murine endotoxin shock model. Further, the rolle of the endogenous cytokines IFN- $\gamma$, TNF- $\alpha$ and IL-10 in LPS-induced iNOS expression in these organs was determined. Two hours before intraperitoneal LPS injection mice were treated with anti-IFN- $\gamma$ monoclonal antibody (mAb), anti-TNF- $\alpha \mathrm{mAb}$, anti-IL-10 mAb or combinations of these. The effects of these interventions on iNOS expression were investigated by immunohistochemistry and compared to their previously reported effects on serum $\mathrm{NO}_{x}$ levels (3).

\section{MATERIALS AND METHODS}

\section{Reagents}

Lipopolysaccharide (LPS) from Escherichia coli OB55:B5, bovine serum albumin (BSA), and hematoxylin solution were obtained from Sigma (St Louis, MO); avidinbiotinylated-peroxidase (ABC) kit was from Vectastain (Vector Laboratories, Burlingame, CA); 3,3-diaminobenzidine was from Serva (Heidelberg, FRG). Acetone, methanol, hydrogen peroxide, and entellan were obtained from Merck (Darmstadt, FRG) and coated Starfrost object glasses were from Klinipath (Duiven, the Netherlands). NADPH and nitrate reductase were obtained from Boehringer Mannheim (Mannheim, FRG). Goat-anti-rat and goat-anti-rabbit peroxidaseconjugated antibodies were obtained from Jackson Immuno-Research (Westgrove, PA). The neutrophil marker Gr-1 was obtained from Pharmingen (San Diego, CA).

The following agents were obtained through the courtesy of the respective firms or persons: Chimeric TN3 19.12 from Celltech (Slough, UK) is a CDR-grafted antibody of hamster origin of murine IgGI isotype specific for murine TNF; anti-murine IFN- $\gamma$ (F3), anti-murine IL-10 (JES-2A5) and the murine IFN- $\gamma$ ELISA from Hbt (Uiden, the 
Netherlands). Rabbit-anti-murine iNOS antiserum from Dr. J. Cohen (Infectious Disease Unit, Royal Postgraduate Medical School, London, UK) (7); rat anti-mouse macrophage marker F4/80 from Dr. P. Leenen (Dept. of Immunology, Erasmus University Rotterdam, the Netherlands) (33) and rat anti-mouse E-selectin (10E9.6 culture supernatant) from Prof. Dr. D. Vestweber (Max-Planck-Institut für Immunobiologie, Freiburg, FRG) (34).

\section{Animals}

Female Swiss mice (2-6 months) were obtained from Charles River Breeding Laboratories (Heidelberg, FRG), maintained on standard laboratory diet and allowed free access to water. Guidelines of the Committee for Care and Use of Laboratory Animals from the Maastricht University were followed throughout.

TNF/LT- $\alpha$ knock out mice were from Dr. H.P. Eugster (35) (University Hospital Zurich, Dept. of Internal Medicine, Zurich, Switzerland). These mice were bred at the Laboratory of Molecular Biology, University of Gent (Gent, Belgium) according to Belgian and European Union guidelines for the use and care of laboratory animals.

\section{Experimental protocol}

LPS [250 $\mu \mathrm{g}$ in $0.5 \mathrm{ml}$ phosphate-buffered saline (PBS)] was administered by intraperitoneal injection to mice. Two hours before LPS injection the mice were treated by intraperitoneal injection of either $0.5 \mathrm{ml}$ PBS (LPS control group, $n=10$ ), $100 \mu \mathrm{g} \mathrm{F3}$ (anti-IFN- $\gamma, \mathrm{n}=10$ ) in $0.5 \mathrm{ml}$ PBS, $750 \mu \mathrm{g} \mathrm{TN} 3$ (anti-TNF- $\alpha, \mathrm{n}=10$ ) in 0.5 $\mathrm{ml} \mathrm{PBS}, 1 \mathrm{mg}$ JES-2AS (anti-1L-10, $\mathrm{n}=10$ ) in $0.5 \mathrm{ml}$ PBS or various combinations of these antibodies $(n=5)$ at the same concentration and endvolume $(0.5 \mathrm{ml})$. The results were compared with a non-treated control group which received two times $0.5 \mathrm{ml}$ PBS. Six hours after LPS injection, blood was sampled by orbital punction after which the mice were sacrificed by cervical dislocation. Tissues samples of the small intestine, heart, lung, liver, spleen, kidney, and skeletal muscle were collected and immediately frozen in liquid nitrogen.

\section{WEHI 164 cytotoxicity bioassay}

TNF bio-activity was measured using the murine fibrosarcoma WEHI 164 cell line $(36,37)$. The MTT-method was used to assess cell viability as described previously (38). A standard titration curve was obtained by making serial dilutions of a known quantity of murine rTNF. The dilution giving rise to $50 \%$ lysis was correlated with the $\mathrm{L} \mathrm{D}_{50}$ of the standard curve. 


\section{IFN- $\gamma$ ELISA}

Serum IFN- $\gamma$ levels were determined using a mouse IFN- $\gamma$ ELISA kit, kindly provided by $\mathrm{Hbt}$ (Uden, the Netherlands) according to the manufacturers instructions.

\section{Immunohistochemistry}

Frozen tissue sections $(5 \mu \mathrm{m})$ were cut, thaw-mounted onto coated glass slides, fixed in acetone for $10 \mathrm{~min}\left(-20^{\circ} \mathrm{C}\right)$ and air dried. Endogenous peroxidase was blocked by immersing the slides in $0.03 \%$ hydrogen peroxidase in PBS for $30 \mathrm{~min}$, followed by washing in PBS (three washes, 5 min each). After blocking nonspecific binding by incubation with $5 \%$ BSA for $30 \mathrm{~min}$ and subsequent washing, sections were incubated for 1 hour with either rabbit anti-iNOS antiserum or with normal rabbit serum (negative control) diluted in PBS containing $0.1 \%$ BSA and $2 \%$ normal mouse serum. Next, sections were washed with PBS and incubated for 1 hour with biotinylated goat anti-rabbit IgG and subsequently incubated with freshly prepared avidin-biotinperoxidase complex for $45 \mathrm{~min}$. Peroxidase activity was detected using diaminobenzidine as substrate. For staining of liver, spleen and kidney tissue, a peroxidase conjugated goat anti-rabbit antibody was used directly as secondary antibody. Sections were counterstained with hematoxylin, dehydrated, and mounted in entellan.

The same immunohistochemical method was used to stain for macrophages (F4/80, ), neutrophils (Gr-1) and E-selectin (10E9.6) except that a peroxidase labeled goat anti-rat IgG was used as secondary antibody.

\section{Histological analysis}

To determine the cellular source of NO production, small intestine, lung, heart, liver, spleen, kidney, and skeletal muscle were examined for expression of iNOS, F4/80, Gr$\mathbb{I}$ and E-selectin. The number of iNOS positive cells and the intensity of staining was scored semi-quantitatively by two independent observers blinded to the specific treatment of the animals.

\section{RESULTS}

\section{iNOS expression in organ tissue after LPS challenge}

Significantly increased iNOS expression was observed in the small intestine, lung and heart 6 hours after LPS challenge, whereas iNOS expression was not detected in the other organs investigated. Except for a small number of iNOS positive cells in the 
small intestine and the lung, organs in non-treated control mice were negative for iNOS staining (Table 1).

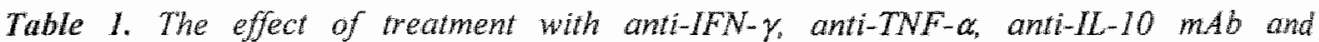
combinations thereof on LPS-induced iNOS expression in different organs. Each group consisted of 5 to 10 mice. Tissue samples were taken 6 hours after LPS injection".

PBS

control
LPS

antibody treatment to:

\begin{tabular}{|c|c|c|c|c|c|c|c|c|}
\hline & & - & $T N F-\alpha$ & $I F N-\gamma$ & $\begin{array}{c}\text { TNF- } \alpha \\
\quad+ \\
\text { IFN- } \gamma\end{array}$ & IL- 10 & $\begin{array}{c}\text { IL-10 } \\
+ \\
\text { IFN- } \gamma\end{array}$ & $\begin{array}{c}\mathrm{IL}-10 \\
+ \\
\mathrm{TNF}-\alpha\end{array}$ \\
\hline \multicolumn{9}{|l|}{$\begin{array}{l}\text { SMALL } \\
\text { INTESTINE }\end{array}$} \\
\hline infiltr cells & + & ++ & ++ & ++ & +2 & +++ & ++ & 4 \\
\hline epithelinm & - & + & + & + & \pm & ++ & - & + \\
\hline endothelium & - & - & - & - & - & + & - & - \\
\hline \multicolumn{9}{|l|}{ LUNG } \\
\hline infiltr cells & + & $+t$ & $+t$ & ++ & + & +++ & + & $t \pm$ \\
\hline $\begin{array}{l}\text { bronchial } \\
\text { epithelium }\end{array}$ & - & ++ & $+t$ & $+t$ & - & $+t$ & - & \pm \\
\hline \multicolumn{9}{|l|}{ HEART } \\
\hline endothelium & - & ++ & ++ & +1 & - & + & \pm & - \\
\hline infiltr cells & - & - & & - & & + & - & - \\
\hline LIVER & - & - & - & - & - & - & - & - \\
\hline SPLEEN & - & - & - & - & - & - & - & - \\
\hline KIDNEY & - & - & - & - & - & - & - & - \\
\hline MUSCLE & - & - & - & - & - & - & - & - \\
\hline
\end{tabular}

- no iNOS staining detected, + : positive iNOS staining, number of + is a relative indication of the number of positive cells in comparison with non-treated control mice. 
In the small intestine, iNOS staining was most prominent in infiltrating cells present in the lamina propria, 6 hours after LPS challenge. Further, some weak iNOS expression in the crypt epithelium was observed (Figure 1A). Because cellular iNOS expression is closely associated to immune defence of macrophages and neutrophils, serial staining with macrophage marker $\mathrm{F} 4 / 80$ and neutrophil marker $\mathrm{Gr}-1$ was performed to investigate the phenotype of the iNOS-positive cells. Staining with these mAbs revealed that the numbers of intestinal macrophages as well as neutrophils are enhanced 6 hours after LPS challenge (data not shown). Further, it was observed that the number of macrophages is far greater than the number of neutrophils. Serial staining of iNOS with F4/80 and Gr-1 revealed that both F4/80 and Gr-1 showed an identical staining pattern as for iNOS, suggesting that the iNOS positive cells in the lamina propria of the intestine are most likely infiltrating macrophages and neutrophils. Based on these results together with the macrophages-like cellular structure of most iNOS positive cells, it was concluded that the majority of the iNOS positive cells in the lamina propria of the small intestine are macrophages.

In the lung, LPS-induced iNOS expression was observed in bronchial epithelium and in alveolar infiltrating cells (Figure 1C). To investigate the phenotype of these iNOS positive cells serial staining with the macrophage and neutrophil markers was performed. Staining with these antibodies revealed that 6 hours after LPS challenge the number of both macrophages and neutrophils are increased in the lung (data not shown). However, the number of neutrophils clearly exceeded the number of macrophages. The iNOS positive cells in the lung consist of cells which have a small round morphology as well as a macrophage-like morphology, therefore it was concluded that the iNOS positive cells in the lung represent both neutrophils and macrophages.

The heart showed iNOS positive staining in the endothelium. This localization was confirmed by serial staining with anti-E-selectin $\mathrm{mAb}$ (data not shown). Further, a faint diffuse iNOS staining was observed in cardiomyocytes (Figure 1E, Table 1).

\section{Role of endogenous IFN- $\gamma$ and TNF- $\alpha$ in LPS-induced iNOS expression}

We have recently reported that increased IFN- $\gamma$ and TNF- $\alpha$ levels are involved in the regulation of NO release after LPS challenge (3). To investigate the role of IFN- $\gamma$ and TNF- $\alpha$ in the regulation of iNOS expression in the small intestine, lung and heart mice were pretreated with the anti-IFN- $\gamma$ mAb F3 or the anti-TNF- $\alpha$ mAb TN3 two hours before LPS challenge.

Pretreatment with either F3 or TN3 did not affect LPS-induced iNOS expression in the small intestine, lung, heart, or in the other organs investigated (Table 1). These results suggest that LPS-induced iNOS expression in the small intestine, lung and heart is not solely mediated through either cytokine. The efficacy of the mAbs was confirmed by determination of serum IFN- $\gamma$ and TNF- $\alpha$ levels (data not shown). Whereas, in only one out of ten mice treated with anti-IFN- $\gamma \mathrm{mAb}$, a small amount of 
serum IFN- $\gamma$ was detected, TNF- $\alpha$ was undetectable in all of the anti-TNF- $\alpha$ treated animals (3).

To further confirm our results indicating that the absence of circulating TNF- $\alpha$ does not affect LPS-induced iNOS expression in these organs, LPS was administered to TNF- $\alpha / L T-\alpha$ knock out mice. Similarly to the wild-type mice treated with LPS with or without anti-TNF- $\alpha$ mAb, TNF- $\alpha / L T-\alpha$ knock out mice showed enhanced iNOS expression in the small intestine (Figure 1F), lung and heart (data not shown), supporting our earlier findings demonstrating that LPS-induced iNOS expression in these organs is not exclusively mediated through TNF- $\alpha$.

In a previous study, we have demonstrated that blocking either IFN- $\gamma$ or TNF- $\alpha$ has no effect on serum $\mathrm{NO}_{\mathrm{x}}$ levels, whereas blocking both cytokines almost completely prevents the increase in serum $\mathrm{NO}_{\mathrm{X}}$ levels after LPS challenge. To investigate whether serum $\mathrm{NO}_{\mathrm{x}}$ levels correlate with iNOS expression in the small intestine, lung and heart, mice were pretreated with anti-IFN- $\gamma$ and anti-TNF- $\alpha$ simultaneously, 2 hours before LPS challenge. As compared to iNOS expression in LPS-control animals, iNOS expression in the small intestine, lung and heart was clearly inhibited in this combined-treatment group (Table 1). In all three organs the observed iNOS expression was reduced to almost the basal levels detected in nontreated control animals, suggesting that the presence of either IFN- $\gamma$ or TNF- $\alpha$ is essential for LPS-induced iNOS expression in these organs.

\section{Role of endogenous IL-10 in LPS-induced iNOS expression}

To investigate whether IL-10 is involved in the regulation of iNOS expression mice were pretreated with the anti-IL-10 mAb JES-2A5. Anti-IL-10 pretreatment clearly enhanced iNOS expression after LPS injection, particularly in the small intestine and lung, suggesting that IL-10 is involved in the regulation of iNOS expression in these organs. In the small intestine the number of iNOS positive cells was significantly enhanced. Furthermore, anti-IL-10 pretreatment induced additional iNOS expression of the intestinal epithelium and endothelium (Figure 1B). Also, the number of iNOS expressing infiltrating cells in the lung was increased (Figure 1D). These results suggest that inflammatory infiltrating cells are the main producers of NO in this murine endotoxemia model and that iNOS expression in these cells is downregulated by endogenous IL-10, either directly or indirectly through inhibition of IFN- $\gamma$ and TNF $-\alpha$.

Next, we examined whether anti-IL-10 treatment induced additional iNOS expression in the organs which were negative for iNOS staining after LPS challenge alone. iNOS expression was not observed in the liver, spleen, kidney, or skeletal muscle after anti-IL-10 treatment, suggesting that serum $\mathrm{NO}_{\mathrm{x}}$ levels are mainly a reflection of iNOS activity in the small intestine, lung and to a lesser extent the heart (Table 1). 
Figure 1. WOS expression in the small intestine (A), in the thing (C) and heart (E), 6 hours after LPS challenge. Anti-IL-10 treatment enhances iNOS expression in the small intestine (B)

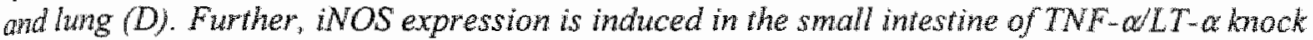
out mice, 6 hours after LPS challenge. Original magnification of intestine tissue is $400 x$ and of hung and heart tissue $200 x$. Intestinal iNOS expression is present in inflammatory cells in the lamina propria (A and F) and crypt epithelium ( $B$ and $F$ ). INOS expression is also present in infammatory cells and bronchial epithelium of the lung $(C$ and $D)$, and epithelium and cardionyocytes of the heart (E).
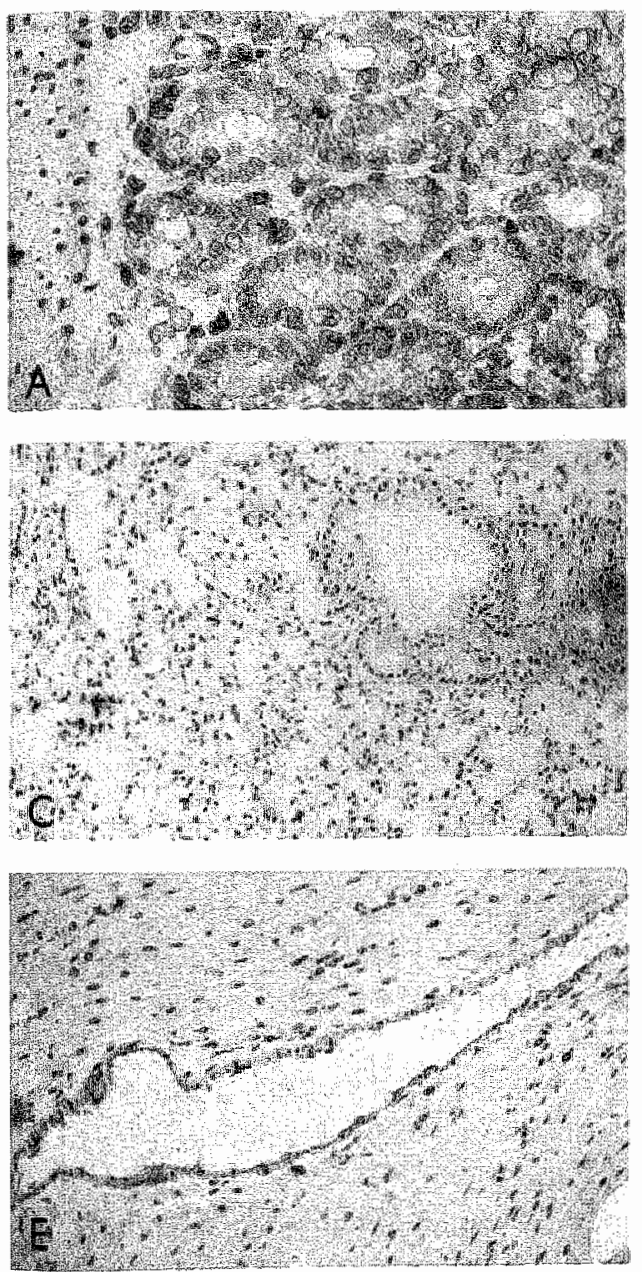
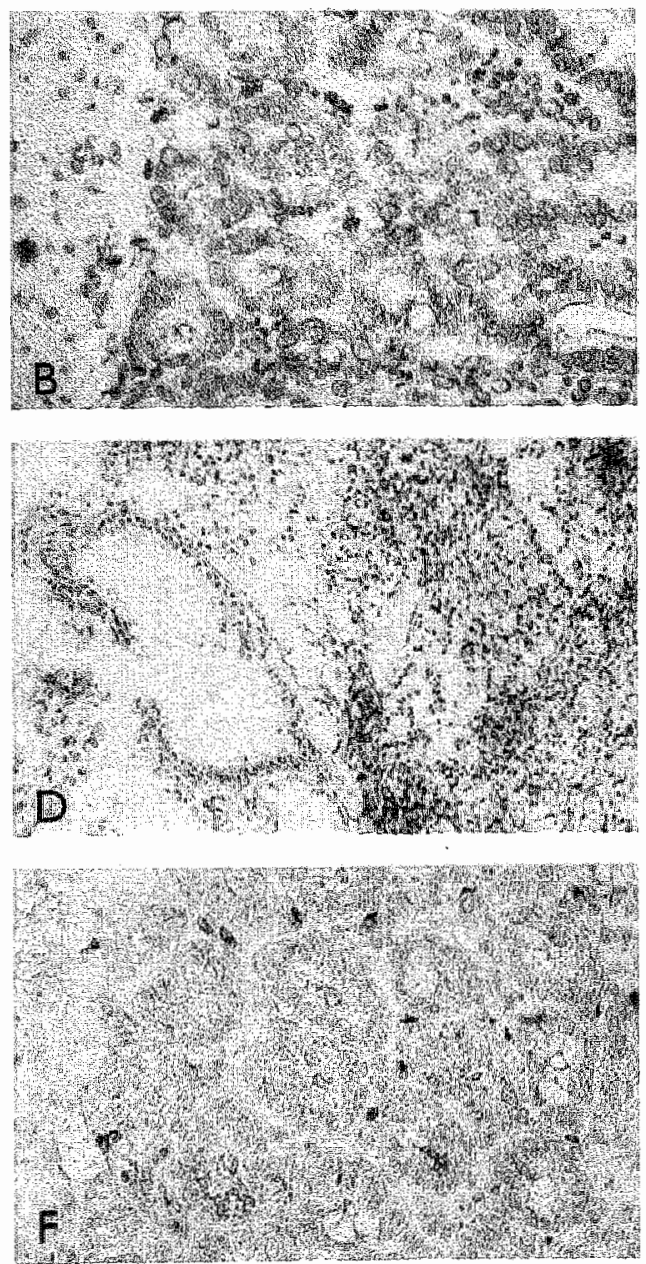
Anti-IL-10 treatment has been shown to enhance LPS-induced TNF- $\alpha$ and IFN- $\gamma$ production (3). Therefore, the role of endogenous IFN- $\gamma$ and TNF- $\alpha$ on LPS-induced iNOS expression in the anti-IL-10 treated animals was investigated by simultaneous pretreatment with anti-IL-10 with either anti-IFN- $\gamma$ or anti-TNF- $\alpha$. Whereas anti-IL10 treatment alone clearly enhanced LPS-induced iNOS expression in the small intestine, combined treatment with anti-IFN- $\gamma$ and anti-IL-10 reduced iNOS expression to levels observed in LPS-control mice. In addition, iNOS expression in the lung and heart was inhibited almost to levels dletected in non-treated control animals (Table 1). These findings suggest that IFN- $\gamma$ is involved in the upregulation of iNOS after anti-IL-10 treatment, particularly in the lung and heart, and to a lesser extent in the small intestine.

Similarly, combined treatment with anti-TNF- $\alpha$ and anti-IL-10 also inhibited the increase in $\mathbb{N}$ NOS expression in the small intestine, lung and heart as observed after anti-IL-10 pretreatment alone (Table 1). In the small intestine and lung iNOS expression was almost inhibited to levels detected in non-treated control mice, whereas iNOS expression in the heart was completely inhibited to non-detectable levels as observed in non-treated control animals. These observations suggest that TNF- $\alpha$ is also involved in the upregulation of iNOS expression after anti-IL-1.0 treatment, particularly in the heart, and to a lesser extent in the small intestine and lung.

\section{DISCUSSION}

Our data demonstrate that, in mice, the small intestine, lung and heart are the major organs involved in enhanced NO production after LPS challenge. Further, LPSinduced iNOS expression is mediated through IFN- $\gamma$ and TNF- $\alpha$, with increased concentrations of either cytokine being essential for enhanced iNOS expression after LPS injection. The resemblance of the effects of anti-IFN- $\gamma$, anti-TNF- $\alpha$ and anti-IL10 pretreatment or combinations thereof on LPS-induced iNOS expression to their effects on serum $\mathrm{NO}_{x}$ levels (3) suggests that iNOS expression in these three organs correlates well with the amount of NO produced systemically, as determined by serum $\mathrm{NO}_{\mathrm{X}}$ levels.

The observation that iNOS expression was only detected in the small intestine, lung and heart of the mice, however, does not imply that other organs are not involved in LPS-induced NO production, but might suggest that iNOS expression in these organs is below detection levels using immuno-histochemical methods. This is illustrated by the fact that enhanced iNOS MRNA levels and NOS activity have been reported in the mouse spleen and liver after LPS challenge (21). Furthermore, in the same study it was shown that NOS activity in the spleen was clearly lower as compared to the NOS activity of the lung and the heart, indicating that less NO is produced in the spleen than in the lung or heart (21). This observation supports our 
results showing undetectable iNOS expression in the spleen in contrast to enhanced iNOS expression in lung and heart.

An increase in intestinal iNOS expression after LPS challenge supports the suggested role for enhanced NO production in the inflammatory response observed in this organ during sepsis. Moreover, we have recently demonstrated that LPS-induced NOS expression in the small intestine coincides with nitrotyrosine formation, which further supports the involvement of enhanced NO production in LPS-induced intestinal damage (39). Inducible NOS expression in the small intestine was largely due to infiltrating inflammatory cells. Although in contrast with Cook et al. (4), who studied LPS-induced INOS expression in rats and reported INOS expression to be present only in the intestinal epithelium, our results are supported by those of Sato et al. (20) who demonstrated also in rats that LPS-induced INOS expression in the small intestine was mainly located in infiltrating inflammatory cells.

In the lung, iNOS expression was detected both in the bronchial epithelium and in tissue infiltrating inflammatory cells. Whereas our results are supported by Buttery et al. (7), in contrast Sato et al. (20) and Cook et al. (4) reported NOS expression in the lung of rats to be present only in bronchial epithelium or in inflammatory cells, respectively. Serial staining with macrophage and neutrophil markers revealed most of the iNOS-positive cells to be macrophages and neutrophils. In the small intestine most of the iNOS positive cells have a macrophage-like structure whereas in the lung iNOS positive cells have both macrophage and neutrophil-like structures. These observations suggest that in the small intestine residing and infiltrating macrophages are the major source of NO production with only a minor contribution of neutrophils, whereas in the lung the iNOS expression by macrophages equals that by neutrophils 6 hours after LPS challenge. In support of the latter Sato et al. (20) showed that the iNOS positive cells in the lung consist of both macrophages and neutrophils.

Endothelial iNOS staining as observed in the heart in this study supports the earlier suggested role for endothelial-derived NO in the hypotension observed during sepsis: (10-13). Although increased NOS activity has been demonstrated in the heart after LPS challenge (21), this is, to our knowledge, the first study that reports endothelial iNOS expression in the heart in mice by immunohistochemical staining. Whereas Buttery et al. (7) and Sato et al. (20) demonstrated the presence of INOS positive infiltrating cells in the heart and some weak iNOS expression in cardiomyocytes, Cook et al. (4) did not observe iNOS expression in the heart after LPS challenge.

Although several studies provided evidence that tissue iNOS expression and $\mathrm{NO}$ production are enhanced after LPS challenge this is the first study that clearly demonstrates a role for endogenous TNF- $\alpha$, IFN- $y$ and IL-10 in LPS-induced iNOS expression in vivo. Moreover, it is shown that INOS expression in the small intestine, lung and heart correlates well with serum $\mathrm{NO}_{\mathrm{X}}$ levels indicating that these organs are the major source of $N O$ production after LPS challenge. Our study using anti-TNF $-\alpha$ and anti-IFN- $\gamma$ mAbs indicates that LPS-induced NOS expression is not mediated through either cytokine solely. The results obtained with TNF- $\alpha$ knock out mice 
further support that TNF- $\alpha$ is not essential for the induction of iNOS expression in the small intestine, lung and heart or, as previously reported, enhanced serum $\mathrm{NO}_{x}$ levels (3) after LPS challenge. In line with this, Cunha et al. (21) showed that anti-TNF- $\alpha$ treatment has no effect on iNOS activity in the lung. In contrast, however, they observed an inhibition of iNOS activity in the heart after anti-TNF- $\alpha$ treatment which might suggest that whereas anti-TNF- $\alpha$ does not affect iNOS expression, it does inhibit the enzyme activity. However, no effect on serum $\mathrm{NO}_{x}$ levels were observed (3). In addition, simultaneous treatment with these mAbs revealed that both IFN- $\gamma$ and TNF- $\alpha$ are involved in the regulation of iNOS expression after LPS challenge as evidenced by the almost complete inhibition of LPS-induced iNOS expression. However, the single presence of either one of these mediators is required for induction of iNOS expression after LPS challenge.

Interleukin-10, an anti-inflammatory cytokine, is known to downregulate the production of pro-inflammatory mediators, such as IFN- $\gamma$ and TNF- $\alpha(27,40)$. Blocking endogenous IL- 10 has been shown to enhance serum levels of $\mathrm{NO}_{x}$, IFN- $\gamma$ and TNF- $\alpha$ (3). We, therefore, investigated whether IL-10 inhibits LPS-induced iNOS expression either directly, or indirectly via its inhibitory effect on the release of proinflammatory mediators. Anti-IL-10 treatment resulted in a substantial increase in the number of iNOS positive cells in the small intestine and the lung. Combined treatment of anti-IL-10 with anti-IFN- $\gamma$ or anti-TNF- $\alpha$ revealed that the increase of iNOS expression induced by blocking endogenous IL-10 is mediated through enhanced IFN $-\gamma$ and TNF- $\alpha$ levels. Moreover, the observation that combined treatment with anti-IL-10 and either anti-TNE- $\alpha$ or anti-IFN- $\gamma$ of LPS challenged mice results in inhibition of iNOS expression to levels below those observed in mice treated with LPS alone suggests that IL-10, or a mediator induced by IL-10, is involved in the upregulation of iNOS expression after LPS challenge in mice.

The results of this intervention study demonstrate that LPS-induced iNOS expression is differentially regulated in the various organs. Furthermore, there is a correlation between serum $\mathrm{NO}_{\mathrm{X}}$ levels and iNOS expression in the small intestine, lung and heart. There seem to be at least two pathways for LPS to induce iNOS expression, one through TNF $-\alpha$ and one through IFN- $\gamma$. However, the presence of only one of either pro-inflammatory cytokine appears to be essential for induction of iNOS after LPS challenge. Further, the results obtained using anti-IL-10 indicate that although IL-10 inhibits LPS-induced iNOS expression by downregulation of TNF- $\alpha$ and IFN- $\gamma, \mathrm{IL}-10$ or an IL-10-induced factor is also involved in the upregulation of LPS-induced iNOS expression.

\section{Acknowledgements}

This work was supported by a grant (1997-E5), from the Nutricia Research Foundation, The Hague, The Netherlands. The authors would like to thank Dr. P. Brouckaert (Laboratory of Molecular Biology, Gent University and Flanders 
Interuniversity Institute for Biotechnology, Gent, Belgium) for the experimental facility and the use of the TNF- $\alpha$ knock out mice and M. Daemen for helping with collection of all murine organs.

\section{REFERENCES}

1. Bone RC. The pathogenesis of sepsis. Ann Int Med 115:457-469, 1991.

2. Parillo JE. Pathogenic mechanisms of septic shock. N Eng JMed 328: 1471-1477, 1993.

3. Ter Steege JCA, van de Ven MWCM, Forget PPh, Brouckaert P, Buurman WA. The role of endogenous IFN- $\gamma$, TNF- $\alpha$ and IL-10 in LPS-induced nitric oxide release in a mouse model. Cylokine 10: 115-123, 1998

4. Cook HT, Bune AJ, Jansen AS, Taylor GM, Loi RK, Cattell V. Cellular localization of nitric oxide synthase in experimental endotoxin shock in the rat. Clin Sci 87: 179-186, 1994.

5. Salkowski CA, Detore G, McNally R, wan Rooijen N, Vogel SN. Regulation of inducible nitric oxide synthase messenger RNA expression and nitric oxide production by lipopolysaccharide in vivo. The roles of macrophages, endogenous IFN- $\gamma$, and TNF receptor-1-mediated signaling. $I$ Immunol 158: 905-912, 1997.

6. Tavares-Murta BM, Cunha FQ, Ferreira SH. Differential production of nitric oxide by endotoxinstimulated rat and mouse neutrophils. Braz J Med Biol Res 29: 381-388, 1996.

7. Buttery LDK, Evans TJ, Springdall DR, Carpenter A, Cohen J, Polak JM. Immunohistochemical localization of inducible nitric oxide synthase in endotoxin-treated rats. Lab Invest 71: 755-764, 1994.

8. Vallence $\mathrm{P}$, Moncada $\mathrm{S}$. Role of endogenous nitric oxide in septic shock. New Horizons 1: 77-86, 1993.

9. Dchoa JB, Udekwu AO, Billiar TR et al. Nitrogen oxide levels in patients following trauma and during septic shock. Ann Surg 214:621-626, 1991.

10. Petros A, Bennett D, Vallance P. Effect of nitric oxide synthase inhibitors on hypotension in patients with septic shock. Lancet 338: 1557-1558, 1991.

11. Gardiner SM, Kemp PA, March JE, Bennett $T$. Cardiac and regional heamodynamics, indicible nitric oxide synthase (NOS) activity, and the effects of NOS inhibitors in conscious, endotoxaemic rats. Br.JPharmacol 116:2005-2016, 1995.

12. Gray GA, Schott CS, Julou-Schaeffer G, Fleming I, Parrat IR, Stoclet JC. The effect of inhibitors of the L-arginine/nitric oxide pathway on endotoxin-induced loss of vascular responsiveness in anaesthetized rats. Br J Pharmacol 103: 1218-1224, 1991.

13. Wrigth $C E$, Rees $D D$, Moncada S. Protective and pathological roles of nitric oxide in endotoxin shock. Cardiovasc Res 26: 48-???, 1992.

14. Tepperman BL, Brown JF, Whittle BJR. Nitric oxide synthase induction and intestinal epithelial cell viability in rats. Am $J$ Pysiol 265 : G214-218, 1993.

15. Mercer DW, Smith GS, Cross JM, Russell. DH, Chang L, Cacioppo J. Effects of lipopolysaccharide on intestinal injury: Potential role of nitric oxide and lipid peroxidation. $J$ Surg Res 63: 185-192, 1996.

16. Wilmore DW, Smith RI, O'Dwyer ST, Jacobs DO, Ziegler TR, Wang XD. The gut: A central organ after surgical stress. Surgery 104: $917-923,1988$.

17. Chen $K$. Inoue $M$, Okada $A$. Expression of inducible nitric oxide synthese mRNA in rat digestive tissues after endotoxin and its role in intestinal mucosal injury. Biochem Bioph Res Commun 224 : 703-708, 1996.

18. Nussler AK, Billiar TR. Lnflammation, immunoregulation, and inducible nitric oxide synthase. $J$ Leskac Biol 54: 171-178, 1993. 
19. Brighan KL. Meyrick. B. Endotoxin and lung injury. Am Rev Respir Dis 133:913-927, 1986.

20. Sato K, Miyakawa K, Takeya M, Hattori R, Yui Y, Sunamoto M, Ichimori Y, Ushio Y, Takahashi K. Inmunohistochemical expression of inducible nitric oxide synthase (iNOS) in reversible endotoxic shock studied by a novel monoclonal antibody against rat iNOS. $J$ Leukoc Biol 57: 36\% 44,1995 .

21. Cunha FQ, Assreuy J, Moss DW, Rees D, Leal LMC, Moncada S, Carrier M, O'Donall CA, Liew FY. Differential induction of nitric oxide synthase in various organs of the mouse during

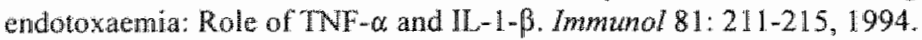

22. Beutler B. Milsark IW, Cerami AC. Passive immunization against cachectin/tumor necrosis factor protects mice from lethal effect of endotoxin. Science $229: 869-871,1985$.

23. Mathison JC, Wolfson E, Ulevitch RJ. Participation of tumor necrosis factor in the mediation of Gram negative bacterial lipopolysaccharide-induced injury in rabbits. I Clin Invest 81: 19251937. 1988.

24. Heremans $\mathrm{H}_{\text {, }}$ Van Damme $J$, Dillen $C$, Dijkmans $R$, Billiau $A$. Interferon $\gamma$, a mediator of lethal lipopolysaccharide-induced Schwartzman-like shock reactions in mice. $J$ Exp Med 171: 1853$1869,1990$.

25. Heinzel FP. The role of IFN- $\gamma$ in the pathology of experimental endotoxemia. I Immunol 145: $2920-2924,1990$.

26. Gerard C, Bruyns C, Marchant A, Abramowicz D, Vandenabeele P. Delvaux A, Fiers W, Goldman M, Velu T. Interleukin 10 reduces the release of tumor necrosis factor and prevents lethality in experimental endotoxemia. $J \operatorname{Exp}$ Med 177: 547-550, 1993.

27. Standiford TJ, Strieter RM, Lukacs NW, Kunkel SL. Neutralization of IL-10 increases lethality in endotoxemia. Cooperative effects of macrophage inflammatory protein-2 and tumor necosis factor. J Immunol 155: 2222-2229, 1995.

28. Asai K, Kato H, Kimura S, Mukai S, Kawahito Y, Sano H, Kondo M, Akaogi K, Hirose K. Induction of gene expression for nitric oxide synthase by immunomodulating drugs in the RAW264.7 murine macrophage cell line. Cancer Jnmunol Immun 42: 275-279, 1996.

29. Moclolell M, Corraliza IM, Link F, Soler G, Eichmann K. Reciprocal regulation of nitric oxidase synthase/arginase balance in mouse bone marrow-dlerived macrphages by TH1 and TH2 cytokines. Eur J Immumol 25: 1101-1104, 1995.

30. Martin $\mathrm{E}$, Nathan $\mathrm{C}$, Xie $\mathrm{Q}$. Role of interferon regulatory factor 1 in induction of nitric oxide synthase I Exp Med 180: 977-984, 1994.

31. Romani L, Puccetti P, Mencacci A, Cenci E, Spaccapelo R, Tonnetti L, Grohmann U, Bistoni $F$. Neutralization of $1 \mathrm{~L}-10$ up-regulates nitric oxide production and protects susceptible mice from challenge with Candida albicans. J Inmmol 152:3514-3521, 1994.

32. Knowles RG, Merrett $M$. Salter M, Moncada $S$. Differential induction of brain, lung and liver nitric oxide synthase by endotoxin in the rat. Biochem $y 270: 833-836,1990$.

33. Austyn JM. Gordon S. F4/80, a monoclonal antibody directed specifically against the mouse macrophage. Ew J Immunal 11:805-815, 1981 .

34. Bosse R, Vesiweber D. Only simultaneous blocking of the $L$ - and P-selectin completely inhibits neutrophil migration into mouse peritoneum. Eur JImmunol 24:3019-3024, 1984 .

35. Eugster HP, Milller M, Karrer U, Car BD, Schnyder B, Eng VM, Woerly G, Le Hir M, Di Padova F. Aguet M, Zinkernagel $R$, Bluethmann $H$, Ryffel B. Multiple immune abnormalities in tumor necrosis factor and lymphotoxin- $\alpha$ double-deficient mice. Int Immumol 8: 23-36, 1996.

36. Rollinghoff $M$. Warner NL. Specificity of in vivo tumor rejection assessed by mixing immune spleen cells with target and unrelated tumor cells. PSEBM 144: 813-818, 1973.

37. Espevik T, Nissen-Meyer J. A highly sensitive cell line, WEH 164 clone 13, for measuring cytotoxic factor/tumor necrosis factor from human monocytes. J Immunol Methods 95: 99-105, 1986. 
38. Hansen MB, Nielsen SE, Berg K. Re-examination and further development of a precise and rapid dye method for measuring cell growth/cell kill. I Immunol Methods 119:203-210, 1989.

39. Ter Steege JCA, Forget PPh, Bunrman WA. Oral spermine administration inhibits intestinal NO production and the systemic inflammatory response in a mouse endotoxin model. Submirted.

40. Barsig J, Küsters S, Vogt K, Volk HD, Tiegs G, Wendel A. Lipopolysaccharide-induced interleukin- 10 in mice: role of endogenous tumor mecrosis factor- $\alpha$. Eur I lmmumol 25: 2888$2893,1995$. 
$-142-$ 


\section{CHAPTER 8}

THE ANTI-INFLAMMATORY ACTIONS OF POLYAMINES ARE MEDIATED BY POLYAMINE OXIDASE AND ARE RELATED TO CYTOTOXICITY

Ter Steege JCA, Forget $\mathrm{PPh}$, and Buurman WA.

Submitted 


\section{ABSTRACT}

Polyamines are thought to play a role in the down regulation of the immune response. The effect of the polyamines, spermine, spermidine, putrescine and cadaverine, on the release of the pro-inflammatory cytokines IL-6, IL-8 and TNF- $\alpha$ and the antiinflammatory cytokine IL-10 by PHA- and LPS-stimulated human PBMCs and monocytes was investigated. The immunosuppressive effects of polyamines are suggested to be mediated by the formation of aldehydes by polyamine oxidase. Therefore, the role of polyamine oxidase was studied using human serum, which lacks polyamine oxidase, next to BCS, which contains polyamine oxidase, and the two polyamine oxidase inhibitors hydroxylamine and isonicotonic acid. We demonstrate that polyamines by themselves elicit neither pro- nor anti-inflammatory properties. However, in the presence of polyamine oxidase, polyamines are oxidized into metabolites that exert pro-inflammatory properties i.e. enhance the release of $\Pi-6$, IL-8 and TNF- $\alpha$, if low concentrations of polyamines are used. In contrast, when higher concentrations of polyamines are used PHA- and LPS-induced IL-6, IL-8, TNF- $\alpha$ as well as $I L-10$ release are inhibited. This inhibition was paralleled with a cecrease in cell viability, suggesting that the inhibition of pro- as well as antiinflammatory cytokines was a result of cell death.

\section{INTRODUCTION}

Polyamines are known to be essential for cell proliferation and function (1-4) and have also been implied in the regulation of inflammatory responses (5-7). Endogenous as well as exogenous polyamines have been shown to exhibit a wide variety of immunosuppressive effects. Addition of polyamines to cell cultures led to the inhibition of lymphocyte proliferation, mixed lymphocyte reaction (8-10), histamine release by mast cells ( 11$)$, neutrophil activation $(7,12)$, and of LPS-induced nitric oxide $(13-15)$ and $T N F-\alpha(16,17)$ release by a murine macrophage cell line. Furthermore, polyamine concentration in monocytes and synovial fluid in the joints of patients with theumatoid arthritis showed a negative correlation with monocytic IL -2 production (18-20). Moreover, IL-2 production by these monocytes was upregulated in presence of a polyamine biosynthesis inhibitor, supporting an immunoregulatory role for endogenous polyamines. While in most of aforementioned studies no effect of polyamines on cell viability was observed, in contrast, other studies have indlicated that polyamines are cytotoxic $(8,11,21-25)$.

While the issue whether or not polyamines are cytotoxic is as yet unresolved, controversy also exists with regard to the question whether immunosuppression is mediated by polyamines themselves or by their degradation products $(8-10,11,13$ 16). Polyamines are oxidized by polyamine oxidase (PAO), present in most in virro studies used bovine serum, leading to the formation of aldehydes. These aldehydes, 
especially spermine dialdehyde, are reported to be involved in the immunosuppressive effects of polyamines in vitro $(8-9,11,13-15)$ whereas others have described that these degradation products are cytotoxic $(8)(11)$.

To investigate the possible immunosuppressive effects of polyamines during inflammation in man, we examined the effect of polyamines on LPS- or PHA-induced release of pro-inflammatory cytokines, i.e. IL- 6, IL-8 and TNF- $\alpha$, as well as the antiinflammatory cytokine IL-10 by human peripheral blood mononuclear cells and purified monocytes. In parallel, the effects of polyamines on cell viability was determined. Moreover, the role of PAO therein was studied by using BCS, BCS in combination with PAO inhibitors or human serum (HS), which lacks PAO activity ( 8 , 26), in the culture medium.

\section{MATERIAL AND METHODS}

\section{Reagents}

Spermine, putrescine, cadaverine, lipopolysaccharide (LPS) from E. Coli (O55:B5), hydroxylamine (HA), isonicotonic acid hydrazide (IS) and bovine serum albumin (BSA) were obtained from Sigma (St. Louis, MO). Spermidine was from Janssen Chimica (Geel, Belgium). Lymphoprep was from Nycomed (Oslo, Norway). Phytohaemagglutinin (PHA) 16 was obtained from Murex Diagnostics Ltd (Dartford, UK). Tissue culture plates were from Costar (Cambridge, MA) and ELISA plates from Nunc (Roskilde, Denmark). RPMI 1640, glutamine, penicillin and streptomycin were obtained from Gibco BRL (Gaithersburg, MD). Bovine calf serum (BCS) was from Hyclone (Logan, UT). Sulphuric acid was from Merck (Darmstadt, Germany). Methyltetrazolium (MTT; (3-[4,5-dimethylthiazol-2-yl]-2,5-diphenyltetrazolium bromide) was from Boehringer Mannheim (Mannheim, Germany). Human recombinant TNF- $\alpha(\mathrm{rTNF}-\alpha)$ was kindly provided by BASF/Knoll (Ludwigshafen, FRG). Human rIL-8 was from Novartis (Vienna, Austria). Recombinant human IL-10 and the hybridoma cell-lines HB1 1676 and HB1 1677 which produce anti-human IL10 monoclonal antibodies were a kind gift from Dr. J.S. Abrams (DNAX, Research Institute of Molecular and Cellular Biology, Palo Alto, CA). Human serum and buffy coats were kindly provided by the Red Cross Blood Bank Zuid-Limburg (Maastricht, the Netherlands). Blood was donated by human volunteers, after informed consent for research was obtained.

\section{Cell isolation and activation}

Peripheral blood mononuclear cells (PBMCs) were isolated by density gradient centrifugation of buffy coat cells on Lymphoprep. Monocytes were isolated according to Graziano and Fanger (27) with slight modifications. In short, the isolated PBMCs 
were allowed to clump for 1 hour on ice. Cell clumps, consisting for $80 \%$ to $90 \%$ of monocytes, were separated from the rest of the cells by sedimentation through ice-cold BCS. Both PBMCs and monocytes were cultured in 96-well flat bottom tissue culture plates in medium consisting of RPMI 1640 supplemented with $5 \% \mathrm{BCS}, 2 \mathrm{mM}$ ghutamine, $100 \mathrm{U} / \mathrm{ml}$ penicillin and $100 \mu \mathrm{g} / \mathrm{ml}$ streptomycin. The cells were preincubated in the absence or presence of different concentrations of spermine, spermidine, putrescine or cadaverine, respectively, for one to two hours, and were subsequently stimulated with either $0.25 \mu \mathrm{g} / \mathrm{ml}$ PHA or $100 \mathrm{ng} / \mathrm{ml}$ LPS (final concentration). The supernatant was harvested after a 4 and a 20 hour incubation period and kept at $-20^{\circ} \mathrm{C}$ until determination of cytokine content. The polyamine solutions were free of endotoxin as determined by the $\mathrm{LAL}$ assay.

\section{TNF- $\alpha$, IL-6, IL-8 and IL-10 ELISA}

Cytokine concentrations in culture supernatant were determined using previously described sandwich ELISA's for TNF- $\alpha$ (28), IL-6 (29), IL-8 (30) and IL-10 (31). In short, plates were coated overnight at $4^{\circ} \mathrm{C}$ with cytokine-specific murine mAbs $61 E 71,5 E 1,3 E 3$, and HB1 1677 for TNF- $\alpha$, IL-6, IL-8, and IL-10, respectively. After blocking and washing the plates, test samples were added and incubated for 1 hour followed by an incubation with biotin labeled polyclonal rabbit IgG anti-human TNF$\alpha$, IL-6, or IL-8 for 1 hour. For the IL-10 ELISA biotin labeled monoclonal antibody HB11676 was used. The subsequent incubation with peroxidase-conjugated streptavidin for $\mathbb{1}$ hour was followed by $T M B$, which was used as substrate. Supernatant of stimulated PBMCs with a standardized concentration of IL-6 was used as IL- 6 standard and human rTNF- $\alpha$, rIL- 8 and rIL-10 were used for standard titration curves in the TNF- $\alpha$, IL- 8 and IL-10 ELISA, respectively. The polyamines did not interfere with the ELISA detection as evidenced by the fact that the standard curves in the presence of polyamines were comparable with the standard curves in normal culture medium (data not shown).

\section{Cell viability}

Cell viability was determined by trypan blue exclusion in parallel with the MTT assay (32). In short, the MTT assay was performed as follows, after removing $150 \mu \mathrm{l}$ from the $200 \mu \mathrm{l}$ supernatant for determination of IL- 6 and IL-8, $50 \mu \mathrm{l}$ fresh culture medium was added to the cells. Subsequently, $25 \mu 1 \mathrm{MTT}$ ( $5 \mathrm{mg} / \mathrm{ml}$ ) was added and incubated for 4 hours at $37^{\circ} \mathrm{C}$. MTT crystals were solubilized with an DMSO/SDS buffer and the cell viability was measured spectrophotometrically at $570 \mathrm{~nm}$. All values were compared to $\mathrm{OD}_{57_{0}}$ of non-treated cells. 


\section{Statistical analysüs}

The Mann-Whitney test was used to determine the statistical significance of difference found between the non-treated and polyamine treated cells. $\mathrm{P}<0.05$ was considered statistically significant. Each experiment was performed in quadruplicate and repeated at least three times.

\section{RESULTS}

\section{Effect of polyamines on cytokine release and cell viability of PBMCs and monocytes}

To investigate the putative immunosuppressive effects of polyamines on human PBMCs and monocytes, the release of pro-inflammatory cytokines such as IL $-6,1 \mathrm{~L}-8$ and TNF- $\alpha$ and the anti-inflammatory cytokine $\mathrm{IL}-10$ by resting and PHA- or LPSstimulated PBMCs and purified monocytes was examined. The cells were cultured for 20 hours in medium containing $5 \% \mathrm{BCS}$ in the presence of a concentration range $(0.1$ - $100 \mu \mathrm{M}$ ) of spermine, spermidine, putrescine or cadaverine.

The results show that in unstimulated cells addition of low concentrations $(\leq 3$ $\mu \mathrm{M}$ ) of spermine and spermidine increased the basal production of IL-6 (Figure 1A), IL-8 (Figure 1B) and $T N \Gamma^{2}-\alpha$ (data not shown), indicating that low concentrations of polyamine have pro-inflammatory effects on PBMCs and monocytes (data not shown). The effect of low concentrations $(<1 \mu \mathrm{M})$ on basal IJ-10 release was not determined. At higher concentrations ( $>10 \mu \mathrm{M}$ ) these polyamines inhibited, the basal release of the pro-inflammatory cytokines $\mathbb{I L}-6, \quad \mathrm{LL}-8$ and $\mathrm{TNF}-\alpha$ as well as the antiinflammatory cytokine IL-10. Interestingly, in parallel with the inhibition of cytokine production a decrease in cell viability (Figure 1D) was observed suggesting that spermine and spermidine are toxic at high concentrations for PBMCs and monocytes (data not shown).

The effect of polyamines on the inflammatory response induced by PHA and LPS was investigated by incubation of cells with polyamines 1 hour before stimulation. Similarly to results obtained on basal cytokine production, low concentrations $(0.1-3$ $\mu \mathrm{M})$ of spermine and spermidine enhanced PHA- and LPS-induced IL-6, IL-8, and $\mathrm{TNF}^{\mathrm{i}}-\alpha$ release. Whereas higher concentrations $(\geq 3 \mu \mathrm{M})$ inhibited the release of both pro-inflammatory as well as anti-inflammatory cytokines by PBMCs (Figure 2) and monocytes (data not shown). These results are in line with above presented results that low concentrations of polyamines exhibit pro-inflammatory action whereas higher concentrations are anti-inflammatory. Moreover, our data indicate that at equimolar concentrations spermine inhibits PHA- or LPS-induced cytokine release more potently than spermidine. A decrease in cell viability was observed when spermine or spermidine were added in high concentrations $(>3 \mu \mathrm{M})$ suggesting that these 
polyamines are cytotoxic at these concentrations and that cell death is responsible for the observed decrease in cytokine release (Figure 2D).

Putrescine and cadaverine affected neither LPS-, PHA-induced IL-6 and IL-8 release by PBMCs (Figure $3 \mathrm{~A}$ and $\mathrm{B}$ ) nor cell viability (Figure $3 \mathrm{C}$ ). These data suggest that these polyamines exhibit neither pro-inflammatory, anti-inflammatory nor cytotoxic actions.

Figure 1. Low concentrations ( $53 \mu M)$ of spermine (open circles) and spermidine (closed" circles) enhance basal release of $I L-6(A)$ and $I L-8(B)$ and inhibit the release of $I L-10$ (C) by $P B M C s$ whereas high concentrations inhibit basal production of all three cytokines. Inhibition of cytokine release corresponds with a decrease in cell viability (D) as determined" by the MTT assay. Cytokine levels and cell viability were determined after a 20 hours incubation period. One representative experiment out of a total of six is depicted.
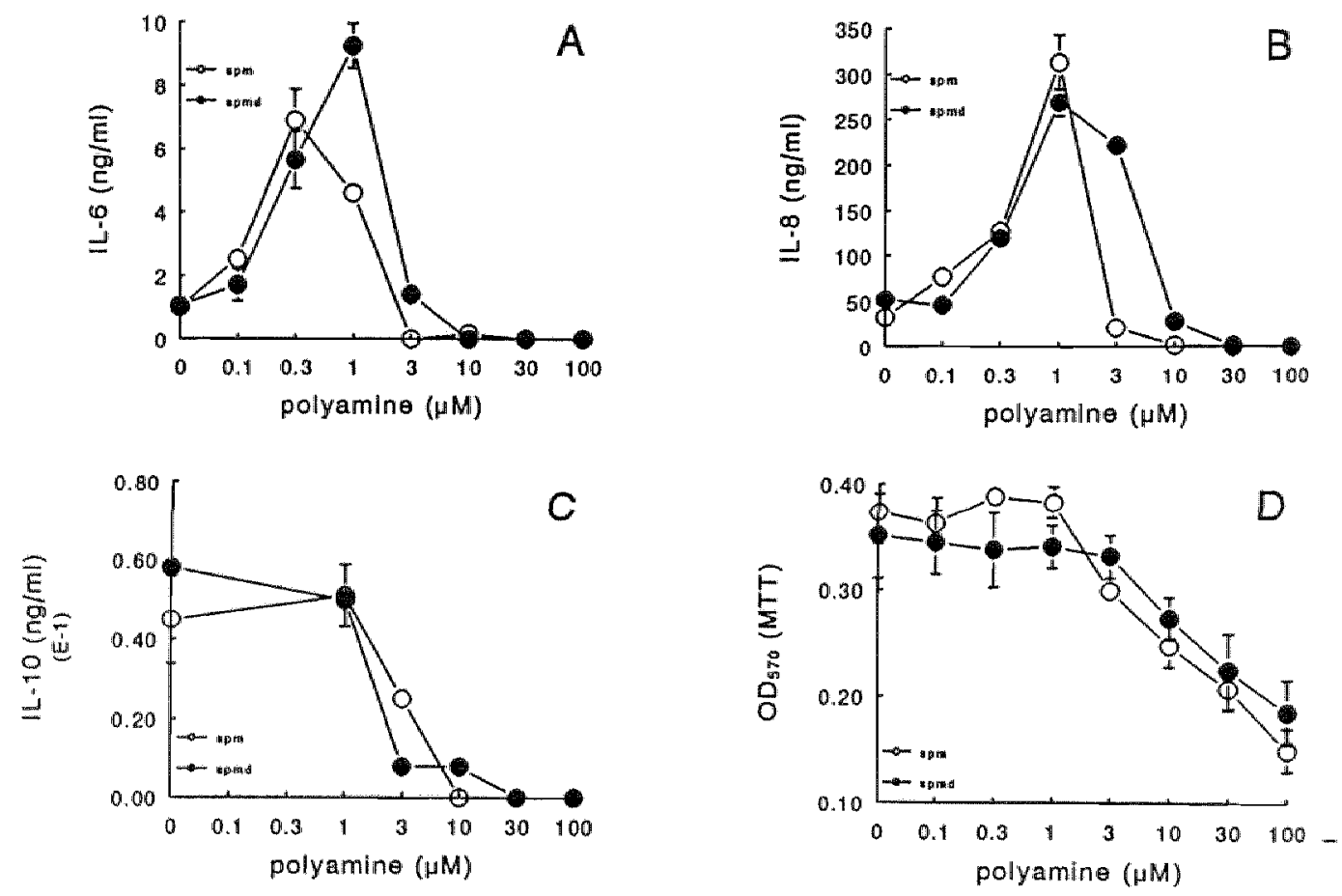

In contrast to our results Zhang et al. (16) reported anti-inflammatory effects of polyamines on LPS-stimulated human monocytes without affecting cell viability during a 4 hours incubation period. To investigate whether the observed cell toxicity 
induced by spermine needs a longer presence of polyamines than 4 hours, the same experiments were performed with a 4 hour incubation and stimulation period. The results obtained after a 4 hour stimulation period demonstrated that, similarly to a 20 hours incubation period, spermine $(>3 \mu \mathrm{M})$ inhibits TNF $-\alpha$, IL-6 and IL-8 release by PBMCs (data not shown) as well as monocytes (Figure 4A). I1-10 levels were below detection limit after a 4 hour culture period (data not shown).

Figure 2. Low concentrations $(\leq 3 \mu M)$ of spermine (open circles) and spermidine (closed" circles) enhance the release of PHA-induced $L-6(A)$ and $L-8$ (B) by PBMCs and hove no significant effect on $I L-10$ release (C) whereas high concentrations inhibit PHA-induced cylokine release. Inhibition of cylokine release corresponds with a decrease in cell viability (D) as determined by the MTT assay. One representative experiment out of a rotal of six is depicted.
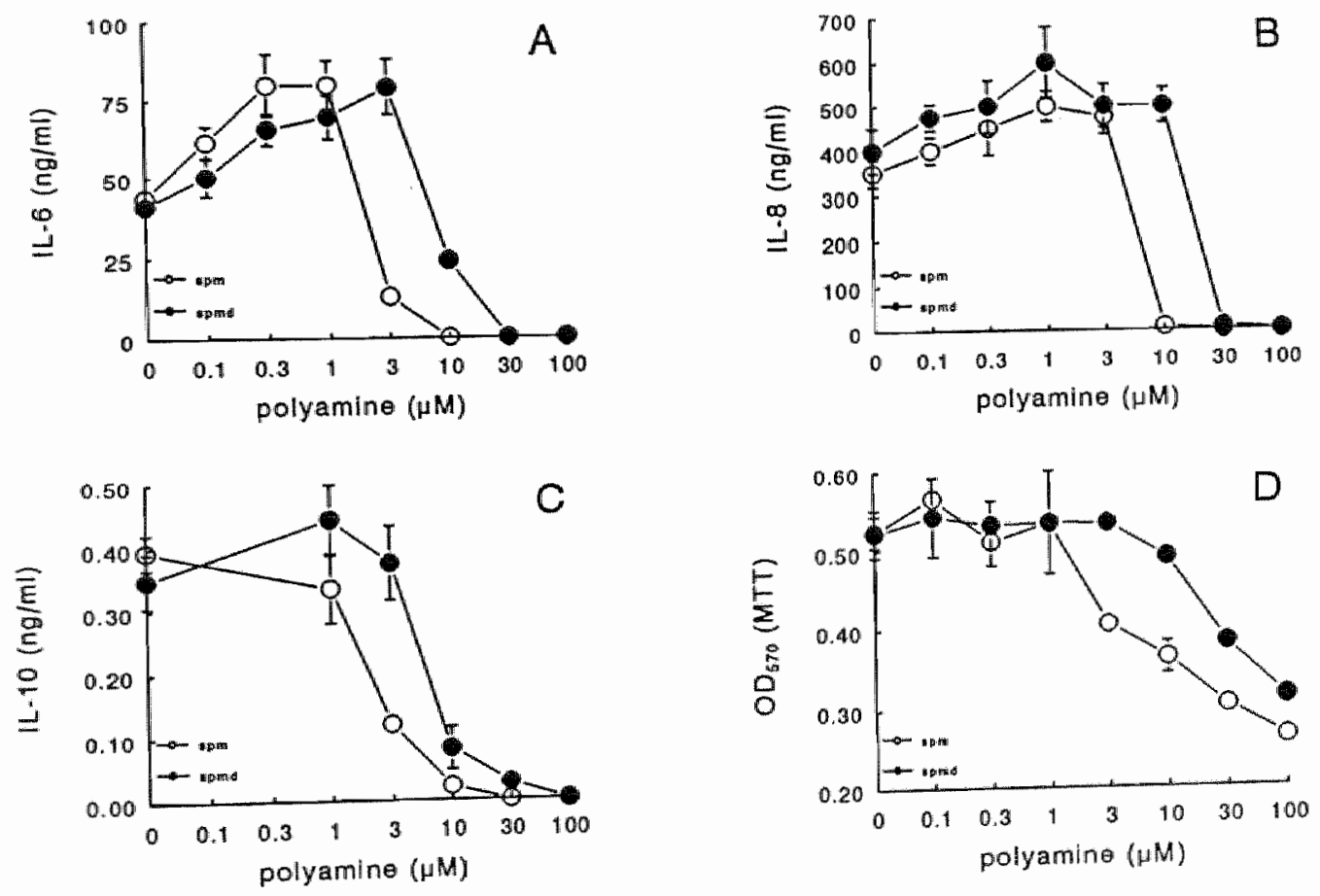
Figure 3. Putrescine (open circles) and cadaverine (closed circles) neither affect PHAinduced $I L-6$ (A) and $I L-8$ (B) release of PBMCS nor cell wiability (C) as determined by the MTT assay. Cylakine levels and cell viability were determined after a 20 hours incubation periad. One representative experiment out of a total of three is depicted.
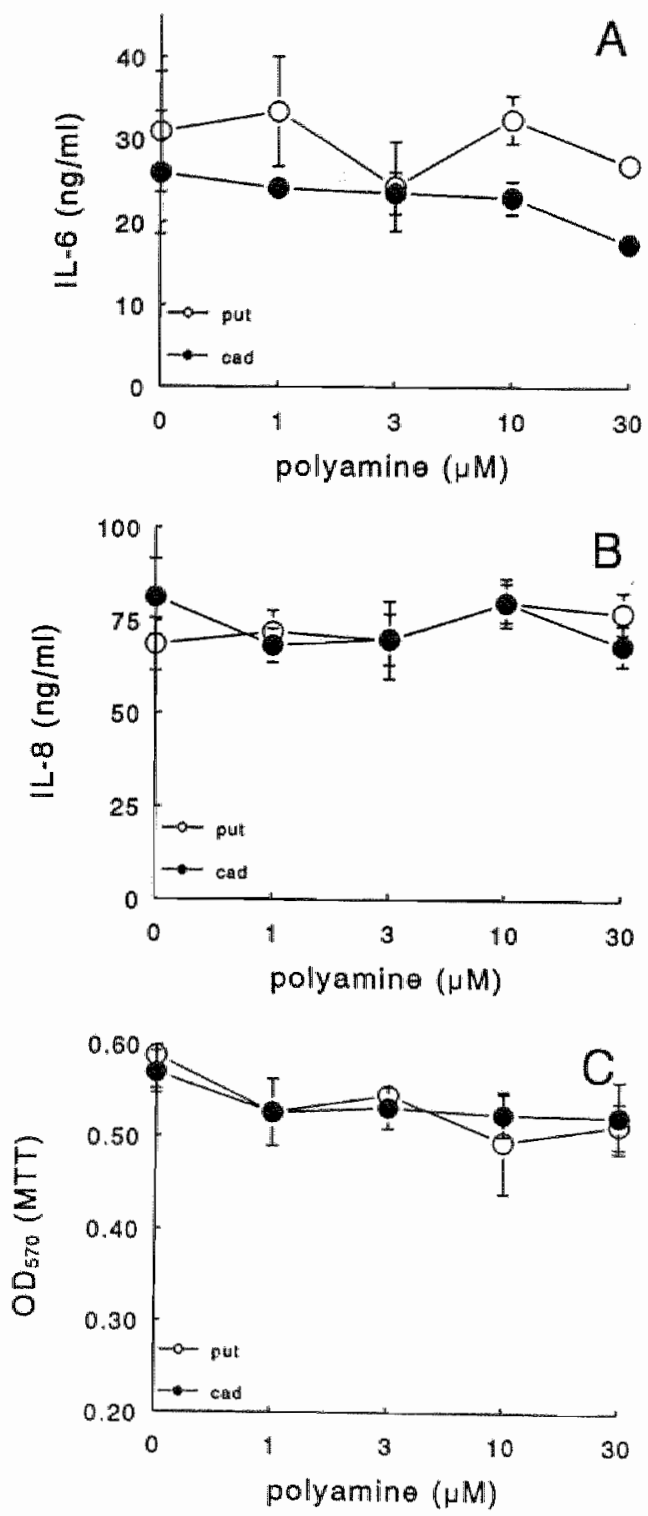
Figure 4. Spermine inhibits LPS-induced IL-6 (open circle), IL-8 (closed circle) and TNF-Q (closed triangle) release by monocytes assessed after a thou sfimulation period (A). Inhibition of cyokine release is paralleled with a decrease in cell viability (B) as determined by the MTT assay after a 4 hours incubation period. One representative experiment out of a lotal of six is depicied.
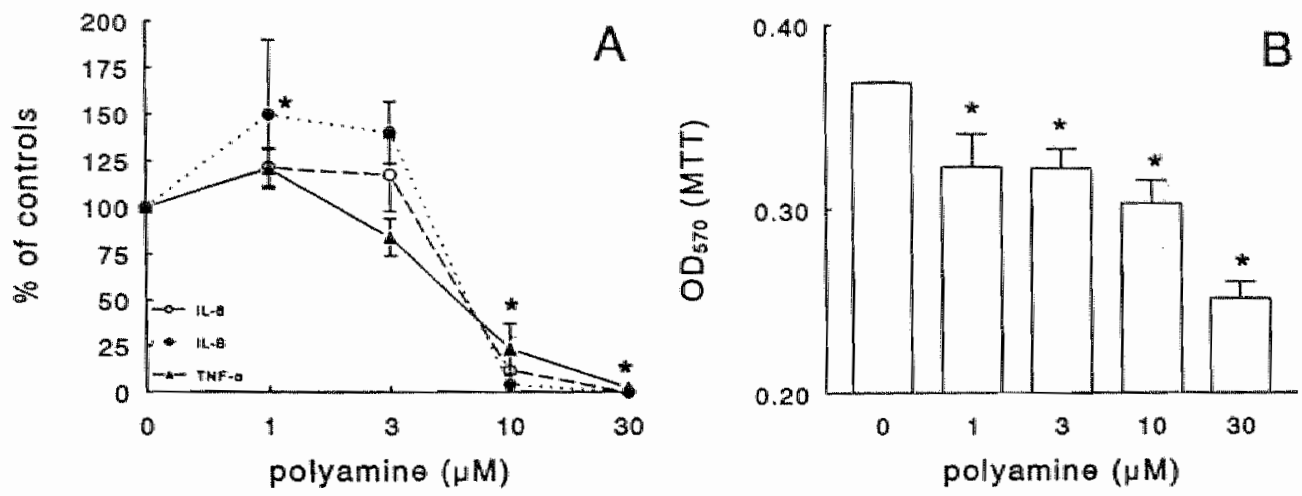

Figure 5. Spermine and spermidine affect neither PHA-induced $I L-6(A), M L-8(B)$, nor $I L-J 0$ (C) release in the presence of human serum. In parallel, no effect on cell viability (D) was observed. Cytokine levels and cell viability were determined after a 20 how's incubation period. One representative experiment out of a total six is depicted.
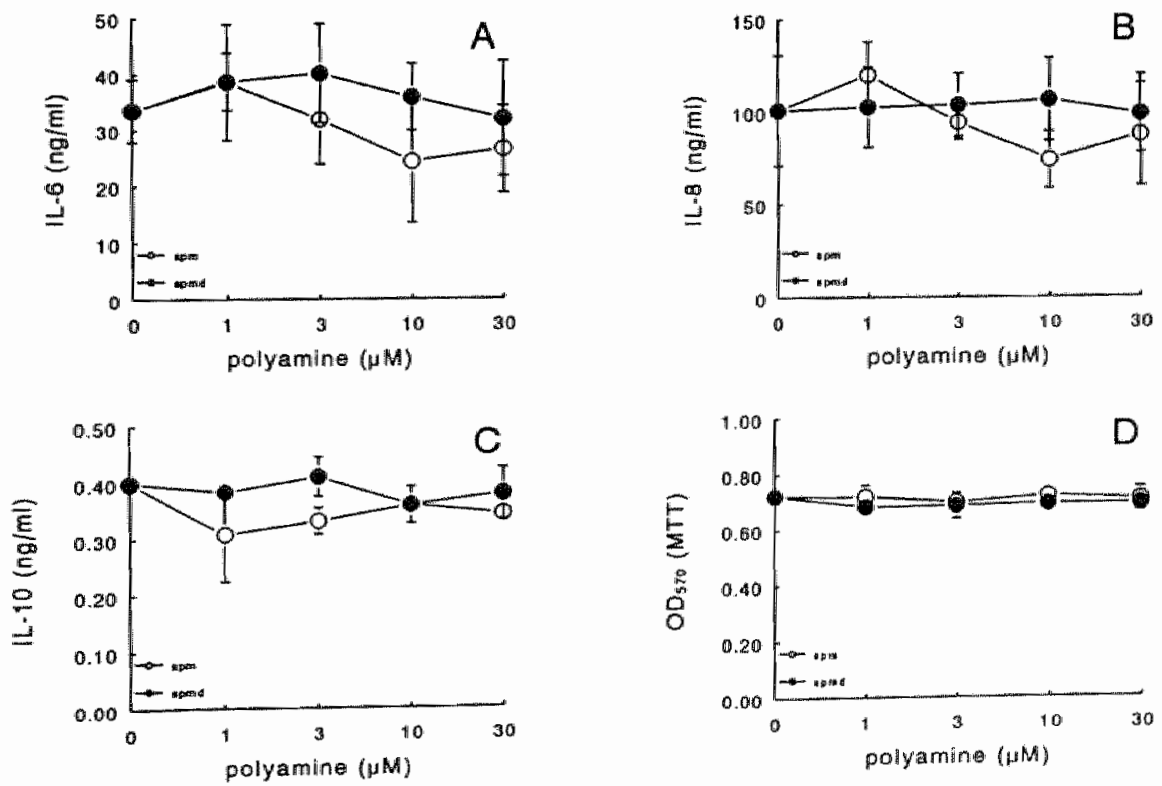


\section{Effects of polyamines in the absence of $\mathrm{PAO}$ activity}

In order to investigate whether PAO present in BCS used in the experiments played a role in the observed stimulatory as well as inhibitory effects of polyamines on cytokine release by PBMCs and monocytes, BCS was replaced by HS, which lacks PAO $(8,26)$. These experiments demonstrated that in HS, spermine and spermidine did neither affect basal cytokine production nor PHA-, LPS-induced cytokine release (Figure 5). Moreover, under these conditions spermine and spermidine did also not affect cell viability (Figure 5D). Further, similar to the results which were obtained with a 20 hours stimulation period, HS also abrogated the effects obtained using BCS during 4 hours incubation period (data not shown). Taken together, these data suggest that spermine and spermidine themselves are neither pro-inflammatory nor toxic for human PBMCs or monocytes but that polyamine oxidation in cultures with BCS leads to polyamine metabolites, which are pro-inflammatory at low concentrations and cytotoxic at higher concentrations.

In line with the results obtained using BCS as serum component, no effect on cell viability and cytokine production was observed when putrescine and cadaverine were added to the cells in presence of HS (data not shown). These results were anticipated since these diamines are not oxidized by $\operatorname{PAO}(4,33)$.

\section{Inhibition of PAO activity in BCS using PAO inhibitors}

To further investigate the hypothesis that oxidation products of spermine and spermidine are responsible for the observed effects of polyamines, the PAO inhibitors, isonicotonic acid hydrazide (IS) and hydroxylamine (HA) either alone or in combination were added to $\operatorname{BCS}(8,10,15)$. IS and HA were added to BCS and incubated for $15 \mathrm{~min}$ at $37^{\circ} \mathrm{C}$ before addition to the culture medium and cells.

Addition of IS alone resulted in a shift of the cytokine release curve to the right, for all four cytokines tested, in comparison with the curve using BCS alone (Figure 6). This accounts for the observation that concentrations of 3 and $10 \mu \mathrm{M}$ spermine still enhanced the PHA- and LPS-induced cytokine release, in contrast to the inhibition observed at these concentrations using BCS alone. In line with this, a higher concentration of spermine was needed for inhibition of cytokine release in comparison with BCS alone (Figure 6). Similar results were obtained for spermidine except that the increase in IL-8 production at low concentrations was inhibited (Figure 7). In parallel with the effect on cytokine production, it was shown that IS partly prevented spermine-induced cytotoxicity (Figure 6C) and completely prevented spermidine toxicity (Figure $7 \mathrm{C}$ ). Taken together, these results show that a decrease in cytokine release in coincides with a decrease in cell viability. 
Figure 6. Inhibition of $P A O$ activity present in BCS by a combination of IS and HA abrogates the effects of spermine on PHA-induced IL-6 (A) and $L L-8(B)$ release and cell viability (C). Either inhibitor alone only partly abolishes these effects. Cytokine levels and cell viability were determined after a 20 hours incubation period. Results are expressed as percentage of the cytokine cancentrations detected in the supernatants of corresponding control cultures incubated without spermine *: $p<0.05$ versus control. One representative experiment out of a total three is depicted.
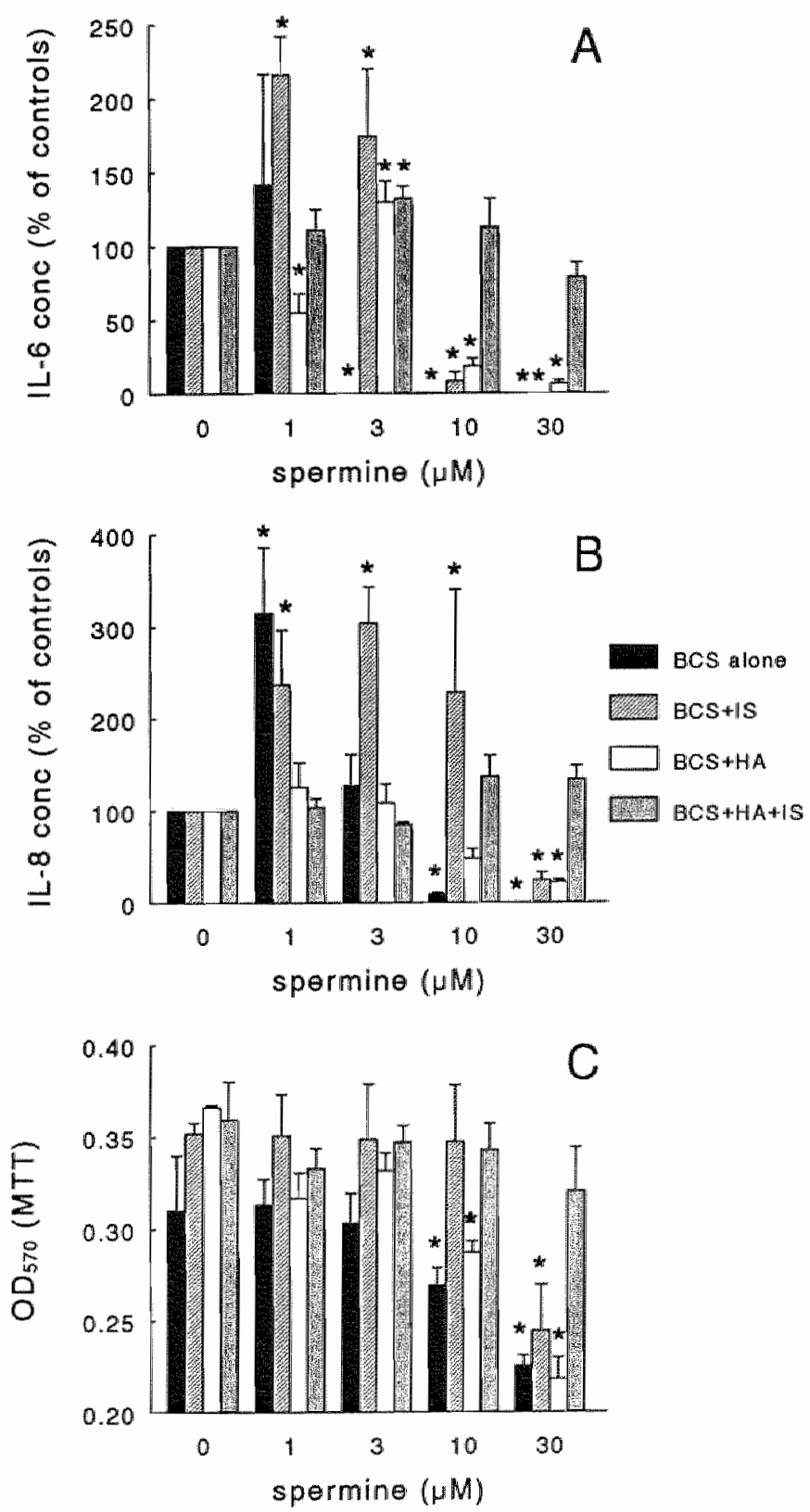
Figure 7. Inhibition of PAO present in BCS by IS and HA either alone or in combination abolish the effects of spermidine on PHA-induced IL-6 (A) and IL-8 (B) release and cytotoxicity (C). Results are expressed as percentage of the cytokine concentrations detected in the supernatants of corresponding control cultures incubated without spermidine *: $p<0.05$ versus control. One representative experiment out of a total three is depicted.
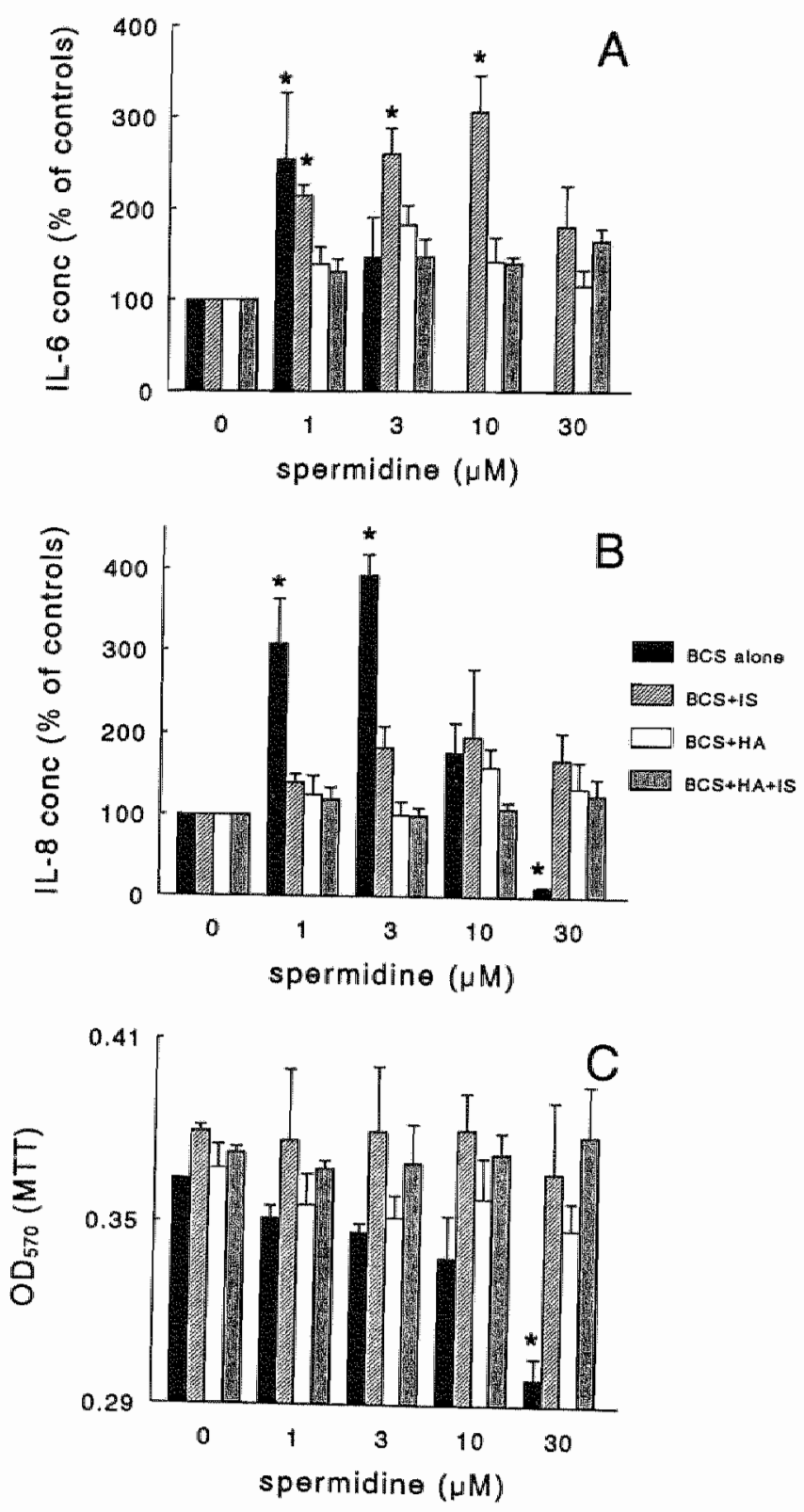
Addition of HA alone to BCS prevented, in contrast to IS addition, the proinflammatory effects of spermine (Figure 6) and spermidine (Figure 7) on cytokine release at low concentrations. Further, similarly to IS, HA addition partially prevented spermine-induced and completely prevented spermidine-induced cell death. The observed decrease in cytokine production at higher polyamine concentrations was paralleled by a decrease in cell viability.

In the presence of BCS the combination of both inhibitors completely prevented the pro-inflammatory and anti-inflammatory effects of polyamines as well as the decrease in cell viability (Figures 6 and 7). Therefore, these data suggest that the combination of both PAO inhibitors was necessary to completely block PAO activity. Further, these data support our hypothesis that polyamines are oxidized into metabolites which are pro-inflammatory at low concentrations and cytotoxic for human PBMCs and monocytes at higher concentrations and that inhibition of the release of cytokines by these cells is a result of cell death.

\section{DISCUSSION}

The data presented in this paper demonstrate that in the presence of PAO low concentrations of the polyamines spermine and spermidine $(<3 \mu \mathrm{M})$ exert proinflammatory properties, i.e. enhance $\mathbb{I L}-6, \mathbb{I L}-8$ and TNF- $\alpha$ release whereas higher concentrations $(>3 \mu \mathrm{M})$ of these polyamines inhibit the production of proinflammatory as well as anti-inflammatory cytokines by human PBMCs and monocytes. Furthermore, the inhibition of cytokine release is largely paralleled by a decrease in cell viability.

The results of our experiments using $\mathbb{H S}$, which in contrast to BCS lacks PAO activity $(8,26)$, indicate that polyamines themselves exhibit neither pro-inflammatory nor anti-inflammatory actions, but that these pro-inflammatory and anti-inflammatory effects result from products formed by PAO present in BCS $(8,15)$. To our knowledge this is the first report that demonstrates pro-inflammatory effects of polyamine oxidation products. This observation suggests that in the presence of PAO low concentrations of polyamines might act as stimulators of an inflammatory response by inducing the release of pro-inflammatory cytokines.

Our observation that polyamine oxidation products are toxic in high concentrations is supported by others $(8,11)$. In contrast, Byrd et al. (9) and Quan et al. (10) showed that the inhibitory effects of polyamines on the mitogen response of $\mathrm{T}$ cells is reversible, which argues against a cytotoxic effect. However, in our hands the immunosuppressive effect of polyamines could not be prevented by washing and restimulating the cells (data not shown). In line with our results, Flescher et al. (20) demonstrated that the inhibitory effect of spermine on IL-2 production was irreversible. 
To support our hypothesis that polyamine oxidation products are responsible for the observed effects, experiments were performed in BCS in combination with the PAO inhibitors IS and HA. Using these PAO inhibitors, we were able to confirm this hypothesis. Used simultaneously these inhibitors prevent polyamine-induced cytotoxicity paralleled by the absence of effect on PHA- and LPS-induced cytokine release, similar to the results obtained using HS, suggesting that PAO is inhibited completely when both IS and HA are used. The observation that inhibition of PAO activity abrogates the immunosuppressive effects of polyamines is confirmed by others $(8,15)$. Our results further show that in the presence of IS and $10 \mu \mathrm{M}$ spermine or spermidine $\mathbb{I I - 6}$ release is inhibited whereas $I L-8$ levels and cell viability are unaffected. This observation suggests that also non toxic immunosuppressive are formed and indicate that IL-6 production is more sensitive to these mediators than IL8 production.

Although the correlation between cell viability and cytokine production is clear, particularly after a 20 hours incubation period, this does not implicate that the inhibition of basal and LPS- or PHA-induced cytokine release is entirely due to cytotoxicity. Our results after a 4 hour incubation period show that addition of spermine to PBMCs or monocytes in the presence of BCS resulted in a complete inhibition of cytokine production and a substantial decrease in cell viability determined by the MTT assay. However, this decrease in cell viability was, in contrast to the inhibition of cytokine release, less pronounced than after a 20 hours incubation period. These results might indicate that possibly both immunosuppressive and cytotoxic products are formed after polyamine oxidation and that the cytotoxic effects develop slower.

The observed cytotoxicity might be due to formation of the known cytotoxic products ammonia and hydrogen peroxide which are byproducts of aldehyde formation $(19,21)$. The anti-inflammatory effects are ascribed to the formed aldehydes $(14,15,34)$. However, these aldehydes are very unstable and will spontaneously decompose in the cytotoxic product acrolein $(1,35)$. Two acrolein molecules will be formed when spermine is oxidized whereas after oxidation of spermidine only one acrolein molecule is generated (8). Therefore, the difference in effect of spermine and spermidine on cell viability and cytokine production suggests that acrolein production, rather than formation of polyamine aldehyde, hydrogen peroxide or ammonia, is responsible for the observed cytotoxic effects.

In line with earlier data our results indicate that putrescine and cadlaverine are not cytotoxic in the presence of PAO because similar results were obtained with either BCS or HS. Cadaverine and putrescine are no substrates for PAO $(4,33)$. However, the result of a study by Tabor et al. (4), who showed that putrescine is oxidized by diamine oxidase into an aldehyde, ammonia and hydrogen peroxide but without formation of acrolein, further support our hypothesis that ammonia and hydrogen peroxide are not responsible for the toxicity of spermine and spermidine, but that other 
products, such as acrolein with known toxic properties, are responsible for the observed toxicity.

Our data are supported by data of Zhang et al. (16), who showed that spermine inhibits the release of pro-inflammatory cytokines from human peripheral blood monocytes. In contrast to our results, however, they demonstrated that this effect was independent of PAO and unrelated to a decrease in cell viability. In this study we undoubtedly demonstrate that inhibition of cytokine release was paralleled by a decrease in cell viability and that using HS resulted in an abrogation of all effects on cytokine release and cell viability. This latter contradictory result might be explained by the fact that the serum Zhang et al (16) used contained PAO activity this in contrast to our HS. In normal HS no PAO activity is detectable. In contrast, however, PAO levels are clearly present in serum from pregnant women or infected individuals $(5,36,37)$. Also activated macrophages posses $\mathrm{PAO}$ activity, and can release $\mathrm{PAO}$ in the culture by incubation with LPS $(33,38,39)$. However, our results obtained with HS showed no effect of polyamines on basal or LPS- and PHA-induced cytokine production and cell viability indicating that $\mathrm{PAO}$ released by monocytes is not involved in the observed pro- and anti-inflammatory effects of polyamines in the model used.

In conclusion, our results demonstrate that polyamines themselves, exhibit neither anti-inflammatory nor cytotoxic actions on human PBMCs and monocytes. Oxidation of the polyamines spermine and spermidine by PAO results in the formation of products which exert pro-inflammatory effects when polyamines are present in low concentrations and have cytotoxic effects on PBMCs and monocytes when higher concentrations of polyamines are used.

\section{Acknowledgements}

This work was supported by a grant (1997-E5) from the Nutricia Research Foundation, The Hague, the Netherlands. The authors thank G. Francot for excellent assistance with the stimulation experiments.

\section{REFERENCES}

1. Pegg AE, Poulin $\mathbb{R}$, Coward $\mathbb{K}$. Use of aminopropyltransferase inhibitors and of nonmetabolizable analogs to study polyamine regulation and function. Int I Biochem Cell Biol 27 : 425-442, 1995.

2. Pegg AE. Polyamine metabolism and its importance in neoplasic growh and as target for chemotherapy. Cancer Res 48: 759-774, 1988.

3. Tabor CW, Tabor H. Polyanines. Ann Rev Biochem 53: 749-790, 1984

4. Tabor $H$, Tabor $C W$. Biosynthesis and metabolism of 1,4-dianjinobutane, spermidine and spermine, and related amines. Advan Enzymol 36:203-267, 1972

5. Morgan DM, Illei G. Polyamine-polyamine oxidase interaction: Part of maternal protective mechanism against fetal rejection. $\mathrm{Br}$ Med J280: 1295-1297, 1980. 
6. Morgan DM. Polyamines. Essoys Biochem 23: 82-115, 1987.

7. Ferrante A, Maxwell GM, Rencis VO, Allison AC. Morgan DML. Inhibition of the respiratory burst of human neutrophils by the polyamine oxidase-polyamine system. Int I Immunopharmacol 8: $411-417,1986$.

8. Labib RS, Tomasi TB. Enzymatic oxication of polyamines. Relationship to immunosuppressive properties. Eur I Immunol 11: 266-269, 1981.

9. Byrd WJ, Jacobs DM, Amoss MS, Synthetic polyamines added to cultures containing bovine sera reversibly inhibit in vitro parameters of immunity. Nature 267:621-623, 1977.

10. Quan CP, Roux C, Pillot I, Bouvet JP. Delineation between T and B suppressive molecules from human seminal plasma: II. Spermine is the major suppressor of T-lymphocytes in vitro. Am $J$ Reprod Immunol 22: 64-69, 1990.

11. Vliagoftis $\mathrm{H}_{\text {, Boucher } W S}$, Mak LL, Theoharides TC. Inhibition of mast cell secretion by oxidation products of natural polyamines. Biochem Pharmacol 43: 2237-2245, 1992.

12. Ogata K, Nishimoto $N$, Uhlinger DJ, Igarashi $K$, Takeshita $M$, Tamura $M$. Spermine suppresses the activation of human neutrophil NADPH oxidase in cell-free and semi-recombinant systens. Biochem J 313: 549-554, 1996.

13. Szabó C, Southan GJ, Wood E, Thiemermann C, Vane JR. Inhibition by spermine of the induction of nitric oxide synthase in $\mathbf{7 7 7 4 . 2}$ macrophages: Requirement of a serum factor. $\mathrm{Br} J \mathrm{Pharmacol}$ 112: $355-356,1994$.

14. Southan GJ, Szabó C. Thiemermann C. Inhibition of the induction of nitric oxide synthase by spermine is modulated by aldehyde dehydrogenase. Biochem Biophys Res Comm 203: 1638-1644, 1994.

15. Szabó C, Southan GJ, Thiemermann C, Vane IR. The mechanism of the inhibitory effect of polyamines on the induction of nitric oxide synthase: Role of aldehyde metabolites. $B r I$ Phawnacol 113: 757-766, 1994.

16. Zhang $M$, Caragine $T$, Wang $H$, Cohen PS, Botchkina $G$, Soda $K$, Bianchi M, Ulrich P, Cerami A, Sherry B, Tracey $\mathrm{KJ}$. Spermine inhibits proinflammatory cytokine synthesis in human mononuclear cells: A counterregulatory mechanisun that restrains the immune response. $f$ Exp Med 185: 1759-1768, 1997.

17. Wang H, Zhang M, Soda K, Sama A, Tracey KJ. Fetuin protects the fetus from TNF. Lancet 350 : $861.862,1997$.

18. Flescher E, Bowlin TL, Ballester A, Houk R, Talal N. Increased polyamines may downregulate interleukin-2 production in rhematoid arthritis. J Clin Invest 83:1356-1362, 1989.

19. Flescher E, Bowlin TL. Talal N. Regulation of IL-2 production by mononuclear cells from rheumatoid arthritis synovial fluids. Clin Exp immunol 87: 435-437, 1992.

20. Flescher E, Bowlin TL, Talal N. Polyamine oxidation down-regulates II-2 production by human peripheral blood mononuclear cells. J Immunol 142: 907-912, 1989.

21. Flescher E, Fossum D, Talal N. Polyamine-dependent production of lymphocytotoxic levels of anumonia by human peripheral blood monocytes. Immunol Lett 28: 85-89, 1991 .

22. Brtunton $\mathrm{VG}$, Grant $\mathrm{MH}$, Wallace HM. 1990. Spermine toxicity and glutathione depletion in BHK-21/C13 cells. Biochem Pharmac 40: 1893-1900.

23. Brunton VG, Grant MH, Wallace HM. 1991. Mechanisms of spermine toxicity in baby-hamster kidney (BHK) cells. Biochem $J$ 280: 193-198.

24. He Y, Kashiwagi $K$, Fukuchi J, Terao $K$, Shirahata A, Igarashi K. 1993 . Correlation between the inhibition of cell growth by accumulation of polyamines and decrease of magnesium and ATP. Eur J Brochem 217: 89-96.

25. Mitchell JLA, Dively RR, Bareyal-Leyser A. Mitchell $\pi$. 1992. Abnormal accumulation and toxicity of polyamines in a difluoromethylomithine-resistant HTC cell variant. Biochem Biophys
Acta $1136: 136-142$. 
26. Ebong $\mathrm{S}$, Farkas WR. Absence of plasma amine oxidase in some frequently used animal models. Comp Biochem Physiol 106C: 483-487, 1993.

27. Graziano RF, Fanger MW. 1987. FcyRI and FcyRll on monocytes and granulocytes are cytotoxic trigger molecules for tumor cells. I Immunol 139:3536-3541, 1987

28. Engelberts I, Möller A, Schoen GMM, Van der Linden $\mathrm{CJ}$, Bumman WA. Evaluation of measurement of human TNF in plasma by ELISA. Lymphokine Cytokine Res 10: 69-76, 1991.

29. Dentener MA, Bażil V, Von Asmuth ENU, Ceska M, Burman WA. Involvement of CD14 in lipopolysaccharide-induced tumor necrosis factor- $\alpha$, IL -6 and IL-8 release by human monocytes and alveolar macrophages. $J$ Immunol $150: 2885-2891,1993$.

30. Bouma MG, Stad RK, Van den Wildenberg FAJM, Buurman WA. Differential regulatory effects of adenosine on cytokine release by activated human monocytes. I Immunol 153:4159.4168, 1994.

31. Abrams JS, Roncarolo MG, Yssel H, Andersson U, Gleich Gi, Silver JE. Strategies of anticytokine monoclonal antibody development: Immunoassay of $\mathbb{L}-10$ and IL-5 in clinical samples. Immanol Rev 127: 5-24, 1992.

32. Hanssen MB, Nielsen SE, Berg $\mathbb{K}$. Re-examination and further development of a precise rapid dye method for measuring cell growth/ cell kill. I Immunol Methods 119:203-210, 1989.

33. Seiler $N$, Moulinoux IP, Havouis $\mathbb{R}$, Toujas L. Characterization of amine oxidase activities in macrophages from human peripheral blood. Biochem Cell Biol 73: 275-281, 1995.

34. Wang E, Mason Conant $J, L i D$, Visconti $V$, Chourmouzis E, Lan C. Ex vivo Spermine dialdelyyde treatment prevents lethal GVHD in a murine bone marrow transplantation model. Bone Marrow Trakspl 6: 235-242, 1990.

35. Morgan DLM. Polyamine oxidase and oxidized polyamines. In The physiology of Polyamines. Bachrach U and Heimer YM (Eds.), CRC Press, Boca Raton, pp. 203-229, 1989.

36. Morgan DML, Christensen JR. Polyamine oxidation and the killing of intracellular parasites. Biochem Soc Trans 9: 563-564, 1993.

37. Morgan DML. Human pregnancy-associated polyamine oxidase- partial purification and properties. Biochem Sac Trans 13: 351-352, 1985.

38. Smith CJ, Maschler R, Maurer HR, Allen JC. Inhibition of cells in culture by polyamines does not depend on the presence of ruminant senum. Cell Tissue Kinet 16:269-276, 1983

39. Morgan DML, Fergluga J, Allison AC. Polyamine oxidase and macrophage function. In Polyamine in Biomedical Research. MM Gauges (Ed.), John Wiley \& Sons, Chichester, pp. 303. 1980. 
$-160-$ 


\section{CHAPTER 9}

ORAL SPERMINE ADMINISTRATION INHIBITS NO-MEDIATED INTESTINAL DAMAGE AND LEVELS OF SYSTEMIC INFLAMMATORY MEDIATORS IN A MOUSE ENDOTOXIN MODEL

Ter Steege JCA, Forget PPh, and Buurman WA. Shock, in press 


\section{ABSTRACT}

Enhanced intestinal $\mathrm{NO}$ production observed during sepsis is thought to play a central role in LPS-induced intestinal damage. In contrast intestinal polyamines, both from endogenous and exogenous origin, are essential for the maintenance of mucosal integrity. Polyamines have been shown to inhibit LPS-induced NO release in vitro and have been claimed to exert additional anti-inflammatory actions. In this study, the effect of the polyamine spermine on the release of the pro-inflammatory mediators $\mathrm{NO}$ and TNF $\alpha$ by RAW cells was investigated. Furthermore, we investigated whether oral spermine administration inhibits LPS-induced intestinal iNOS and nitrotyrosine expression and modullates the systemic inflammatory response. Our results show that whereas spermine inhibited LPS-induced NO release in RAW cells, no effect on TNF$\alpha$ rellease was observed. In addition, oral spermine administration inhibited intestinal INOS and nitrotyrosine expression suggesting a protective effect of spermine on LPSinduced intestinal damage. In parallel a decrease in serum levels of the proinflammatory mediators $\mathrm{NO}_{\mathrm{x}}$ and IFN- $\gamma$ and an increase in the anti-inflammatory cytokine $1 L-10$ was observed, whereas $T N F-\alpha$ levels were unaffected. These results indicate that spermine inhibits LPS-induced $\mathrm{NO}$ release in vitro as well as in wivo. Further, intraluminally derived polyamines modulate the systemic immune response. It is concluded that oral spermine administration might have therapeutic perspectives for several disorders characterized by systemic inflammation and intestinal damage.

\section{INTRODUCTION}

The gastrointestinal tract is increasingly being recognized as an important organ in the pathogenesis of sepsis, as mucosal barrier dysfunction, which is often associated with this condition, is considered to play a role in the development of multiple organ failure $(1,2)$. Sepsis is characterized by the release of various pro-inflammatory mediators such as TNF- $\alpha$, IFN- $\gamma$, and nitric oxide (NO), which all are involved in endotoxin induced lethality (3-6). Ellevated levels of $\mathrm{NO}$ have been implicated to play a central role in the development of intestinal damage as observed during sepsis. NO is known to enhance intestinal damage and permeability, probably via its reaction with superoxide resulting in the formation of the aggressive oxidant peroxynitrite (7). A known reaction product of peroxynitrite oxidation is nitrotyrosine, the stable endproduct from the reaction of peroxynitrite with tyrosine. Nitrotyrosine can be detected immunohistochemically and has been used as a indicator of NO-mediated tissue damage (8).

Szabo and colleagues have recently demonstrated that the polyamine spermine inhibits LPS-induced NO release in the murine macrophage cell line 3774.2 , indicating that polyamines affect $\mathrm{NO}$ release $(9,10)$. A wide variety of other immunosuppressive actions of polyamines have been reported in vitro $(11-13)$, 
although there is controversy about the issue whether this effect is mediated by the polyamines themselves or by their oxidation products and whether these are due to cytotoxicity or not. Moreover, intraluminal derived polyamines, i.e. polyamines produced by bacterial flora or derived from the diet, have been shown to modulate the physiological immune response in vivo (14).

In contrast to $\mathrm{NO}$, polyamines are essential for the maintenance of mucosal integrity. This is illustrated by the fact that inhibition of intestinal polyamine synthesis causes severe intestinal damage whereas enhanced intestinal concentrations of polyamines stimulate intestinal repair (15-18). Intestinal ornithine decarboxylase (ODC) activity, the rate limiting enzyme in polyamine biosynthesis and polyamine biosynthesis are increased during endotoxemia, suggesting a requirement for intestinal polyamines in this condition $(19,20)$. Furthermore, urinary excretion of polyamine degradation products is increased in septic patients (21), indicating enhanced utilization of polyamines which supports the hypothesis of increased requirement for polyamines during sepsis.

In this study we investigated the effect of spermine on LPS-induced release of the pro-inflammatory mediators NO and TNF- $\alpha$ by the murine macrophage cell line RAW 267.4. Furthermore, in view of the reciprocal and important role that NO and polyamines play in the maintenance of mucosal integrity including the described antiinflammatory properties of the latter, we hypothesized that polyamine administration could inhibit LPS-induced intestinal damage and reduce the release of inflammatory mediators. Therefore, the effect of oral spermine administration during 3 days before LPS challenge in mice on LPS-induced intestinal NO production and inflammation was investigated by immunohistochemical staining of intestinal tissue for iNOS, nitrotyrosine, macrophages and neutrophils. In parallel the effects on serum levels of pro-inflammatory mediators such as $\mathrm{NO}_{\mathrm{x}}, \mathrm{IFN}-\gamma, \mathrm{TNF}-\alpha$, and the anti-inflammatory mediator IL-10 levels were analyzed.

\section{MATERIALS AND METHODS}

\section{Reagents}

Spermine, lipopolysaccharide (LPS) E.coli OB55:B5, bovine serum albumin (BSA), hematoxylin solution and 3-amino-9-ethylcarbazole (AEC) were obtained from Sigma (St Louis, MO); sulfuric acid was from Merck (Darmstadt, Germany). Tissue culture plates were from Costar (Cambridge, MA). RPMI 1640, penicillin, streptomycin and glutamine were obtained from Gibco BRL (Gaithersburg, MD). NADPH, nitrate reductase, 3,3',5,5'-tetramethylbenzidine (TMB), digoxigenin (DIG) and peroxidase labeled anti-DIG Fab fragments were obtained from Boehringer Mannheim (Mannheim, Germany). Monoclonal anti-neutrophil antibody Gr-1 was obtained from Pharmingen (San Diego, CA). Polyclonal rabbit anti-murine TNF and anti-murine 
IL-10 antibodies were produced by injecting rabbits with recombinant murine TNF $(\mathrm{mTNF}-\alpha)$ and murine $\mathrm{IL}-10$ (rmL-10), respectively. Goat anti-rabbit-peroxidase was obtained from Jackson ImmunoResearch (Westgrove, PA). The following agents were obtained through the courtesy of the following persons or companies: rmTNF by $\mathrm{BASF} / \mathrm{Knoll}$ (Ludwigshafen, Germany); 2A5, the rat anti-murine IL-10 monoclonal antibodly, the mouse IFN- $\gamma$ ELISA and rat IFN- $\gamma$ by Hbt (Uden, the Netherlands); rmIL-10 by Dr. R. de Waal Malefyt (DNAX, Palo Alto, CA); rabbit anti-murine iNOS antiserum from Dr. J. Cohen (Infectious Disease Unit, Royal Postgraduate Medical School, London, UK) (22) and rat anti-murine macrophage marker F4/80 supernatant from Dr. P. Leenen (Dept. of Immunology, Erasmus University Rotterdam, the Netherlands) (23).

\section{Stimulation of RAW 2644.7 cells}

RAW 264.7 cells, a murine macrophage cell line, were cultured in RPMI containing $10 \% \mathrm{BCS}, 100 \mathrm{U} / \mathrm{ml}$ penicillin, $100 \mu \mathrm{g} / \mathrm{ml}$ streptomycin and $2 \mathrm{mM}$ glutamine. Cells were plated in a 96 -wells plate at $5^{*} 10^{4}$ cells/well the day before stimulation. One hour before stimulation the cells were incubated with different concentrations of spermine $(0-30 \mu \mathrm{M})$. Cells were stimulated with rat IFN- $\gamma(100 \mathrm{U} / \mathrm{ml})$ and LPS $(1$ $\mu \mathrm{g} / \mathrm{ml})$ for 20 hours. Nitrite and TNF- $\alpha$ levels in the supernatants were determined as described below. Experiments were performed in quadruplicate.

\section{Animals}

Female Swiss mice of 2-6 months of age were obtained from Charles River Breeding Laboratories (Heidelberg, Germany), maintained on standard laboratory diet and allowed free access to water. Guidelines of the Committee for Care and Use of Laboratory Animals from the Maastricht University were followed throughout.

\section{Experimental protocol}

Mice received either PBS (Group 2, $n=5$ ) or $0.25 \mu \mathrm{mol} / \mathrm{gram}$ body weight spermine (Group 3, $n=5$ ) orally twice a day during three days before an intraperitoneal LPS injection $(250 \mu \mathrm{g}$ in $0.5 \mathrm{ml}$ PBS). Results were compared with a group of non-treated mice receiving an intraperitoneal injection with PBS (Group 1, $n=5$ ). Six hours after LPS injection, blood was sampled by orbital punction after which the mice were sacrificed by cervical dislocation. The small intestine was collected and immediately frozen in liquid nitrogen. 


\section{Immunohistochemistry}

Frozen tissue sections $(5 \mu \mathrm{m})$ were fixed in acetone and air dried. Endogenous peroxidase was blocked by immersing the slides in $0.03 \%$ hydrogen peroxidase in PBS for $30 \mathrm{~min}$, followed by washing in PBS (three washes, 5 min each). After blocking nonspecific binding with $5 \% \mathrm{BSA}$ for $30 \mathrm{~min}$, sections were incubated for hour with either rabbit anti-iNOS antiserum or with normal rabbit serum (negative controly diluted in PBS containing $0.1 \% \mathrm{BSA}$ and $2 \%$ normal mouse serum. Next, the sections were washed with PBS and incubated for 1 hour with biotin labeled goat antiserum to rabbit $\operatorname{IgG}$ and subsequently incubated for $45 \mathrm{~min}$ with freshly prepared avidin-biotin-peroxidase. Peroxidase activity was detected using $\mathrm{AEC}$ as substrate. Sections were counterstained with hematoxylin.

The same histologicall method was used to stain for macrophages (F4/80, culture medium), and neutrophils (Gr-1,5 $\mathrm{g} / \mathrm{ml}$ ) except that a peroxidase labeled goat antirat was used as secondary antibody. For nitrotyrosine staining a newly developed DIG-labeled murine anti-nitrotyrosine monoclonal antibody, designated HM. 11 was used (manuscript submitted). Peroxidase conjugated goat anti-DlG was used as secondary antibody.

\section{Histological analysis}

Intensity of staining and number of cells positive for NOS, nitrotyrosine, macrophage and neutrophil markers were sconed semi-quantitatively by two independent observers which were blinded to the specific treatment of the animals.

\section{Determination of $\mathrm{NO}_{\mathrm{X}}$ (nitrite and nitrate) levels}

After reducing nitrate to nitrite with bacterial nitrate reductase, serum nitrite llevels were measured as indicator of NO synthesis, using a microplate assay method, based on the Griess reaction (24). In shor, $30 \mu$ of experimental serum, $10 \mu \mathrm{I}$ NADPH $(0.75$ $\mathrm{U} / \mathrm{ml}$ ) and $10 \mu \mathrm{l}$ nitrate reductase $(0.5 \mathrm{U} / \mathrm{ml})$ were incubated in a 96 well microplate for 20 min at room temperature (RT). Next, $50 \mu$ Griess reagent, which consists of one part $0.1 \% \mathrm{~N}$-(1-naphthyl)-ethylenediamine dihydrochloride in distilled water and one part $1 \%$ sulfanilamide in $5 \%$ concentrated $\mathrm{H}_{3} \mathrm{PO}_{4}$, was added and incubated for 10 min at RT. The optical density was determined at $540 \mathrm{~nm}$ using a microwell plate reader. The amount of nitrite was calculated from a $\mathrm{NaNO}_{2}$ standard curve prepared in control serum.

\section{ELISA for murine IFN- $\gamma$}

Serum IFN- $\gamma$ levels were determined using a mouse IFN- $\gamma$ ELISA kit kindly provided by Hbt (Uden, the Netherlands) according to the manufacturers instruction. 


\section{ELISA for murine TNF}

ELISA for murine TNF was performed as described earlier by Dentener $e$ al. (25). A hamster anti-murine monoclonal (TN3) was used as capture antibody and a polyclonal rabbit anti-murine TNF as secondary antibody. The ELISA has a lower detection limit of $50 \mathrm{pg} / \mathrm{ml}$.

\section{ELISA for murine IL-10}

The rat anti-murine monoclonal $2 \mathrm{~A} 5$ was used as capture antibody. Serum samples were diluted 10 times and correlated to a standard titration curve of $\mathrm{rmL}-10$. An incubation with polyclonal rabbit anti-murine IL-10 was followed by an incubation with peroxidase labeled goat anti-rabbit antibody. TMB was used as substrate and optical density was read by $450 \mathrm{~nm}$. The ELISA had a lower detection limit of 160 $\mathrm{pg} / \mathrm{ml}$.

\section{Statistical analysis}

The differences between the three experimental groups were analyzed by a one-way analysis of variance, followed by Bonferroni's t-test, when overall variation was significant. Differences were considered statistically significant at $p<0.05$.

\section{RESULTS}

\section{Effect of spermine on LPS-induced NO and TNF- $\alpha$ release by RAW cells}

To investigate whether spermine inhibits LPS-induced NO and TNF- $\alpha$ release, RAW cells were preincubated with different concentrations of spermine one hour before LPS challenge. Spermine inhibited LPS-induced NO release in a dose dependent manner, resulting in a significant reduction with $10 \mu \mathrm{M}$ and $30 \mu \mathrm{M}$ spermine (Figure IA). In contrast, no effect of spermine on the production of TNF- $\alpha$ was observed (Figure 1B), indicating that inhibition of NO release by spermine is not mediated by TNE $\sim \alpha$.

\section{Effect of spermine administration on iNOS and nitrotyrosine expression}

LPS challenge induced intestinal iNOS (Figure 2A) and nitrotyrosine (Figure 2C) expression, indicating the presence of enhanced intestinal $\mathrm{NO}$ production and $\mathrm{NO}$ induced intestinal damage. Inducible NOS and nitrotyrosine expression were both detected in the crypt epithelium and in cells in the lamina propria. Oral spermine 
administration clearly inhibited LPS-induced iNOS (Figure 2B) and nitrotyrosine (Figure 2D) expression as compared to PBS-pretreated mice (Table 1).

Figure 1. Spermine inhibits LPS-induced NO release in a concentration dependen manner (A), whereas is does not affect TNF-a release (B). Data are expressed as mean + SD of four determinations. The resuls of one representative experiment out of four are depicted. : $p<$ 0.05 versus cells stimulated without spermine.
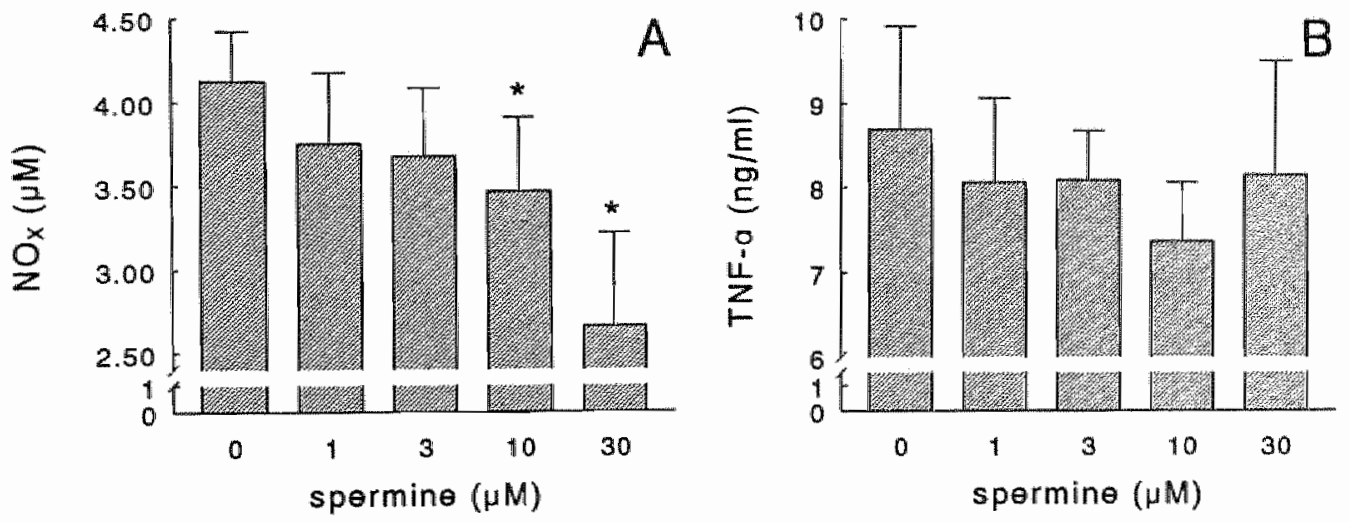

Table 1. Spermine administration inhibits the LPS-induced intestinal inflammatory response"

\begin{tabular}{llcc} 
& \multicolumn{2}{c}{ pretreatment } \\
\hline Intestinal changes & PBS & +++ & + \\
& nitrotyrosine & +++ & + \pm \\
& neutrophils & ++ & + \\
& macrophages & ++ & + \\
\hline
\end{tabular}

"Intensity of immunohistological staining and the number of positive cells were scored semiquantitatively by two independent observers, which were blinded to the specific treatment of the animals and is presented as relative value as compared with non-treated control mice (Group 1). 
Figure 2. LPS-induced WOS (A) and nitrotyrosine (C) expression is detected in the crypt epithelium and in infiltrating cells in the lamina propria, 6 hours after LPS challenge. Oral spermine adminisiration before LPS injection inhibits intestinal iNOS $(B)$ and nitrotyrosine (D) expression. Original magnification $200 x$.
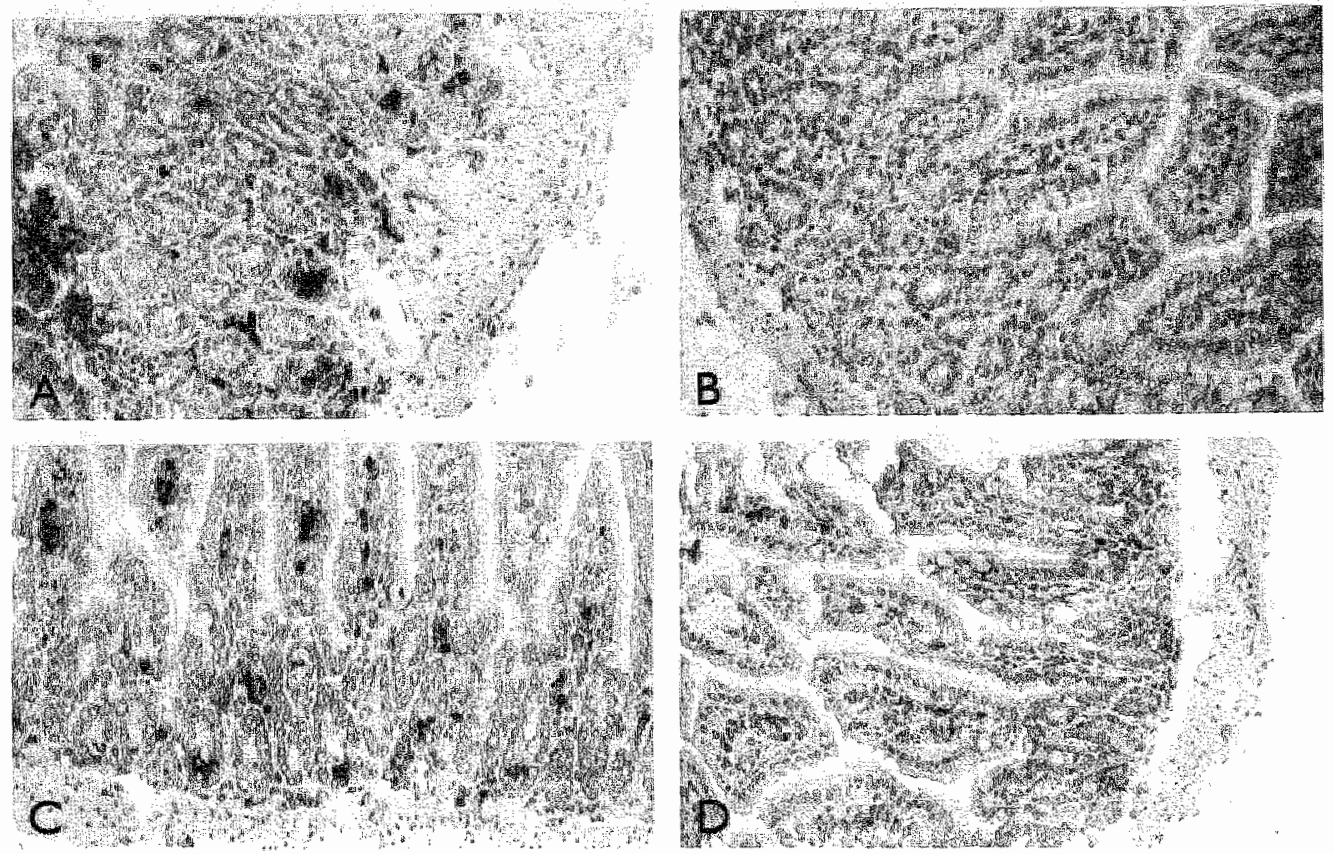

\section{Effect of spermine administration on intestinal macrophages and neutrophils infiltration}

In the intestine of non-treated control mice animals numerous residing macrophages were observed, whereas only a few cells staining with the neutrophil marker Gr-1 were noticed. The number of macrophages as well as neutrophils increased after LPS challenge, indicating intestinal infiltration by these cells. Oral spermine administration reduced the influx of both macrophages and neutrophils (Table 1).

\section{Effect of spermine administration on serum levels of $\mathrm{NO}_{x}$, IFN- $\gamma$, TNF- $\alpha$, and IL-10}

We have recently demonstrated that serum levels of $N_{x}$, IFN- $\gamma$, and TNF- $\alpha$ were significantly elevated, six hours after LPS challenge in mice (3). As depicted in Figure $3 \mathrm{~A}$, oral administration of spermine moderately but significantly inhibited LPSinduced serum $\mathrm{NO}_{x}$ levels. As we have shown previously, LPS-induced NO release is 
mediated through elevated production of IFN- $\gamma$ and TNF $-\alpha$ (3). Therefore, the effect of oral spermine administration on LPS-induced serum IFN- $\gamma$ and TNF- $\alpha$ levels was also investigated. Oral spermine administration significantly inhibited LPS-induced IFN- $\gamma$ levels (Figure 3B) while lacking effect on TNF- $\alpha$ levels (Figure 3C).

In addition, we investigated the effect of spermine administration on serum levels of the anti-inflammatory cytokine IL-1.0 which plays a role in the counterregulation of the pro-inflammatory response induced by LPS injection. Our results demonstrate that IL-10 levels were slightly increased after LPS challenge and that oral spermine administration significantly enhanced LPS-induced IL-10 serum levels (Figure 3D). Together, these data suggest that oral spermine administration inhibits LPS-induced NO release and modulates the release of the inflammatory mediators by inhibition of the pro-inflammatory mediator IFN- $\gamma$ and enhancing the release of the antiinflammatory mediator IL-10.

Figure 3. Oral spermine administration inhibits LPS-induced serum $N O_{x}(A)$ and IFN- $\gamma(B)$ levels, enhances $I L-10(D)$ and does not affect $T N F \sim \alpha$ (C) levels, 6 hours after $L P S$ challenge. Data are expressed as mean $+S D$. Group 1: non-treated control animals; group 2: PBS pretreated, LPS challenged animals; group 3: spermine preireated, LPS challenged animals. *: $p<0.05$ versus Group 1, \#: $p<0.05$ versus Group 2.
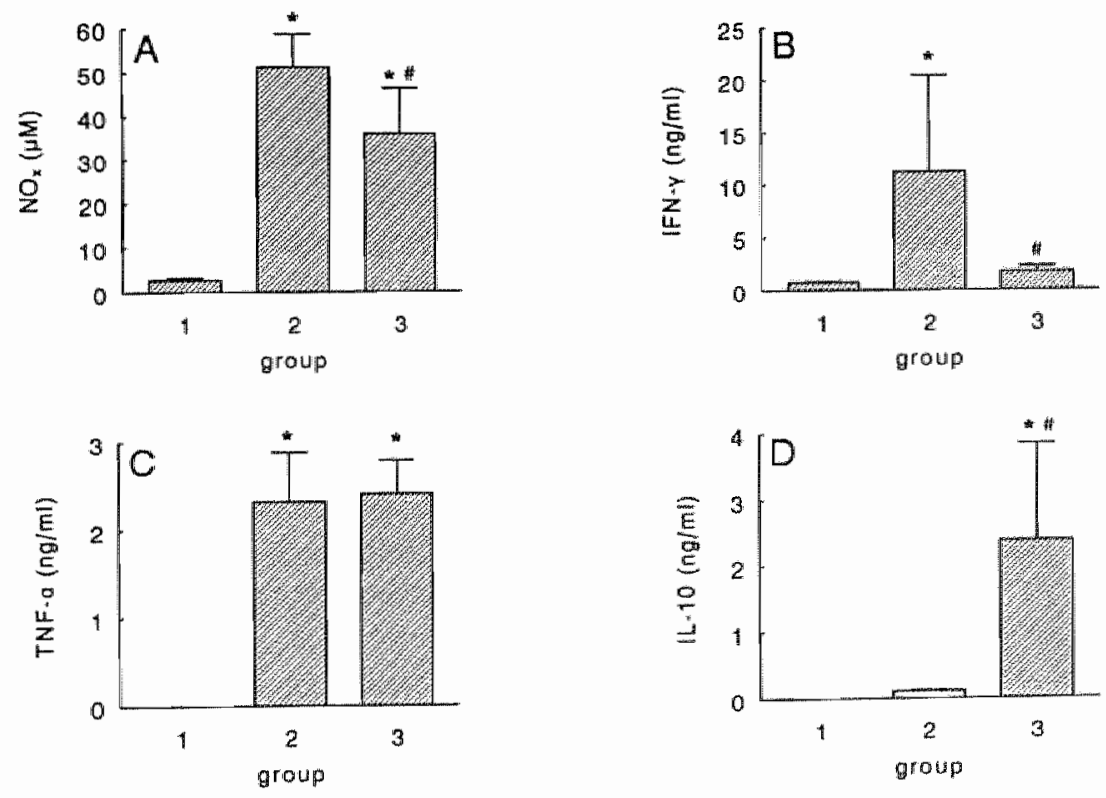


\section{DISCUSSION}

In this study we show that spermine specifically inhibits LPS-induced NO release in vitro without affecting TNF- $\alpha$ release. Moreover, it is demonstrated that oral spermine administration inhibits LPS-induced intestinal NO production and suppresses the release of the production of the pro-inflammatory mediators $N O$ and $I F N-\gamma$ and increases the synthesis of the anti-inflammatory cytokine IL-10.

Our results showing that spermine specifically inhibits NO production without affecting TNF- $\alpha$ release in a murine macrophage cell line suggest a direct effect of spermine on NO production without an inhibitory effect on TNF- $\alpha$ as intermediate in NO downregulation. Although in contrast with results of Wang and coworkers (26), who found an inhibitory effect of spermine on LPS-induced TNF- $\alpha$ rellease by RAW cells, our results are supported by those of Szabó et al. (10) who demonstrated that spermine inhibits LPS-induced NO release without affecting TNF- $\alpha$ production.

In line with other studies (27, manuscript in preparation), intestinal iNOS expression is upregulated, six hours after LPS challenge. In this study, we demonstrate that enhanced iNOS expression is parallelled by increased nitrotyrosine expression. Both iNOS and nitrotyrosine staining were detected in the crypt epithelium and in cells present in the lamina propria. Oral spermine administration inhibits both LPSinduced intestinal $\mathrm{INOS}$ and nitrotyrosine expression. Although iNOS expression was almost completely inhibited, the effect on nitrotyrosine expression was less pronounced. This observation might suggest that although iNOS expression was undetectable by immunohistochemical staining, spermine did not entirely inhibit LPSinduced NO release. This hypothesis is supported by Miller ef al. (8) who showed that complete inhibition of NO production prevents nitrotyrosine formation, indicating that $\mathrm{NO}$ is essential for nitrotyrosine formation.

The role of $\mathrm{NO}$ in modulating systemic inflammatory responses is increasingly recognized $(6-8,28)$. Inhubition of $\mathrm{NO}$ synthesis, as was also observed in this study, has been shown to have beneficial effects in several endotoxemia models $(6,28)$. We have observed earlier that, in mice, the small intestine, lung and heart are the majot organs involved in NO production after LPS challenge and that NOS expression in these organs correlates well with serum $\mathrm{NO}_{x}$ levels $(3$, manuscript in preparation). The question whether the observed modest inhibition of serum $\mathrm{NO}_{\mathrm{X}}$ levels after oral spermine administration results from inhibition of intestinal $\mathrm{NO}$ production alone or may be the results of inhibition of NO production by other cells or organs as well, remains to be elucidated.

Oral spermine administration inhibited the LPS-induced influx of macrophages and neutrophils in the small intestine, which might be a direct effect of spemine on macrophage and neutrophil locomotion. In support of this hypothesis Ferrante et al. (29) have shown that spermine inhibits neutrophil locomotion in vitro. On the other hand, the inhibitory effect of spermine on cellular influx could be mediated by 
enhanced levels of IL-10, since we detected increased levels of IL-10, which has been shown to inhibit neutrophil and macrophage migration $(30,31)$.

In a previous study we have shown that whereas the pro-inflammatory cytokines IFN- $\gamma$ and TNF- $\alpha$ involved in the upregulation of NO release after LPS challenge, IL10 is involved in the downregulation of NO as well as TNF- $\alpha$ and IFN- $\gamma$ production (3). In this study we demonstrate that oral spermine administration inhibits serum $\mathrm{NO}_{x}$ and IFN- $\gamma$ and increases IL-10 levels. It could be speculated that spermine-induced increases in IL-10 are responsible for the observed inhibitory effects of spermine on NO and IFN- $\gamma$. However, spermine did not affect TNF $-\alpha$ production. The observation that inhibition of NO release by spermine is not associated by a decrease in TNF- $\alpha$ production, is confirmed by our in vitro data which suggest a direct effect of spermine on NO synthesis. It has been shown that polyamines can act directly on gene expression at both transcriptional as well as posttranslational levels (32).

Elevated levels of IFN- $\gamma$ have been shown to induce enhanced intestinal permeability. This effect of IFN- $\gamma$ is mediated by NO (33). Therefore, oral spermine administration might maintain intestinal integrity either by inhibition of LPS-induced IFN- $\gamma$ production or by direct inhibition of NO synthesis. In support of the latter, we have demonstrated that anti-IFN- $\gamma$ treatment alone does neither affect intestinal iNOS expression nor serum $\mathrm{NO}_{\mathrm{x}}$ levels ( 3 , manuscript in preparation). Although most of our observations suggest a direct effect of polyamines on cytokine release, it is of further interest to note that oral spermine administration has been shown to induce the release of corticosteroids which might indicate that the anti-inflammatory effects observed after oral spermine administration are at least partly mediated by the release of corticosteroids, which are known to induce IL-10 (34).

Experimental endotoxemia is characterized by intestinal damage and systemic inflammation. The question whether intestinal damage is responsible for the systemic inflammation or vice versa still remains unsolved. Whatever the answer, polyamines may interfere with the development of intestinal damage as well as systemic inflammation. On the one hand they can promote intestinal repair and therefore inhibit the inflammation and on the other hand they can suppress the systemic inflammatory response and thereby inhibit intestinal damage. Although most of our data suggest a direct effect of spermine on NO, IFN- $\gamma$ and Il-10 release, the exact mechanism by which oral spermine administration affects intestinal and systemic inflammation needs further investigation.

In short, this study demonstrates that spermine inhibits LPS-induced NO release in vitro as well as in vivo. Oral spermine administration inhibits LPS-induced iNOS and nitrotyrosine expression parallelled by inhibition of serum levels of the proinflammatory mediators IFN- $\gamma$ and $\mathrm{NO}_{\mathrm{X}}$ and an increase in serum levels of the antiinflammatory cytokine IL-10. Our data suggest that oral administration of polyamines, such as spermine, could present therapeutic perspectives in several clinical conditions that are characterized by systemic inflammation and intestinal damage. These therapeutic applications need to be evaluated in experimental animal studies. 


\section{Acknowledgement}

This work was supported by a grant (1997-E5) from the Nutricia Research Foundation, The Hague, the Netherlands.

\section{REFERENCES}

1. Antonsson JB, Fiddian-Green RG. The role of the gut in shock and multiple system organ failure. Eur J Surg 157: 3-12, 1991.

2. Wilmore $\mathrm{DW}$, Smith $\mathrm{R}$, ODwyer $\mathrm{ST}$, Jacobs DO, Zlegler TR, Wang XD. The gut: a centrall organ after surgical stress. Surgery 104: $917-923,1988$.

3. Ter Steege JCA, Van de Ven WCM, Forget PPh, Brouckaert P, Burman WA. The role of endogenous IFN- $\gamma$. TNF- $\alpha$ and IL-10 in LPS-induced nitric oxide release in a mouse model. Cytakine 10:115-123, 1998.

4. Gerard C, Bruyns C, Marchant A, Abramowicz D, Vandenabeele P, Delvaux A, Fires W, Goldman $M$, Velu $T$. Interleukin 10 reduces the release of tumor necrosis factor and prevents lethality in experimental endotoxemia. J Exp Med 177: 547-550, 1993.

5. Doherty GM, Lange JR, Langstein $\mathrm{HN}$, Alexander HR, Buresh $\mathrm{CM}$, Norton JA. Evidence for MFN$\gamma$ as a mediator of the lethality of endotoxin and tumor necrosis factor- $\alpha$. I Immunol 144: 16661670,1992

6. Vallance P, Moncada S. Role of endogenous nitric oxide in septic shock. New Horizons 1: 77-86, 1993.

7. Chamulitrat W, Skrepnik NV, Spitzer JJ. Endotoxin-induced oxidative stress in the rat small intestine: Role of nitric oxide. Shock $5: 217-222,1996$.

8. Miller MJS, Thompson JH, Zhang XJ, Sadowska-Krowicka H, Kakkis JL, Munshï UK, Sandoval M, Rossi JL, Eloby-Childress S, Beckman JS, Ye YZ, Rodi CP, Manning PT, Currie MG, Clark DA. Role of inducible nitric oxide synthase expression and peroxynitrite formation in guinea pig ileitis. Gastroenterology 109: 1475-1483, 1995.

9. Szabó C, Southan GJ, Wood E, Thiemermann C, Vane JR. Inhibition by spermine of the induction of nitric oxide synthase in 1774.2 macrophages: requirement of a serum factor. $B r J$ Pharmacol $112: 355-356,1994$.

10. Szabó $C$, Southan GJ, Thiemermann C, Vane JR. The mechanism of the inhibitory effect of polyamines on the induction of nitric oxide synthase: role of aldehyde metabolites $B r . J$ Phow macal 113: 757-766, 1994.

11. Labib RS. Tomasi TB. Enzymatic oxidation of polyamines. Relationship to imnunosuppressive properties. Eur J Immunol 11: 266-269, 1981.

12. Byrd WJ, Jacobs DM, Amoss MS. Synthetic polyamines added to cultures containing bovine sera reversibly inhibit in vitro parameters of immunity. Nature 267:621-623, 1977.

13. Flescher E, Bowlin TL, Ballester A, Flouk R, Talal $\mathbb{N}$. Increased polyamines may down-regulate interleukin 2 production in rheumatoid arthritis. J Clin Invest 83: 1356-1362, 1989.

14. Chamailiard L, Catros-Quemener V, Delcros JG, Bansard JY, Havouis R, Desury D, Commeurec A, Genetet N, Moulinonx. JP. Polyamine deprivation prevents the development of tumour-induced immune suppression. Br J Cancer 76:365-370, 1997.

15. Alarcon P. Lebenthal E. Lee PC. Effect of difluoromethyl ornithine (DFMO) on small intestine of adduit and weanling rats. Dig Dis Sci 32: 883-888, 1987. 
16. Luk GD, Baylin SB. Inhibition of intestinal epithelial DNA synthesis and adaptive hypenplasia after jejunectomy in rat by suppression of polyamine biosynthesis. I Chin Invest 74: 698-704, 1984.

17. Wang JW, McCormack SA, Viar MJ, Johnson LR. Stimulation of proximal small intestinal mucosal growth by himinal polyamines. Am J Physiol 261: G504-G511, 1991.

18. Dowling RH. Polyamines in intestinal adaptation and disease. Digestion 46 Suppl 2: $331-344$, 1990.

19. Endo $Y$. Simultaneous induction of histidine and omithine decarboxylases and changes in their product amines following the injection of Escherichia Coli lipopolysaccharide into mice. Biochem Pharmacal 31 : 1643-7.

20. Noguchi $Y$, Meyer TA, Tiao G, Ogle CK, Fischer JE, Hasselgren PO. Influence of sepsis and endotoxemia on polyamine metabolism in mucosa of small intestine in rats. Metabolism 45:28$33,1996$.

21. Poyhonen MJ, Takala JA, Pitkanen O, Kari A, Alakuijala LA, Eloranta TO. Urinary excretion of polyamines in patients with surgical and accidental trauma: effect of total parental mutrition. Metabolism 42: 44-51, 1980 .

22. Buttery LDK. Evans TJ, Springdall DR, Carpenter A, Cohen J, Polak IM. Immunohistochemical. localization of inducible nitric oxide synthase in endotoxin-treated rats. Lab Invest $71: 755-764$, 1994.

23. Austyn JM, Gordon S. F4/80, a monoclonal antibody directed specifically agairst the mouse macrophage. Eur J Immunol 11: 805-815, 1981.

24. Green LC, Wagner DA, Glogowski J, Skipper PL, Wishnok JS, Tannenbaum ST. Analysis of nitrate, nitrite, and ( $\left.{ }^{15} \mathrm{~N}\right)$ mitrate in biological fluids, Anal Biochem 126:131-138, 1982.

25. Dentener MA, Greve JW, Maessen JG, Buurman WA. Role of tumor necrosis factor in the enhanced sensitivity of mice to endotoxin after exposure to lead. Immunopharm Immumother 11: $321-324,1989$.

26. Wang $\mathrm{H}$, Zhang $\mathrm{M}$, Soda $\mathrm{K}$, Sama $A$, Tracey $\mathrm{KJ}$. Fetuin protects the fens from TNF. Lancet 350 : $861-862,1997$.

27. Cook HT, Bune AJ, Jansen AS, Taylor GM, Loi RK, Cattel V. Cellular localization of inducible nitric oxide synthase in experimental endotoxic shock in the rat. Clim Sci 87: 179-186, 1994.

28. Moncada S, Palmer RMJ, Higgs EA. Nitric oxide: physiology, pathophysiology and pharmacology. Pharmacol Rev 43: 109-142, 1991.

29. Ferrante $A$. Inhibition of human neutrophil locomotion by the polyamine oxidase-polyamine system. Immmology 54: 785-790, 1985.

30. Standiford TJ, Strieter RM, Lukacs NW, Kunkel SL. Neutralization of IL-10 increases lethality in endotoxemia. Cooperative effects of macrophage inflammatory protein-2 and tumor necrosis factor. J Immunol 155: 2222-2229, 1995.

31. Perretti M, Szabó $C$. Thiemermann C. Effect of interleukin-4 and interleukinm 10 on leucocyte migration and nitric oxide production in the mouse. Br If Pharmacol 116:2251-2257, 1995.

32. Tabor CW, Tabor H. Polyamines. Ann Rew Biochem 53: 749-790, 1984.

33. Unmo N, Menconi MJ, Smith M, Fink MP. Nitric oxide mediates interferon- $y$-induced hyperpermeability in cultured human intestinal epithelial monolayers. Crit Care Med 23:1170$1176,1995$.

34. Kaodass M, Sulon J, Deloyer P, Dandrifosse G. Spermine-induced precocious intestinal maturation in suckling rats: possible involvement of glucocorticoids. I Endocrinol 141; 279-283, 1994. 
$-174-$ 
CHAPTER 10

GENERAL DISCUSSION 


\section{GENERAL DISCUSSION}

\section{Polyamines and development of the mucosal immune system}

As described in Chapter 1, polyamines play a central role in the biochemical and morphological maturation of the small intestine after birth. Polyamine synthesis increases around weaning and inhibition of polyamine synthesis prevents intestinal maturation $(1,2)$. Moreover, oral polyamine administration has been shown to induce precocious intestinal maturation in neonatal rats (3-9). In Chapter 2, the natural phenotypic development of the two lymphocyte populations present in the small intestine of the mouse is described. The furst population, the intraepithelial lymphocytes (IEL), is located between the epithelial cells. These lymphocytes are separated by the basal membrane from the second lymphocyte population (lamina propria lymphocytes, LPL) present in the lamina propria $(10,11)$. In this study, it is shown that not only the phenotype of IEL and LPL are distinctive, but also the kinetics of changes in phenotype during development are different. Low numbers of the thymus dependent LPL are present at birth and these lymphocytes are almost completely differentiated at weaning. LPL mainly express TCR $\alpha \beta$, CD3, CD4, $C D 8 \propto \beta$, and CD5. In contrast almost no IEL are present at birth. Further, IEL consists of both thymus dependent $\left(\mathrm{CD}^{+}, \mathrm{TCR} \alpha \beta^{+}, \mathrm{CD} 4^{+}, \mathrm{CD} 5^{+}, \mathrm{CD} 8 \alpha \beta^{+}\right)$and thymus undependent $\left(\mathrm{CD}_{3}^{+}, \mathrm{TCR} \gamma \delta^{+}, \mathrm{CD} 8 \alpha \alpha^{+}\right)$lymphocytes and complete differentiation of these lymphocytes occurs after weaning. Interestingly, the number of thymus independent TCR $\gamma \delta^{*}$ IEL increase before weaning, whereas the increase in thymus dependent TCR $\alpha \beta^{-}$IEL takes place after weaning. These results provided a basis for the study reported in Chapter 3, in which we investigated whether oral spermine administration affects, in addition to biochemical and morphological maturation, the postnatal development of the intestinal immune system. To avoid disturbing influences of environmental and feeding conditions on the composition of IEL subsets, the control mice and spermine treated mice were recruited from the same litter. The data demonstrated that oral spermine administration induces an increase in

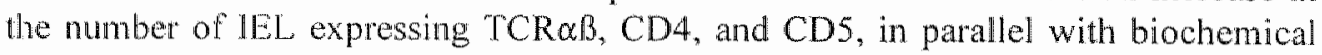
maturation of the small intestine. Although, recently controversy has risen about the usefulness of CDS expression as marker for thymus dependent lymphocytes $(12,13)$, these results indicate that oral spermine administration stimulates the phenotypic development of thymus dependent IEL (11).

The physiological increase in $\mathrm{CD}^{+}$, TCR $\alpha \beta^{*}$ IEL has been shown to be particularly triggered by bacterial colonization (14) and by the dietary changes at weaning (15-17). Since these latter conditions are associated with an increase in exogenous polyamines, it is hypothesized that polyamines are responsible for the observed phenotypic changes. Therefore, oral administration of spermine might have similar effects. In line with this hypothesis it was observed that the postnatal increase in TCR $\gamma \delta^{+}$IEL is neither affected by bacterial colonization $(14,18)$ nor by spermine 
administration (Chapter 3). Although the exact mechanism by which oral spermine administration or bacterial colonization influences the development of IEL is still unclear, an effect of spermine administration on IEL development was only observed in the mice receiving spermine from day 12 to 15 after birth. The sucrase activity observed in these mice was similar to the levels detected in mature animals, indicating that oral spermine administration induces precocious biochemical maturation of the enterocytes. In contrast, both sucrase activity and IEL phenotype were unaffected in the younger mice receiving spermine from day 7 to 10 after birth. Therefore, it is speculated that the effects of spermine on thymus dependent IEL are mediated by maturation of the epithelial cells. In support of our hypothesis, Kawaguhi-Miyashita et al. (14) recently suggested that the development of $\mathrm{CD} 4^{*}$, and TCR $\alpha \beta^{+} \mathrm{IEL}$ as a consequence of bacterial colonization is mediated by modulation of the enterocytes.

This study indicates that intraluminal polyamines do play a role in the physiological development of the small intestine and the intestinal immune system. In addition, precocious introduction of elevated luminal polyamine concentrations by oral polyamine administration to unweaned animals affects the normal intestinal development, i.e. induces sucrase activity and decreases lactase activity, and upregulates TCR $\alpha \beta, C D 4$ and CD5 expression on IEL. Although it has recently been suggested that $\mathrm{CD} 8^{+} \mathrm{TCR} \gamma \delta^{+}$cells might play a role in the development of tolerance $(19,20)$ most studies clearly indicate that $\mathrm{CD}^{*}$ intestinal lymphocytes are required for induction and maintenance of oral tolerance to food antigens (21-24). The fact that deletion of $\mathrm{CD}^{+}$intestinal lymphocytes, and not $\mathrm{CD} 8^{*}$ lymphocytes, prevents the induction of oral tolerance and that oral administration of spermine upregulates these cells, suggests that spermine administration also affects the development of oral tolerance.

\section{Intestinal NO production in coeliac disease}

As mentioned previously polyamines and nitric oxide (NO) are derived from the same precursor L-arginine. Under normal physiological conditions NO synthase (NOS) and arginase activity, leading to the formation of NO and ornithine, the precursor of polyamine synthesis, respectively, are low and in balance. In contrast, during inflammation there is an increase in iNOS activity resulting in an increased use of Larginine for NO production. NO is recognized as an important biological mediator. Its multitude of physiological and pathophysiological functions is a result from both the wide distribution of synthesis and the diverse actions of this molecule. Beneficial as well as detrimental effects of enhanced NO synthesis have been reported, suggesting that $\mathrm{NO}$ has a dualistic function in inflammation (for reviews see ref 25-27). Whereas NO offers a perfect defence mechanism against pathogenic invasion (28, 29), increased NO-production is also implicated in LPS-induced tissue damage, probably through formation of the aggressive oxidant peroxynitrite $(30-32)$ resulting in nitrotyrosine formation, the stable endproduct of the reaction of peroxynitrite with 
tyrosine. As described in Chapter 4, anti-nitrotyrosine monoclonal antibodies were developed to study $\mathrm{NO}$-mediated tissue damage by immunohistochemistry. To investigate whether NO plays a role in the pathophysiology of intestinal inflammation as a consequence of reactions to dietary components, iNOS and nitrotyrosine expression in intestinal tissue of infants with active coeliac disease were determined (Chapter 5). The small intestine of children with active coeliac disease showed clearly enhanced expression of both INOS and nitrotyrosine particularly in the crypt epithelium, suggesting a role for NO in the intestinal damage as observed in active coeliac disease. In line with this Moss et al. (33) demonstrated an increase in the number of apoptotic cells in the intestinal epithelium in patients with coeliac disease. Together these observations further support the suggested relation between iNOS, nitrotyrosine expression and apoptosis, i.e. tissue damage (34).

As shown in Chapter 5 , enhanced tissue NO production can be determined by immunohistochemical staining for iNOS and nitrotyrosine. Moreover, enhanced NO production can also be demonstrated systemically by determination of the $\mathrm{NO}$ oxidation products $\left(\mathrm{NO}_{X}\right)$, nitrate and nitrite, in biological fluids (35). In addition to earlier reported increased urinary $\mathrm{NO}_{x}$ levels in children with active coeliac disease (36), we show, in Chapter 4, the presence of enhanced plasma levels of $\mathrm{NO}_{x}$ and nitrotyrosine in these children. In comparison with plasma proteins serum, $\mathrm{NO}_{\mathrm{X}}$ has a very short half life in the circulation and will only be indicative of ongoing increased NO production. Further, NO-induced toxicity is mediated by peroxynitrite and not by nitrate and nitrite. We, therefore, developed an ELISA for determination of protein associated nitrotyrosine as a potential stable marker of NO-mediated cytotoxicity. Using this newly developed ELISA, increased plasma concentrations of nitrated proteins in coeliac disease were observed, indicating that the inflammation in active coeliac disease is not restricted to the small intestine. Both serum $\mathrm{NO}_{x}$ and nitrotyrosine decrease in patients on a gluten free diet, supporting a relation between serum $\mathrm{NO}_{\mathrm{x}}$ and nitrotyrosine levels and intestinal inflammation. The observation that chronic inflammation i.e. enhanced NO synthesis can result in an increase in plasma nitrotyrosine is supported by others (37-39).

\section{NO production in sepsis}

The involvement of $\mathrm{NO}$ in the pathophysiology of sepsis is beyond doubt (40). Because NO exerts beneficial as well as detrimental effects depending on the amount produced, the challenge is to determine the extent to which NO mediates the detrimental effects seen in sepsis. For example, increased NO synthesis causing vasodilatation is probably part of an adaptive response aimed at maximizing tissue perfusion. Clearly, overexpression of iNOS associated with overproduction of NO during sepsis can result in excessive vasodillatation resulting in vascular collapse and shock (41). Consequently, inhibition of NO synthesis during sepsis has been shown to have protective effects, particularly on the hypotension observed in this condition ( 40 - 
42). On the other hand, when non-specific NO inhibitors are administered to LPStreated animals increased intestinal and liver damage has been observed, indicating that $\mathrm{NO}$ also exerts beneficial actions $(43,44)$. This is further supported by results of Tiao et al. (45), who reported an increase in mortality after inhibition LPS-induced NO production in rats. Similarly, studies using iNOS knock out mice yielded conflicting results on the role of NO in LPS-induced mortality. Whereas Laubach et al. (46) demonstrated that iNOS knock out mice were not protected against LPSinduced lethality, others reported a partial protection from LPS-induced mortality ( 47 , 48).

A second consequence of iNOS expression and enhanced NO production during inflammation is immunoregulation. Enhanced NO production has been shown to exert both pro-inflammatory and anti-inflammatory effects. Whereas NO contributes to host defence by killing intracellular and extracellular pathogens $(28,29)$, it also exerts immunosuppressive actions such as inhibition of lymphocyte activation $(49,50)$ and of neutrophil adherence (51). Together these observations suggest that the ballance between NO production and inhibition is the critical factor determining the difference between a beneficial or an adverse effect.

To gain more insight in the regulation of LPS-induced NO release and the contribution of various organs to enhanced NO production, we investigated the role of endogenous TNF- $\alpha$, IFN- $\gamma$ and IL-10 in enhanced NO production by determination of serum $\mathrm{NO}_{\mathrm{X}}$ levels and $\mathrm{iNOS}$ expression in all major organs in a murine endotoxin model (Chapter 6 and 7). In these studies it is demonstrated that both TNF- $\alpha$ and IFN $-\gamma$ are involved in the induction of NO release after LPS challenge. Further, while on the one hand our results indicate that IL-10 down-regulates NO, TNF- $\alpha$ and IFN- $\gamma$ production, on the other hand, our results suggest the presence of an IL-10 inducible factor which together with TNF- $\alpha$ and IFN- $\gamma$ upregulates LPS-induced NO release. This dualistic effect of IL-10 on LPS-induced NO release is also evident from the literature. Whereas IL-10 has been demonstrated to reduce LPS-induced mortality and NO production (52-56), others have reported that murine IL-10 does not affect LPSinduced $\mathrm{NO}$ release, and in some experimental settings IL-10 has even been shown to enhance NO release (56-60).

Although the results from our studies point to the involvement of TNF $\cdots \alpha$, IFN- $\gamma$ and IL-10 in the regulation of NO production other mediators may also be involved. Next to TNF- $\alpha$, IFN- $\gamma$ and IL-10 several other mediators such as IL-12 $(61,62)$, IL-18 (62), IL-I $(63), \mathrm{IL}-4(57,60,64,65), \mathrm{IL}-13(60,66)$ and transforming growth factor- $\beta(67)$ have been shown to affect NO production either directly or indirectly through induction or inhibition of TNF- $\alpha$ or IFN- $\gamma$. The multitude of regulatory cytokines underscore the complexity of regulation of NO synthesis. These cytokines may regulate NO synthesis at the transcriptional, translational or functional level $(60$, $64,66,68-71$ ). With regard to the mechanisms by which cytokines can affect $\mathrm{NO}$ synthesis, it is of interest to note that inhibition of NO synthesis by IL-4 and IL-10 is associated with stimulation of arginase activity (72). As mentioned before L-arginine 
can either be converted by NOS into NO and citrulline or by arginase into ornithine, the precursor of polyamine biosynthesis. Dependent on the activity of NOS and arginase, L-arginine can be metabolized into NO or ornithine, respectively. Whereas IFN- $\gamma$ stimulates NOS activity and does not affect arginase activity, IL-4 and IL-10 appear to stimulate arginase activity without affecting NOS activity. These results suggest that IL-4 and IL-10 reduce NO synthesis by limiting the arginine pool through activation of arginase. Furthermore, in the absence of IFN- $\gamma$, both TNF- $\alpha$ and LPS have also been shown to stimulate arginase activity as well as NOS activity $(72,73)$, indicating that the use of $\mathrm{L}$-arginine for both ornithine and NO synthesis is regulated by the combination of cytokines present at the time of stimulation.

The gastrointestinal tract is thought to play a central role in the pathogenesis of sepsis since mucosal barrier dysfunction, often associated with this condition, is thought to play a role in the development of multiple organ failure (74-76). Endotoxemia and systemic bacterial infections are often associated with intestinal damage. Elevated intestinal NO production has been suggested to play a role in LPSinduced intestinal damage (77). To investigate whether a local inflammatory response is involved in the development of intestinal damage as observed during sepsis, immunohistochemical staining for INOS, macrophages and neutrophils was performed in the intestine of LPS-challenged mice (Chapter 7). Elevated expression of iNOS and an increase in the number of macrophages as well as neutrophils in the intestine after LPS challenge point to an inflammatory response in this organ. Moreover, in Chapter 9 we demonstrated that intestinal iNOS expression coincides with nitrotyrosine expression during experimental endotoxemia, supporting a role for $\mathrm{NO}$ in intestinal damage as observed in this condition.

Enhanced iNOS expression was also observed in the lung and heart but not in the liver, spleen, kidney and muscle confirming a differential induction of NO production in various organs after LPS challenge $(71,78)$. A differential induction of iNOS expression in the various organs could be expected since a wide variety of cells have been shown to express iNOS after LPS challenge. For example macrophages (78), neutrophils, endothelial cel], enterocytes, Kupffer cells (79) are known to upregulate NO production when stimulated by LPS or cytokines. All these different cell types have a distinctive sensitivity for LPS and therefore will show various levels of iNOS expression and consequently produce various amounts of NO, indicating that the cellular composition of an organ determines its NO production capacity after LPS challenge. Thus, serum $\mathrm{NO}_{x}$ levels represent $\mathrm{NO}$ produced by a composition of multiple responding cell types that have different LPS sensitivities and different time courses of NO synthesis. The resemblance of the results from Chapter 6 and Chapter 7 , describing the effect of pretreatment with anti-TNF- $\alpha$, anti-IFN- $\gamma$, anti-IL-10 antibodies or combinations thereof on serum $\mathrm{NO}_{x}$ levels and iNOS expression respectively, indicated a parallel effect of these anti-cytokine treatments on iNOS expression in the small intestine, lung and heart and on serum $\mathrm{NO}_{X}$ levels. These observations suggest that iNOS expression in these organs correlates well with the 
amount of $\mathrm{NO}$ produced determined as serum $\mathrm{NO}_{\mathrm{X}}$ levels and indicate that the small intestine, lung and heart are the major sources of enhanced NO production after LPS challenge in mice.

\section{Immunoregulatory actions of polyamines}

Polyamines are present in all living tissues $(80,81)$. Although they are generally localized in the intracellular environment polyamines can be released extracellularly as a result of cell lysis. Polyamines may be involved in inflammatory disorders since their concentrations have been shown to accumulate in inflammatory exudates $(82,83)$. Spermine and spermidine have been shown to suppress lymphocyte proliferation $m$ vitro and are suggested to modulate the release of inflammatory mediators (84). To investigate the putative anti-inflammatory effects of polyamines during an inflammatory response in man, polyamines were added to cultures of stimulated human PBMCs and monocytes. In Chapter 8 , we demonstrated that polyamines themselves have no direct anti-inflammatory effects on human blood mononuclear cells in vitro. In contrast, oxidation of the polyamines spermine and spermidine by polyamine oxidase ( $\mathrm{PAO}$ ), present in bovine serum, results in the formation of products which exert pro-inflammatory effects, i.e. enhance cytokine release. These effects occur when polyamines concentrations used are below $3 \mu \mathrm{M}$. In accordance with the pro-inflammatory actions of polyamines Purcell et al. (85) have shown that polyamines induce histamine release by rat peritoneal macrophages. In addition, Walter et al. $(86,87)$ demonstrated that blocking polyamine production results in inhibition of the respiratory burst of human polymorphonuclear leukocytes (PMNs) and addition of polyamines enhances the secretory and oxidative function of PMNs, suggesting that polyamines play a role in the upregulation of antimicrobial activities of PMNS. It should be mentioned, however, that it is not clear from these reports whether these pro-inflammatory effects observed after addition of polyamines to PMNs cultures were mediated by polyamine oxidation products or by polyamines themselves.

In contrast, when higher concentrations of polyamines $(>3 \mu \mathrm{M})$ were used in the presence of $\mathrm{PAO}$, an inhibition of pro- and anti-inflammatory cytokines was observed coinciding with a decrease in cell viability. These results indicate that high concentrations of oxidized polyamines exert cytotoxic effects and thereby reduce cytokine release. In line with the suggested cytotoxic effects, it has been demonstrated that PAO release by stimulated macrophages in the presence of polyamines in the culture medium results in the formation of polyamine degradation products which have been shown to lyse or limit the proliferation of tumor cells, lymphocytes and micro-organisms $(80,88-92)$. Release of PAO activity is at least one of the mechanisms by which macrophages exert cytostatic and cytolytic effects (89). Together these studies suggest that, similarly to $\mathrm{NO}$, oxidized polyamines are involved in the nonspecific host defence. On the other hand, and parallel to NO, enhanced PAO 
activity and polyamine concentrations seem to be inwolved in the ongoing process of chronic inflammation. Lovaas et al. (93) suggested that the high concentrations of spermine detected in the joint of rheumatoid arthritis patients act as anti-oxidant and may be protective against inflammatory damage of the joint. In contrast, Flescher and colleagues clearly demonstrated that elevation of polyamines concentrations coincides by an increase in PAO activity in the joints of these patients yielding lymphocytoxic levels of polyamine oxidation products. These polyamine oxidation products are responsible for the suppression of lymphocyte viability and function characteristics, such as $I$ L-2 production, in these patients (94-97). Taken together, these results suggest that polyamine oxidation products are at least partly responsible for the ongoing inflammatory response as observed in these patients.

In Chapter 9 we showed that, in contrast to our in vitro study with human mononuclear cells, spermine inhibits LPS-induced NO release by a murine macrophage cell line (RAW), without affecting TNF- $\alpha$ production and cell viability. It seems likely, therefore, that given the presence of intrinsic PAO activity in stimulated murine macrophages, polyamine oxidation products do not affect macrophage viability in the mouse. In contrast, undifferentiated human peripheral blood monocytes lacking PAO activity, are sensitive to the cytotoxic effects of polyamine oxidation products resulting in inhibition of TNF- $\alpha$ production $(96,98)$. These observations suggest distinct effects of spermine on different cell types.

To further extend our investigations on the putative anti-inflammatory actions of spermine and given the fact that exogenous polyamines do inhibit NO release in vitro and are essential for the maintenance of mucosal integrity, spermine was administered orally to mice prior to treatment with LPS. In Chapter 9, it is shown that oral spermine administration inhibits intestinal iNOS expression and nitrotyrosine formation, indicating a reduction of LPS-induced intestinal damage. While we have demonstrated that exogenous polyamines have a protective effect on LPS-induced intestinal damage, others have provided further evidence for beneficial potential of exogenous polyamines by demonstrating that intraluminal polyamines enhance intestinal repair (99-100) probably by stimulating intestinal transglutaminase activity (101). Furthermore, systemic levels of $\mathrm{NO}_{x}$ and $I F N-\gamma$ were inhibited and IL-10 levels increased, indicating that exogenous spermine also suppresses the release of proinflammatory mediators. In support with our observations intraluminally derived polyamines have been shown to modulate NK cytotoxic activity, the number of leukocytes, IL-2 production and T cell phenotype in tumor bearing mice $(102,103)$. Although the mechanism involved in modulation of the immune system by intraluminal derived polyamines is unclear, it is evident that they have to be administered orally. In contrast to orally given polyamines, intraperitoneally and intravenously given polyamines are extremely toxic (104-106). As mentioned in the introduction normal physiological concentrations of polyamines in the intestine are relatively high as compared to other organs and can originate from the either the diet, 
gut bacteria or extruded enterocytes (107). Therefore oral polyamine administration is a more physiological route than intraperitoneal or intravenous administration.

Taken together the studies described in this thesis demonstrate that exogenous polyamines affect both the development of the intestinal immune system after birth (Chapter 3) and play an immunoregulatory role in (patho-) physiological immune responses (Chapter 9). Similarly to NO, polyamines exert both beneficial and detrimental effects depending on their concentration and localization. Further, both polyamines and NO are important mediators in inflammation, as illustrated by the observation that they enhance the nonspecific defence mechanism of macrophages, and exert beneficial, i.e. anti-inflammatory, as well as detrimental, i.e. proinflammatory, effects. However, polyamines and $\mathrm{NO}$ also exhibit opposite effects. For example, whereas NO is involved in the induction of LPS-induced intestinal damage, intraluminal polyamines seem to be involved in inhibition of intestinal damage. The findings in this thesis firmly support a central role for $\mathrm{NO}$ in the physiological immune response, inflammation and sepsis. The multitude of regulatory cytokines and wide variety of actions of $\mathrm{NO}$ underscore the complexity of regulation of NO synthesis and the intricacy of the distinctive effects of NO production. Moreover, in this thesis we have provided evidence for an equally important role for polyamines in these situations. The observed effects of polyamine administration on the development of the intestinal immune system, on intestinal damage and on systemic inflammation might present therapeutic perspectives for treatment of food allergy, sepsis and other disorder characterized by intestinal inflammation.

\section{REFERENCES}

1. Luk GD, Marton LJ, Baylin SB. Ornithine decarboxylase is important in intestinal mucosal maturation and recovery from injury in rats, Science 210: 195-198, 1980.

2. Alarcon P, Lebenthal E, Lee PC. Effect of diffuoromethyl onithine (DFMO) on small intestine of adult and weanling rats. Dig Dis Sci 32: 883-888, 1987.

3. Harada $E$, Hashimoto $Y$, Syoto B. Orally administered spermine induces precocious intestinal maturation of macromolecular transport and disaccharidase development in suckling rats. Comp Biochem Physiol 109A: 667-673, 1994.

4. Kaouass $M$, Deloyer $P$, Dandrifosse $G$. Intestinal development in suckling rats: direct or indirect spermine action? Digestion 55: 160-167, 1994.

5. Kaovass M, Sulon J, Deloyer P, Dandrifosse G. Spermine-induced intesinal maturation in suckling rats: possible involvement of glucocorticoids. J Endocrinol 141: 279-283, 1994.

6. Dufour $C$, Dandrifosse $G$, Forget $P$, Vermesse F, Romain $N$, Lepoint P. Spermine and spermidine induce intestinal maturation in rat. Gastroenterology 95: 112-116, 1988.

7. Georges P, Dandrifosse G, Vermesse F, Forget P, Deloyer P, Romain N. Reversibility of spermine-induced intestinal maturation in the rat. Dig Dis Sci 35: 1528-1536, 1990.

8. Buts JP, De Keyser N, Kolanowski J, Sokal E, Van Hoof F. Maturation of villus and crypt cell functions in rat small intestine. The role of dietary polyamines. Dig Dis Sci 38: $1091-1098,1993$. 
9. Wild GE, Daly AS, Sauriol N, Bennett G. Effect of exogenously administered polyamine on the structural maturation and enzyme ontogeny of the postnatal rat intestine. Biol Neonate $63: 246$ 257. 1993.

10. Poussier $P$, Julius $M$. Thymus independent $T$ cell development and selection in the intestinal epithelium. Annu Rev Immunal 12:521-553, 1994.

11. Lefrancois $\mathrm{L}$, Olson $\mathrm{S}$. Reconstruction of the extrathymic intestinal $T$ cell compartment in the absence of irradiation. J Inwmonol 159:538-541, 1997.

12. Muller $\mathrm{S}$, Jungo $\mathrm{M}$, Aichele $\mathrm{P}$, Mueller $\mathrm{C}$. CD5(-)CD8-alpha-beta intestinal intraepithelial lymphocytes (IEL) are induced to express CDS upon antigen-specific activation-CD5(-) and CDS $(+)$ CD8-alpha-beta IEL do not represent separate T cell lineages. Eur $J$ Immunal $27: 1756-$ $1761,1997$.

13. Ferguson A, Parrot DMV. The effect of antigen deprivation on thymus-dependent and thymusindependent lymphocytes in the small intestine of the mouse. Clin Exp Immunol 12: 477-488, 1972.

14. Kawaguchi-Miyashita M, Namo M, Shmada S, Nagaoka N, Okada Y, Matsumoto S, Umesaki $Y$, Matsuoka $Y$, Ohwaki M. A step-wise expansion of intestinal intraepithellial $T$ lymphocytes in association with microbial colonization is defined by sensitivity to cyclosporin A. Immunol 91 : $628-634,1997$.

15. Ter Steege ICA, Burman WA, Forget PPh. The neonatal development of intraepithelial and lamina propria lymphocytes in the murine small intestine. Dev Immunol 5: 121-128, 1997.

16. Machado CSM, Roderiques MAM, Maffei HVL. Assessment of gut intraepithelial lymphocytes during late gestation and the neonatal period. Biol Neonate 66: 324-329, 1994.

17. Rothköter HJ, Kirchhoff T, Pabst R. Lymphoid and nonlymphoid cells in the epithelium and lamina propria of intestinal mucosa of pigs. Gut 35: 1582-1589, 1994.

18. Bandeira $\mathrm{A}$, Mota-Santos T, Itohara $\mathrm{S}$, Degermann $\mathrm{S}$, Huesser $\mathrm{C}$, Tonegawa $\mathrm{S}$, Coutino $\mathrm{A}$. Localization of $\gamma / 0 \mathrm{~T}$ cells to the intestinal epithelium is independent of normal microbial colonization. J Exp Med 172: 239-244, 1990.

19. Wildner $G$, Hüning $T$, Thurau SR. Orally induced, peptide-specific $\gamma / \delta$ TCR* cells suppress experimental autoimmune uveitis. Eur J Immunol 26:2140m2148, 1996.

20. Ke Y, Pearce K, Lake JP, Ziegler IK, Kapp JA. $\gamma \delta$ T Jymphocytes regulate the induction and maintenance of oral tolerance. I Immumol 158:3610-3618, 1997.

21. Khoo UY, Proctor IE, Macpherson AJS. CD4 $\mathbb{I}$ cell down-regulation in human intestinal mucosa. Evidence for intestinal tolerance to luminal bacterial antigens. I Immunol 158: 3626 3634, 1997.

22. Barone KS, Jain SL, Michael JG. Effect of in wivo depletion of CD4 and CD8* cells on the induction and maintenance of oral tolerance. Cel/ twmunology 163: 19-29, 1995 .

23. Garside P. Steel M, Liew FY, Mowat AM. CD4* but not CD8 $\mathrm{T}$ cells are required for induction of oral tolerance. Int Immunol 7: 501-504, 1995.

24. Vistica BP, Chanaud NP, Felix N, Caspi RR, Rizzo LV, Nussenblatt RB, Gery I. CD8 T-cells are not essential tor the induction of "low dose" oral tolerance. Clin lmmunol Immunopathol 78 : 196-202, 1996.

25. Nussler AK, Billiar TR. Inflammation, immunoregulation, and inducible nitric oxide synthase. $J$ Leukoc Biol 54: 171-178, 1993 .

26. Moilanen E, Vapatatalo H. Nitric oxide in inflammation and immune response. Am Med 27: 359 . $367,1995$.

27. Billiar TR. Nitric oxide. Novel biology with clinical relevance. Ann Surg 221:339-349, 1995.

28. Reddy D, Lancaster JR, Conforth DP. Nitrice inluibition of Clostridium botulmum: electron spin resonance detection of iron-nitric oxide complexes. Science 221: 769-770, 1983. 
29. Woods LFJ, Wood JM, Gibbs PA. The involvement of nitric oxide in the inhibition of the phosphoroclastic system in Clostridium sporogenes by sodium nitrite. J Gen Microbiol 125: 399-406, 1981 .

30. Ischiropolous $\mathrm{H}$, Al-Mehdi AB. Peroxynitrite-mediated oxidative protein modifications. FEBS Lett $364: 279-282,1995$.

31. Beckman JS. Oxidative damage and tyrosine formation from peroxynitrite. Chem Res Toxicol 9 : $836-844,1996$.

32. Ischiropoulos $\mathrm{H}$, Zhu L, Beckmann JS. Peroxynitrite formation from macrophage-derived nitric oxide. Arch Biochem Biophys 298: 446-451, 1992.

33. Moss SF, Attia L, Scholes JV, Walters JRF, Holt PR. Increased small intestinal apoptosis in coeliac disease. Gut 39: 811-817, 1996.

34. Gal A, Tamir S, Kennedy LJ, Tannenbaurn SR, Wogan GN. Nitrotyrosine formation, apoptosis, and oxidative damage: Relationships to nitric oxide production in SJL mice bearing the ResX tumor. Cancer Res 57: 1823-1828, 1997.

35. Green LC, Wagner DA, Glogowski J, Skipper PL, Wishnok JS, Tamnenbanum ST. Analysis of nitrate, nitrite and $\left({ }^{15} \mathrm{~N}\right)$ nitrate in biological fluids. Anal Biochem 126:131-138, 1982.

36. Van Straaten EA, Koster-Kamphuis L, Bovee-Oudenhoven IM, Van der Meer R, Forget PPh. Increased urinary nitric oxide oxidation products in children with active coeliac disense. Submitted to Acta Paediar Scand.

37. Kuar $\mathrm{H}$, Halliwell $\mathrm{B}$. Evidence for nitric oxide-mediated oxiclative damage in chronic inflammation. Nitrotyrosine in serum and synovial fluid from rheumatoid patients. FEBS LeVt 350: 9-12, 1994.

38. Fukuyama $N$, Takebayashi $Y$, Hida $M$, Ishida $H$, Ichimori $K$, Nakazawa $H$. Clinical evidence of peroxynitrite formation in chronic renal failure patients with septic shock. Free Radical Biol Med 22: 771-774, 1997.

39. Skinner KA, Crow JP, Skinner HB, Chandler RT, Thompson JA, Parks DA. Free and proteinassaciated nitrotyrosine formation following rat liver preservation and transplantation. Anch Biochem Biophys 342: 282-288, 1997.

40. Vallance P, Moncada S. Role of endogenous nitric oxide in septic shock. New Horizons 1: 77 $86,1993$.

41. Kilbourn RG, Jurban $A_{2}$ Gross SS et al. Reversal of endotoxin mediated shock by $N^{C}$-methylarginine, an inhibitor of nitric oxide synthesis. Biochem Biophys Res Commun 172: 1132-1138. 1991 .

42. Petros $A$, Bennett $D$, Vallance $P$. Effect if nitric oxide synthase inhibitors on hypotension impatients with septic shock. Lancet 338: 1557-1558, 1991 .

43. Seekamp A. Mulligan MS, Till GO, Ward PA. Requirements of neutrophil products and Larginine in ischenia-reperfusion injury. Am I Pathol 142: $1217-1226,1993$.

44. Hutcheson AR, Whittle BJR, Bougthon-Smith NK. Role of nitric oxide in maintaining vascular integrity in endotoxin-induced acute intestinal damage in rat. $B^{*}$. Phamacol $101: 815-820$, 1990.

45. Tiao G, Rafferty J, Ogle C, Fischer JE. Detrimental effect of nitric oxide synthase inhibition during endotoxemia may be caused by high levels of tumor necrosis factor and interleukin-6. Surgery 116: 332-338, 1994.

46. Laubach VE, Shesely EG, Smithies O, Sheman PA. Mice lacking inducible nitric oxide synthase are not resistant to lipopolysaccharide-induced death. Proc Nat Acad Sci USA 92: $10688-10692,1995$.

47. Weil X, Charles IG, Smith A, Ure J, Feng G, Huang F, Xu D, Muller W, Moncada S, Liew FY, Altered immune responses in mice lacking nitric oxide synthase. Noture 375: 408-411, 1995. 
48. MacMicking JD, Nathan C, Hom G, Chartain N, Fletcher DS, Trumbauer M, Stevens K. Xie Q, Sokol $K$. Hutchinson $N$, Chen $H$, Mudgett IS. Altered responses to bacterial infection and endotoxin shock in mice lacking inducible nitric oxide synthase. Cell 81: 641-650, 1995.

49. Mils CD. Molecular basis of "suppressor" macrophages. Arginine metabolism via the nitric oxide synthetase pathway. I Immunol 146:2719-2723, 1991.

50. Albina JE, Abate JA. Henry WL. Nitric oxide production is required for murine resident peritoneal macrophages to suppress mitogen-stimulated $T$ cell proliferation. Role IFN- $\gamma$ in the induction of the nitric oxide synthesizing pathway. I Immunol 147: 144-148, 1991 .

51. Kubes $P$, Suzuki M, Granger DN. Nitric oxide: an endogenous modulators of leukocyte adhesion. Proc Nat Acad Sct USA 88: 4651-4655, 1991.

52. Gérard $C$, Bruyns $C$, Marchant A, Abramowicz D, Vandenabeele P, Delvaux A, Fiers W, Goldman M. Velu $\mathbb{T}$. Interleukin 10 reduces the release of tumor necrosis factor and prevents lethality in experimental endotoxemia. $J$ Exp Med 177: 547-550, 1993.

53. Moore KW, OGarra A, Malefyt RW, Vieira P, Mosmann TR. Interleukin-10. Amm Rev Immunol $11: 165-190,1993$.

54. Cenci $\mathbb{E}$, Romani L, Mencacci A, Spacca-Sichiaffella E, Puccetti P, Bistonï F. Interleukin-4 and interleukin-10 inhibit nitric oxide-dependent macrophage killing of Candida albicans. Eur $J$ lminnunol 23: 1034-1038, 1993.

55. Cunha FQ, Moncada S, Liew FY. Interleukin-10 (LL-10) inhibits the induction of nitric oxide synthase by interferon- $\gamma$ in murine macrophages. Biochem Biophys Res Commun 182: 11551159,1992 .

56. Appelberg R. Opposing effects of interleukin-10 on mouse macrophage function. Scand $y$ Immennol 4 1: $539-544,1995$.

57. Maru A, Jackson SK. Opposite effects of interleukin-4 and interleukin-10 on nitric oxide production in murine macrophages. Med Inflamm 5: 110-112, 1996.

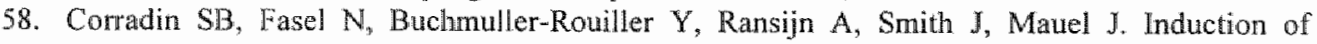
macrophage nitric oxide production by interferon- $\gamma$ and tumor necrosis factor- $\alpha$ is enhanced by IL-10. Eur J Immumol 23: 2045-2048, 1993.

59. Chesrown SE, Morrier J, Visner G, Nick HS. Regulation of nitric oxide synthase mRNA levels by LPS, IFN- $\gamma$, TNF $B$ and $\mathbb{L}-10$ in murine macrophage cell lines and rat peritoneal macrophages. Brochem Biophys Res Commwn 200: 126-134, 1994.

60. Berkman N, Robichaud A, Robbins RA, Roesens G, Haddad EB, Barnes PI, Chung KF. Inhibition of inducible nitric oxide synthase expression by interletkin-4 and interleukin- 13 in human lung epithellial cells. Immmol 89: 363-367, 1996.

61. Zidck Z, Lotzová E, Franková D, Savary CA. Indirect stimulatory effects of murine interleukin12 on in vilro production of nitric oxide by mouse peritoneal cells. Intexferon Cyokine Res 16: $339 \times 349.1996$.

62. Zhang $T$, Kawakami K, Qureshi MH, Okamura H, Kurmoto M, Saito A. Interleukin-12 (IL-12) and $1 L-18$ synergistically induce the fungicidal activity of murine peritoneal exudate cells ageinst Cryptococcus neoformans through production of ganma interferon by natural killer cells. Iiffect Immun 65: 3594-3599, 1997.

63. Cunha FQ, Assreuy j, Moss DW, Rees D, Leal LMC, Moncada S, Carrier M. Differential induction of nitric oxide synthase in various organs of the mouse during endotoxemia; role of TNF- and IL-1-B. Immmol 81: 211-215, 1994.

64. Sands WA. Bulut V, Severn A, Xu D, Liew FY. Inhibition of nitric oxide synthesis by interleukin-4 may involve inhibiting the activation of protein kinase C epsilon. Eur J Immunol 24: 2345-2350, 1994.

65. Liew FY, Li Y, Severn A, Millott S, Schmidt J, Salter M. Moncada S. A possible novel pathway of regulation by murine $T$ helper type-2 (Th2) cells of a Th1 cell activity via the modulation of the induction of nitric oxide synthase on macrophages. Eur I tmmumol 21: 2489-2494, 1991. 
66. Bogdan $C$, Thuring H, Dlaska M, Rollinghoff M, Weiss G. Mechanisms of suppression of macrophage nitric oxide release by $\mathbb{1 L}-13$ : infuence of the macrophage population. If Immumol 159: 4506-4513, 1997.

67. Vincent VAM, Tilders FIH, Vandam AM. Inhibition of endotoxin-induced nitric oxide synthase production in microglial cells by the presence of astroghal cells - a role for transforning growth factor beta. Glia 19: 190-198, 1997.

68. Nathan $\mathrm{C}$, and Xie QJ. Regulation of biosynthesis of nitric oxide. J Biol Chem 269: 13725$13728,1994$.

69. Gazzinelli RT, Oswald IP, James SL, Sher A. IL-10 inhibits parasite killing and mitrogen oxide production by IFN- $\gamma$-activated macrophages. I Imm who? 148: 1792 1796, 1992.

70. Flesch IEA, Hess JH, Oswald IP, Kaufmann SHE. Growth inhibition of Mycobacterium bovis by IFN- $\gamma$ stimulated macrophages: regulation by endogenous tumor necrosis facto- $\alpha$ and by IL-10. Int Immunol 6: 693-700, 1994.

71. Bogdan C, Vodovotz X, Paik J, Xie Q, Nathan C. Mechanism of suppression of nitric oxide synthase expression by interleukin-4 in primary mouse macrophages J Leukoc Biol $55 ; 277-233$, 1994.

72. Modolell M, Corraliza IM, Link F, Soler G, Eichmann $K$. Reciprocal regulation of the nitric oxide synthase/arginase balance in mouse bone marrow-derived macrophages by $\mathrm{TH} 1$ and $\mathrm{TH} 2$ cytokines. Eur J Immunol 25:1101-1104, 1995.

73. Benninghoff $B$, Lehman V, Eck FP, Droge W. Production of citrulline and omithine by interferon- $y$ treated macrophages. Int Immunol 3, 413-417, 1991.

74. Wilmore DW, Smith RJ, O'Dwyer ST, Jacobs DO, Ziegler TR, Wang XD. The gur: a central organ after surgical stress. Surgery 104: 917-923, 1988.

75. Marshall JC, Christow NV, Horn R, Meakins JL. The microbiology of multiple organ failure. The proximal gastrointestinal tract as an occult reservoir of paihogens. Arch Sturg 123: 309-314, 1988.

76. Antonsson JB, Fiddian-Green RG. The role of the gut in shock and multiple system organ failure. Eur J Surg 157: 3-12, 1991.

77. Chamulitrat W, Skrepnik NV, Spitzer J. Endotoxin-induced oxidative stress in the rat smail intestine: role of nitric oxide. Shock 5:217-222, 1996.

78. Salkowski CA, Detore G, McNally $R$, van Rooijen N, Vogel SN. Regulation of inducible nitric oxide synthase messenger RNA expression and nitric oxide production by lipopolysaccharide in wivo.J Immunol 158: 905-912,1997.

79. Billiar TR, Curran RD, Stuehr DJ, West MA, Bentz BG, Simmons RL. An L-arginine-dependent mechanism mediates Kupffer cell inhibition of hepatocyte protein synthesis in vitro. $J$ Exp Med $169: 1467-1472,1989$.

80. Tabor $\mathrm{H}$, Tabor $\mathrm{CW}$. Biosynthesis and metabolism of 1,4-dianinebutane, spermine, spermidine and related amines. Enzymol 36:203-268, 1972.

81. Tabor H, Tabor CW. Spermidine, spermine and related amines. Pharmacol Rev 16: 245m300, 1964.

82. In Polyamines in Biomedical Research. JM Gauges (Ed.), John Wiley \& Sons, Chichester, 1980.

83. Bird J, Mohd Hidir S, Lewis DA. Putrescine - a potent endogenous anti-inflammatory substance in inflammatory exudates. Agenis Actions 13: 342-347, 1983.

84. Theoharides TC. Polyamines spermidine and spermine as modulators of calcium-dependent immune processes. Life Sci 27: 703-713, 1980.

85. Purcell WM, Doyle KM., Westgate C, Atterwill CK. Characterization of a functional polyamine site on rat mast cells: association with a NMDA receptor macrocomplex. I Newoimmumol 65 : $49-53,1996$. 
86. Walters JD, Chapman KJ. Polyamines found in gingival fluid enhance the secretory and oxidative function of human polymorphonuclear leukocytes in vitro. J Periodont Res 29: 167171,1995 .

87. Walters JD, Cario AC, Danne MM, Marucha PT. An inhibitor of omithine decarboxylase antagonizes superoxide generation by primed human polymorphonuclear leukocytes. I Inflamm $48: 40-46,1998$.

8.8. Johnson WC, Cluff CW, Goff WL, Wyatt CR. Reactive oxygen and nitrogen internediates and products from polyamine degradation are Babesiacidal in vitro. Ann $N Y$ Acad $5 c i$ 791: 136-147. 1996.

89. Allison $\mathrm{AC}$, Ferluga $\mathrm{J}$, Prydz $\mathrm{H}$, Schorlemmer $\mathrm{HU}$. The role of macrophage activation in chronic inflammation. Agent Actions 8: 27-35, 1978.

90. Ferrante A, Rzepczyk CM, Allison AC. Polyamine oxidase mediates intra-erythrocytic death of Plasmodium falciparum. Trans R Soc Trop Med Hyg 77: 789-791, 1983.

91. Morgan DML, Christense JR, Allison AC. Polyamine oxidase and the killing of intracellular parasites. Biochem Soc Trans 9: 563-564, 1981 .

92. Ali-Osman F, Maurer HR. Stimulation of clonal tumor cell growth in vitro by inhibiting the serum polyamine oxidase activity. $J$ Cancer Res Clin Oncol 106: 17-20, 1983.

93. Lovaas E, Carlin G. Spermine: an anti-oxidant and anti-inflanmatory agent. Free Radical Biol Med 11: $445-461,1991$.

94. Flescher E, Bowlin TL, Talal N. Polyamine oxidation down-regulates IL-2 production by human peripheral blood mononuclear cells. J Immunol 142: 907-912, 1989.

95. Flescher E, Bowlin TL, Ballester A, Houk R, Talal N. Increased polyamines may downregulate interleukin 2 production in rheumatoid arthritis. J Clin Invest 83: 1356-1362, 1989.

96. Flescher E, Fossum D, Tallal N. Polyamine-dependent production of lymphotoxic levels of ammonia by human peripheral blood monocytes. Immunol Lett 28: 85-89, 1991.

97. Flescher $\mathrm{E}$, Bowlin TL, Talal N. Regulation of IL-2 production by mononuclear cells from rheumatoid arthritis synovial fluids. Clin Exp Immunol 87: 435-437, 1992.

98. Morgan DML, Fergula J, Allison AC. Polyamine oxidase and macrophage function . In Polyamines in Bionedical Research. JM Gauges (Ed.), John Wiley and Sons, New York, pp. $303,1980$.

99. Wang JY, Johnson LR. Luminal polyamines substitute for tissue polyamines in duodenal mucosal repair after stress in rats. Gastroenterology 102: 1109-1117, 1992.

100. Dowling RH. Polyamines in intestinal adaptation and disease. Digestion 46 suppl 2: $331-344$, 1990.

101. Wang JY. Viar MJ, Johnson LR. Regulation of transglutaminase activity by polyamines in the gastrointestinal mucosa of rats. PSEBM 205: 20-28, 1994.

102. Chamaillard L. Quemener V. Havouis R, Moulinoux JP. Polyanine deprivation stimulates natural killer cell activity in cancerous mice. Anticancer Res 13: 1027-1033, 1993.

103. Chamaillard L, Catros-Quemener V, Delcros JG. Bansard JY, Havouis R, Desury D, Commeurec A, Genetet N, Moulinoux JP. Polyamine deprivation prevents the development of tumor-induced immune suppression. B ${ }^{4}, J$ Cancer $76: 365-370,1997$.

104. Shaw GG. Some pharmacological properties of the polyamines spermine and spermidine - a reappraisal. Arch Int Pharacodyn 198: 36-48, 1972.

105. Rosenthal SM, Fischer ER, Stohlman EF. Nephrotoxic actions of spermine. Proc Soc Exp Biol Med 80: 432-434, 1952.

106. Tabor CW. Rosenthal SM. Pharmacology of spermine and spermidine: some effects on animals and bateria. I Phamacol Exp Ther 116:139-155, 1956.

107. Osborne DL, Seidel ER. Gastrointestinal luminal polyamines: Cellular accumulation and enterohepatic circulation. Am J Physiol 258: G576-G584, 1990. 


\section{CHAPTER 11}

SUMMARY/SAMENVATTING 


\section{SUMMARY}

The first section of Chapter 1 is focused on polyamines and their synthesis in general. Polyamines are organic amines with an aliphatic carbon chain. These cellular compounds are involved in a wide variety of cellular processes and are essential for cell proliferation, however, the actual function of these amines is still unclear. The second section deals with the important role of polyamines in the maturation of the intestinal mucosa and immune system after birth. Inhibition of polyamine synthesis in neonatal rodents prevents morphological and biochemical maturation of the small intestine, indicating that polyamine biosynthesis is essential for normal intestinal development after birth.

The notion that polyamines are essential for maintenance of intestinal integrity is derived from studies in which inhibition of intestinal polyamine synthesis was shown to induce villus atrophy. Moreover, enhanced intestinal polyamine concentrations have been shown to stimulate intestinal repair. Interestingly polyamines are derived from L-arginine, which is also the precursor for the potent pro-inflammatory mediator NO. Therefore the third section of Chapter 1 describes the role of NO in intestinal integrity and inflammation. In contrast to polyamines, enhanced NO production is involved in the increase in intestinal permeability as observed during inflammation. The role both polyamines and NO in intestinal inflammation as observed in coeliac disease and sepsis is discussed.

At the end of the introduction the role of polyamines in the immune system is depicted. On the one hand, polyamines are essential for proliferating cells and consequently for cell activation and proliferation in response to mitogenous stimuli. On the other hand high concentrations of polyamines as detected in tumor and foetal tissue, are thought to be involved in the absence of an immune response to these tissues. In line with this inhibition of polyamine synthesis in tumor bearing mice has been shown to enhance immune activity against the tumor activity, further supporting an immunosuppressive role for these aliphatic cations in vivo. In addition, the role of polyamine oxidase activity in relation with this immunosuppressive actions of polyamines is discussed.

In Chapter 2 the normal phenotypic development of intraepithelial lymphocytes (IEL) and lamina propria (LPL) after birth in mice is described. Whereas the number of LPL increase before day 15, the number of IEL expands after day 15. Around weaning (day 20 ) both IEL and LPL differentiate to a mature pattern of cellular membrane antigen expression. Further, the increase in the number of thymus independent IEL expressing TCR yo takes place before that of the thymus dependent TCR $\beta_{3}{ }^{+}$IEL. The increase in latter cell population is triggered by the change of food around weaning. In conclusion, the mouse mucosal immune system develops during the first 3 weeks of neonatal life leading to the formation of a more mature immune system at weaning. 
In Chapter 3 it is demonstrated that exogenous polyamines are involved in the development of the mucosal immune system, next to the biochemical development of the enterocytes. Oral spermine administration to mice at day 12 after birth induces an increase in the number of IEL expressing TCR $\alpha B, C D 4$ and $C D 5$, the phenotype of thymus dependent IEL, whereas the phenotype of the LPL is unaffected. Since the effect of spermine on IEL coincides with a biochemical maturation of the enterocytes, it is suggested that IEL development might be mediated by enterocytic maturation.

In Chapter 4 the development of an ELISA for determination of protein associated nitrotyrosine in plasma samples is described. NO reacts with superoxide to yield the strong oxidant peroxynitrite. Nitrotyrosine is the stable endproduct from the reaction of peroxynitrite and tyrosine residues. Plasma (serum) levels of NO-oxidation products $\left(\mathrm{NO}_{\mathrm{X}}\right)$ nitrate and nitrite are used as indicators for enhanced NO production. However, plasma $\mathrm{NO}_{\mathrm{X}}$ levels have, in contrast to plasma proteins, a very short half life. Further $\mathrm{NO}$-induced cytotoxicity is mediated through peroxynitrite and not $\mathrm{NO}_{\mathrm{x}}$. Therefore, protein-associated nitrotyrosine levels might be a more stable marker for NO-mediated cytotoxic effects than $\mathrm{NO}_{x}$ levels. In this chapter it is, further, demonstrated that the concentrations of nitrotyrosine and $\mathrm{NO}_{\mathrm{x}}$ are enhanced in plasma of children with active coeliac disease. Both plasma levels of nitrotyrosine and $\mathrm{NO}_{\mathrm{X}}$ decrease when the children are on a gluten free diet suggesting a relation between intestinal inflammation and enhanced plasma levels of nitrotyrosine and $\mathrm{NO}_{\mathrm{x}}$.

In Chapter 5 the role for NO in the pathophysiology of intestinal inflammation as observed in patients with active coeliac disease patients is further supported by immunohistochemical staining of intestinal biopsy tissue for iNOS and nitrotyrosine. Inducible NOS expression, clearly present in the crypt epithelium, coincides with nitrotyrosine staining, indicating formation of peroxynitrite resulting in nitration of cellular proteins. In addition, the number of intestinal macrophages is also enhanced, particularly the number of tissue infiltrating macrophages, which in contrast to intestinal macrophages express CD14. The observed colocalization of iNOS and CD14 expression suggests a role for these tissue infiltrating macrophages in the pathophysiology of coeliac disease.

In Chapter 6 the role of endogenous TNF- $\alpha$, IFN- $\gamma$ and IL-10 in LPS-induced NO release in vivo is evaluated in a experimental murine sepsis model. While blocking either TNF- $\alpha$ or IFN- $\gamma$ has no effect on LPS-induced serum NO-oxidation levels, blocking both pro-inflammatory mediators almost completely inhibits LPS-induced NO release, indicating that NO is induced by at least two pathways one through TNF- $\alpha$ and one through IFN- $\gamma$. Interestingly, while IL-10 decreases L.PS-induced NO release by inhibition of TNF- $\alpha$ and IFN- $\gamma$ production, our results with combined treatment of anti-IL-10 with anti-TNF- $\alpha$ or anti-IFN- $\gamma$ suggest the presence of an 
IL 10 induced factor which is, in addition to TNF $\alpha$ and IFN- $\gamma$, involved in the upregulation of NO release after LPS challenge.

In Chapter 7 it is demonstrated that the small intestine, lung and heart are the major organs involved in enhanced NO production in mice after LPS challenge in vivo. In addition it is shown that NOS expression in these organs is regulated by TNF- $\alpha$, IFN- $\gamma$ and IL-10. Whereas the presence of either TNF- $\alpha$ or IFN- $\gamma$ is essential for iNOS expression in these organs after LPS challenge, IL-10 is involved in the downregulation of iNOS expression through inhibition of TNF- $\alpha$ and IFN- $\gamma$ synthesis. In contrast, however, our results obtained with combined treatment of antiIL-10 with anti-TNF- $\alpha$ or anti-IFN- $\gamma$ might indicate a possible role for IL-10, or an IL-10 induced factor, in the upregulation of iNOS expression in these organs after LPS challenge.

In Chapter 8 the effects of the polyamines, cadaverine, putrescine, spermidine and spermine on cytokine release of stimulated human PBMCs and purified monocytes are studied in vitro. Polyamines themselves appear not to exert any effect on the basal as well as on PHLA- or LPS-induced cytokine release of these cells. In contrast, in the presence of polyamine oxidase activity, spermine and spermidine are oxidized into products which exert pro-inflammatory actions, i.e. enhance cytokine release, when present in low concentrations and inhibit release of pro-inflammatory as well as antiinflammatory cytokines, when present in higher concentrations. Inhibition of cytokine release coincides with a decrease in cell viability suggesting that these polyamine oxiclation products are cytotoxic for human PBMCs and monocytes.

In Chapter 9 evidence is provided indicating that exogenous polyamines inhibit LPSinduced NO production in vitro as well. as in wivo. Inhibition of LPS-induced NO release by spermine in the murine macrophage cell line, RAW264.7 is not mediated by a decrease in TNF- $\alpha$ production. In addition, oral spermine administration suppresses intestinal iNOS expression, nitrotyrosine formation and the number of infiltrating macrophages and neutrophils in this organ after LPS challenge, suggesting a role for exogenous polyamines in inhibition of intestinal damage. Moreover, oral spermine administration also inhibits the increase in serum levels $\mathrm{NO}_{x}$ and the proinflammatory mediators IFN- $\gamma$ and enhances serum levels of the anti-inflammatory mediator IL-10, indicating a immunosuppressive role for intraluminally derived polyamines. In line with the results obtained in vitro, serum levels of TNF- $\alpha$ are unaffected after oral spermine administration. We hypothesize that oral polyamine administration might have therapeutic perspectives in several disorders characterized by systemic or intestinal inflammation.

In Chapter 10 we conclude that polyamines play an important role in the development of the intestinal immune system after birth. In addition, we suggest that polyamines 
and $\mathrm{NO}$ are involved in the physiological and inflammatory immune responses and in the non-specific host defence. Polyamines and NO both exert pro-inflammatory actions as well as anti-inflammatory actions, dependent on their concentration and localization. Although polyamines and NO have the same precursor, the regulation of their synthesis is a complex system that is controlled by a multitude of regulatory cytokines. In short, while the results from our studies provide further support for a central role for NO in the physiological and inflammatory immune response, the most prominent finding of this thesis is that exogenous and endogenous polyamines represent an equally important regulatory mechanism of these immune responses. Based on these findings it is conceivable that exogenous polyamines might have therapeutic effects during intestinal inflammation such as observed in coeliac disease and sepsis. 


\section{SAMENVATTTNG}

Het eerste gedeelte van Hoofdstuk 1 geeft een algemene beschrijving van polyamines en de pollyamine synthese. Polyamines zijn organische amines met een koolstof keten als basis. Alhoewel de exacte functie van deze amines nog niet geheel duidelijk is, is het wel bekend dat deze cellulaire componenten betrokken zijn bij veel verschillende cellulaire processen en essentieel zijn voor celdeling. In het tweede gedeelte van Hoofdstuk 1 wordt de belangrijke rol van polyamines in de ontwikkeling van de dunine darm mucosa en het mucosale immuunsysteem na de geboorte beschreven. Het feit dat remming van polyamine synthese in neonatale knaagdieren leidt tot een remming van de morfologische en biochemische ontwikkeling van de dunne darm geeft aan dat polyamine synthese essentieel is voor een normale ontwikkeling van de dunne darm na de geboorte.

Het bewijs dat polyamines essentieel zijn voor het in stand houden van de integriteit van de is geleverd door studies die aantonen dat inhibitie van polyamine synthese in de dunne darm resulteert in weefselschade. Bovendien is aangetoond dat aanwezigheid van verhoogde concentraties van polyamines in het darmlumen het herstel van darmschade stimuleert. Verder is een interessant gegeven dat polyamines indirect gevormd worden uit het aminozuur $\mathrm{L}$-arginine dat anderzijds tevens een precursor is voor de potente ontstekingsmediator NO. Vanuit dit perspectief beschrijft het derde gedeelte van Hoofdstuk 1 de rol van $\mathrm{NO}$ in de integriteit van de darm en in ontstekingsreacties in de darm. In tegenstelling tot het beschermende effect van polyamines, veroorzaakt een verhoogde productie van NO gedurende een ontstekingsreactie een toename in de permeabiliteit van de dunne darm. De functie van polyamines en $\mathrm{NO}$ gedurende ontstekingsreacties in de dunne darm zoals die optreden bij coeliakie en sepsis worden bediscussieerd.

Aan het einde van de introductie wordt de functie van polyamines in het immuunsysteem beschreven. Enerzijds zijn polyamines essentieel voor celdeling en spelen derhalve een belangrijke rol tijdens celactivatie en proliferatie als reactie op mitogene stimuli. Anderzijds wordt gesuggereerd dat de hoge concentraties van polyamines zoals die gevonden worden in tumoren en foetaal weefsel verantwoordelijk zijn voor het uitblijven van een immunologische afweerreactie tegen tumoren en de foetus. Deze suggestie wordt verder ondersteund door de observatie dat inhibitie van polyamine synthese in tumor dragende muizen de immunologische afweerreactie tegen de tumor doet toenemen. Tenslotte wordt de rol van polyamine oxidase activiteit in relatie met tot immunosuppressieve effecten van polyamines beschreven.

Hoofdstuk 2 beschrijt een studie naar de normale ontwikkeling van het fenotype van intra-epitheliale lymfocyten (IEL) en lamina propria lymfocyten (LPL) in de dunne darm van de muis na de geboorte. Terwijl de toename van het aantal LPL plaats vindt voor dag 15 na de geboorte, neemt het aantal IEL pas toe na dag 15. Wanneer de 
dieren gespeend worden op dag 21 na de geboorte (dat wil zeggen van de moeder vandaan gehaald worden) eten ze alleen nog vast voedsel. Rondom het spenen verandert het expressie patroon van celmembraan antigenen van zowel IEL als LPL in het mature fenotype van deze lymfocyten. Verder is opvallend dat het aantal thymusonafhankelijke IEL, welke TCR $\gamma \delta$ tot expressie brengen (TCR $\gamma \delta \delta^{*}$ IEL), eerder toeneemt dan het aantal thymus-afhankelijke TCR $\alpha B^{+}$IEL. De toename van het aantal TCR $\alpha \beta^{+}$IEL wordt vooral gestimuleerd door de verandering van voedsel na het spenen. Samenvattend laat deze studie zien dat het mucosale immunsysteem in de dunne darm van de muis zich ontwikkelt gedurende de eerste drie weken na de geboorte, en dat na het spenen het fenotype van IEL en LPL overeenkomt met het fenotype van deze cellen in volwassen muizen.

In Hoofdstuk 3 wordt aangetoond dat exogene polyamines een rol spelen in zowel de ontwikkeling van het mucosale immuunsysteem van de dunne darm als ook in de biochemische rijping van de enterocyten. Orale toediening van het polyamine spermine aan muizen van 12 dagen oud resulteert in een toename van het aantal IEL dat TCR $\alpha \beta, C D 4$ en $C D 5$ tot expressie brengt, overeenkomend met het fenotype van de thymus-afhankelijke IEL. Toediening van spermine heeft geen effect op het aantal of het fenotype van de LPL. Aangezien het effect van spermine op IEL alleen optreedt als er biochemische rijping van de enterocyten plaats vindt, wordt geconcludeerd dat het effect van spermine op de fenotypische ontwikkeling van de IEL mogelijk gemediëerd wordt via de inductie van biochemische maturatie van de enterocyten.

In Hoofdstuk 4 wordt de ontwikkeling van een ELISA voor het bepalen van nitrotyrosine in humaan plasma beschreven. De reactie tussen NO en superoxide anion resulteert in peroxynitriet. Nitrotyrosine is een stabiel eindproduct van de reactie van peroxynitriet met tyrosine residuen. Tot nu toe werden serum levels van de NOoxidatie producten $\left(\mathrm{NO}_{\mathrm{x}}\right)$ nitraat en nitriet worden gebruikt al maat voor de hoeveetheid geproduceerd $\mathrm{NO}$. Echter serum $\mathrm{NO}_{\mathrm{x}}$ heeft een relatief korte halfwaardetijd in de circulatie hebben. Daarbij komt dat NO-toxiciteit het gevolg van de vorming van de sterke oxidant peroxynitriet resulterend nitrotyrosine vorming en niet van $\mathrm{NO}_{x}$ zelf. Aangezien de meeste (genitreerde) plasma eiwitten een langere halfwaarde tijd hebben dan $\mathrm{NO}_{x}$ zouden plasma nitrotyrosine levels een mogelijk stabielere marker zijn voor $\mathrm{NO}$-gemediëerde schade dan plasma $\mathrm{NO}_{x}$ concentraties. In dit hoofdstuk wordt tevens aangetoond dat de concentraties van zowel nitrotyrosine als $\mathrm{NO}_{\mathrm{x}}$ sterk zijn toegenomen in plasma van kinderen met actieve coeliakie. Nitrotyrosine en $\mathrm{NO}_{\mathrm{x}}$ concentraties nemen af als deze kinderen een gluten vrij dieet krijgen. Deze resultaten suggereren een relatie tussen de ontsteking in de dunne darm en een toename van plasma nitrotyrosine en $\mathrm{NO}_{\mathrm{x}}$ concentraties.

In Hoofdstuk 5 wordt de betrokkenheid van $\mathrm{NO}$ in de pathofysiologie van darm ontsteking bevestigd door immunohistochemische kleuring van iNOS en nitrotyrosine 
in duodenum biopten van patiënten met actieve coeliakie. Induceerbaar NOS en nitrotyrosine komen duidelijk tot expressie in het epitheel van de crypten, hetgeen duidt op de vorming van peroxynitriet leidend tot de nitratie van cellulaire eiwitten. Tevens wordt aangetoond dat het totale aantal macrofagen in de darm is toegenomen, met name het aantal infiltrerende macrofagen, die in tegen stelling tot residente darm macrofagen CDI4 tot expressie brengen. De in deze studie gevonden co-expressie van iNOS met CDI4 suggereert een rol voor de infiltrerende macrofagen in de pathofysiologie van coeliakie.

In Hoofdstuk 6 wordt de rol van de endogene cytokinen TNF- $\alpha$, IFN- $\gamma$ en IL-10 in NO productie in vivo onderzocht in een sepsis model in de muis. Terwijl het blokkeren van hetzij endogeen TNF- $\alpha$ of hetzij IFN- $\gamma$ geen effect heeft op de concentratie van $\mathrm{NO}_{K}$ in de circulatie na i.p. toediening van LPS, resulteert het gelijktijdig inactiveren van beide ontstekingsmediatoren in een zeer sterke afname van de LPS-geinduceerde $\mathrm{NO}_{x}$ concentraties. Deze bevindingen duiden erop dat LPS NO productie induceert via zowel TNF- $\alpha$ als IFN- $\gamma$. Tevens wordt in deze studie enerzijds aangetoond dat IL-10 betrokken is bij de inhibitie van LPS-gestimuleerde NO productie remming van TNF- $\alpha$ en IFN- $\gamma$ productie, terwijl anderzijds de resultaten van de gecombineerde behandeling van anti-IL- 10 met anti-TNF- $\alpha$ of anti-IFN- $\gamma$ aantonen dat IL-10 tevens betrokken is bij de inductie van NO productie na LPS stimulatie.

In Hoofdstuk 7 wordt aangetoond dat de dunne darm, de long en het hart de belangrijkste organen zijn die betrokken zijn bij de toename in NO productie na LPS stimulatie. Tevens wordt gedemonstreerd dat TNF- $\alpha$, IFN- $\gamma$ en IL-10 betrokken zijn bij de regulatie van iNOS expressie in deze organen. Terwijl de aanwezigheid van TNF- $\alpha$ of IFN- $\gamma$ essentieel is voor iNOS expressie na LPS stimulatie, is IL-10 via inhibitie van TNF- $\alpha$ en IFN- $\gamma$ betrokken bij de onderdrukking van iNOS expressie in deze organen. De resultaten van de gecombineerde behandeling met anti-IL-10 en anti-TNF- $\alpha$ of anti-IFN- $\gamma$ tonen daarentegen aan dat IL-10 mogelijkerwijs ook betrokken is bij de inductie van iNOS expressie na LPS stimulatie.

In Hoofdstuk 8 worden de effecten van de polyamines cadaverine, putrescine, spermidine en spermine op de cytokine productie van humane PBMCs en gezuiverde monocyten in vitro bestudeerd. Polyamines zelf hebben noch effect op de basale cytokine productie noch op de LPS- of PHA-gestimuleerde cytokine productie. Echter, in de aanwezigheid van polyamine oxidase activiteit worden spermine en spermidine geoxideerd tot producten die afhankelijk van hun concentratie proinflammatoire dan wel anti-inflammatoire effecten kunnen hebben. In lage concentraties stimuleren deze oxidatie producten cytokine productie en oefenen daarmee pro-inflammatoire effecten uit, terwijl ze in hoge concentraties de cytokine productie remmen en dus anti-inflammatoir werken. Afname van de cytokine 
productie gaat vergezeld van een toename in het aantal dode cellen, wat impliceert dat de gevormde polyamine oxidatie producten toxisch zijn voor humane PBMCs en monocyten.

In Hoofdstuk 9 wordt aangetoond dat exogene polyamines zowel in vitro als in vivo LPS-gestimuleerde NO productie remmen. De afname van de LPS-gestimuleerde NO productie in een muizen macrofagen cellijn door spermine is niet het resultaat van een afname in TNF- $\alpha$ productie. Tevens wordt gedemonstreerd dat orale toediening van spermine aan LPS-gestimuleerde muizen resulteert in een afname van iNOS en nitrotyrosine expressie en het aantal infiltrerende macrofagen en neutrofielen in de dunne darm van deze dieren. Deze resultaten suggereren een mogelijke rol van exogene polyamines in de beperking van inflammatoire darmschade. Bovendien leidt het oraal toedienen van spermine in deze dieren ook tot een afname in serum concentraties van $\mathrm{NO}_{x}$ en van de ontstekingsmediator IFN- $\gamma$, en in een toename in de serum concentratie van het anti-inflammatoire cytokine IL-10, hetgeen een immunosuppressieve werking van polyamines afkomstig uit het darm lumen doet vermoeden.

In Hoofdstuk 10 stellen we dat polyamines een belangrijke rol spelen bij de ontwikkeling van het immuunsysteem van de darm na de geboorte. Verder wordt er geconcludeerd dat zowel polyamines als NO betrokken zijn bij de normale fysiologische immuunreactie, ontstekingsreactie en de niet-specifieke afweerreactie. Polyamines en NO bezitten beide pro-inflammatoire en anti-inflammatoire eigenschappen afhankelijk van hun concentratie en lokalisatie. Alhoewel polyamines en NO dezelfde precursor hebben, is de regulatie van hun productie een complex systeem, dat beïnvloed wordt door een verscheidenheid aan regulatoire cytokines. Samenvattend, terwijl de studies gepresenteerd in dit proefschrift een centrale rol voor NO in de fysiologische immuunreactie en ontstekingsreactie ondersteunen, is de belangrijkste nieuwe bevinding van dit proefschrift dat exogene en endogene polyamines een evenzeer belangrijke rol spelen in de regulatie van immuunreacties. Op grond van deze resultaten is het aannemelijk dat exogene polyamines een therapeutisch effect kunnen hebben bij bepaalde intestinale ontstekingsreacties als gevolg van voedsel allergie of tijdens sepsis. 
$-198$. 


\section{DANKWOORD}

Toen i $\mathrm{k}$ in Maastricht werd aangenomen als A.I.O. wist ik niet goed wat me te wachten stond en wat promoveren werkelijk inhield. Maar welke A.I.O. weet dat wel, in ieder geval zag ik het als een uitdaging om het er hier in het zuiden des lands er goed vanaf te brengen. En ziedaar nu ligt er een proefschrift. In de eerste plaats dank ik mijn ouders, Gert-Jan en Marijke, voor hun niet aflatende steun en hun vertrouwen in de keuzes die ik maak en de dingen die ik doe. Het feit dat ik weet dat er altiji een thuisfront is om op terug te vallen heeft me gemaakt tot wie ik nu ben en daarom draag ik dit proefschrift aan jullie op.

Professor Donckerwolcke wil ik bedanken voor zijn bereidheid als mijn promotor op te treden. De leden van de Beoordelingscommissie, de Professores Büller, Soeters, Stockbrugger en Wouters, ben ik zeer erkentelijk voor het feit dat zij dit proefschrift wilde lezen en beoordelen. Further, I would like to thank Professor Dandrifosse for critically reviewing my thesis.

Zoals well bekend, doe je onderzoek niet alleen en als A.I.O. al helemaal niet zonder begeleiding. Mijn beide co-promotores Dr. W.A. Buurman en Dr. P.Ph. Forget hebben deze taak op zich genomen. Beste Wim, weer een A.I.O. afgeleverd. Al liep het niet altijd even soepel, denk ik dat het eindresultaat er toch mag wezen en dat heb ik voor een groot deel toch aan jou te danken. Beste Dr. Forget, uw enthousiasme voor het onderzoek en de resultaten was altijd erg motiverend. Ik hoop dat het gastroenterologisch onderzoek bij de vakgroep Kindergeneeskunde voortgezet kan worden.

Natuurlijk is ook de atmosfeer op de werkvloer van belang voor het verkrijgen van goede resultaten. Ik heb de afgelopen jaren met veel plezier gewerkt op het Laboratorium Algemene Heelkunde. Ook al is de samenstelling in de afgelopen jaren erg veranderd de sfeer was uitstekend, bedankt Anita, Bas, Berry, Brigitte, Carlo, Daniëlle, David, Dennis, François, Gabrie, Gaby, Hans, Isabelle, Isolde, Ivo, Jeske, Jet, Joffrey, Joris, Juanita, Judith, Kees, Maaike, Maarten, Marc D, Marc N, Marcella, Marian, Mart-Jan, Martijn, Mieke, Mick, Mickey, Monique, Nicole, Ralph, Robert Kees, Sandra, Sen, Shirley, Steven, Tim, Trudi en Vincent. De collegialiteit, betrokkenheid, lab-uitjes, sinterklaasavonden en dergelijke zijn van wezenlijk belang geweest voor mijn plezier in het werk.

Beste Monique, het klikte gelijk tussen ons. We hebben heel wat tijd samen doorgebracht zowel op het werk als daarbuiten. Je hebt zeker niet alleen in wetenschappelijke zin aan dit proefschrift bijgedragen. Ik ben dan ook blij dat je mijn paranimf wil zijn. 
Beste Francie, dezelfde middelbare school, dezelfde studie en nu straks ook allebei gepromoveerd en aan het werk als post-doc. Een vriendin voor het leven die meestal precies weet wat je bedoelt.

Tevens dank ik het C.P.V, met name Frans Weekers, voor de goede zorgen van de (baby)muizen en het uitleggen hoe je een 5 dagen oude muis iets oraal kan toedienen. En Geertjan van Zonneveld van de A.V. dienst voor zijn geduld en tijd voor het inscannen van de niet altijd even scherpe dia's voor foto composities voor een artikel.

Tenslotte maar zeker niet op de laatste plaats, lieve Maarten, hoe kan ik nu in een enkele zin duidelijk te maken wat je voor mij betekent. Je wist als geen ander hoe het was om het boekje echt af te krijgen. Jouw relativeringsvermogen en vele suggesties, vooral met betrekking tot de Engelse taal, zorgde ervoor dat ik mijn onzekerheid de baas bleef. Laat de toekomst zonder het werken en denken aan boekjes maar komen, ik ben er klaar voor ... 


\section{LIST OF PUBLICATIONS}

\section{Papers presented in this thesis}

1. Ter Steege ICA, Buurman WA, Forget PPh. Development of the mucosal immune system in neonatal mice. Dev Immunol 5: 121-128, 1997.

2. Ter Steege JCA, Buurman WA, Forget PPh. Spermine induces precocious maturation of the mucosal immune system in neonatal mice. I Pediatr Gastroenterol Nur 25: 332-340, 1997.

3. Ter Steege JCA, Buurman WA, Arends JW, Forget PPh. Presence of inducible nitric oxide synthase, nitrotyrosine, CD68 and CD14 in the small intestine in celiac disease. Lab Invest 77: $29-36,1997$.

4. Ter Steege JCA, Van de Ven WCM, Forget PPh, Bumman WA. Role of endogenous TNF $\alpha$, IFN $\gamma$ and IL 10 in LPS-induced NO release in mice. Cytokine 10: 115-123, 1998.

5. Ter Steege ICA, Van de Ven WCM, Forget PPh, Buurnan WA. Regulation of LPSinduced iNOS expression in the major organs in a mouse model. Role of endogenous IFN$\gamma$, TNF- $\alpha$ and IL-10. Submitted.

6. Ter Steege JCA, Forget PPh, Buurman WA. Anti-inflammatory actions of polyamines are mediated by polyamine oxidase and are related with cytotoxicity. Submitted.

7. Ter Steege JCA, Koster-Kamphuis L, van Straaten EA, Forget PPh, Buuman WA. Nitrotyrosine in plasma of coeliac disease patients as detected by a new sandwich ELISA. Free Radical Biol Med, in press.

8. Ter Steege JCA, Forget PPh, Buurman WA. Oral spermine administration inhibits NOmediated intestinal damage and levels of inflammatory mediators in a mouse endotoxin model. Shock, in press.

\section{Other papers}

1. Arosa FA, Da Silva AJ, Godinho IM, Ter Steege JCA, Porto G, Rudd CE, De Sousa M.Decreased CD8-p56lck activity in peripheral blood T-lymphocytes from patiens with hereditary haemochromatosis. Scand J Inmmol 39: 426-432, 1994.

\section{Abstracts and presentations}

1. Arosa FA, Da Silva AJ, Godinho IM, Ter Steege JC, Porto G, Rudd CE, De Sousa M. Decreased CD8-p56lck activity in peripheral blood T-lymphocytes from patients with hereditary haemochromatosis.

$12^{\text {thy }}$ European Immunology Meeting

14-17 juni 1994, Barcelona

2. Ter Steege JCA, Buurman WA, Forget PPh. Spermine induces precocious maturation of the mucosal immune system in neonatal mice.

(J Pediat Gastroenterol Nutr 20: 454, 1995)

European Society of Pediatric Gastroenterology and Nutrition

28 mei- 1 juni 1995, Jeruzalem 
3. Ter Steege JCA, Buurman WA, Forget PPh. Effect of spermine on the immature mucosal immune system in mice.

(Immunalogy 86(Suppl): 26, 1995)

Joint Congress of BSI and NVVI

6 - 8 december 1995, Brighton

4. Ter Steege JCA, Butrman WA, Arends JW, Forget PPh. Enhanced iNOS expression in small bowel tissue in coeliac disease.

(Nournal of Pediatric Gastroenterology and Nutrition 22: 443, 1996)

European Society of Pediatric Gastroenterology and Nutrition

6-9 juni 1996, München

5. Ter Steege JCA, Butrman WA, Arends JW, Forget PPh. Enhanced iNOS expression in small bowel tissue in coeliac disease.

(Tijdschrift wook Kindergeneeskunde Suppl 1:85, 1996)

Najaarsvergadering Nederlandse Vereniging voor Kindergeneeskunde

3-4 oktober 1996, Veldhoven

6. Ter Steege JCA, Buurman WA and Forget PPh. Effect of spermine on the immature mucosal immune system in mice.

(Immunology and Cell Biology Suppl 1: A49, 1997)

$9^{\text {th }}$ Intemational Congress of Mucosal Immunology

27 - 31 januari 1997, Sydney

7. Ter Steege JCA, Burman WA, Arends JW, and Forget PPh. Enhanced iNOS expression in coeliac disease biopsy tissue.

(Immunology and Cell Biology Suppl 1: A 133, 1997)

$9^{\text {th }}$ International Congress of Mucosal Immunology

27 - 31 januari 1997 , Sydney

8. Ter Steege JCA, Buurman WA, Arends JW, and Forget PPh. Inducible NO synthase, nitrotyrosine en CDI4-positieve macrofagen in darmbiopten van coeliakie patienten.

(Tijdschrift woor Kindergeneeskunde Suppl 1: 123, 1997)

Naigatsyergadering Nederlandse Vereniging von. Kinderganeshunde

5- 7 november 1997 , Veldhoven 


\section{CURRICULUM VITAE}

Jessica ter Steege werd op 17 februari 1969 geboren in Utrecht. Na het behalen van het VWO diploma aan het Niels Stensen College te Utrecht (1981-1987), startte zij in 1987 met de studie Biologie aan de Landbouw Universiteit Wageningen. In 1993 rondde zij haar studie af na het doorlopen van afstudeervakken bij de vakgroepen Celbiologie \& Immunologie en Virologie. In het kader van het afstuderen volgde zij stages bij het laboratorium experimentele patho-oncologie (LEPO) van de Daniel den Hoed Kliniek te Rotterdam en de Mestrado de Immunologia van ce Universidade do Porto te Portugal. Van september 1993 tot september 1997 was zij als assistent in opleiding (A.I.O.) bij de vakgroep Kindergeneeskunde van de Universiteit Maastricht werkzaam op het laboratorium van de vakgroep Algemene Heelkunde van deze Universiteit. Onder leiding van Dr. W.A. Buurman, immunoloog, en Dr. P.Ph. Forget, kindergastroenteroloog, werkte zij aan een onderzoeksproject getiteld, Effect van polyamines op de maturatie van het mucosale immunusysteem en de relatie met de ontwikkeling van orale tolerantie voor voedsel allergenen, dat werd gefinancierd door Nutricia Research en de Nutricia Research Foundation en dat heeft geleid tot dit proefschrift. Vanaf 1 september 1998 zal zij als post-doc werkzaam zijn bij de vakgroep Inwendige Geneeskunde, Afdeling Reumatologie en Klinische Immunologie van de Universiteit Utrecht. 